UNIVERSIDADE DE SÃO PAULO

INSTITUTO DE GEOCIÊNCIAS

\title{
DESCRIÇÃO DO MEIO FÍSICO DA FOLHA CAPÃO BONITO (SG-22-X-B- III), SE DE SÃO PAULO ATRAVÉS DE ANÁLISES GEOMORFOMÉTRICAS, SENSORIAMENTO REMOTO E MAPEAMENTO GEOLÓGICO
}

Renato dos Santos Neves Kahwage

Orientador: Prof. Dr. Carlos Henrique Grohmann de Carvalho

DISSERTAÇÃO DE MESTRADO

Programa de Pós-Graduação em Recursos Minerais e Hidrogeologia

São Paulo

2013 


\section{UNIVERSIDADE DE SÃO PAULO \\ INSTITUTO DE GEOCIÊNCIAS}

\section{“DESCRIÇÃO DO MEIO FÍSICO DA FOLHA CAPÃO BONITO (SG-22-X-B-III), SE DE SÃO PAULO ATRAVÉS DE ANÁLISES GEOMORFOMÉTRICAS, SENSORIAMENTO REMOTO E MAPEAMENTO GEOLOGICO"}

\section{RENATO DOS SANTOS NEVES KAHWAGE}

Orientador: Prof. Dr. Carlos Henrique Grohmann de Carvalho

DISSERTAÇÃO DE MESTRADO

COMISSÃO JULGADORA

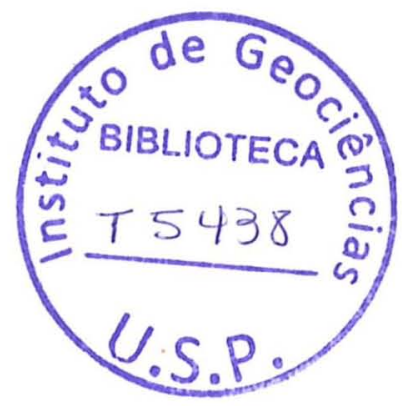

Nome

Assinatura

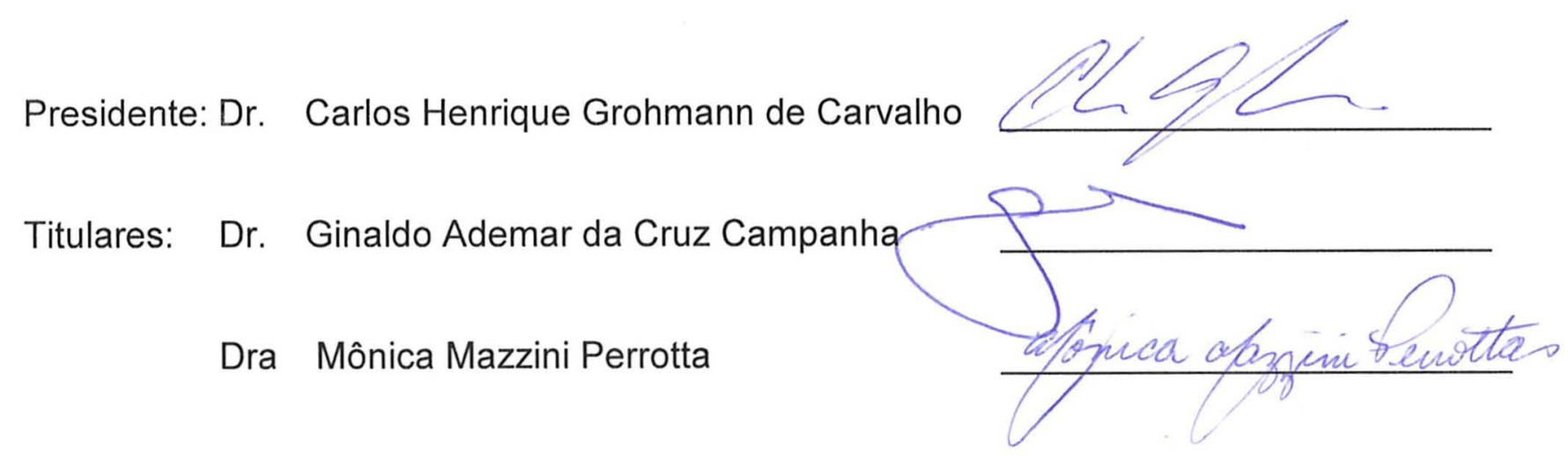



UNIVERSIDADE DE SÃO PAULO

INSTITUTO DE GEOCIÊNCIAS

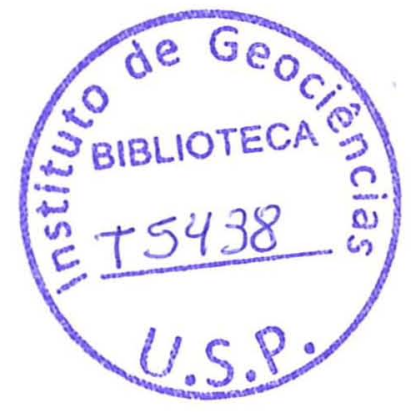

DESCRIÇÃO DO MEIO FÍSICO DA FOLHA CAPÃO BONITO (SG-22-X-BIII), SE DE SÃO PAULO ATRAVÉS DE ANÁLISES GEOMORFOMÉTRICAS, SENSORIAMENTO REMOTO E MAPEAMENTO GEOLÓGICO

\author{
Renato dos Santos Neves Kahwage
}

Orientador: Prof. Dr. Carlos Henrique Grohmann de Carvalho

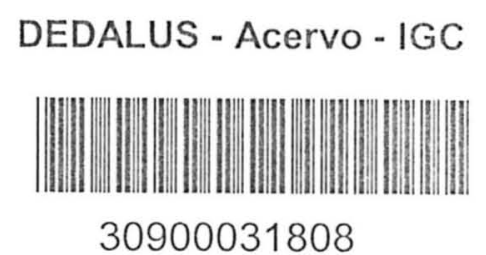

DISSERTAÇÃO DE MESTRADO

Programa de Pós-Graduação em Recursos Minerais e Hidrogeologia

São Paulo 


\section{Catalogação da Publicação \\ Serviço de Biblioteca \\ Instituto de Geociências da Universidade de São Paulo}

Kahwage, Renato dos S.N.

Descrição do meio físico da Folha Capão Bonito (SG-22-X-BIII), SE de São Paulo através de análises geomorfométricas, sensoriamento remoto e mapeamento geológico./ Renato dos Santos Neves Kahwage; orientador Carlos Henrique Grohmann. São Paulo, 2013.

163 Folhas: il. + 02 mapas 


\section{PREFÁCIO}

A geologia fornece àqueles que a escolheram como profissão a oportunidade entusiasmante de caminhar pelo mundo. As idas a campo trazem a quem está disposto a aprender, não só o conhecimento das rochas e das paisagens, mas também o conhecimento do povo, a cultura local e a experiência de vida.

Este trabalho me forneceu todas estas oportunidades. Conheci o Vale do Ribeira a fundo explorando sua geologia. Vislumbrei suas belezas - as paisagens bucólicas, as criações de búfalos, a mata atlântica em viço - mas também presenciei suas tristezas e sua inconcebível escassez de recursos, algo contrastante com tamanha riqueza natural.

Após sete anos estudando geologia, pela primeira vez posso afirmara que realmente conheço uma região. $E$ enquanto a descobria, percebi que chamar o trabalho que fazemos apenas de geologia é sem dúvida, um grande erro. É inaceitável que um profissional em geologia vá a campo e não conheça além das rochas abaixo de seus pés. Somos acima de tudo, cientistas da terra, este é o verdadeiro nome da profissão.

A grande diferença está no fato de que os cientistas da terra não se focam apenas em uma área, mas são profissionais multidisciplinares que buscam entender o meio como um todo, já que tudo na natureza é conectado. Sem dúvida, como geólogo de formação, busco entender o mundo em função das rochas. O importante, no entanto, é que não sejam negligenciados conhecimentos sobre a botânica e a biologia - tão dependentes das características do substrato - a geomorfologia - que, pasmem, muitas vezes é posta de lado por alguns geólogos - e até mesmo a geografia e a história - conhecimentos essenciais para se compreender a evolução do meio humano, ao qual integramos por condição de nascença.

Valendo-me da inter-relação tão básica entre todos os seres e a Terra e buscando compreender o meio ambiente de maneira mais ampla, propus este trabalho, realizado através de técnicas que levam em conta não somente as rochas, mas fatores relacionados à cobertura vegetal, ao estudo da paisagem e à utilização de sistemas computacionais para o desenvolvimento de mapas e análise de imagens. 
Nas páginas seguintes, serão expostas as características geomorfológicas da região entre as cidades de Capão Bonito e Sete Barras, bem como a descrição dos principais litotipos aflorantes. Este manuscrito contém ainda uma vasta revisão bibliográfica sobre a evolução do conhecimento geológico da área em questão, trazendo também algumas pinceladas sobre $\circ$ aspecto histórico-cultural da ocupação do Vale do Ribeira. Foram produzidos também dois mapas, um morfotectônico e um geológico, ambos se valendo da ajuda de sensores remotos para sua criação.

Por fim, esta tese apresenta um forte caráter didático no que diz respeito às técnicas de sensoriamento remoto empregadas, englobando a geobotânica, a fotointerpretação e utilização de dados digitais de altitude (Modelos digitais de Terreno - MDT) em geomorfometria. Neste trabalho elas serão bem detalhadas desde seus princípios físicos até sua parte prática.

Espero que este volume seja enriquecedor tanto para o leitor com o ensejo de conhecimentos básicos sobre técnicas de tratamento digital de dados para geologia, bem como para o profissional que busca uma base de dados atualizada e confiável sobre a região entre Capão Bonito e Sete Barras. Os últimos mapeamentos da área datam da década de 1980 e o presente trabalho conta, portanto, com a carta geológica mais atualizada e confiável da área, bem como um acervo digital de fotos das amostras de mão dos litotipos mais comuns encontrados na área. Além disto, traz ainda um detalhado mapa das feições morfológicas obtidas por fotointerpretação.

Espero por fim, que este trabalho venha a contribuir para futuras pesquisas nesta região que ainda carece de mapeamentos geológicos pormenorizados e que, sem sombra de dúvida, oferece um grande desafio para qualquer pesquisador. 


\section{AGRADECIMENTOS}

Agradeço primeiramente ao CNPq que através de uma bolsa CAPES, foi o principal financiador deste projeto.

Ao Programa de Recursos Minerais e Hidrogeologia, financiador da inscrição no Congresso Brasileiro de Geologia e no XVI Simpósio de Sensoriamento Remoto $\mathrm{XLVI}$, meus sinceros agradecimentos.

Agradeço ainda à CPRM, à qual me integrei para o trabalho de campo e em especial àqueles funcionários que trabalharam em equipe comigo para a realização deste mestrado: Frederico Meira Faleiros, Maurício Pavan Silva e Mônica Mazzini Perrota.

Aos professores cujas discussões e tutela em muito contribuíram para o crescimento tanto deste trabalho como do autor. Ao Prof. Dr. Cláudio Riccomini, ao Prof. Dr. Kenitiro Suguio e meus sinceros agradecimentos. Agradeço especialmente ao Prof. Dr. Carlos Henrique Grohmann que me orientou durante estes dois anos e meio, sempre apoiando minhas ideias e trazendo consigo todas as qualidades de um Grande Mestre.

Aos colegas de martelo e bússola que tanto me ajudaram a concluir esta tarefa, seja pelo enriquecimento de discussões ou simplesmente pelo companheirismo e amizade: Stephano Silva, Guilherme Guerra, Diego Daniel Silva, Victor Maurer, Luis Felipe Amade e tantos outros que fazem da geologia um verdadeiro lar, mas que não caberão aqui, um grande abraço.

À Andrea Prendália Harabari, minha mulher, companheira nas horas boas e ruins, meus agradecimentos e meu coração. Obrigado por tudo!

A todos os meus amigos alheios ao mundo das geociências, mas que de certa forma sempre contribuíram para o meu equilíbrio emocional e para a continuidade deste trabalho, meus sinceros agradecimentos. Entre vocês estão sem dúvida meus grandes amigos Felipe Najjar de Campos, Leandro Quaresma, Danilo Primi e André Ferreira Alves. A vocês, irmãos, um forte abraço do seu fiel amigo Renato. 

Finalmente, à minha família que sempre me apoiou. Aos meus queridos avós Natividade Barreiros dos Santos e José Francisco das Neves, que me acolheram desde o início de minha vida e que sempre foram uma fonte de carinho e de sabedoria inestimáveis, e que me transmitiram valores tão importantes para minha vida. Um beijo no coração de vocês. Às minhas irmãs, Beatriz e Maria Carolina, pela ternura, amizade e cumplicidade. Em especial, agradeço aos meus pais, Maria do Carmo dos Santos Neves Kahwage e Nagem Moura Kahwage, profundos entusiastas do conhecimento e grandes provedores, os quais sempre apostaram que seu filho de alguma forma, chegaria lá. A eles, os mais humildes agradecimentos e a eterna gratidão de um filho. 


\section{Conteúdo}

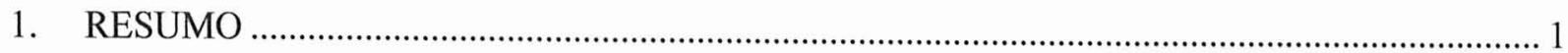

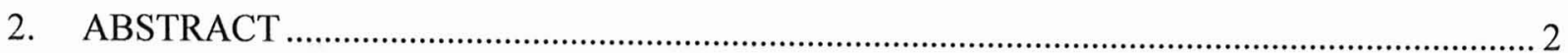

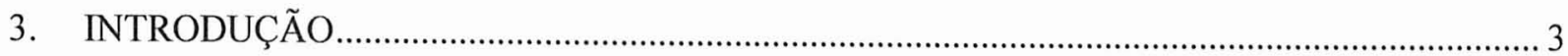

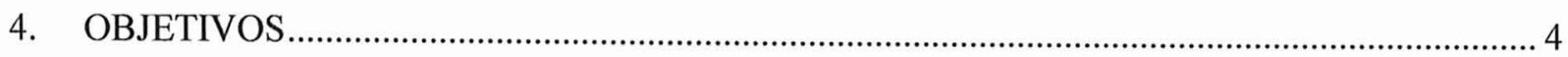

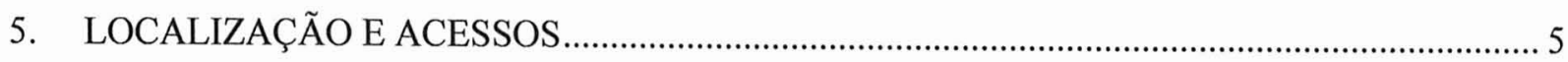

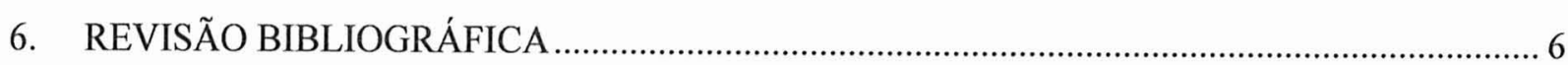

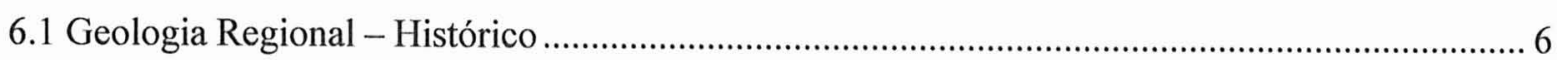

6.2 Geologia Regional -Compartimentação Tectônica da Faixa Apiaí-Ribeira ................................. 13

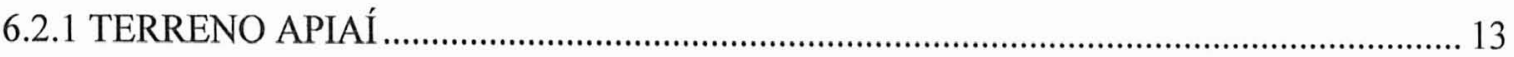

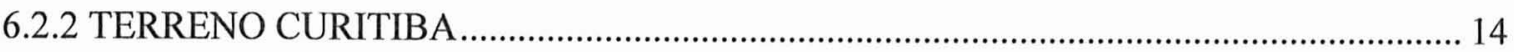

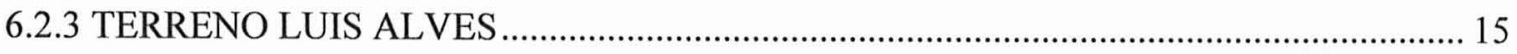

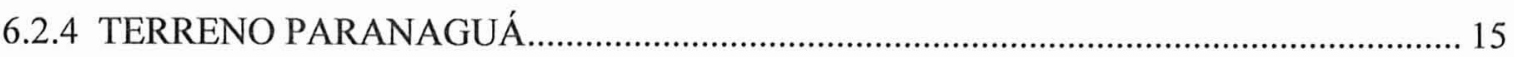

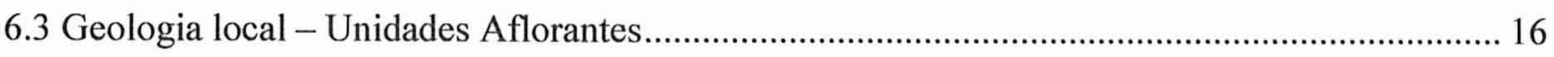

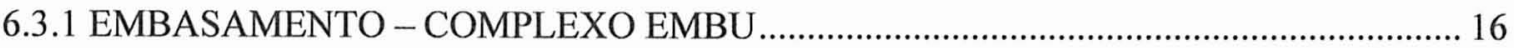

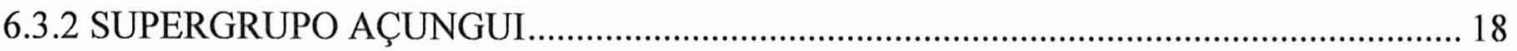

6.3.3 INTRUSÕES GRANÍTICAS NEOPROTEROZÓICAS ...................................................... 22

6.3.4 SEDIMENTAÇÃO PALEOZÓICA - BACIA DO PARANÁ …............................................. 23

6.3.5 A SEDIMENTAÇÃO TERCIÁRIA - QUATERNÁRIA …................................................. 23

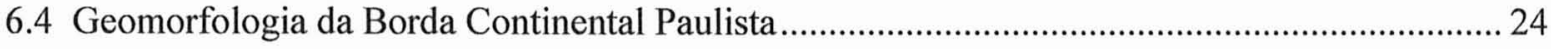

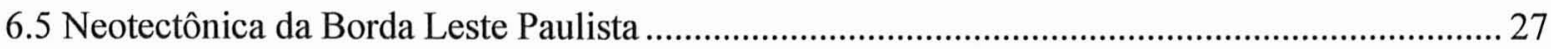

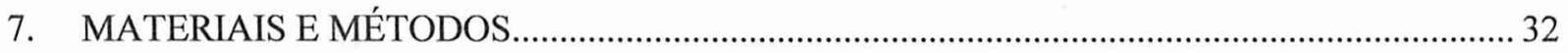

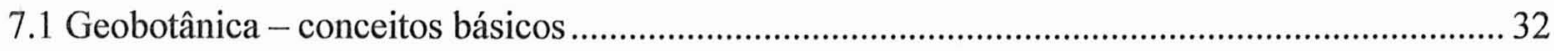

7.1.1 Processamento digital de imagens - capão bonito …………................................................... 38

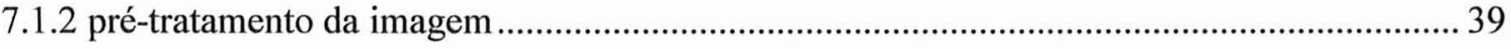

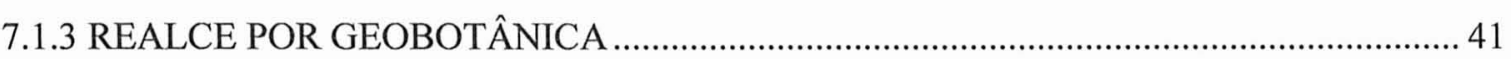

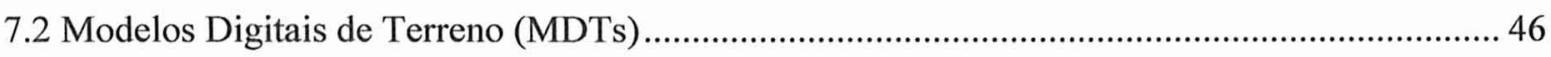

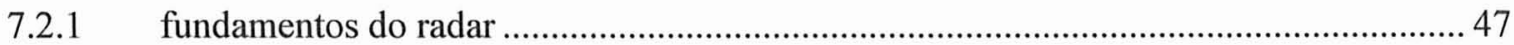

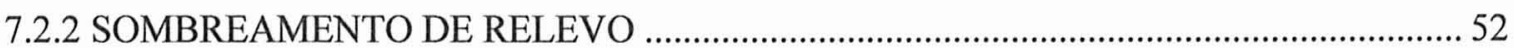

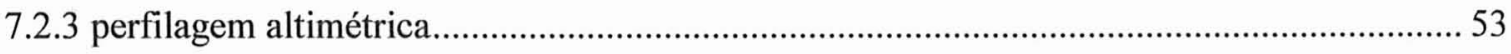

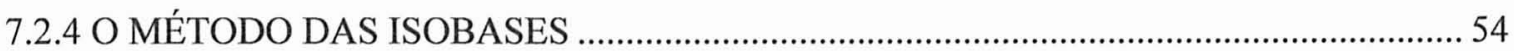

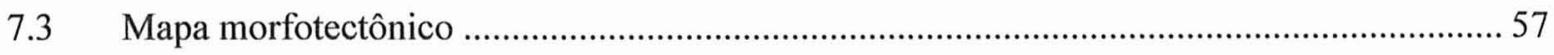

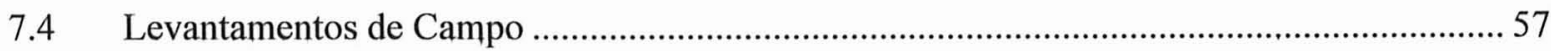

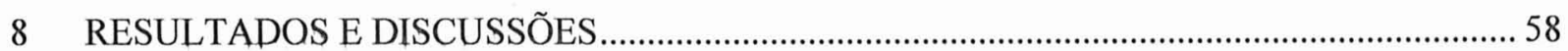

8.1 Geobotânica em imagens multiespectrais .............................................................................. 59 


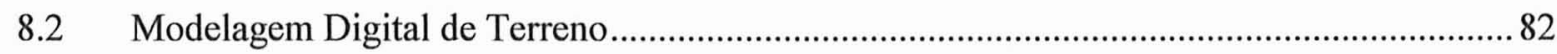

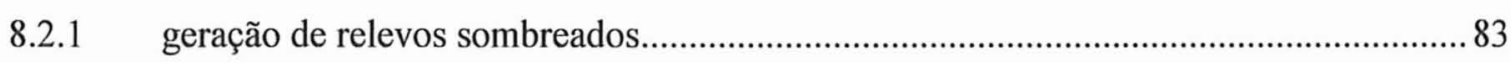

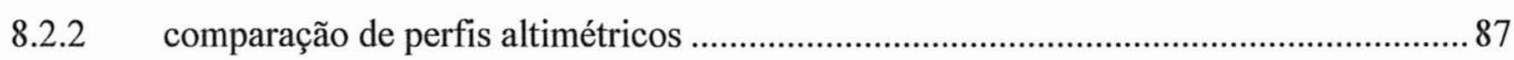

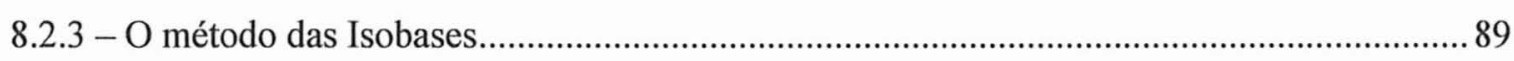

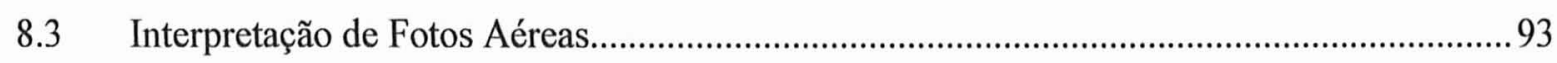

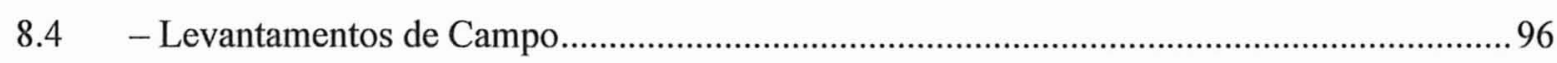

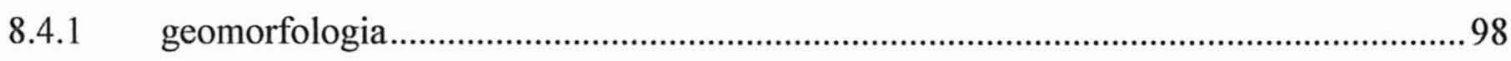

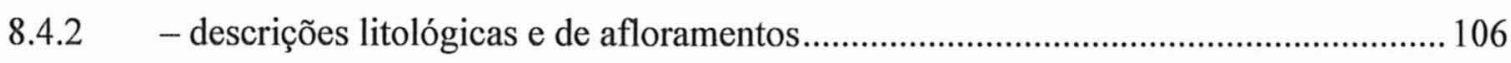

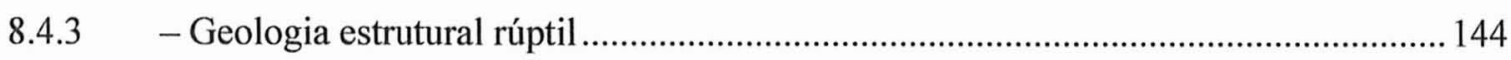

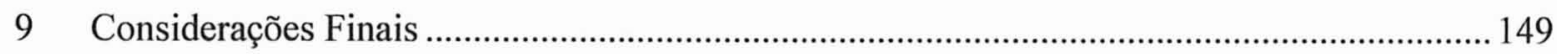

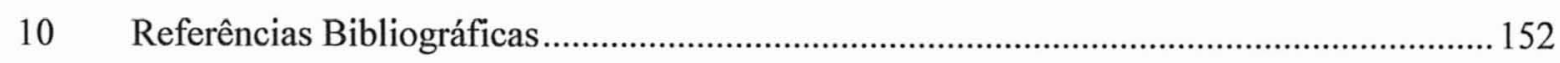

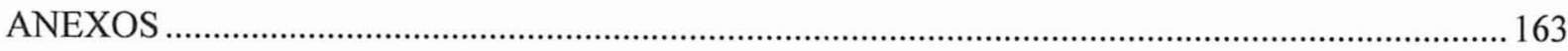




\section{RESUMO}

A região da Folha Capão Bonito (SB-22-X-B-III) apresenta uma ampla variedade geomorfológica e geológica, podendo ser dividida em quatro faixas de diferentes contextos geomorfológicose litológicos.

A norte, há morros suaves e planaltos da Bacia do Paraná, onde predominam siltitos finamente laminados do Grupo Itararé. Imediatamente a sul, há uma faixa de metassedimentos de direção NE-SW, o Supergrupo Açungui, de idade mesoproterozóica. Sustentando a Serra de Paranapiacaba (Serra do Mar), existe um batólito granítico de idade neoproterozóica, o Batólito de Agudos Grandes. Nas terras baixas no extremo sudeste da área, ocorrem os sedimentos terciários (Graben de Sete Barras) e quaternários (sedimentação atual do rio Ribeira de Iguape).

Este trabalho abordou de maneira descritiva os diferentes domínios presentes na área de estudo. Para tanto, se valeu não só da geologia de campo, mas principalmente de recursos computacionais tais como a geomorfometria - técnicas da extração de lineamentos, da comparação de perfis, e das isobases - e o sensoriamento remoto óptico - geobotânica das áreas vegetadas.

O estudo da geomorfologia em conjunto com o mapeamento geológico da região demonstrou que grande parte da morfodinâmica da área é controlada pela interação de duas principais estruturas geológicas: as zonas de cisalhamento regional e as foliaçōes metamórficas que compartilham o direcionamento NE-SW, além das fraturas associadas ao Alinhamento de Guapiara, este de direção NW-SE, perpendicular.

A relação de perpendicularidade entre estas estruturas, somada aos altos mergulhos de grande parte das litologias facilitam a geração de blocos de falhas normais. Estas seriam as responsáveis por desenvolver, através de sucessivos eventos neotectônicos, um espigão de direção NE-SW escalonado em patamares que vão desde depressões costeiras (Graben de Cananéia, Graben de Sete Barras) até o atual Planalto Atlântico, configurando o grande acidente geográfico do Sudeste do Brasil: a Serra do Mar. 


\section{ABSTRACT}

This work was made in an area at the southeastern portion of São Paulo State, SE Brazil, between the cities of Capão Bonito and Sete Barras. This region presents a great geomorphological and geological variety, and it can be divided into four regions with very distinct geomorphological and litological contexts.

To the north, there are gentle hills and plateaus of the Paraná Basin, dominated by finely laminated siltstones of the Itarare Group. Immediately to the south, there is a range of metasediments in the NE-SW, the Açungui Supergroup, of Mesoproterozoic age. Sustaining the Paranapiacaba Range (Serra do Mar), there is a granite batholith of Neoproterozoic age, the Agudos Grandes intrusion. Lowlands in the southeast end of the area is the region where the Tertiary (Graben de Sete Barras) and Quaternary (recent alluvial sediments from the Ribeira river flood plains) sediments occur.

This work addressed to describe all the different domains present at the study area. Thus, not only the field geology was used, but mostly computational resources such as geomorphometry - techniques of of lineaments mapping, the comparison of altitude profiles, and isobases - and optical remote sensing - Geobotanic of vegetated areas.

The geomorphology studies in conjunction with the geological mapping of the region has shown that much of the morphodynamics of the area is controlled by the interaction of two main geological structures: shear zones and regional metamorphic foliation, both sharing the NE-SW direction, and fractures associated to the Guapiara Alignment, with NW-SE direction.

The perpendicularity between these structures, coupled with the high dips of most lithologies supports the generation of normal fault blocks. These gravitational faults would be responsible for developing, through successive neotectonic events, a range stretched at the NE-SW direction, staggered at levels ranging from coastal depressions (Cananéia Graben, Sete Barras Graben) until the high Atlantic Plateau, setting the major landform of southeastern Brazil: the Serra do Mar Range. 


\section{INTRODUÇÃO}

O Vale do rio Ribeira, região situada a SE do Estado de São Paulo, tem sido alvo de amplas pesquisas e discussões geológicas desde o século XIX. O interesse pela região se deve principalmente à grande quantidade de ocorrências minerais associadas às rochas da Faixa Apiaí-Ribeira e suas intrusivas, notavelmente $\mathrm{Au}, \mathrm{Fe}$, $\mathrm{Pb}$ e $\mathrm{Ag}$.

Apesar de contar com um dos potenciais prospectivos mais elevados do Estado, a região ainda carece de mapeamentos geológicos em escala apropriada. Em grande parte, a falta de dados geológicos na região é oriunda das dificuldades de trabalho em uma área que apresenta relevo muito acidentado, além de densa cobertura vegetal e acessos precários. Neste contexto, a CPRM - Companhia de Pesquisa de Recursos Minerais - vem se esforçando para realizar os mapeamentos em escala 1:100.000 do Vale do Ribeira, contribuindo assim para o melhor conhecimento geológico do local. Desta forma, foi proposta uma parceria técnicoacadêmica entre a equipe de mapeamento da folha Capão Bonito (SG-22-X-B-III) e o presente autor, para a realização deste estudo.

As dificuldades de trabalho acima mencionadas servem de incentivo para a utilização de ferramentas de sensoriamento remoto e computação geológica como contribuição para o mapeamento litoestrutural da área, diminuindo as idas a campo e complementando o trabalho da geologia clássica.

Neste volume, serão abordadas técnicas de tratamento de modelos digitais de terreno buscando o entendimento das litoestruturas da área da folha Capão Bonito, bem como o estudo dos movimentos neotectônicos gerais, através da técnica das isobases e de análises estruturais de campo. Serão ainda apresentadas composições coloridas em falsa cor de imagens de satélite tratadas por geobotânica - ferramenta que gerou resultados que em muito contribuíram para a interpretação geológica da área. 


\section{OBJETIVOS}

O presente trabalho foca o estudo geológico, geomorfológico e da evolução da paisagem da região da folha Capão Bonito, a SE do estado de São Paulo, através da utilização de sensores remotos, plataformas computacionais SIG (Sistema de Informações Geográficas) e mapeamento.

Por ser uma área vasta - cerca de $3.000 \mathrm{~km}^{2}$ - a observação remota tornou-se peça-chave para a realização deste estudo. Foram utilizados produtos de todos os tipos de sensores disponíveis, entre ativos (SRTM - Shuttle Radar Topography Mission) e passivos (TM do satélite Landsat5 e câmeras aeroportadas).

Estes dados de sensores remotos foram tratados, segundo sua natureza, por diferentes processos. Dados de RADAR como o SRTM foram utilizados de maneira a obter informações inerentes ao formato do relevo, bem como serviram de base para aplicação de técnicas computacionais como a das isobases. Dos resultados provenientes deste tipo de dados, foram obtidas informações importantes relacionadas à geomorfometria e à geologia estrutural rúptil como condicionante de relevo.

Dados de sensores ópticos, por sua vez, foram tratados através da geobotânica, técnica que engloba uma série de filtragens matriciais e processos estatísticos de imagem. Cerca de dois terços da área de estudo consistem de mata atlântica preservada, o que possibilitou a utilização deste tratamento com bastante eficácia.

Os dados obtidos por sensores remotos foram corroborados por levantamentos de campo realizados em novembro de 2011 e maio de 2012, utilizando-se de geologia clássica - levantamento de medidas de planos de fraturas e falhas com bússola, coleta de amostras e mapeamento. 


\section{LOCALIZAÇÃO E ACESSOS}

A área de estudo (Figura 1) engloba a cidade de Capão Bonito, distante $230 \mathrm{~km}$ da capital paulista e situada na região Sudeste do Estado de São Paulo, entre as cidades de São Miguel Arcanjo e Guapiara. O acesso pode ser realizado pela rodovia Raposo Tavares SP-270 ou pela rodovia Castello Branco SP-280, saindo em direção a Tatuí pela rodovia SP-129, logo após Boituva. Depois de Tatuí, segue-se em direção a Capão Bonito pela rodovia SP-127.

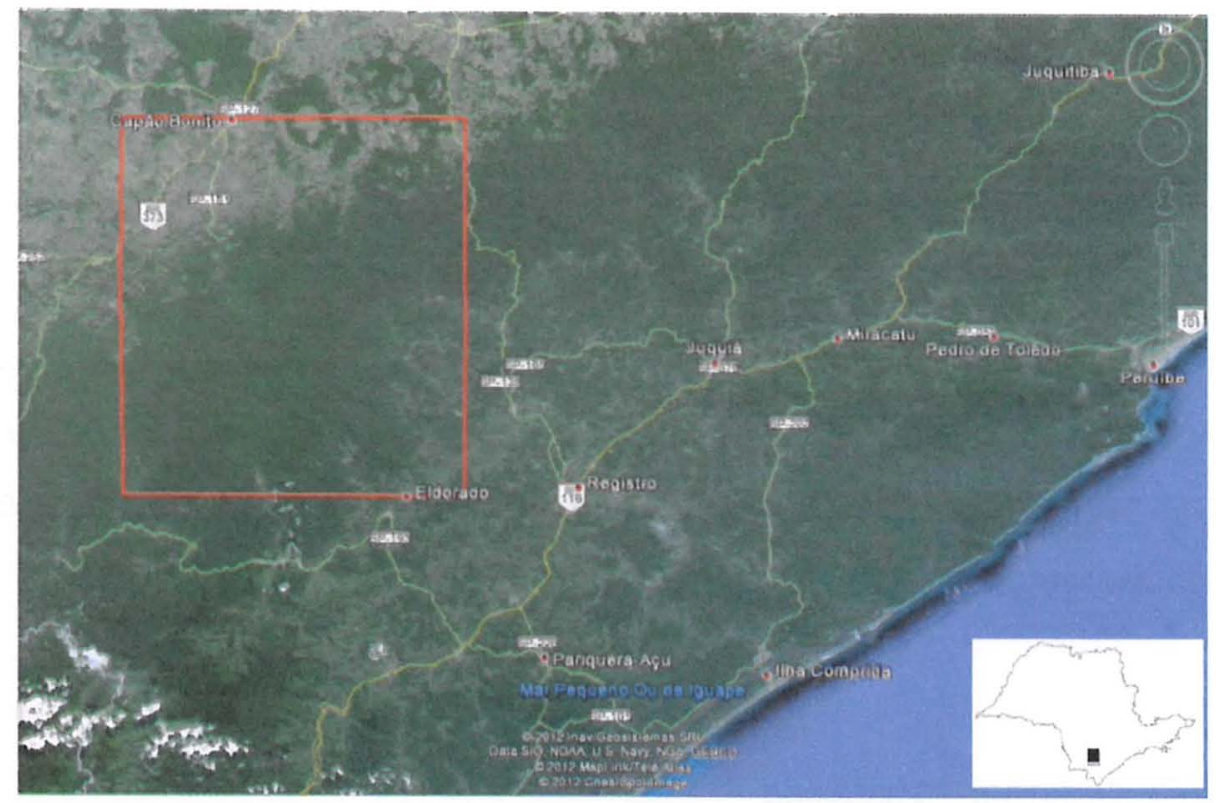

Figura 1. Localização da folha 1:100.000 Capão Bonito SG-22-X-B-III, a SE do Estado de São Paulo (Imagem Google Earth)

A cidade de Capão Bonito situa-se no Vale do Alto Paranapanema, possui altitude em torno dos 700 metros e uma população de cerca de 46 mil habitantes. Segundo Saia (2006), o clima predominante é o subtropical de altitude, com alta pluviosidade no verão, sem inverno seco, com chuvas se estendendo por todo o ano. Os valores de precipitação são de 1200 a 1500 mm/ano, e temperaturas com médias de $15^{\circ} \mathrm{C}$ no inverno e $22^{\circ} \mathrm{C}$ no verão.

A maior parte da área de estudo, no entanto, se situa na Serra de Paranapiacaba, região protegida pelo Contínuo Ecológico de Paranapiacaba - união dos parques Intervales, PETAR, Parque Estadual Carlos Botelho e Estação Ecológica de Xitué, perfazendo cerca de 120.000 hectares de terras protegidas e o 
segundo maior corredor de mata atlântica preservado no Estado de São Paulo, somente inferior em área ao Parque Estadual da Serra do Mar (Fundação Florestal 2010).

Os tipos de vegetação encontrados na região da serra são principalmente a floresta ombrófila mista e a mata de araucárias, nas porções de altitude mais elevada. Na porção norte do Parque Intervales, ocorre uma zona de confluência de domínios florestais com florestas ombrófilas densas, mistas e estacionais semideciduas (Fundação Florestal 2010).

\section{REVISÃO BIBLIOGRÁFICA}

A revisão bibliográfica do trabalho abordará três tópicos principais: a geologia regional -particionada em um breve histórico, um tópico sobre a divisão tectônica da área e uma parte descritiva das unidades aflorantes- a geomorfologia da área de estudo, e a neotectônica do SE do Brasil.

\subsection{Geologia Regional - Histórico}

Os primeiros estudos geológicos da borda atlântica e adjacências nos estados de São Paulo e Paraná datam do século XIX. Trabalhos pioneiros realizados por Andrada (1805) contêm citações sobre a geologia da área. O autor reconhece a existência de rochas graníticas e xistos em abundância na região, conforme o relatado enquanto subia o rio Açungui:

"[...]Quanto a observações mineralógicas, decorrendo as margens até perto do segundo salto, observei o seguinte: nos córregos nascentes dos morros... há os mesmos blocos da rocha granítica já mencionada e, nas faldas de um teso sobranceiro ao rio, pedaços de um barro muito ocráceo e talcoso, já com a natureza dos xistos[...]".

Andrada reconhece ainda a abundância de calcários na região de Iporanga, 
descreve feições cársticas e diversas ocorrências e antigas lavras de ouro, sobretudo aluvionar.

Tempos depois, em 1829, Andrada e Silva \& Francisco, realizaram uma excursão mineralógica pelo Estado, nos arredores da capital até Sorocaba. É descrito um caminhamento na região de Cotia e São Roque, onde ocorrem, palavras dos autores:

"[...]granitos grossos e syenitos granitiformes, que apresentam hum aspecto porphiridico por causa dos muitos cristaes de feldspato branco que o cobrem... Sobre o syenito, há grandes massas de schisto silicoso, penetrado de veios de quartzo... Próximo da freguesia de Cotia, passa ao gnaise [...].".

Os mesmos citam ainda a abundância e qualidade dos mármores da Ribeira de Iguape e Curitiba.

Derby, em 1878, sintetiza a geologia da porção SE dos estados do Paraná e São Paulo. O autor separa a geologia da região em três grandes grupos: a Região Montanhosa, ou Série Metamórphica - a qual já se utiliza o nome de Districto Assunguy - a região dos Campos Geraes - Região da Bacia do Paraná próximo a Ponta Grossa, inclusive com datação relativa devoniana por fósseis de Lamellibranchiata, Lingula, Spirifer, entre outros - e a terceira região, a de Trapps em função das escarpas condicionadas pelos derrames basálticos da Formação Serra Geral.

O reconhecimento geológico da região Sudeste do Brasil continuou se aprofundando com a criação da Comissão Geográphica e Geológica, em abril de 1886, cujo cargo de diretor pertenceu a Derby pelos primeiros 19 anos. Em Derby (1899), são discutidas as ocorrências de metais preciosos e básicos no Estado de São Paulo, e obviamente o Vale do Ribeira se mostra em lugar de destaque com as primeiras descobertas de ouro do período colonial, entre 1560 e 1580, além dos sinais de garimpo durante os séculos XVIII e XIX (figura 2, retirado de Knecht 1939). A região é posta em evidência ainda para Prata e Chumbo, na localidade de Iporanga.

Durante as primeiras décadas do século $X X$, os esforços da Comissão Geográphica e Geológica (1914), produziram um relatório pormenorizado com o 
mapeamento dos principais cursos d'água da bacia do Ribeira de Iguape, levantamento de coordenadas e levantamentos altimétricos, além de relatos sobre a geologia e estudos minuciosos sobre os sambaquis encontrados na região.

Passados treze anos, Oliveira (1927) elabora uma síntese da geologia do Estado do Paraná e evidencia um grande avanço de conhecimento. Já salienta, por exemplo, o reconhecimento do "Complexo Crystallino" - considerado então embasamento arqueano granito-gnáissico juntamente com rochas metamórficas de

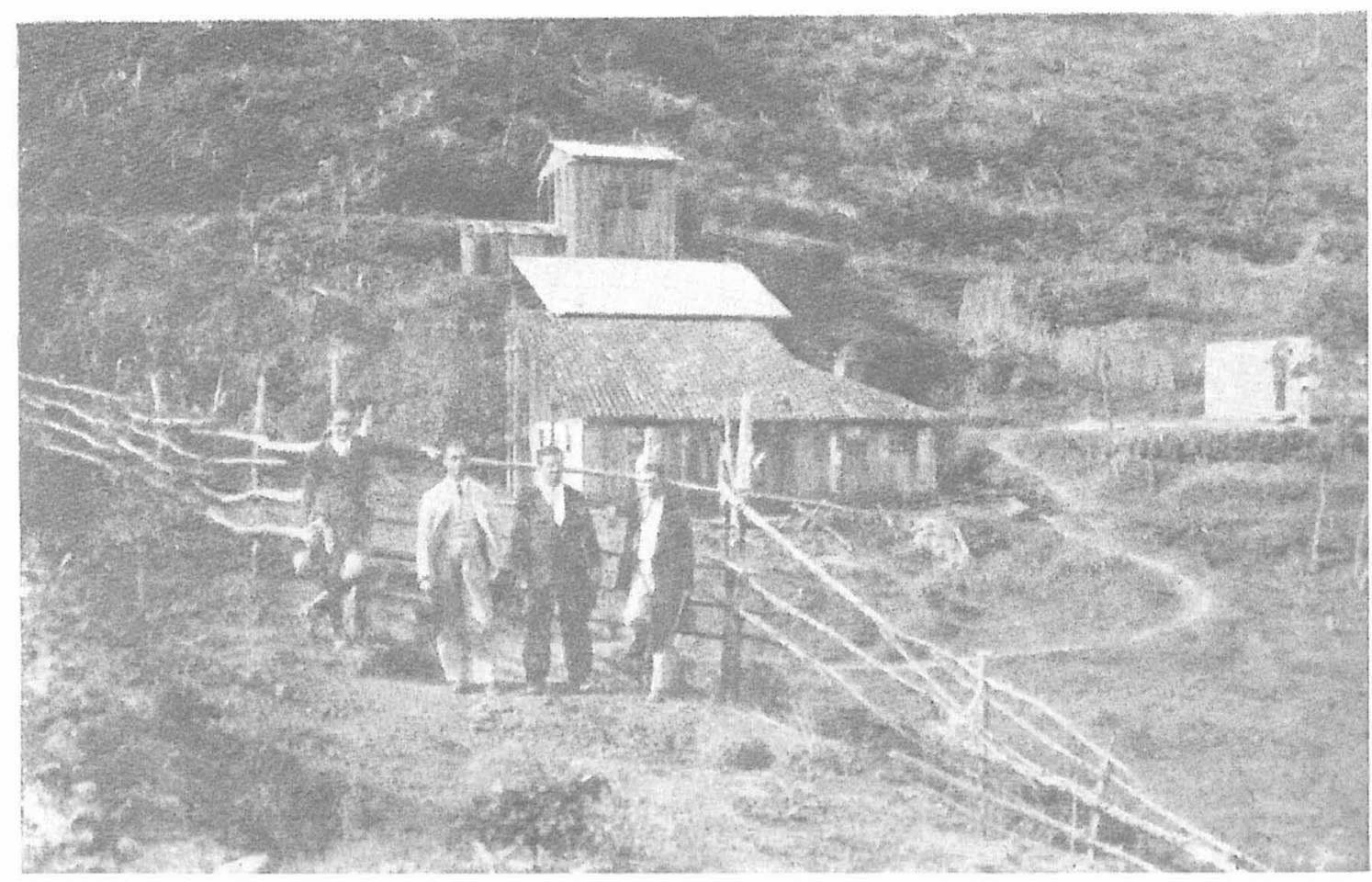

Figura 2. Antigas Instalações para extração de ouro no pé do Morro do Ouro no município de Apiaí (Fotografia tomada pelo engenheiro Othon Leonardos). Extraído de Knecht (1939).

alto grau "gneiss, schistos micaceos, schistos amphiboliferos talcosos..." - em detrimento da "Série do Assunguy" - "schistos argillosos, pouco metamorphisados, freqüentemente muito alterados pela acção atmospherica, calcareos e algum quartzito". O autor também chama atenção para a natureza diferente dos granitos do embasamento quando comparados aos intrusivos posteriores. Este atenta ainda, para as intrusões de diabásio que são comuns na região, além de trazer um apanhado geral das ocorrências minerais até então conhecidas no Paraná e região do Ribeira. 
Posteriormente, Moraes Rego (1941) generaliza todas as rochas metamórficas de baixo grau de São Paulo como Série de São Roque, individualizando zonas de ocorrência - área do Tietê, área de Juquiá, área da Serra de Itaqui, Área da Serra de S. Francisco, área do Vale da Ribeira de Iguape e área do Vale do Rio Grande. Ainda no final dos anos 1940, Barbosa (1948) realiza um perfil entre as cidades de Apiaí e Iporanga e critica a utilização do nome São Roque para designar as rochas metamórficas paulistas, sugerindo a utilização de Série Açungui para nomear as rochas da área.

As propostas de individualização de unidades metamórficas da então Série Açungui começam a surgir nos trabalhos da década de 1950. Bigarella e Salamuni (1958) sintetizam os resultados de seus trabalhos prévios (Bigarella 1948, Bigarella e Salamuni 1956) mostrando o mapa geológico da região de Rio Branco do Sul, a Norte de Curitiba. Separam três formações para o Grupo Açungui: a mais antiga é a Setuva, descrita no núcleo de uma dobra anticlinal, composta de sericita-quartzitos, quarzitos e filitos em discordância angular com a unidade sotoposta, Capirú. Esta formação caracteriza-se pela intercalação de quartzitos e dolomitos com fosseis de Collenia sp.(Figura 3).
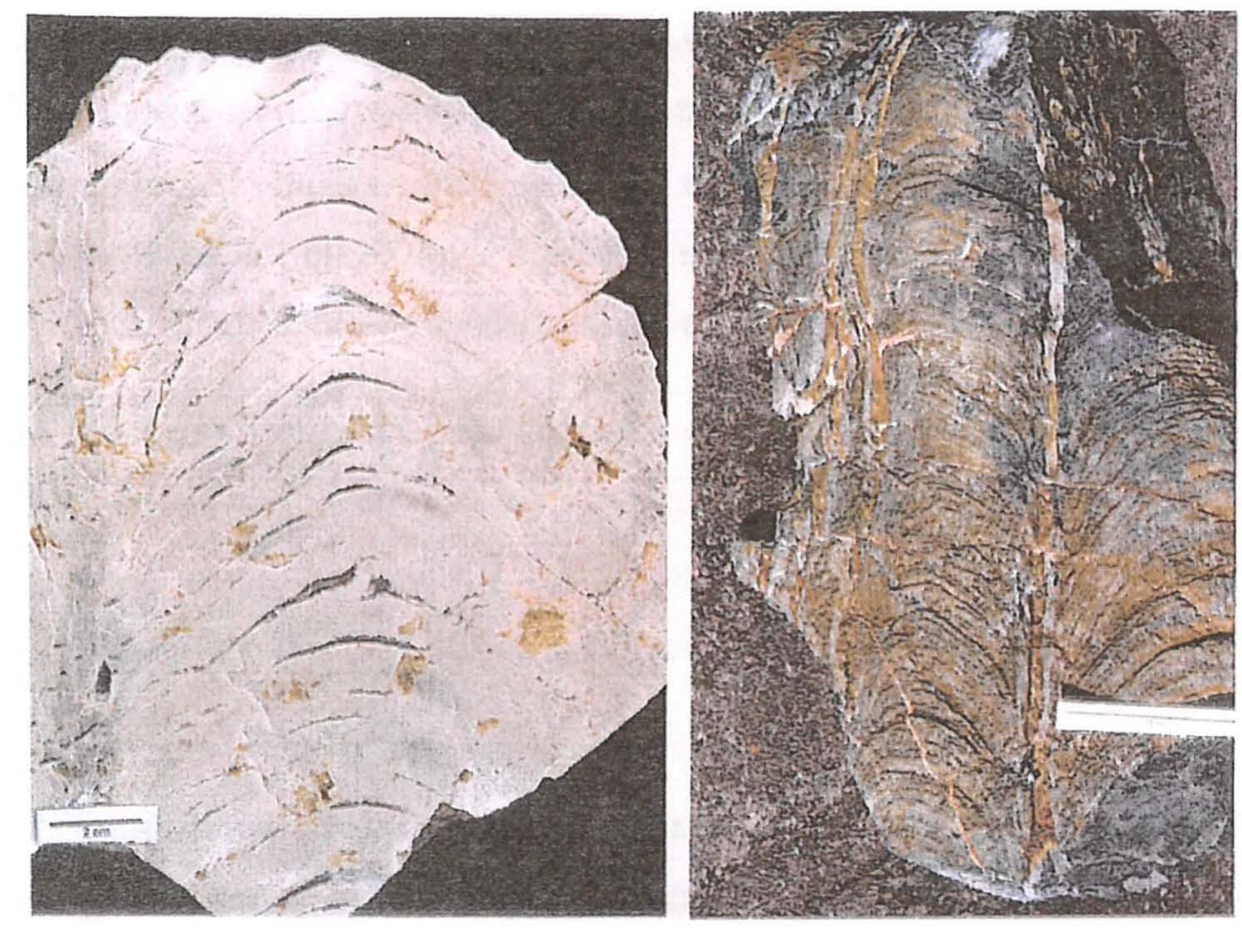

Figura 3. Seções polidas de rochas da Formação Itaiacoca, com estromatólitos gerados por Collenia itapevensis. (Sallun Filho, 1999). 
Concomitantemente, Almeida (1956) descreve a mesma formação na região do limite dos estados de SP e PR, nomeando-a de Itaiacoca. Por fim, sobrepõe-se a Formação Votuverava, cuja principal diferença entre a Capirú é a ausência de calcários dolomíticos e o predomínio de quartzitos em relação aos filitos com padrão de ritmicidade, além da ocorrência de corpos de itabiritos.

O grau metamórfico baixo característico da Série Açungui favoreceu o estudo das estruturas sedimentares contidas em suas rochas. $O$ trabalho de Petri \& Suguio (1969), foi pioneiro no estudo de estruturas sedimentares preservadas e conclui que o ambiente de sedimentação mais apropriado para as rochas da Formação Itaiacoca seria o de plataforma continental rasa com a região costeira situada a NW. O trabalho sugere ainda um ambiente de águas de grande salinidade, com $\circ \mathrm{Ph}$ elevado devido à atividade fotossintetizante, que retira $\circ \mathrm{CO}_{2}$ da água, tornando-a mais alcalina e favorecendo a precipitação de dolomitos.

A década de 1970 se destaca pelos mapeamentos em escala 1:250.000 realizados pela parceria DNPM/CPRM (Algarte 1974). O Grupo Açungui, no entanto não apresentava divisões estratigráficas. Esforços de reconhecimento regional e prospecção também foram realizados pelo I.G.G. - Instituto Geográfico e Geológico - no mesmo ano. Neste trabalho (I.G.G. 1974), são realizados caminhamentos na região de Cajati, Registro, além de um perfil de direção aproximadamente N-S desde a cidade de São Miguel Arcanjo até Sete Barras e confecção de esboços geológicos regionais. Ainda perdura, no entanto, a utilização de Grupo São Roque para as rochas metassedimentares de baixo grau metamórfico.

A separação do Grupo São Roque nas localidades norte e noroeste da cidade de São Paulo em relação ao Grupo Açungui foi sugerida por Hasui (1975). Ele propõe que as rochas a norte da falha de Taxaquara deveriam ser designadas Grupo São Roque e que apresentavam padrões estruturais diferentes das rochas do Açungui.

Estudos pormenorizados com levantamentos de perfis de detalhe, trabalhos petrográficos e a aplicação dos conceitos da tectônica de placas levaram a uma melhor divisão das unidades do Grupo Açungui durante a década de 1980. Ressaltam-se os trabalhos de Campos Neto (1983), Takahashi et al. $(1983,1984)$ e Chiodi Filho (1984). No primeiro, o autor estuda rochas da região de Iporanga e 
Apiaí e individualiza sete sequências de rochas, sendo: Seqüência Ribeirão das pedras, Betari, Iporanga, Furnas-lajeado, Gorotuba, Serra da Boa Vista e Rio Pardo. No segundo, são realizados os mapas 1:50.000 das folhas Capão Bonito e Guapiara, distinguindo os grupos Setuva e Açungui, além de considerar o Açungui correlacionável à Formação Votuverava. Por fim, os trabalhos de Chiodi Filho (1984), trazem uma sintese da geologia das regiões sul-paulista e leste paranaense, onde reconhece o Açungui subdividido nas Formações Votuverava, Capiru e Iporanga. O Grupo Setuva é considerado posterior e teria as Formações Itaiacoca, Água Clara e Peraú, bem como a Seqüência Turvo-Cajati. O embasamento seria representado pelos gnaisses e migmatitos do bloco costeiro, com o nome de PréSetuva.

Durante os anos de 1990, acontece a consolidação dos conhecimentos geológicos da região, numa fase de integração de dados e correlação através de idades geocronológicas mais robustas. Destacam-se os trabalhos de Campanha (1991), Basei et al. (1992) e Campanha e Sadowski (1999).

A tentativa de empilhamento estratigráfico das unidades do Grupo Açungui se mostrou bastante difícil e de maneira geral, confusa. A compreensão da geologia da Faixa Apiaí-Ribeira foi bastante melhorada com a partimentação tectônica dos terrenos adjacentes, conforme proposto por Basei et al. (1992) e Siga Jr., (1995). São quatro terrenos principais conforme a figura 4: Terreno Apiaí, Terreno Curitiba, Terreno Luis Alves e Terreno Costeiro ou Paranaguá. 


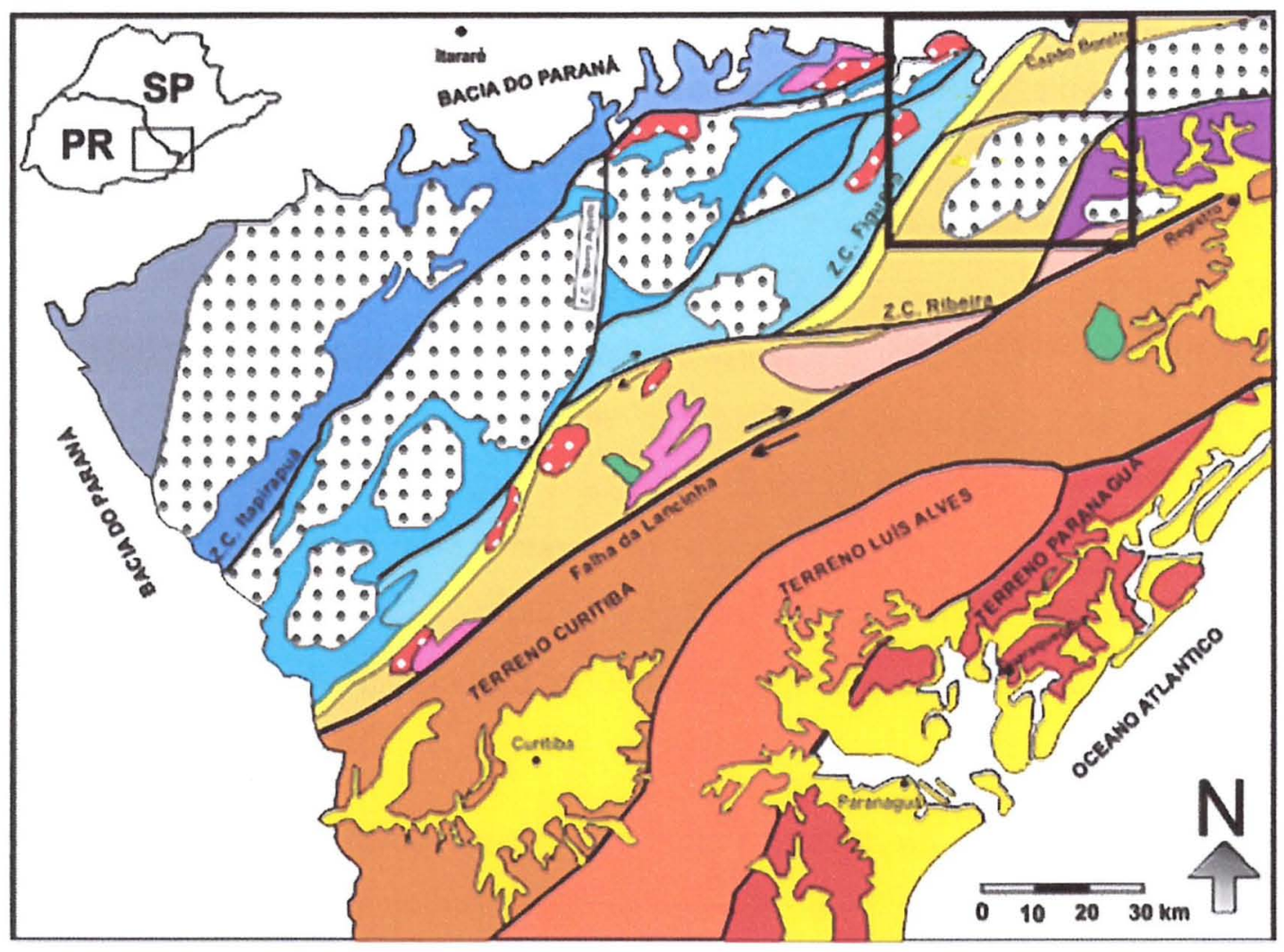

\section{Legenda}

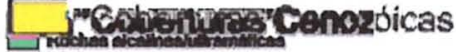

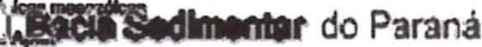 \\ Rochas alcalinasiultramáficas básicas mesozóicas}

\section{Terreno Apiai}

Grupo Castro (EdiacaranoCambriano)

Granitóides pós-colisionais, tipo A Formaçăo Iporanda (Ediacarano)

[- Suites Graniticas calcio-alcalinas (Ediacarano)

Grupo Itaiacoca (Neoproterozóico)

Grupo Lajeado (Meso a Neoproterozóico)

Serra das Andorinhas (Meso a

Neoproterozóico)

Grupo Votuverava (Mesoproterozóico)

Fomaçăo Água Clara (Mesoproterozóico)

\section{Embasamento Graissico}

(Palooprotsroź́ico)

Núcleos Tigre, Betara e Apiai-Mirim)

Complexo Embu

\section{Terreno Curitiba}

Embasamento gnáissico (Complexo Atuba), Supracrustais neo a mesoproterozóicas (Fm. Capiru, Setuva e Complexo Turvo-Cajati. Provincia Graciosa.

\section{Terreno Luis Alves}

Embasamento granulitico (Complexo Serra Negra), Bacia ediacarana Guaratubinha, suite ediacarana Rio Pién-Mandirituba. Provincia Gracios a - i i po A.

Figura 4. Mapa dos terrenos tectono-metamórficos da porção leste dos estados de São Paulo e Paraná, modificado de Faleiros (2008). Folha Capão Bonito em destaque, a NE. 


\subsection{Geologia Regional -Compartimentação Tectônica da Faixa Apiaí-Ribeira}

Conforme citado, são quatro os terrenos tectônicos propostos, os quais serão detalhados a seguir.

\subsubsection{TERRENO APIAI}

O chamado Terreno Apiaí (Heilbron et al. 2004) pertence à porção meridional do Cinturão Ribeira e compreende as rochas aflorantes a Norte da Falha da Lancinha. As rochas supracrustais individualizam-se no chamado Supergrupo Açungui (Campanha 1991). Dados cronológicos publicados principalmente a partir dos anos 2000 contribuíram em muito para a reinterpretação geológica da área. Atualmente, o Terreno Apiaí pode ser entendido como uma associação de terrenos tectono-metamórficos com idades entre o mesoproterozóico e o neoproterozóico, amalgamados provavelmente durante o final do neoproterozóico em um processo colisional oblíquo que resultou na formação de um sistema transcorrente predominantemente destral (Campanha \& Faleiros 2005).

No Terreno Apiaí, ocorrem porções de rochas do embasamento sendo predominantes os ortognaisses - ora miloníticos, ora migmatíticos - apresentando padrão deformacional-estrutural complexo resultado da interferência entre ciclos tectônicos anteriores.

Entre estas litologias ocorrem diversas intrusões graníticas tardi a póscinemáticas, variando de grandes batólitos a pequenos plútons localizados.

A área da folha Capão Bonito compreende justamente este Terreno Geotectônico, que será detalhado mais adiante - seção 5.2.3. 


\subsubsection{TERRENO CURITIBA}

O Terreno Curitiba é limitado a norte pela Falha da Lancinha e a Sul pela Zona de Cisalhamento Faxinal. É composto por quatro unidades geotectônicas principais: o Complexo Atuba, o Complexo Turvo-Cajati, a Suíte Rio Piên e as Seqüências Capiru-Setuva.

O Complexo Atuba caracteriza-se pela ocorrência de rochas gnáissicomigmatíticas, gnáissico-granulíticas, granito-gnáissicas, granitóides deformados, anfibolitos e xistos magnesianos (Siga Jr., 1995). Predominam, no entanto, os gnaisses bandados de leucossoma tonalito-diorítico e melanossoma a biotita e hornblenda.

O Complexo Turvo Cajati é formado por rochas metavulcanossedimentares em fácies xisto verde a anfibolito superior, ocorrentes a Sul da Falha de Lancinha. Foi correlacionado por Campanha (1991), com a Seqüência Serra das Andorinhas, que apresenta associações litológicas semelhantes, mas com grau metamórfico mais baixo. Neste mesmo trabalho, o autor obteve uma idade $\mathrm{Rb} / \mathrm{Sr}$ isocrônica de $728 \pm 26$ Ma para xistos da localidade de Barra do Turvo, que foi interpretada como idade do metamorfismo.

A Suite Granítica Rio Piên (Machiavelli, 1991 e Machiavelli et al. 1993) foi interpretada pelos autores como pertencente a um arco magmático do Proterozóico Superior. Sua composição é dada por granitóides heterogeneamente deformados. Têm granulação média a grossa, leucocrático, com cores cinza a róseo, podendo ocorrer megacristais isolados de feldspatos brancos ou róseos. Geoquimicamente, podem ser classificados como pertencentes às séries cálcio-alcalina granodiorítica, de médio K e cálcio-alcalina monzonítica de alto K (Siga Jr., 1995).

A Seqüência Capiru-Setuva é composta pelas formações homônimas. São coberturas metassedimentares em fácies xisto verde a anfibolito. Bigarella e Salamuni (1956) definiram estas formações na porção leste do estado do Paraná, e indicaram a Formação Setuva como base da Série Açungui. Posteriormente, Campanha (1991), estende a ocorrência da Formação Setuva para a porção 
Paulista, incluindo as Seqüências Serra das Andorinhas e Turvo-Cajati. A posição estratigráfica desta seqüência continua sendo alvo de discussões e a razão para tal é discutida no trabalho de Fiori (1992), que evidencia a preservação da estratigrafia interna da unidade, mas atenta para a dificuldade de sobreposição estratigráfica em relação a unidades maiores, oriunda da aloctonia destas rochas em relação ao embasamento.

\subsubsection{TERRENO LUIS ALVES}

Esta unidade litotectônica é caracterizada principalmente pelo seu alto grau metamórfico em fácies granulito. Seus litotipos predominantes são os gnaisses granulíticos, bandados a maciços, de composição tonalitogranodiorítica, com freqüentes variações a granulitos básicos (Siga Jr. 1995).

A região de exposição forma uma faixa alongada na direção NE-SW, em média com $30 \mathrm{Km}$ de largura e que parte desde a região de Luis Alves e Barra Velha até o limite PR-SP, na região de Morretes e Serra Negra (Figura 4).

Trabalhos de Hartmann et al. (2000) apresentam datações arqueanas em zircão pelo método U-Pb SHRIMP (2716 $\pm 17 \mathrm{Ma})$, para os protolitos do Terreno Luis Alves. Foram identificados ainda, quatro eventos metamórficos, sendo que os

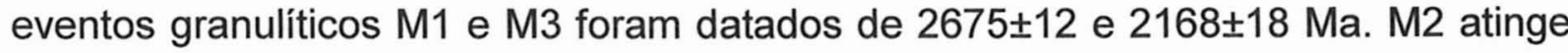
fácies anfibolito e ocorre sincronicamente a M3, e M4 é o metamorfismo em zonas de cisalhamento, evidenciado pela cristalização de clorita e epidoto.

\subsubsection{TERRENO PARANAGUÁ}

O Terreno Paranaguá se situa na borda atlântica dos estados do de SC, PR e sul de SP e limita-se a Oeste pelo Terreno Luis Alves. É formado por um complexo ígneo com grande variedade de granitos encaixados em gnaisses, mica xistos, quartzitos e anfibolitos. Predominam granitóides leucocráticos, de granulação média 
a grossa, geralmente foliados, de cor cinza clara e rico em megacristais de feldspato potássico zonado de tamanho variando entre 2 a $5 \mathrm{~cm}$ (Siga Jr. 1995).

Ainda segundo Siga Jr. (1995), quando estas rochas são de granulação grossa, predominam as feições de orientação mais incipientes, como foliações apenas a nível da biotita e leve imbricamento dos megacristais, o que seria relacionado a fluxo magmático. Já nas porções mais a oeste, estas rochas se apresentam muito mais deformadas, apresentando até mesmo aspecto migmatítico.

Datações pelo método $\mathrm{Rb}-\mathrm{Sr}$ em rochas granitóides da região de Paranaguá obtiveram idades de $537 \pm 35 \mathrm{Ma}$. Amostras da região de Guaratuba apresentaram idade de 562 \pm 33 Ma, pelo mesmo método (Basei et al. 1990, Siga Jr. 1995).

\section{$\underline{6.3 \text { Geologia local - Unidades Aflorantes }}$}

$\mathrm{Na}$ folha Capão Bonito, afloram quatro grandes grupos de rochas (figura 4). Em sua porção sul, ocorrem metassedimentos do grupo Açungui. A faixa central da folha é composta essencialmente pelo batólito de Agudos Grandes. Para norte, continuam os metassedimentos até o limite da folha, onde aflora o capeamento sedimentar Permo-Carbonífero da Formação Itararé, bacia do Paraná. Na porção extremo sudeste da folha, ocorrem rochas do embasamento pertencentes ao Complexo Embu. Toda a área é entrecortada por diques de diabásio de direção NWSW. Ainda na parte SE, há sedimentos quaternários da bacia do rio Ribeira de Iguape, além de algumas ocorrências de depósitos supostamente terciários do Gráben de Sete Barras.

A seguir, serão descritas sucintamente as unidades anteriormente citadas, respeitando a ordem estratigráfica aceita, do mais velho para o mais novo.

\subsubsection{EMBASAMENTO - COMPLEXO EMBU}


As rochas do embasamento presentes na folha Capão Bonito limitam-se à porção sudeste da área. São gnaisses ora migmatíticos, ora miloníticos, predominando os últimos. Apresentam-se finamente bandados, com bandas de 2$5 \mathrm{~mm}$ separando o melanossoma rico em biotita e um leucossoma quartzofeldspático. Ocorrem também, corpos de anfibolito de expressivos, intercalados a estes gnaisses.

Segundo Hasui et al. (1981), as rochas do Supergrupo Açungui são separadas do Complexo Embu exatamente na região da área de estudo, no contato com o Batólito de Agudos Grandes. Descrições mais aprofundadas das litologias do Complexo podem ser encontradas em Fernandes (1991), que estudou a unidade na porção leste paulista, principalmente na região de São José dos Campos, Jambeiro e Paraibuna. A autora separa três unidades informalmente: Rio Una, Redenção da Serra e Rio Paraibuna.

A unidade Rio Una é formada por xistos em pacotes métricos a centimétricos, intercalados com quartzitos impuros subordinados. São formados por quartzo, biotita e muscovita, sendo que em algumas regiões ocorre sillimanita em abundância. A granada aparece raramente, e em apenas uma localidade próxima a Paraibuna foi relatada a presença de estaurolita. Os contatos destas unidades com as adjacentes são tectônicos e evidenciados pelas rochas miloníticas das zonas de cisalhamento de Cubatão, Guararema, Alto da Fartura e de Santa Rita.

A unidade Redenção da Serra aflora na região de Taubaté e é dividida em duas subunidades, sendo a primeira composta por granada-sillimanita-biotita gnaisses e a segunda, por biotita gnaisses tonalíticos a granodioríticos associados a rochas calcissilicáticas e anfibolitos.

Por fim, a unidade Rio Paraibuna, aflorante em sua maior parte a sul da Zona de Cisalhamento de Cubatão, é composta por litotipos muito similares aos da unidade Redenção da Serra, mas se diferencia pela presença de lentes de quartzito em maior quantidade, formando camadas métricas placosas entre as rochas calcissilicáticas e gnáissicas. 


\subsubsection{SUPERGRUPO AÇUNGUI}

De maneira geral, o Supergrupo Açungui compreende todas as rochas supracrustais aflorantes no Terreno Apiaí, a norte da Falha da Lancinha, além da Seqüência Capiru-Setuva, também ocorrente a sul desta estrutura (Terreno Curitiba). Estas rochas estão dispostas em sua grande parte segundo a direção NESW, localmente N-S, e compõe a faixa oriental do Cinturão Ribeira. Limitam-se a Norte com as rochas do Complexo Embu, bem como com os metamorfitos de baixo grau do Grupo São Roque, e a sul e a oeste, encontram-se soterradas pelos sedimentos da Bacia do Paraná. Seu limite leste é marcado pela Falha da Lancinha, a partir da qual, para sul, afloram as rochas do Terreno Curitiba.

A compartimentação estratigráfica adotada para o Supergrupo Açungui foi a de Campanha (1991). Segundo o autor, o Supergrupo Açungui subdivide-se em cinco unidades, uma delas dividida em duas subunidades, conforme o esquema abaixo (Campanha 1991), e detalhadas a seguir:

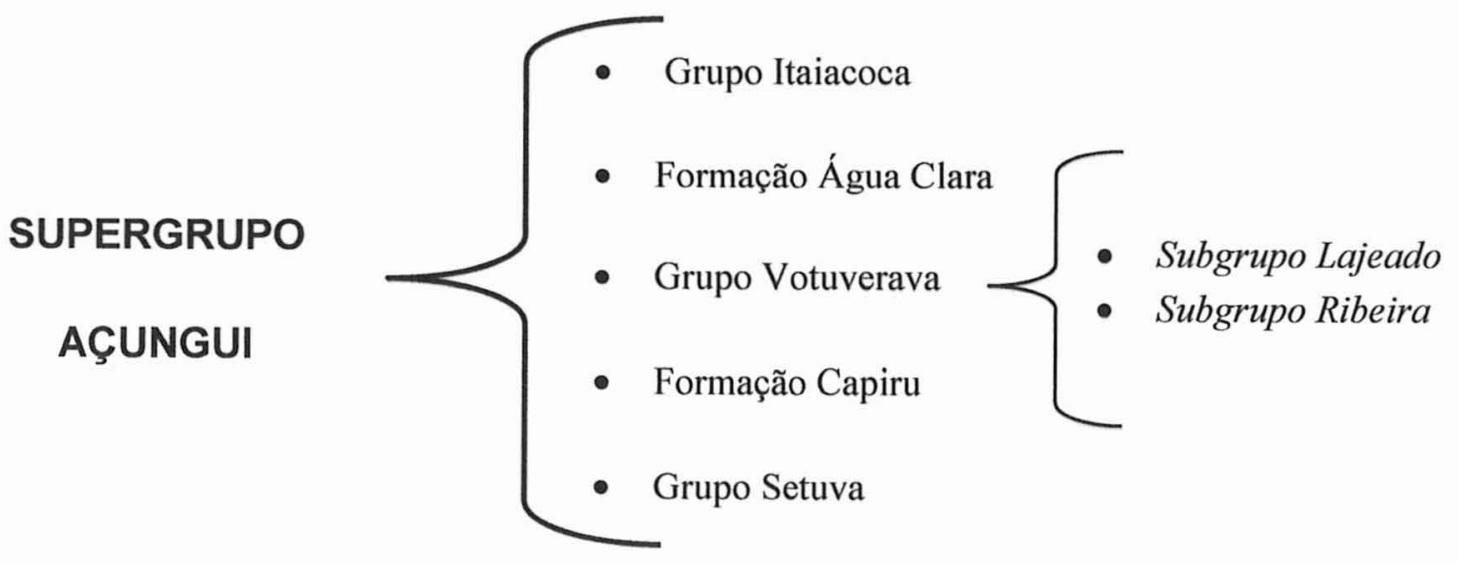

\subsection{2a- Grupo Setuva}

A Formação Setuva foi originalmente descrita por Bigarella e Salamuni (1956). Segundo estes autores, seria considerada a unidade basal da então Série Açungui, aflorante na estrutura anticlinal homônima. É formada por sericitaquartzitos, xistos aluminosos,paragnaisses e quartzitos e ocorre no núcleo de 
diversas estruturas antiformes a norte da Falha da Lancinha, como as da Anta Gorda, da Betara e do Cerne (Campanha, 1991).

Em São Paulo, é considerado como a Seqüência Turvo-Lajeado e a Seqüência Serra das Andorinhas, situada entre os lineamentos Ribeira e Lancinha (Campanha et al., 1985; Campanha, 1991). Segundo o autor, a Seqüencia Serra das andorinhas apresenta grande similaridade em termos de protolito com rochas do Terreno Curitiba, sendo diferenciadas pelo grau metamórfico mais baixo.

As relações estratigráficas entre a Formação Setuva e suas sotopostas, bem como sua extensão ainda são fontes de discussão entre diversos autores. Segundo Campanha (1991), o Complexo Embu, ocorrente na porção setentrional da Faixa Ribeira ainda poderia ser considerado como provável continuidade da Formação Setuva a norte do lineamento Ribeira/Cubatão.

Trabalhos mais recentes, no entanto, têm rebaixado o Grupo Setuva à categoria de Formação, e descrito as formações Capiru e Setuva como correlatas, sendo a última uma tectonofácies da primeira (Fiori 1994, Faleiros 2008).

\subsection{2b - Formação Capiru}

Correlata à Formação Itaiacoca, consiste de uma seqüência plataformal de águas rasas, com linha de costa para NW (Petri \& Suguio, 1969). Litologicamente compreende mármores predominantemente dolomíticos, por vezes silicosos, além de pacotes pelíticos e psamíticos. Destacam-se a presença de fósseis do tipo Collenia sp. (Figura 3), indicadores de águas rasas, límpidas e com grande atividade biológica fotossintetizante (Sallun Filho 1999).

Embora o baixo grau metamórfico e a baixa deformação da maioria das unidades da Formação Capiru seja evidente, foram relatadas porções fortemente deformadas por sistemas de empurrão na base desta unidade (Fiori 1992, Campanha 1991, Faleiros 2008), representando uma aloctonia importante desta unidade em relação a seu embasamento. 
Estudos recentes têm considerado as Formações Capiru e Setuva como uma Seqüência única e correlata, sendo que sua maior expressão ocorre no Terreno Curitiba (Fiori 1994, Campanha \& Sadowsky 1999, Faleiros 2008).

\subsection{2c-Grupo Votuverava}

O Grupo Votuverava engloba a Formação Votuverava originalmente descrita em Bigarella e Salamuni $(1956,1958)$, bem como a Formação Perau (Campanha 1991) - sua extensão a norte da Zona de Cisalhamento Ribeira - e ao subgrupo Ribeira (Campanha 1991). Os litotipos predominantes são metapelitos rítmicos, finamente laminados alternando filitos, ardósias e quartzo-sericita xistos finos, considerados como uma seqüência distal turbidítica (Petri e Suguio 1969, Campanha e Sadowsky 1999).

Ocorre ainda grande quantidade de corpos de rochas metabásicas, além de lentes de quartzitos e raras metavulcânicas. Camadas delgadas e descontínuas de formação ferrifera são observadas subordinadamente.

Perrotta (1997) apresenta uma subdivisão do Grupo Votuverava na porção a norte da Zona de Cisalhamento Ribeira (ZCR), em quatro unidades: Nhunguara ocorrente logo a norte do contato com a ZCR e caracterizada por sericita-quartzitos com clorita, finamente laminados com intercalações milimétricas a centimétricas de filito carbonoso - Piririca - sobreposta à unidade Nhunguara, composta por filitos carbonosos microporfiroclásticos com espessas intercalações de metabásicas Ribeirão das Pedras (Campos Neto 1983) - pacotes rítmicos de filitos brancos sericíticos, metacherts, metassiltitos e metarenitos finos ferruginosos - e por fim, Unidade Rubuquara - filitos ardosianos violáceos homogêneos ou bandados, com intercalações de bancos de metarenitos conglomeráticos.

Datações em rochas metabásicas ocorrentes entre as rochas da Formação Votuverava e Peraú apontam idades Mesoproterozóicas para a deposição do grupo. A exemplo, zircões em anfibolitos datados por Basei et al. (2003) pelo método U-Pb convencional, forneceram a idade de $1479 \pm 12$ e $1484 \pm 16$ para cada unidade, respectivamente. Daitx (1996, apud Campanha e Sadowsky 1999) datou xistos 
pelíticos da Formação Peraú pelo método $\mathrm{Rb} / \mathrm{Sr}$ e obteve uma idade de $730 \pm 16 \mathrm{Ma}$, interpretada como idade de metamorfismo.

\subsection{2d - Formação Água Clara}

Consiste de uma seqüencia deposicional carbonática impura, composta por mármores negros, predominantemente maciços, podendo haver porções com estratificações preservadas (calcarenitos). São intercalados por rochas calcissilicáticas e metapelitos - Fácies São Domingos. Uma seqüência vulcânica também faz parte da formação, composta por anfibólio-xistos, granada-clorita-biotita xistos, metacherts, metatufos básicos e cornubianitos - Fácies São Silvestre (Campanha 1991).

Sobre seu metamorfismo, observa-se um padrão de aumento de SE para NW, variando de baixo - onde podem ser encontradas estruturas sedimentares reliquiares - a médio superior - metamorfismo térmico, zonas de cisalhamento (Almeida et al. 1986).

As zonas de cisalhamento são as estruturas condicionantes dos contatos desta unidade com as Formações Itaiacoca e o Grupo Lajeado. Zonas de cisalhamento dúcteis de baixo ângulo caracterizam os contatos com os Complexos Três Córregos e Apiaí-Mirim (Campanha 1991).

\subsection{2e - Grupo Itaiacoca}

Inicialmente descrita por Almeida (1956), a Formação Itaiacoca é considerada correlata à Formação Capiru de Bigarella e Salamuni (1956). É formada por uma seqüência carbonática predominantemente dolomítica, intercalada por pacotes pelíticos e psamíticos. Por vezes seus mármores podem apresentar estruturas bioinduzidas (estromatólitos de Collenia $s p$.) e estruturas oolíticas. Lentes delgadas de arenitos finos são interpretados como níveis de chert, o que sugeriria segundo 
Campanha (1991), um ambiente deposicional calmo de lagunas isoladas por recifes/atóis, onde o aporte de material clástico é menor.

Estudos paleoambientais clássicos (Petri e Suguio 1969) indicam um ambiente deposicional para esta unidade de águas rasas e litorâneas, com fácies distais mais distais para SE e linha de costa para NW.

Porções com contribuições vulcânicas básicas a intermediárias são descritas na região de Abapã $(P R)$ - basaltos, basaltos andesíticos, andesitos, e até mesmo riolitos - e Ribeirão Branco (SP) - intercalações de metavulcânicas de caráter toleiítico diversas em pacotes metapsamíticos arcoseanos e metaconglomeráticos podem caracterizar um vulcanismo bimodal (Campanha 1991).

\subsubsection{INTRUSÕES GRANÍTICAS NEOPROTEROZÓICAS}

Em toda a Faixa Apiaí-Ribeira existem diversos plútons de granitos e granitóides intrudindo as sequencias supracrustais. Segundo Janasi (2003), Trata-se de um magmatismo cálcio-alcalino potássico de caráter metaluminoso, cuja granitogênese é datada do final do neoproterozóico ( $610 \mathrm{Ma})$, em um regime sinorogênico - batólitos Agudos Grandes, Três Córregos e Cunhaporanga.

Cerca de um terço de todas as rochas aflorantes da área de estudo são granitos. Correspondem principalmente à faixa central da folha, sendo o litotipo que sustenta a serra do Paranapiacaba. Esta feição em particular é composta pelos granitos do Batólito de Agudos Grandes, os quais são em geral leucocráticos, de granulação média a grossa e cor cinza. Seus máficos dominantes são a biotita e subordinadamente hornblenda e podem apresentar tanto porções mais maciças quanto outras bem foliadas, orientadas segundo a foliação regional (NE-SW) e/ou paralelamente ao seu contato.

A granitogênese pós-orogênica associada ao sistema compressivotranspressivo do Ribeira tem sua maior expressão a leste da cidade de São Paulo, no batólito de Itu - granitos rapakivi - com aproximadamente 565 Ma (Janasi, 2003). 


\subsubsection{SEDIMENTAÇÃO PALEOZÓICA - BACIA DO PARANÁ}

A unidade da Bacia do Paraná aflorante na região da folha Capão Bonito é a Formação Itararé, pertencente à Superseqüência Gondwana I (Milani et al. 2007) . Este grupo de rochas é caracterizado por sua deposição em ambiente glacial. A parte basal dessa sequencia é caracterizada pela alternância de três grandes pacotes com granodecrescência ascendente, variando de pacotes arenosos a porções argilosas podendo haver intercalações de diamictitos. Podem ocorrer ainda seixos esparsos em meio a rochas de sedimentação fina - os 'clastos caídos' - além de arenitos com deformações sin-sedimentares, principalmente dobras atectônicas e de ritmitos finamente laminados (fácies turbidítica).

\subsubsection{A SEDIMENTAÇÃO TERCIÁRIA - QUATERNÁRIA}

Ocorre, no extremo SE da folha, na região do Vale do Ribeira - proximidade da cidade de 7 Barras - uma depressão alongada por cerca de $20 \mathrm{Km}$ na direção NE-SW, por até $5 \mathrm{Km}$ de extensão. Feição conhecida como o Gráben de Sete Barras, como proposto por Riccomini (1989), Melo et al. (1989) e Melo (1990). Este baixio apresenta-se preenchido por sedimentos assumidos por estes autores como terciários, estando relacionados à fase tafrogênica do SE do Brasil.

Sondagens elétricas verticais conduzidas por Melo et al. (1989), estimaram uma profundidade de sedimentos de até $200 \mathrm{~m}$. Constatou-se ainda, um aumento da coluna de sedimentos de NE para o centro da bacia o que sugere um basculamento assimétrico dos blocos rebaixados tanto para SW como para SE.

Litologicamente é composta por camadas ortoconglomeráticas, areias e depósitos de corrida de detritos, decorrentes da forte erosão nas bordas da depressão. Na região mais central do gráben, predominam lamas que, segundo Melo $(1989,1990)$, teriam sido depositadas em um paleolago central. 
Estas rochas ocorrem capeadas em discordância erosiva com a Formação Pariquera-Açu, conforme denominada por Bigarella \& Mousinho (1965), posteriormente citada e estudada por diversos outros como Petri \& Suguio (1973) Hasui et al. (1978), Riccomini (1989) e Melo (1990). São predominantemente de textura fina, com intercalações de siltitos areno-argilosos e areias arcoseanas, associando-se às porções mais rudáceas camadas de cascalhos e conglomerados. Alguns destes conglomerados podem ser semelhantes a diamictitos, com clastos de até $30 \mathrm{~cm}$, arredondados e dispersos em matriz fina. Petri \& Suguio (1973), atribuem a esta formação a gênese em ambiente sedimentar fluvial transicional a marinho. As idades mais aceitas seriam do terciário, já que estes sedimentos parecem estar falhados por estruturas associadas ao Rift Continental do Sudeste (Riccomini, 1989).

Sotoposto a estas unidades, há o capeamento aluvionar atual, em processo de deposição em toda a planície de inundação do Ribeira de Iguape. São conglomerados finos a médios, areias conglomeráticas e lentes silto-argilosas, com uma ampla ocorrência em toda a região.

Apesar de serem formalmente divisas em tese, estas unidades apresentam litologias similares e podem se tornar dificilmente distinguíveis em campo. Segregam-se principalmente, pela diferença de altitude entre os terraços antigos em que ocorrem, o que leva a discussões estratigráficas mais aprofundadas em Melo (1990).

\subsection{Geomorfologia da Borda Continental Paulista}

Até o começo do século XIX, a região de São Paulo e Paraná carecia de estudos geológicos e geomorfológicos de destaque. A maioria das informações da época, que persistem até hoje, consistem de relatos de viajantes naturalistas e geógrafos que estiveram na região. Destacam-se os trabalhos de Andrada (1805) e Andrada e Silva \& Francisco (1829), bem como os de John Mawe (1812), citados em Ab'Saber (1957) - como os pioneiros nos estudos geológicos e geomorfológicos da borda oriental paulista. 
Ab'Saber destaca ainda os trabalhos do francês A. Pissis, realizados durante a década de 1840. O cientista tem como seu principal legado a delimitação das bacias de sedimentação terciária situadas no planalto cristalino e associadas ao Rift do Sudeste, separando-as das bacias sedimentares costeiras recentes.

Apesar destes estudos pioneiros, os trabalhos no âmbito da geomorfologia no Estado de São Paulo só se alavancam durante os anos de 1930. O primeiro esboço geomorfológico do Estado é atribuído a Moraes Rego (1932) e pode ser visto na figura 5. A década de 1950, por sua vez, protagonizou uma importante evolução no que tange a geomorfologia, graças a três grandes trabalhos: a publicação de Ab'Saber (1956), 'A terra Paulista' onde há um mapa do 'esquema

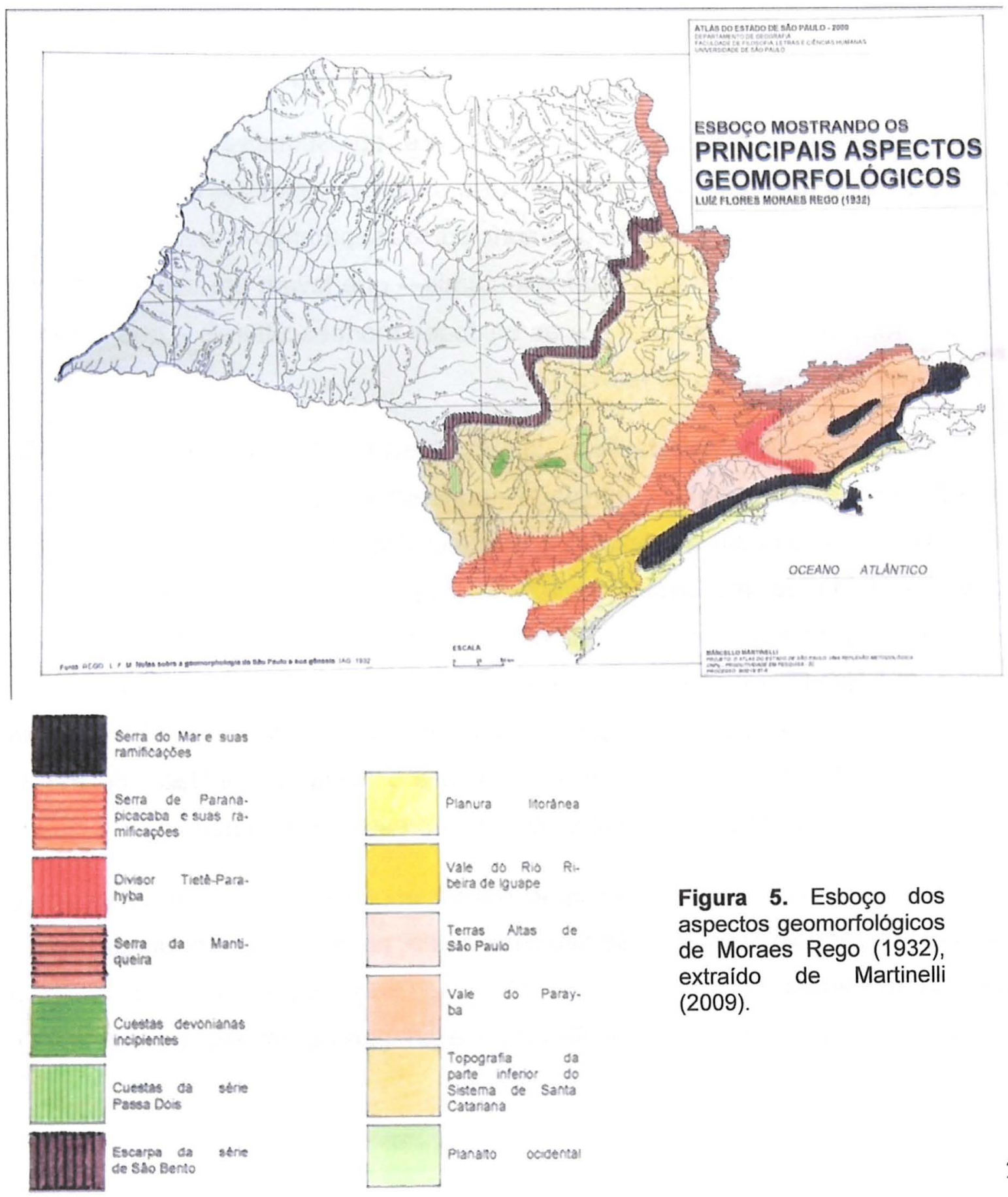


morfológico' do estado, e as publicações de Almeida (1953) - onde o autor inquire sobre a formação da Serra do Mar e especula uma idade cenozoica para a formação da feição - e Almeida (1958) - estudo da geomorfologia do Planalto Paulistano e definição da Superfície de Aplainamento do Japi.

Em 1981, o IPT - Instituto de Pesquisa Tecnológica - publica o mapa geomorfológico do estado de São Paulo ao milionésimo (Carneiro et al. 1981), já realizado utilizando imagens de satélite LANDSAT e levantamentos aeroportados de radar do projeto RADAMBRASIL. O avanço realizado por este mapa, no entanto, é maior no âmbito tecnológico do que na evolução do conhecimento geomorfológico em si, já que os principais contornos da geomorfologia do estado já haviam sido delimitados com bastante fidelidade já na década de 1970, por Almeida (1974).

Atualmente, a divisão geomorfológica mais representativa do estado de São Paulo é o mapa na escala 1:500.000 de Ross e Moroz (1993). Os autores procuram fazer a individualização de feições geomorfológicas separando o meio físico em dois tipos de unidades: as unidades morfoestruturais - que levam em conta a afinidade litoestrutural das rochas do local - e as unidades morfoesculturais - que levam em conta principalmente o tipo de relevo.

A borda continental paulista, segundo esta subdivisão, é formada pelo Cinturão Orogênico Atlântico (unidade morfoestrutural), subdividido em faixas paralelas de acordo com o relevo (e.g. Planalto Atlântico e Planalto de Ibiuna/São Roque - unidades morfoesculturais). Ao longo de sua extensão, apresenta depressões tectônicas, como o Graben de Sete Barras - aqui nomeado de Depressão baixo Ribeira - e bacias sedimentares cenozóicas como as de Taubaté e São Paulo, perfazendo em conjunto, outra unidade morfoestrutural dominante. Limita-se a leste com a sedimentação costeira e a oeste com a Bacia do Paraná, nas depressões da borda do planalto, como a depressão Paranapanema.

A área deste estudo, folha Capão Bonito, engloba uma grande variedade de unidades geomorfológicas, indo de seu limite norte, na depressão Paranapanema, já na Bacia do Paraná, para as regiões do Cinturão Orogênico Atlântico - planaltos de Guapiara, de Ibiúna/São Roque e Ribeira - e chegando, em seu extremo sul, na 
Depressão do Baixo Ribeira nas proximidades de Eldorado (figura 6). Esta grande variedade geomorfológica implica em uma diferença de cotas máxima e mínima para folha de cerca de $800 \mathrm{~m}$, já que as cotas na região da Serra do Paranapanema chegam a $850 \mathrm{~m}$ e, próximo a Eldorado, o terreno é abatido e pode ficar abaixo dos $50 \mathrm{~m}$ de altitude.

\subsection{Neotectônica da Borda Leste Paulista}

A neotectônica é a parte da geologia que estuda os movimentos recentes da crosta terrestre. Esta ciência floresceu na antiga União Soviética no final dos anos de 1940 e, conforme relembrado por Saadi (1993), sua definição mais atual é a adotada pela Associação Internacional dos Estudos do Quaternário (INQUA) em 1978: "quaisquer movimento ou deformação do nível geodésico de referência, seus mecanismos, sua origem geológica, independentemente de sua idade, suas implicações para vários propósitos práticos e suas futuras implicações".

Ainda segundo Saadi (1993), o estudo das litoestruturas nos permite não só ter ideia da movimentação recente - e quiçá atual - da crosta, mas também aplicar conceitos de atualismo para compreender movimentos mais antigos registrados nas rochas.

As formas de relevo mais comumente associadas a movimentos neotectônicos no Estado de São Paulo são a Serra do Mar, a Serra da Mantiqueira e as depressões e bacias de sedimentação cenozóicas. Todas elas são controladas por uma estrutura de centenas de quilômetros, compreendendo a borda leste dos estados do Paraná, São Paulo e Rio de Janeiro: o Rift Continental do Sudeste do Brasil (RCSB) (Riccomini 1989). Sua geração ocorreu durante o Oligoceno, através da reativação de zonas de cisalhamento pretéritas de direção preferencial NE-SW, gerando uma série de grábens paralelos a esta direção, e limitados por falhas NNESSW. Sua extensão total vai desde a cidade de Curitiba (PR) até Niterói (RJ), perfazendo mais de $900 \mathrm{~km}$ de extensão (Figura 7). 

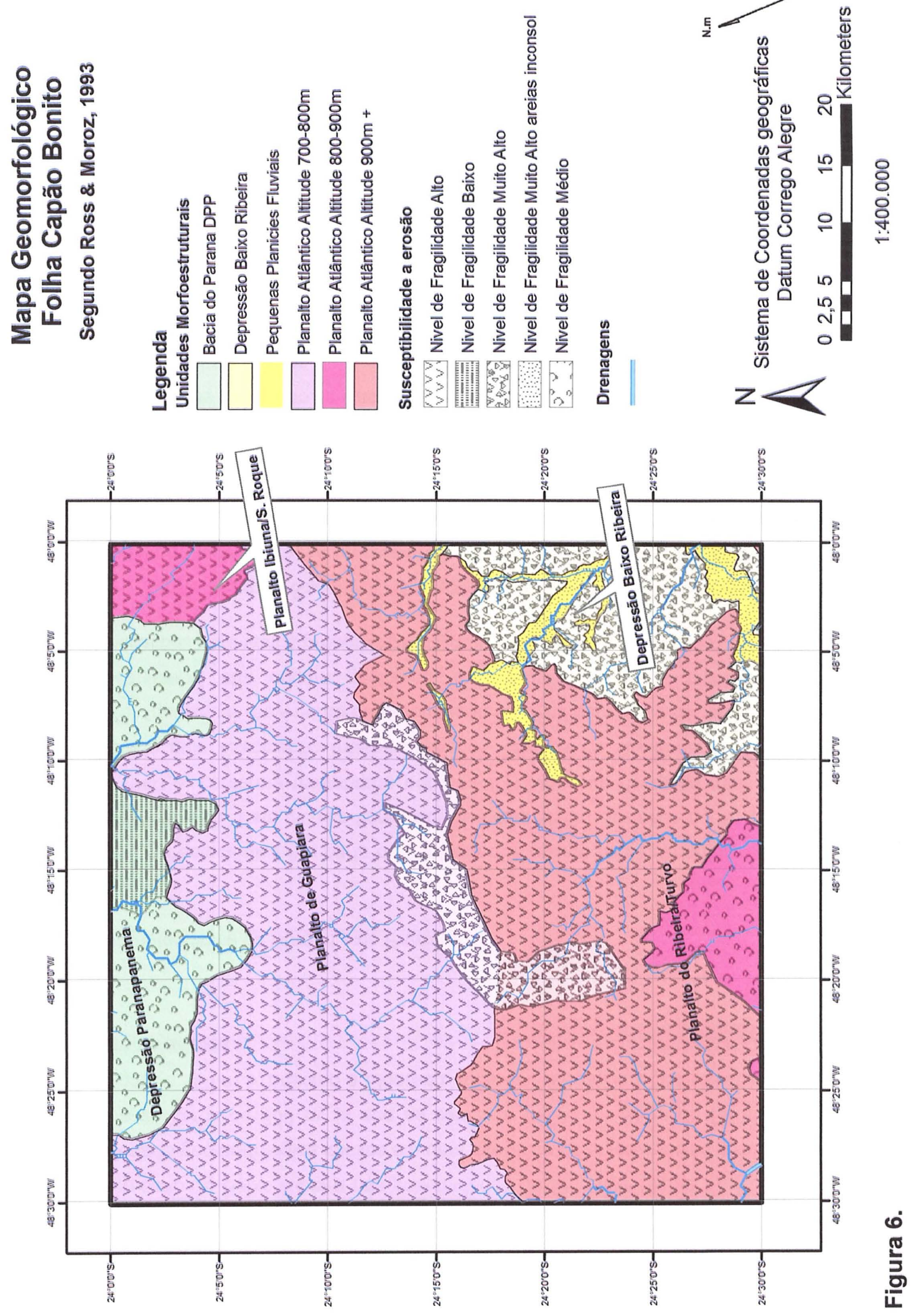


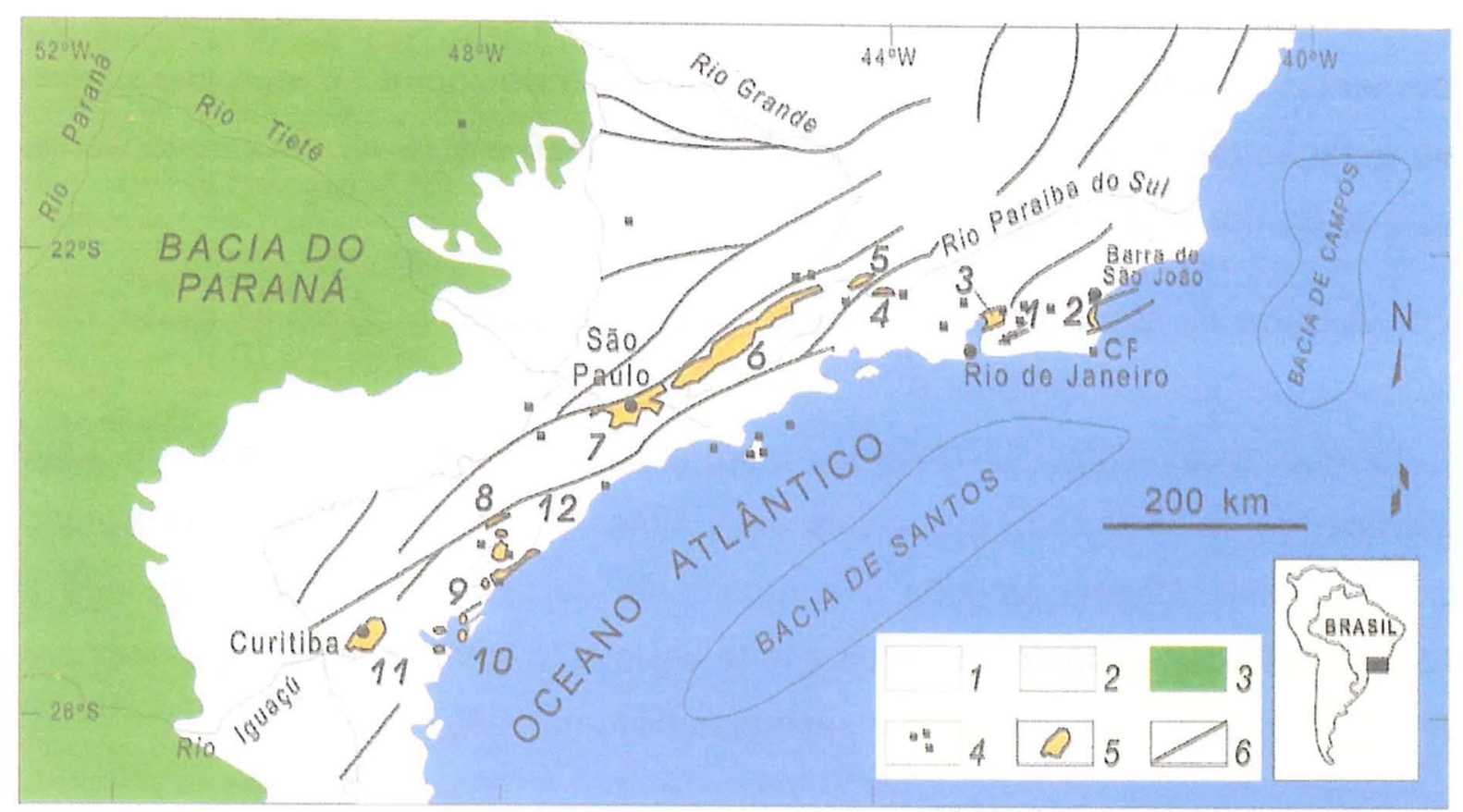

Figura 7. Configuração do Rift Continental do Sudeste do Brasil (Riccominiet al. 2004). 1. Embasamento Pré-Cambriano. 2. Rochas sedimentares Paleozóicas da Bacia sedimentar do Paraná. 3. Rochas vulcânicas toleiíticaseo-cretáceas da Formação Serra Geral. 4. Rochas relacionadas ao magmatismo alcalino mesozóico-cenozóico. 5. Bacias cenozóicas do rift (1- Bacia do Itaboraí, 2- Graben de Barra de S. João, 3- Bacia do Macacu, 4- Bacia de Volta Redonda, 5Bacia de Resende, 6- Bacia de Taubaté, 7- Bacia de São Paulo, 8- Graben de Sete Barras, 9Formação Pariquera-Açu, 10 Formação Alexandra e GrabenGuaraqueçaba, 11- Bacia de Curitiba.

A feição mais marcante do RCSB é a bacia de Taubaté, depressão alongada com mais de $200 \mathrm{~km}$ de extensão, por em média $30 \mathrm{~km}$ de largura. Limita-se a NW pelas terras altas da Serra da Mantiqueira e a SE pela borda da Serra do Mar. Bacias com sedimentação análoga a esta e outras depressões ocorrem ao longo de toda a extensão do rift tais como a de Curitiba, o Graben de Sete Barras (Melo et al. 1989, Melo, 1990) na região de estudo, e as bacias de São Paulo e Volta Redonda, reconhecidas como as Bacias Tafrogênicas do Sudeste Brasileiro (Hasui et al. 1978, Riccominni et al. 1983, Riccominni, 1989).

Sobre a Serra do Mar, parte integrante do RCSB, ressalta-se o trabalho de Almeida (1998), que fornece uma perspectiva abrangente da geomorfologia da borda leste do Estado integrando diversos dados geológicos. Neste trabalho, o autor sugere uma idade de soerguimento para a Serra do Mar entre 50-60 milhões de anos, se valendo de observações geomorfológicas - relação da Superfície de Aplainamento Japi com as rochas intrusivas alcalinas datadas - e dos trabalhos de 
Gallagher et al, (1994) e Vignol-Lelarge et al. (1994). O autor cita também estudos da Petrobras (Pereira \& Feijó 1994), estabelecendo uma relação entre os movimentos tectônicos que deformaram a Superfície do Japi e foram responsáveis pela geração de grábens, com as discordâncias K120 e E10 na sedimentação da Bacia de Santos (Figura 8).

A Serra da Mantiqueira é a porção mais elevada do Sudeste do Brasil, com altitudes próximas aos $2000 \mathrm{~m}$, e configura a borda nordeste do RCSB. Consiste de um terreno tectonicamente elevado, maturamente dissecado a partir de uma superfície de aplainamento que nivela seus cimos a cerca de $2000 \mathrm{~m}$ de altitude (Almeida 1964). Chama atenção o agrupamento de serras alongadas segundo a direção SSW-NNE, representando uma forte assimetria, com as faces expostas para SW ou SE sempre mais íngremes e desnudas (Hiruma 1999)

Segundo Riccomini (1989) e Riccomini et al. (2004), são quatro os principais sistemas de falhas que entrecortam o RCSB: ENE a E-W - que acompanham a direção estrutural das antigas zonas de cisalhamento e são truncadas por outros sistemas de falhas - o sistema NNE - que são as estruturas oblíquas aos eixos das bacias, compartimentando-as internamente - o sistema NNW - falhas aproximadamente ortogonais aos eixos das bacias, com movimentação de caráter normal dominante - e o sistema WNW - movimentação essencialmente transcorrente, que condicionam altos do embasamento entre as bacias de Taubaté e Resende. 


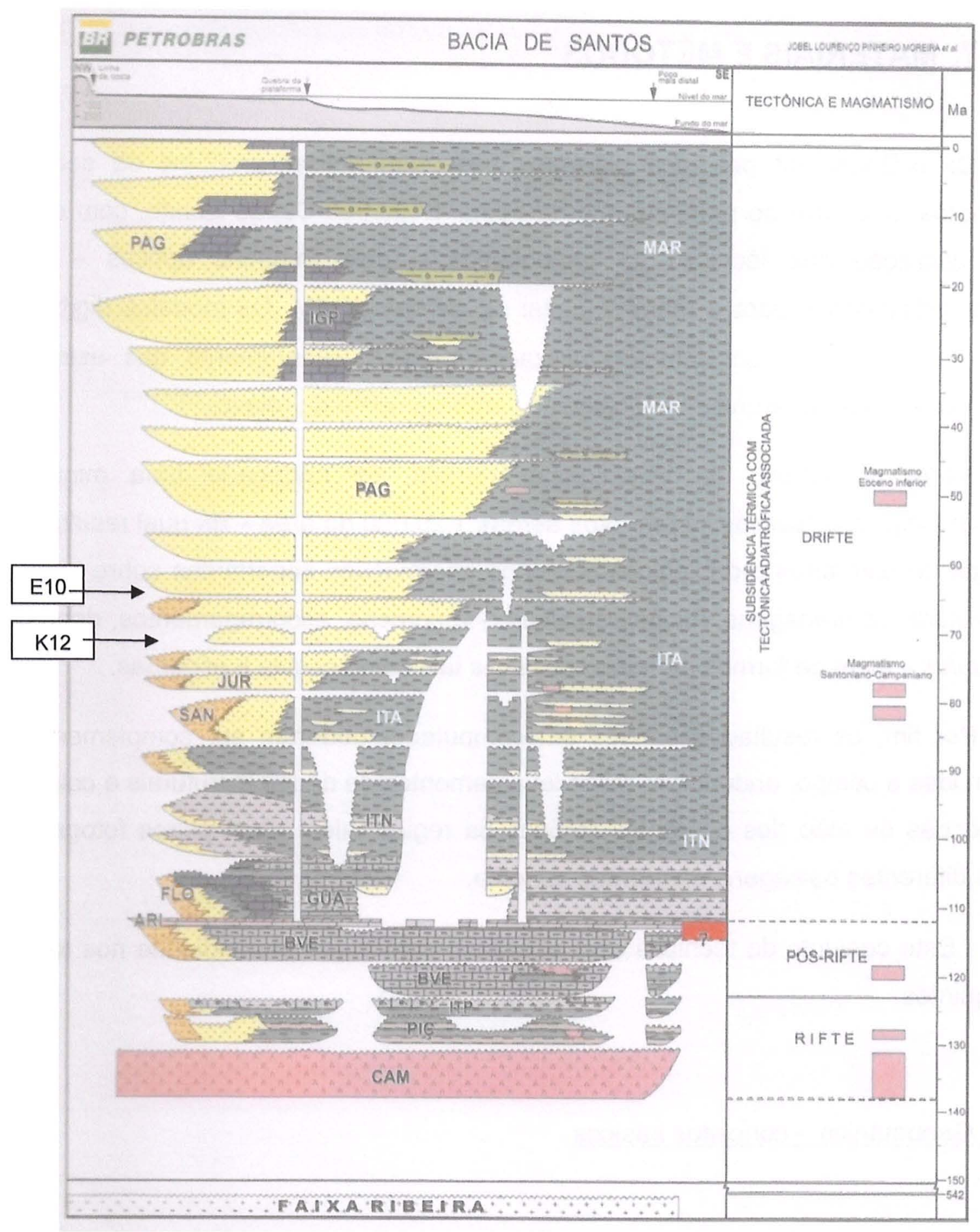

Figura 8. Coluna estratigráfica da Bacia de Santos com os intervalos K120 e E10 em destaque, relacionados aos pulsos de atividade tectônica no RCSB. Retirado de Moreira et al. (2007). 


\section{MATERIAIS E MÉTODOS}

Os métodos de pesquisa utilizados buscaram aplicar produtos de sensores remotos no auxílio ao mapeamento da Folha 1:100.000 Capão Bonito, com ênfase na utilização das técnicas de geobotânica - para imagens ópticas - e de geomorfometria - para o modelo digital de terreno SRTM. Os modelos digitais de elevação (MDE) foram também utilizados para o levantamento das estruturas principais da área, através da técnica do sombreamento de relevo.

Ainda no âmbito da investigação remota, foi carregada uma minuciosa observação estereoscópica em fotos aéreas 1:20.000 da área - da qual resultou um mapa de estruturas morfológicas contendo informações importantes sobre controle estrutural de drenagens, feições erosivas - voçorocas, escorregamentos, depósitos de talus - além de formas de relevo positivas tais como cristas e escarpas.

Por fim, os resultados obtidos em computador puderam ser complementados com idas a campo, onde foram feitos levantamentos de dados estruturais e coleta de amostras de mão dos diferentes litotipos da região, além de registros fotográficos das diferentes paisagens ocorrentes na folha.

Este conjunto de técnicas será abordado com maior profundidade nos tópicos seguintes:

\section{$\underline{7.1 \text { Geobotânica - conceitos básicos }}$}

A geobotânica refere-se ao estudo do substrato através da observação da flora, principalmente focada na busca de mineralizações e mapeamento geológico. O ser humano se utiliza de observações da cobertura vegetal como reflexo do substrato há séculos, relacionando deficiências na saúde das plantas - senescência precoce, atrofia - a ocorrências de minérios (Agricola 1556, apud Perrotta et al. 2008). 
Atualmente, a mesma ideia é aplicada ao estudo do comportamento espectral das plantas além do espectro visível ao olho humano. Sabendo como o material foliar se comporta ao longo do espectro eletromagnético (Fig.9), é possível segregar informação em imagens de sensores remotos para diferenciar áreas da floresta. Estas diferenças provêm de variações florísticas naturais, condicionadas principalmente pelo substrato imediatamente abaixo, ou seja, a geologia.

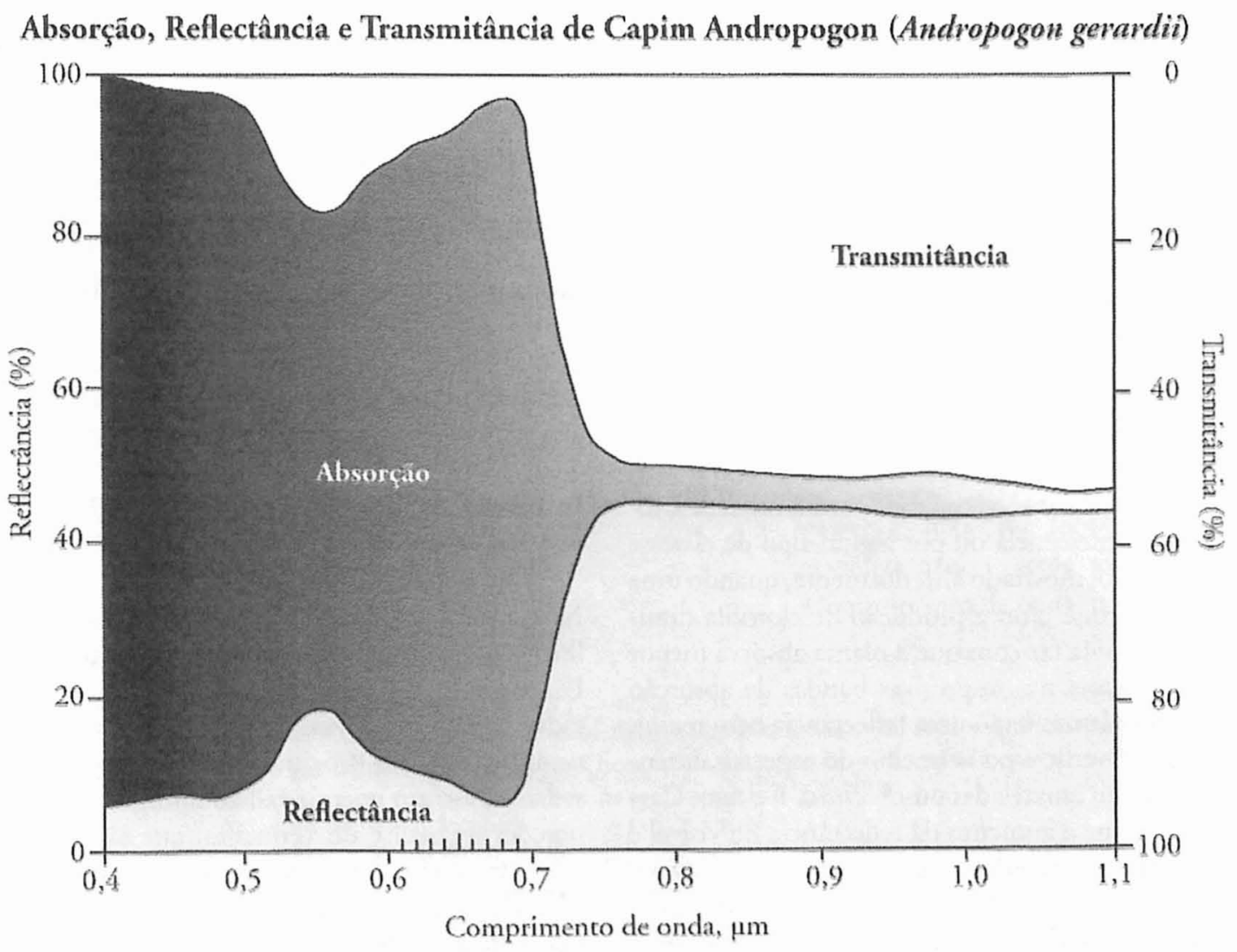

Figura 9. Espectro de absorção obtido em espectrorradiômetro de laboratório em capim Andropogon (retirado de Jensen, 2009). Notar o destaque em verde - pico de reflectância no visível - e em ciano - forte elevação da reflectância no infravermelho.

Em regiões densamente florestadas como a porção centro-norte da América do Sul e grande parte da América Central, África central e sudeste da Ásia, o acesso a afloramentos rochosos é geralmente muito difícil, seja por falta de acesso, seja pela ausência de rochas frescas devido ao clima úmido e quente. Nessas regiões o uso de imagens de satélite fica também comprometido, já que com a densa cobertura vegetal não há informação espectral referente diretamente do substrato. Nesta problemática, o uso da geobotânica por sensoriamento remoto constitui uma importante ferramenta para cartografia geológica. 
Para que se entenda esta ferramenta, deve-se primeiramente conhecer a estrutura bioquímica da folha. As folhas (Fig.10) são compostas de camadas externas conhecidas por cutículas. Estas camadas estão em contato com a epiderme, que protege o mesófilo da folha - o paliçádico (células alongadas, perpendiculares à superfície foliar) e o lacunoso - região central da folha. É no mesófilo onde ocorre a absorção da luz para a Fotossíntese.O mesófilo (ou parênquima) é formado por células ricas em cloroplastos, que são as bolsas de pigmento que conferem à folha sua cor natural - pontos verdes dentro das células do mesófilo na figura 10. O pigmento mais conhecido e mais comum é o de cor verde, a clorofila. Além deste, há diversos outros pigmentos como os amarelos e vermelhos, representados principalmente pelos carotenoides, e os azuis e roxos, os flavonoides ou as betalaínas - estas restritas apenas a plantas da ordem das Cariofiláceas. Mais pigmentos foliares podem ser observados na tabela 1.

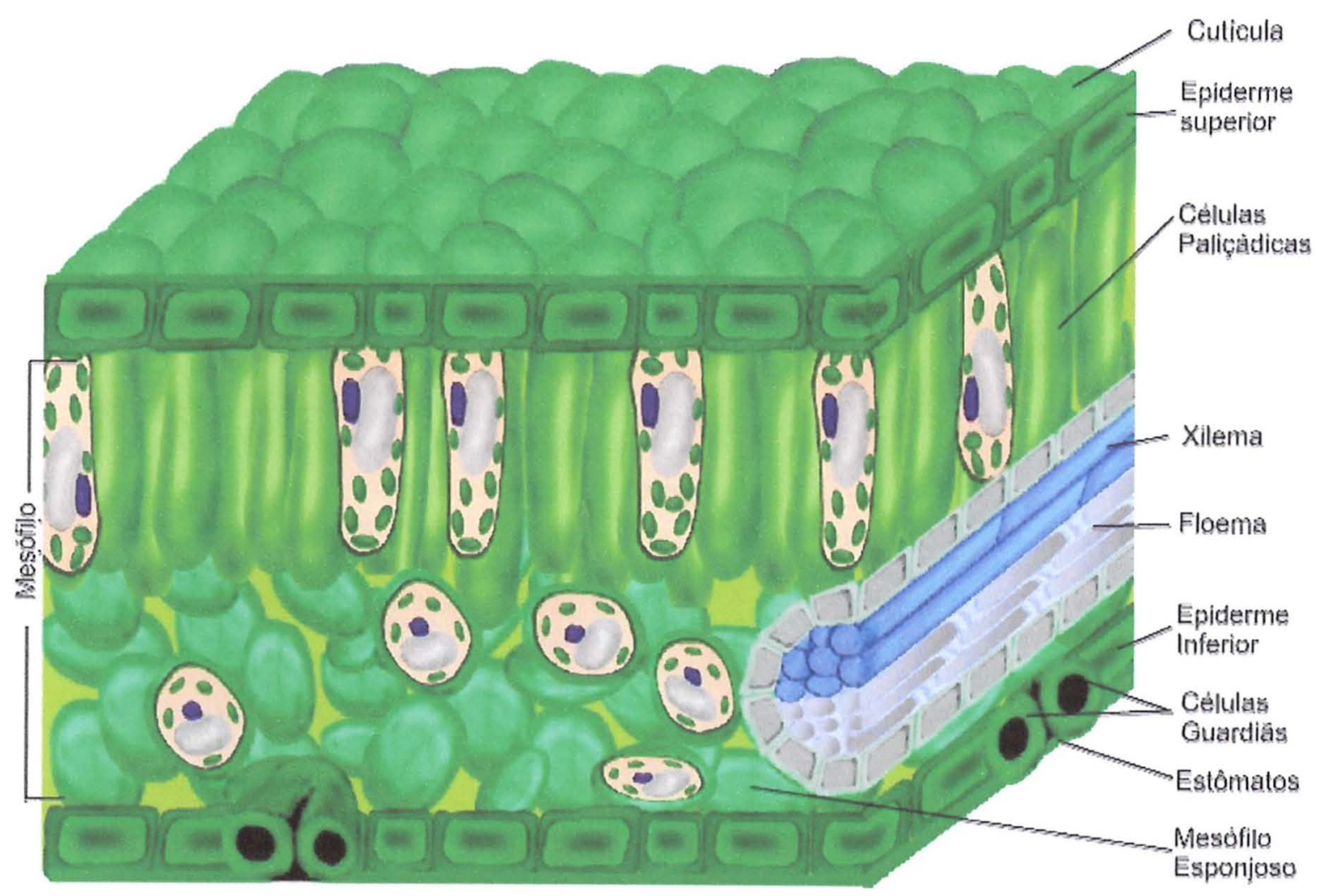

Figura 10. Modificada de (http://dendro.cnre.vt.edu/forestbiology/photosynthesis.swf, acesso em 06/2012). Estrutura celular de uma folha dicotiledônea. 
Tabela 1. Os Pigmentos foliares mais comuns. Modificada de (http://en.wikipedia.org/wiki/Ocular pigmentation\#Diseases and conditions).

\begin{tabular}{|c|c|c|}
\hline GRUPO & COR & PIGMENTOS \\
\hline Flavonóides & Vermelhos, amarelos, azuis & $\begin{array}{c}\text { Antocianina, antocianidina, } \\
\text { antoxantina, taninos. }\end{array}$ \\
\hline Betalaínas & Vermelhos e amarelos & Betacianinas, betaxantinas \\
\hline Carotenóides & Amarelo, laranja, vermelho & Carotenoides, retinóides, xantofilas \\
\hline Outros & Verdes, amarelos, infra-vermelho & $\begin{array}{c}\text { Clorofilas, alloficocianinas, ficoeritrina, } \\
\text { quinonas }\end{array}$ \\
\hline
\end{tabular}

A porção inferior da folha - epiderme inferior - acopla estruturas direcionadas à troca gasosa com a atmosfera, os estômatos. As células guardiãs são responsáveis por fechar os estômatos em caso de poeira excessiva, fumaça, e outros agentes nocivos à planta, além de regular a perda de água da folha. Por fim, toda a folha é permeada por um sistema de vasos (floema e xilema), que se interliga ao tronco e ao sistema radicular da árvore, fornecendo água e nutrientes a nivel celular.

Cada particularidade da folha, seja sua espessura, teor de água, pigmentação ou formato, interfere diretamente na maneira como a luz se comporta ao interagir com ela. Isto pode ser observado comparando espectros de três espécies bem diferentes, o carvalho da Califórnia, o arbusto-coiote e a grama (seca) - figura 11.

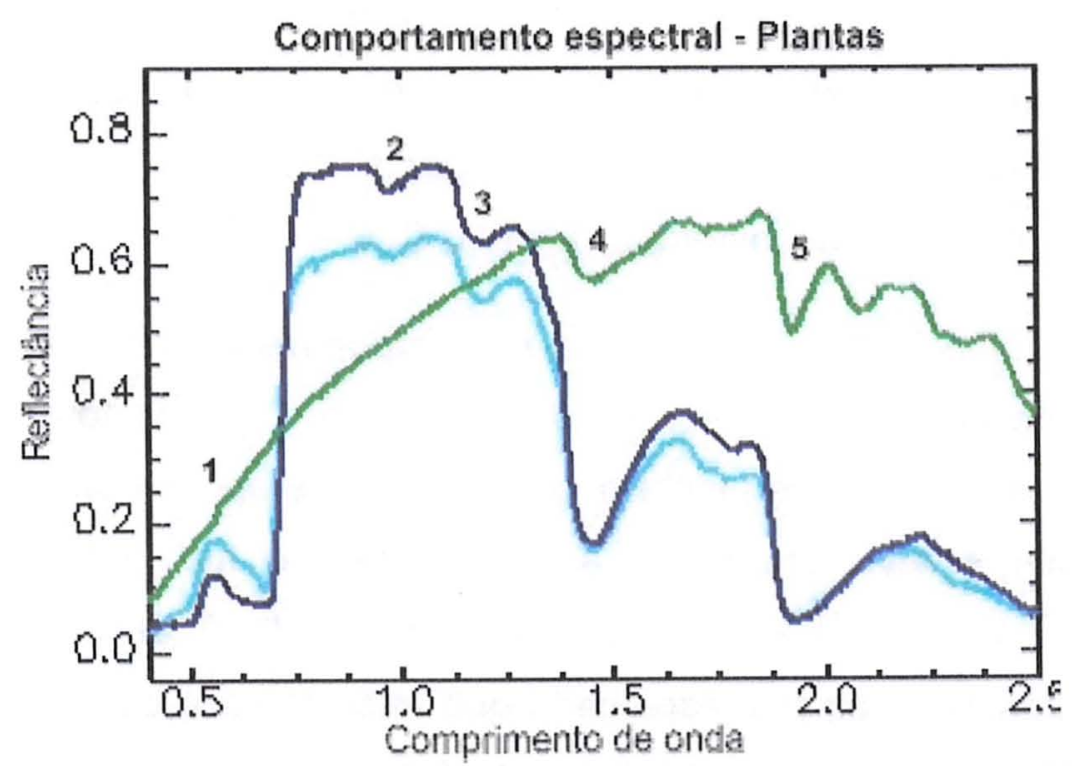

Figura 11. Plotagens da biblioteca espectral Veg_2.grn do programa ENVI 4.7 para: A. Carvalho-da-Califórnia, em azul marinho. B. Arbusto-coiote em ciano. C. Grama seca, em verde. 1 a 5 : feições do espectro, ver texto. 
De pronto observa-se que o formato dos gráficos entre as duas plantas saudáveis é muito similar, mas que a grama seca apresenta uma variação parabólica na porção até os $1,5 \mathrm{~nm}$. Isso evidencia a mudança no comportamento espectral quando da ausência de água na folha. Por sua vez, os espectros das plantas saudáveis diferenciam-se pela variação no eixo das abscissas - a capacidade de cada uma em refletir luz. Este efeito está relacionado muito mais ao formato e disposição das folhas das plantas - ver reflectância foliar aditiva, a seguir - do que às variações em suas composições químicas, geralmente muito similares.

Os gráficos de análise espectral da figura 11 mostram o comportamento de três espécies no intervalo entre o visível e infravermelho próximo. A numeração marca altos e baixos de reflectância importantes, reflexo da presença de diferentes compostos bioquímicos. O pico de reflectância (1), na região do visivel ocorre apenas nas plantas saudáveis. É a presença da cor verde (clorofila) e este é o seu pico de reflectância. O motivo pelo qual as folhas secas parecem avermelhadas também pode ser vista em (1). A ausência dos pigmentos foliares faz predominar a cor vermelha da lignina: material bioquímico associado à celulose e que confere rigidez e resistência mecânica à folha. Os rebaixamentos (2) e (3) dizem respeito à presença de água intrafoliar. Eles representam a água dentro das células das folhas e dentro de seus vasos. Desta maneira, não aparecem na grama morta, já que está seca. As bruscas quedas de reflectância em (4) e (5) também estão associadas à presença de $\mathrm{H}_{2} \mathrm{O}$. Esta água, no entanto, não está livre correndo em vasos da planta, afinal, podemos ver os picos de reflexão - mesmo que minguados - no espectro da grama morta. Esta feição se diz respeito, portanto à água contida em ligações químicas orgânicas dos componentes do lenho da árvore e da parte dura de suas folhas. Por fim, a tendência de queda de reflectância na direção dos $2,5 \mathrm{~nm}$ é reflexo de outro agente natural da atmosfera terrestre: $\mathrm{o} \mathrm{CO}_{2}$.

Outro importante fenômeno envolvido no comportamento espectral de florestas é o conhecido por reflectância foliar aditiva (Figura 12). Ele torna-se relevante quando se considera que uma planta não é formada de apenas uma folha, mas de todo um dossel, e leva em conta a quantidade de luz que é efetivamente retroespalhada por sucessivas camadas de folhas. Isto é de suma importância quando é justamente a luz retroespalhada que importa para os sensores remotos ópticos. A figura 12 mostra que camadas de folha aumentam substancialmente a 
quantidade de luz refletida - apenas duas camadas refletem $62,5 \%$ da luz incidente - e principalmente luz nos comprimentos de onda nos infravermelho próximo, onde há alta reflectância (Fig. 09 e Fig.11).

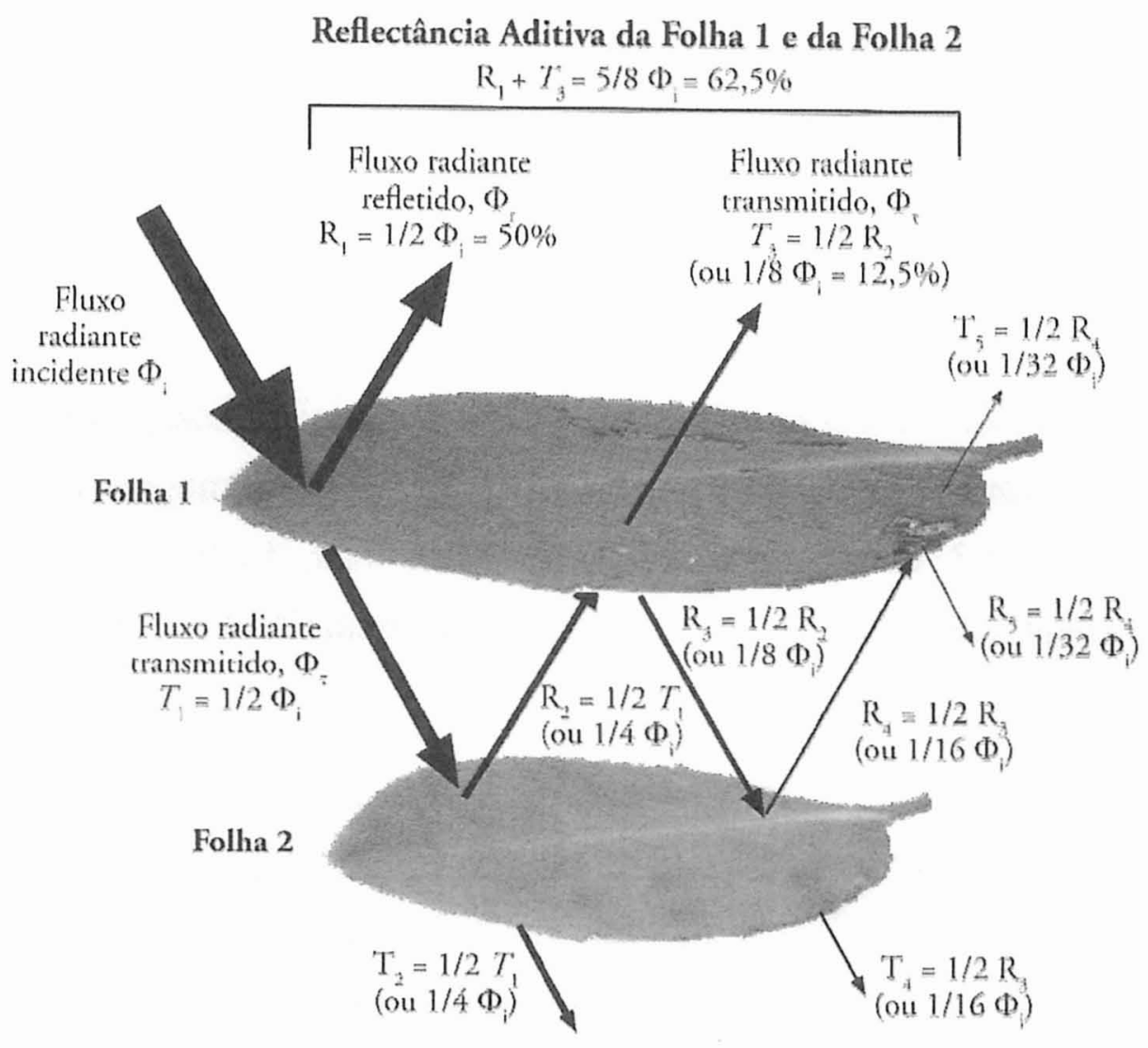

Figura 12. Reflectância Aditiva da Folha 1 e 2. Retirado de Jensen, 2009.

Toda esta luz refletida no infravermelho pela cobertura vegetal representa uma enorme quantidade de informação visual a qual não passível de observação até a década de 1940. Máquinas fotográficas no infravermelho começaram a ser desenvolvidas na $2^{\mathrm{a}}$ guerra mundial para discernir camuflagem de cobertura vegetal real em voos de reconhecimento. Atualmente, os satélites e sensores aeroportados, são capazes de absorver e registrar a luz nesta e em muitas outras porções do espectro com maior fidelidade, para, através da computação, transformar os valores digitais de reflectância (obtidos pelos sensores) em cores visíveis ao olho humano, passíveis de serem trabalhadas com sensoriamento remoto. 
A escolha dos dados, os pré-tratamentos de imagem e os passos a serem realizados para confeccionar um estudo de geobotânica podem ser observados na seção seguinte:

\subsubsection{PROCESSAMENTO DIGITAL DE IMAGENS - CAPÃO BONITO}

A região foi estudada através da análise de algumas imagens dos satélites da série Landsat. Após algumas tentativas, ficou constatado o melhor resultado de uma imagem do sensor TM (Thematic Mapper), do satélite Landsat5, obtida no GLCFGlobal Land Cover Facility (http://glcf.umiacs.umd.edu). A imagem utilizada é a de órbita-ponto 220/77, com data de aquisição 23 de maio de 1991 (NASA, 1991). O tratamento digital foi feito com programa computacional ENVI versão 4.7.

O sensor TM possui 7 bandas espectrais. As bandas 1, 2 e 3, correspondem à região do visível do espectro eletromagnético e compreendem, respectivamente, os seguintes intervalos de comprimento de onda 0,45 a 0,52 $\mu \mathrm{m} ; 0,52$ a 0,60 $\mu \mathrm{m}$ e 0,63 a $0,69 \mu \mathrm{m}$. A banda 4 capta o intervalo entre 0,76 a $0,90 \mu \mathrm{m}$, correspondente ao infravermelho próximo (NIR). As bandas 5 e 7, com intervalos de comprimento de

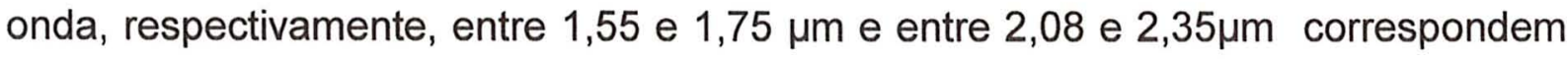
ao infravermelho de ondas curtas (SWIR). A banda 6 situa-se na região do

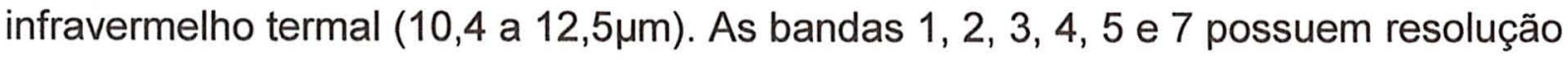
de $30 \mathrm{~m}$ e a banda 6 possui resolução de $90 \mathrm{~m}$ (http://geo.arc.nasa.gov/sge/landsat//5.html).

As imagens foram obtidas no GLCF já processadas para as correções geométricas, ortorretificação e registro cartográfico.

Foi utilizada ainda, em caráter de teste, uma imagem de um sensor similar aos levados pela família de satélites Landsat, o LISS III (Linear Imaging Self-Scaning), acoplado ao satélite hindu ResourceSat 1C. Este satélite foi lançado em dezembro de 1995 e desenvolve uma órbita síncrona ao sol a $817 \mathrm{Km}$ de altitude, e horário de passagem pelo equador as 10:30 horas. O sensor que carrega (LISS III) é capaz de

gerar 4 bandas que captam os seguintes intervalos de comprimento de onda: B2

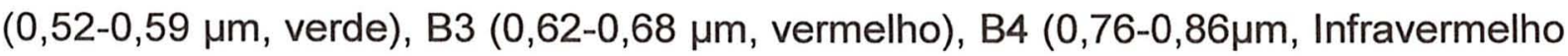


Próximo) e B5 (1,55-1,70 $\mu \mathrm{m}$, Infravermelho de Ondas Curtas), todas com 23,5m de resolução espacial (NRSA, 2004). Esta imagem foi obtida do acervo digital do INPE (www.inpe.gov.br), e foi georreferenciadas a partir da imagem obtida do GLCF.

O pré-processamento das imagens compreendeu a correção atmosférica e o georreferenciamento, quando necessário. O processamento se deu por meio de um conjunto de técnicas coerentemente combinadas, visando a discriminação dos conjuntos litológicos aflorantes, sob a denominação geral de realce por geobotânica (Perrotta et al. 2008, Almeida et al. 2009). Ambas as fases do tratamento são descritas a seguir:

\subsubsection{PRÉ-TRATAMENTO DA IMAGEM}

Para a utilização das imagens, é necessário realizar um pré-processamento que consiste em retirar o melhor possível a influência da atmosfera na obtenção dos dados espectrais. Conforme se pode observar na figura 13, a assinatura espectral da atmosfera é marcada por picos de absorção relativos principalmente à presença de gases como o $\mathrm{CO}_{2}$ e o $\mathrm{O}_{3}$, além da $\mathrm{H}_{2} \mathrm{O}$.

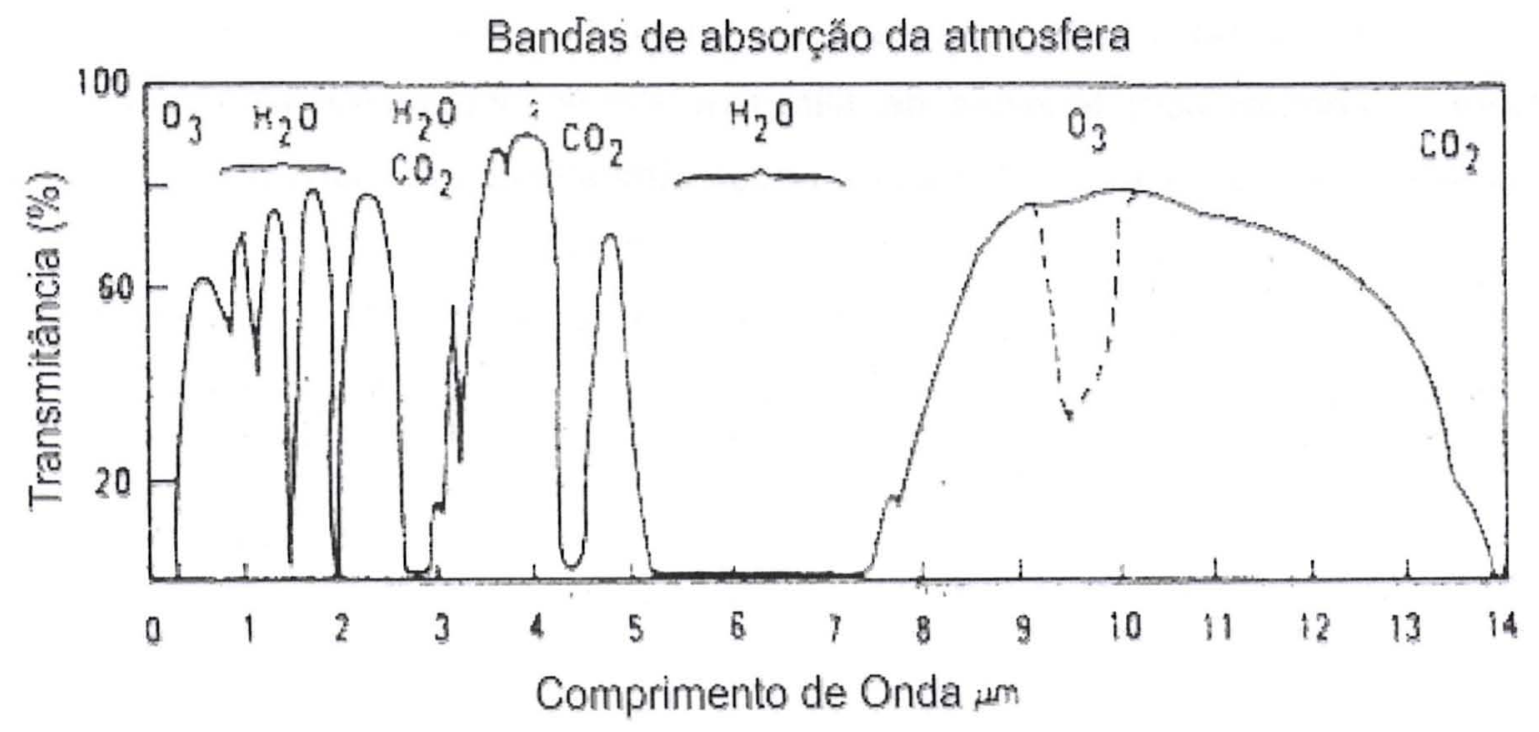

Figura 13. Assinatura espectral da atmosfera terrestre. Modificado de Sabins, 1978. 
Além dos gases naturalmente presentes na atmosfera, poeira, cinzas, fumaça, neblina e nuvens costumam ser empecilhos muito comuns aos especialistas em sensoriamento remoto. No que tange às nuvens não há muito que ser feito, a não ser a seleção das imagens com melhores condições meteorológicas. Este foi um dos maiores problemas enfrentados por este trabalho, pois as imagens sem nuvens são muito raras no acervo, limitando bastante o número de produtos disponíveis para o trabalho.

O efeito de aerossóis, cinzas ou neblina, quando forem sutis, podem ser atenuados computacionalmente pelo meio da subtração, banda a banda, dos valores excedentes devido ao espalhamento atmosférico. Para a avaliação dos valores a serem subtraídos de cada banda espectral combinam-se os métodos de remoção do pixel escuro e da quebra dos histogramas. Ele consiste em reconhecer na banda TM (7) / LISSIII (5) - que representa a região do espectro com menor influência atmosférica - as feições de corpos de água limpa ou sombras absolutas (que devem ter nível de cinza - DN - próximo a zero) e avaliar, por meio de perfis espectrais, os valores de nível de cinza das outras bandas nestas feições. Para comprovação da estimativa, os valores determinados são confrontados com a primeira quebra dos histogramas das bandas espectrais. Desta forma evita-se subestimar e, principalmente, superestimar os valores determinados para subtração.

Vale a pena lembrar que sensores mais modernos como o ASTER ou o Hyperion contam com técnicas de filtragem atmosférica muito mais avançadas. Nestes casos, são utilizadas bases de dados atmosféricos colhidos diariamente por outros satélites como os da NOAA - North American Oceans and Athmospheric Agency - que são utilizados para modelar os aerossóis contidos naquele segmento da atmosfera na hora da passagem do satélite. 


\subsubsection{REALCE POR GEOBOTÂNICA}

Com a discussão sobre a estrutura foliar, o comportamento espectral das folhas e florestas e os parâmetros técnicos dos produtos de sensores remotos utilizados nas seções anteriores, foi criada a base para possibilitar um aprofundamento sobre o tratamento computacional utilizado para a geobotânica.

O tratamento é realizado utilizando dados matriciais de sensores remotos ópticos que abranjam, minimamente, as áreas do espectro visível e infravermelho próximo. Busca-se, através dos passos detalhados a seguir, segregar a informação redundante entre bandas e salientar suas diferenças.

O procedimento adequado (Almeida et al. 2009, Perrotta et al. 2009, modificado de Almeida \& Souza-Filho 2004), consiste em:

1. Pré-tratamento da imagem, incluindo a correção atmosférica e a geração de máscara de processamento para todo o tipo de cobertura que não vegetal corpos d'água, ocupação humana, nuvens - de forma a desconsiderar esta informação na modelagem geobotânica.

2. Geração de um conjunto de razões de bandas com a banda 4 dos satélites da série andsat ou equivalente - região do espectro na qual a vegetação apresenta a maior reflectância - no numerador, e as demais, uma a uma no denominador, gerando uma série de razões de bandas.

3. Aplicação de análise por principais componentes (APC, ver seção 6.1.3.1) no conjunto de razões, com cálculo das componentes baseado na matriz de variância-covariância. O objetivo deste processamento é a decorrelação da informação redundante, concentração da informação de interesse em componentes específicas e segregação de ruídos.

4. Análise dos resultados estatísticos da APC selecionando-se as componentes mais representativas da resposta espectral desejada para combinação em tripletes que representem a variação da informação. 
5. Aplicação de filtro do tipo passa-baixa proporcional de 17 elementos nas componentes geradas para suavização de feições de alta frequência, seguida da geração de composições coloridas em RGB.

6. Reintegração da informação textural e de albedo, perdida nas razões de bandas, através da fusão por transformação IHS (Intensidade, Matiz, Saturação) dos tripletes RGB com a componente 1 (PC1) da APC sobre o conjunto de bandas originais calculada com base na matriz de correlação.

\subsubsection{Análises Multivariadas}

A análise de principal componentes (APC), processo essencial para o sensoriamento remoto por geobotânica, é um método estatístico para a realização de análises multivariadas.

As análises estatísticas multivariadas se aplicam quando da obtenção de uma grande quantidade de dados sobre diferentes variáveis em uma população numerosa. Elas utilizam conceitos como a variância e covariância entre as mesmas variáveis de diferentes indivíduos, buscando gerar coeficientes de correlação. Vincini \& Souza (2005), dos quais este trabalho aproveitou a sólida base teórica, cita que este tipo de tratamento matemático se iniciou no início do século $X X$ com os trabalhos de Pearson.

No entanto, a análise de principais componentes conforme a conhecemos surge apenas em 1933, com a denominação 'Principal Component Analysis' por Hotelling (1933). Esta técnica tem por objetivo segregar grupos de afinidades em um conjunto amostral, através da redução das variáveis reais - exclusão das menos significantes e dispersas no conjunto - e geração de novas variáveis sintéticas em número menor e menor complexidade espacial - combinações lineares das variáveis iniciais dispostas em ordem decrescente conforme suas variâncias: VAR CP1 > VAR CP2 > ... > VAR CPn (Vincini \& Souza, 2005).

O algoritmo funciona através da obtenção das matrizes de variânciacovariância ou de correlação para a extração dos autovetores e autovalores. Estas 
matrizes são calculadas a partir da organização dos dados conforme a tabela 2 , relacionando os indivíduos e as variáveis estudadas para o grupo.

Tabela 2. Organização dos dados estatísticos para a realização de análise multivariada. Extraído de Vincini \& Souza (2005).

\begin{tabular}{|c|c|c|c|c|c|c|c|c|}
\hline \multirow{2}{*}{ Individuos } & \multicolumn{8}{|c|}{ Variáveis } \\
\hline & $X_{1}$ & $X_{2}$ & $X_{3}$ & $X_{4}$ & $\ldots$ & $X_{j}$ & $\ldots$ & $X_{p}$ \\
\hline 1 & $x_{11}$ & $X_{12}$ & $X_{13}$ & $X_{14}$ & $\ldots$ & $X_{1 j}$ & $\ldots$ & $X_{1 p}$ \\
\hline 2 & $X_{21}$ & $X_{22}$ & $X_{23}$ & $X_{24}$ & $\ldots$ & $X_{2 j}$ & $\ldots$ & $X_{2 p}$ \\
\hline 3 & $x_{31}$ & $X_{32}$ & $X_{33}$ & $X_{34}$ & $\ldots$ & $X_{3 j}$ & $\cdots$ & $X_{\text {sp }}$ \\
\hline . & . & . & . & . & . & . & , & . \\
\hline . & . & . & . & . & . & . & . & . \\
\hline . & . & . & . & . & . & . & . & . \\
\hline$i$ & $X_{11}$ & $X_{i 2}$ & $X_{i 3}$ & $X_{14}$ & $\ldots$ & $X_{i j}$ & . & $X_{i p}$ \\
\hline . & . & . & . & . & . & . & . & . \\
\hline . & . & . & . & . & . & . & . & . \\
\hline$n$ & $X_{n 1}$ & $x_{n 2}$ & $X_{n 3}$ & $x_{n 4}$ & $\ldots$ & $X_{n j}$ & $\ldots$ & $X_{n k}$ \\
\hline
\end{tabular}

As matrizes de variância-covariância são configuradas conforme a matriz abaixo:

$$
S=\left[\begin{array}{cccccc}
S_{1}^{2} & S_{12} & \cdot & . & . & S_{1 p} \\
& S_{2}^{2} & \cdot & \cdot & . & S_{2 p} \\
& & \cdot & \cdot & \cdot & S_{3 p} \\
& & & \cdot & \cdot & \cdot \\
& & & & \cdot & . \\
& & & & & S_{p}^{2}
\end{array}\right]
$$

Aonde $S^{2}$ é a variância amostral das variáveis, disposta na diagonal da matriz simétrica $S$, e $S_{12} \ldots S_{1 p}$ são as covariâncias calculadas 2 a 2 para todas as variáveis de um indivíduo amostrado. As matrizes de correlação são calculadas da mesma maneira, mas ao invés de utilizarem as variáveis reais $\left(X_{1}, X_{2} \ldots X_{p}\right)$, utilizam variáveis sintéticas $\left(Z_{1}, Z_{2} \ldots Z_{p}\right)$, equivalentes às reais normalizadas. Conforme Vincini \& Souza (2005), se utiliza esta matriz quando há grande disparidade entre as 
magnitudes das variáveis observadas. Neste caso, no entanto, a diagonal da matriz é preenchida por 1 .

A partir destas matrizes, são obtidos os autovetores e autovalores. Considerando um valor escalar $\Lambda$, a matriz variância-covariância $S$ e uma matriz identidade I, temos que:

$$
|S-\lambda I|=0
$$

A resolução desta equação traz os valores dos determinantes. Deve-se lembrar que uma matriz com p variáveis apresentará em sua resolução tantos determinantes $\Lambda$ quanto forem suas variáveis. Estes determinantes são os autovalores da APC.

Associados a cada um dos valores de $\Lambda_{1}, \Lambda_{2} \ldots, \Lambda_{p}$ podemos calcular os autovetores de S através da equação vetorial:

$$
S \hat{x}=\Delta \vec{x}
$$

Da qual se obtêm os autovetores da APC. A interpretação gráfica dos autovalores e autovetores pode ser observada na figura 14. Para uma amostragem com apenas 2 variáveis, os dados se espalham em uma elipse no plano cartesiano. Os autovetores são os vetores de maior amplitude e menor amplitude do elipsoide. Seus autovalores são equivalentes aos respectivos comprimentos.

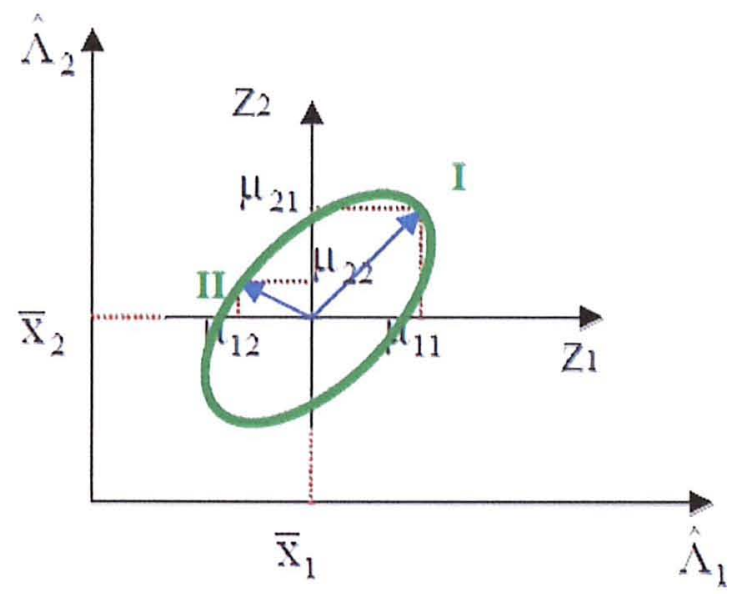

Figura 14. Representação gráfica dos autovalores e autovetores (em azul). Os autovalores são os comprimentos dos autovetores. Retirado de Valentim, 2000. 
Finalmente, a obtenção das PCs é realizada através de combinações lineares entre os autovetores e os valores das variáveis originais. São obtidas seguindo os passos da matriz adiante:

$$
\begin{gathered}
Y_{11}=x_{11} X_{11}+x_{12} X_{12}+\ldots+x_{1 p} X_{1 p} \\
Y_{21}=x_{11} X_{21}+x_{12} X_{22}+\ldots+x_{1 p} X_{2 p} \\
\cdot \\
\cdot \quad \cdot \ldots \\
Y_{n 1}=x_{11} X_{n 1}+x_{12} X_{n 2}+\ldots .+x_{1 p} X_{n !}
\end{gathered}
$$

Onde $\mathrm{Y}$ é a principal componente referente a cada caso, $\mathrm{x}$ é o autovetor para o autovalor referente a cada variável p e $X$ são os valores das variáveis originais. Quando utilizada como ferramenta analítica, restringe-se a interpretação dos dados às principais componentes mais significativas. Sabe-se da importância de cada componente em porcentagem da variância total através de equações que não serão mencionadas aqui, detalhadas em Vincini \& Souza (2005) e Smith (2002).

No caso da análise digital de imagem, esta ferramenta é utilizada através da análise pixel a pixel - cada um sendo um dos indivíduos da amostragem - dos níveis de cinza obtidos para cada banda disponível na imagem de satélite utilizada. As bandas, por sua vez são interpretadas como as variáveis originais utilizadas nesta técnica estatística $\left(X_{1}, X_{2} \ldots X_{n}\right)$. Disto resultam bandas (PCs) caracterizadas por sua correlação decrescente. Este efeito é capaz, de segregar ruídos de imagem oriundos de problemas de aquisição ou de interação do espectro eletromagnético $X$ atmosfera nas PCs finais, e de associar valores altamente correlacionáveis entre si na PC1 - geralmente enfatizando aspectos texturais (incluindo arquitetura do dossel florestal) e de relevo.

Além da aplicação em sensoriamento remoto, filtragens com APC vêm sendo muito utilizadas para softwares de reconhecimento facial (Smith, 2002). 


\subsection{Modelos Digitais de Terreno (MDTs)}

Modelos digitais de Terreno são arquivos no formato raster ou vetor, que trazem em seus elementos básicos (pixels e pontos, respectivamente), informações de cotas altimétricas. A interpolação destes valores produz um mapa contendo os contornos da topografia da área em questão. Deve-se atentar para a diferença entre os termos modelo digital de terreno (MDT) - que representa exatamente as cotas altimétricas da superfície desnuda - e modelo digital de superfície (MDS) - que considera qualquer rugosidade do terreno no valor de elevação, tal como árvores e construções.

Existem basicamente três maneiras de se conseguir dados digitais de altitude. A primeira é através de digitalização manual de mapas topográficos em programas que trabalhem com informação vetorial (CAD, SIG, etc). Esta técnica evidentemente

é bastante trabalhosa, mas apresenta maior detalhamento do relevo quando utilizada em cartas topográficas de detalhe. Para estudos em áreas grandes, em mapas de escala 1:50.000 ou maior, um método mais rápido e passivel de utilização é o imageamento por RADAR (RAdio Detecting And Ranging), o qual fornece produtos matriciais em valores de cinza correlacionáveis à altitude do terreno e em uma resolução bastante aceitável para a escala tratada neste trabalho (1:100.000). Finalmente, existe também a geração de modelos de superfície através da estereoscopia, a partir de imagens aéreas ou ainda a partir de produtos de satélite como os fornecidos pelo satélite Terra - que carrega o sensor ASTER (Advanced Spaceborne Thermal Emission and Reflection Radiometer), além de uma câmera fora do eixo normal capaz de gerar um par estereoscópico e fornecer um modelo digital de terreno.

Para este trabalho, foi utilizado um MDT obtido a partir de dados SRTM (Shuttle RADAR Topography Mission) (Farr et al. 2007), referente à área da folha Capão Bonito. Estes dados apresentam-se na forma de uma imagem raster de 8bits, em tons de cinza, com resolução espacial de $90 \mathrm{~m}$. Foram realizadas três abordagens de tratamento: a interpretação de lineamentos através de relevo sombreado (shaded relief), a realização de linhas de perfis altimétricos paralelas para a determinação de superfícies de aplainamento e a geração de um mapa de isobases. A seguir, será 
discutida um pouco sobre a tecnologia do RADAR aplicada aos estudos geomorfológicos.

\subsubsection{FUNDAMENTOS DO RADAR}

O RADAR - sigla em inglês para detecção e alcance por rádio - foi primeiramente desenvolvido em 1922 por H. Taylor e L.C. Young (apud Jensen, 2009) e era composto por um emissor e um receptor de micro-ondas montados separadamente entre as margens de um rio. Conforme os navios passavam, a transmissão de ondas era interrompida e era possivel saber a distancia do objeto em relação ao emissor. Durante a década de 1930, o RADAR evoluiu com a construção de transmissor e receptor em uma mesma unidade, melhorando em muito a resolução dos equipamentos. A consolidação do sistema como essencial para a navegação aérea e marinha veio durante a Segunda Guerra Mundial, com a construção da barreira de radares no leste e sul da Grã-Bretanha. Este avanço possibilitou à Inglaterra se defender dos ataques da Luftwaffe - força aérea alemã mesmo com inferioridade numérica e tecnológica de seus aviões.

O dispositivo é considerado um sensor ativo, ou seja, que emite a própria energia que capta. Ele trabalha com a emissão de micro-ondas e posterior detecção do eco - ondas refletidas - para o cálculo da distância, em função do tempo de envio e recebimento da onda. Se utiliza a porção das micro-ondas do espectro (geralmente entre 1 e $50 \mathrm{~cm}$ ) por serem inaudiveis ao ouvido humano e apresentarem longo alcance, ou seja, baixa interferência atmosférica (Jensen, 2009).

O imageamento por radar difere do sensoriamento ótico tanto no princípio físico utilizado - micro-ondas X luz visível - como também no resultado obtido em seu imageamento. Quando um feixe de luz atinge um objeto, a interação ocorre em um nível molecular, resultando em uma resposta da composição química do material. Por sua vez, as micro-ondas interagem com o alvo em um nivel macroscópico, respondendo principalmente às propriedades elétricas do alvo (Coimbra, sem ano, arquivo digital). 
Os radares aeroportados atuais foram desenvolvidos na década de 1950 SLAR Side-Looking Airborne Radar, em português RADAR aeroportado de visada lateral para imagear grande áreas de terreno inimigo sem se arriscar no espaço aéreo alheio, no contexto da Guerra Fria. Há dois tipos, de dispositivos: o de abertura real e o de abertura sintética (SAR), este apenas disponível em meados de 1960.

O imageamento por RADAR pode ser mais bem compreendido através da figura 15.

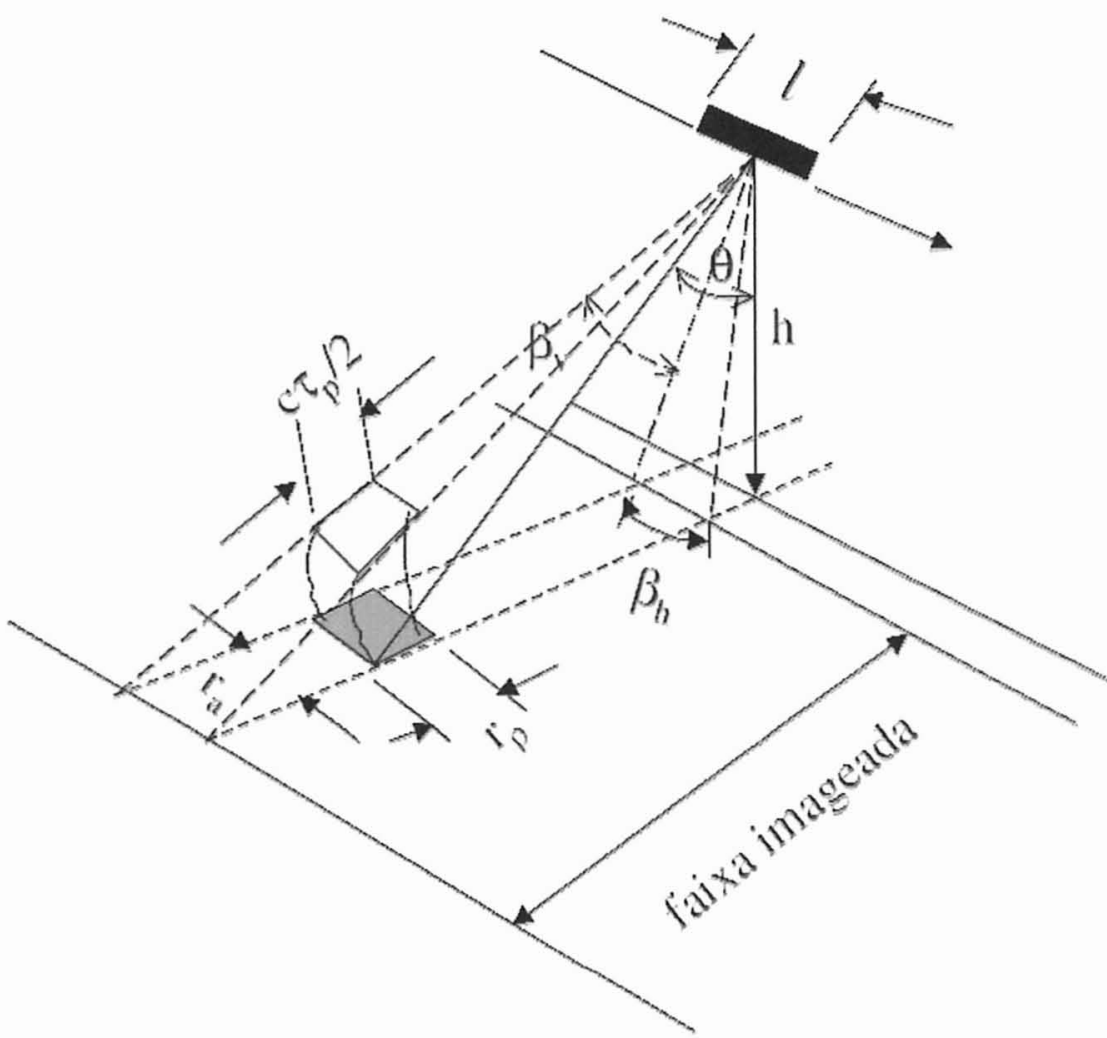

Figura 15. Geometria de aquisição de imagens de RADAR Aeroportado, retirado de Soares, sem ano, arquivo digital. c é a velocidade da luz. $T_{p}$ é a duração do pulso. $\Theta$ é o ângulo de incidência. $\boldsymbol{\lambda}$ é o comprimento de onda. $\boldsymbol{r}_{\mathrm{a}}$ se refere à resolução azimutal, e $\boldsymbol{r}_{\mathrm{p}}$ à resolução 'range'. $\boldsymbol{\beta}_{\mathrm{h}}$ e $\boldsymbol{\beta}_{\mathrm{v}}$ são os ângulos de abertura do alcance horizontal e vertical, respectivamente.

Conforme se observa na imagem acima, o RADAR utiliza feixes de ondas direcionais para a obtenção de valores de distância. Isto gera uma peculiaridade em sua aquisição de dados: a existência de duas resoluções, a resolução azimutal $\left(r_{a}\right)$ e a resolução 'range' $\left(r_{\rho}\right)$.

Estas duas resoluções são as responsáveis por gerar o tamanho dos pixels que comporão a imagem ao fim da aquisição. A resolução azimutal $\left(r_{a}\right)$ pode ser explicada como o tamanho do elemento na direção paralela à linha de voo, 
diretamente proporcional ao valor do ângulo $\beta_{\mathrm{h}} \mathrm{e}$ inversamente proporcional ao comprimento da antena I. A resolução de alcance ou 'range' é a porção perpendicular à linha de voo, sendo diretamente proporcional à duração do pulso $T_{p}$ e inversamente proporcional ao seno do ângulo $\Theta$.

Tendo em mente que a condição ótima para imagens digitais é a de menor pixel possível, buscamos então reduzir os valores de $r_{a}$ e $r_{p} . r_{\rho}$ depende apenas de fatores ajustáveis como altitude de voo e duração do pulso. Já $r_{a}$ é tanto menor, quanto maior a antena.

Durante o começo do desenvolvimento desta tecnologia (SLAR), este foi o maior empecilho: a resolução sempre estava limitada ao maior tamanho de antena passivel de ser adaptado a uma aeronave. Este problema foi contornado com a criação do SAR: o RADAR de abertura (antena) sintética.

A abertura sintética é um algoritmo computacional que simula uma antena maior do que a do equipamento, resultando em um enorme incremento de resolução e dispensando o uso de antenas muito grandes (Cutrona, 1990, Jensen, 2009).

Com os computadores atuais, é possível simular antenas dezenas a centenas de vezes maiores do que as reais, o que melhorou muito a resolução dos dados adquiridos.

O RADAR possui ainda outra característica inerente à maneira como adquire os dados. Como ele trabalha em função do tempo, porções mais distantes do sensor acabam demorando mais para retornar ao sensor e o valor de $\mathbf{r}_{\boldsymbol{p}}$ (figura 15) aumenta em direção ao alcance máximo. Isso cria um efeito de distorção nas imagens, sendo uma piora gradual de resolução da posição do sensor para a posição visada. Este tipo de disposição dos dados é conhecida por 'slant range display' ou 'disposição em alcance inclinado'. Como solução para a variação da proporção dos pixels, existe o 'ground range display' ou 'disposição em alcance de superfície' que projeta, através dos pontos de mesmo delay (mesmo tempo aferido a partir do pulso), as distâncias medidas pelo equipamento, conforme se observa na figura 16 . 


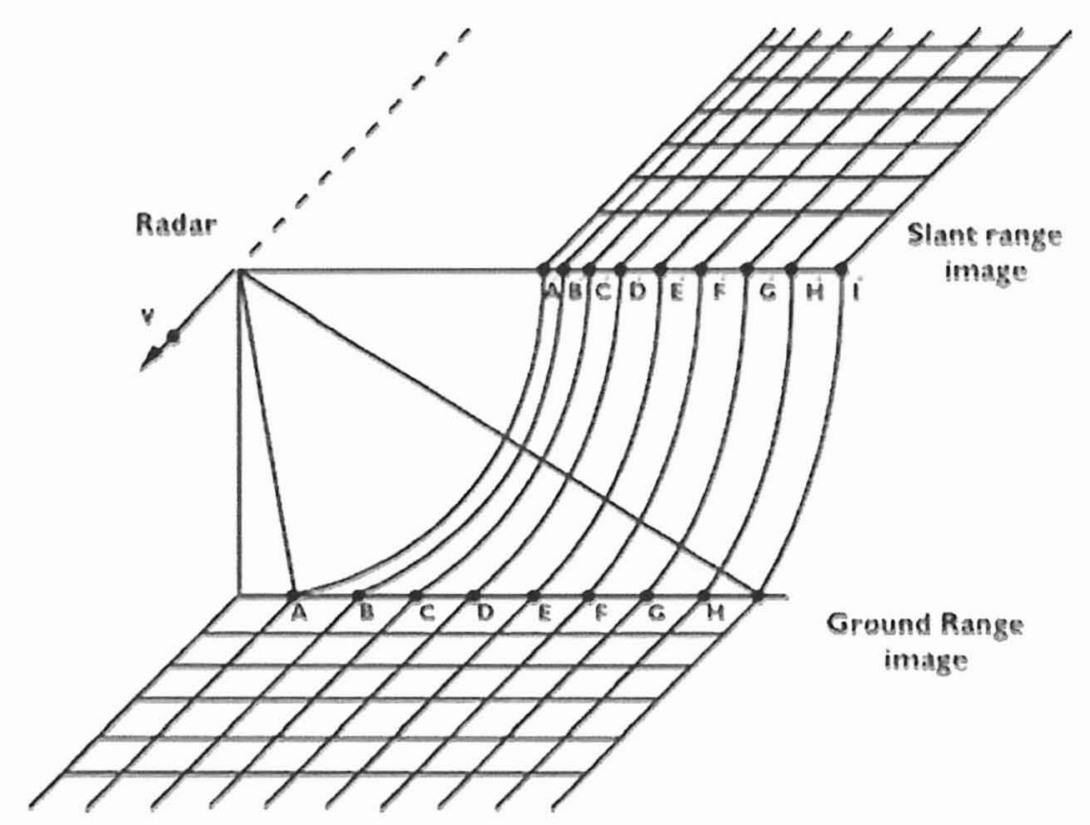

Figura 16. As duas maneiras de representar uma imagem de RADAR e suas relações geométricas. Os pontos $\mathrm{A}$ a $\mathrm{H}$ e seus respectivos $\mathrm{A}^{\prime}$ a $\mathrm{H}^{\prime}$ correspondem aos chamados pontos de mesmo delay.

Retirado de ESA, 2008, arquivo digital.

Uma maneira fácil de visualizar as diferenças entre o imageamento por radar e afotografia aérea oblíqua é demonstrada na figura 17. Nota-se a distorção dos pixels tanto na fotografia quanto no produto de RADAR em display slant range, mas a proporção de 1:1 mantida no display ground range. Esta projeção acaba por gerar um erro de posicionamento das feições, o qual é devidamente corrigido através de algoritmos computacionais melhor detalhados em ESA, 2008.

Direção de visada

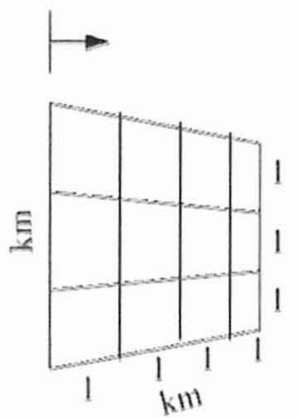

Fotogratìa aérea obliqua

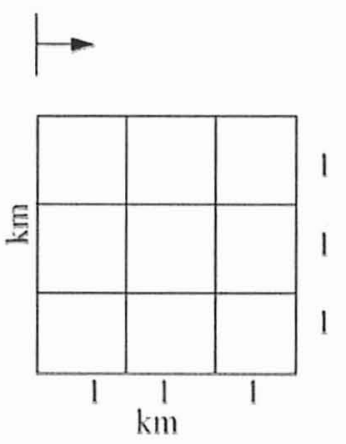

Imagem Radar Ground Range
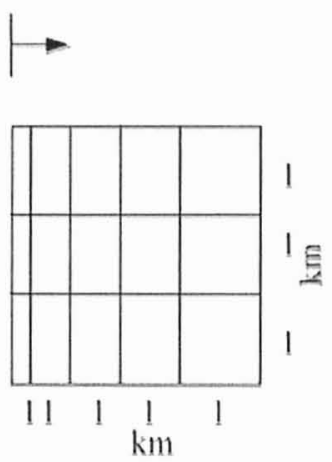

lmagem Radar Slant Range

Figura 17. Representação das distorções obtidas em três produtos remotos. Modificado de ESA, 2008. 
Por fim, são de suma importância para a aquisição de imagens por RADAR algumas características físicas da superfície terrestre. São elas a rugosidade e textura do alvo (figura 18) e as grandes variações de altitude que frequentemente geram sombras e distorções (figura 19).

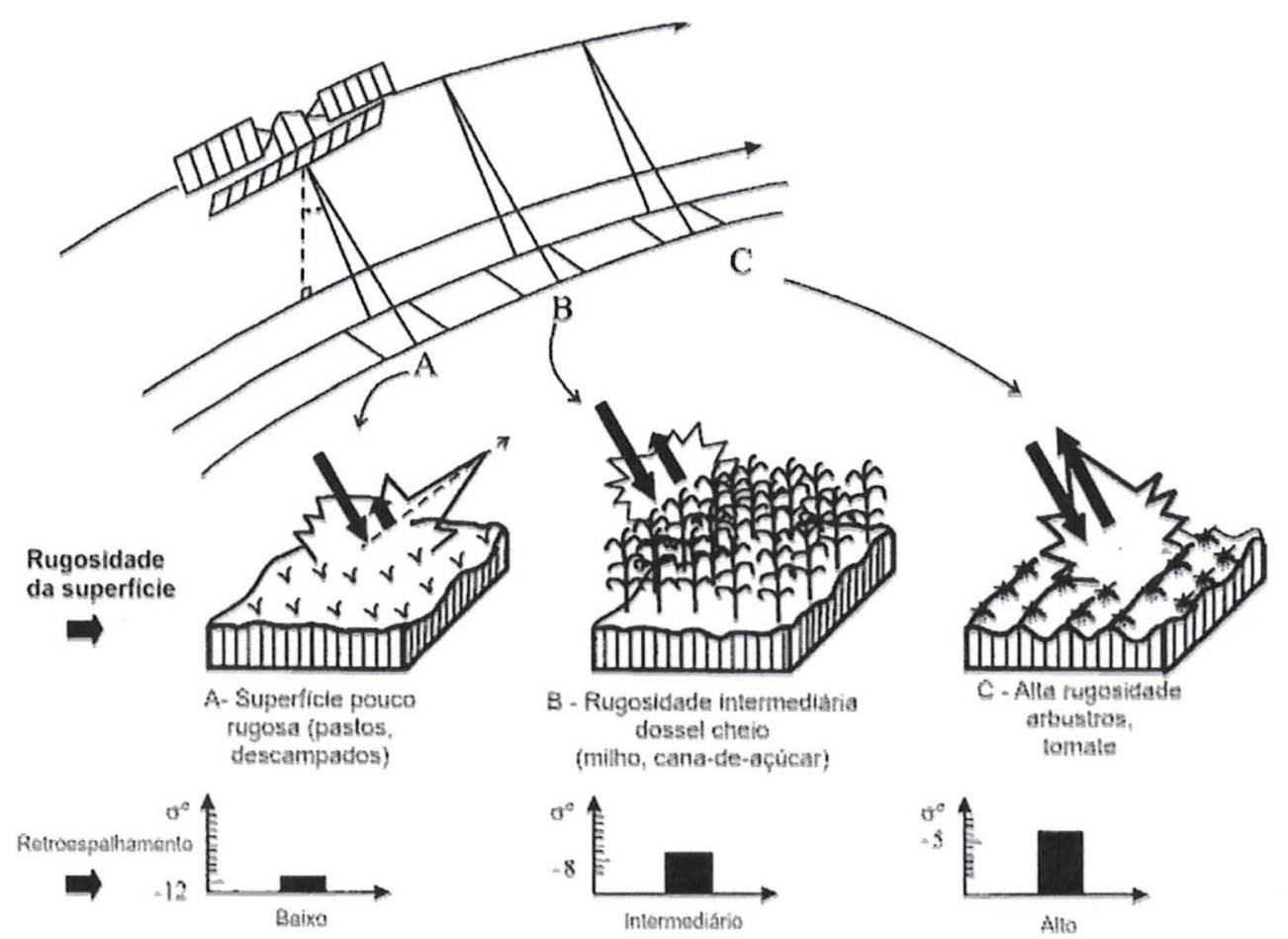

Figura 18. Retroespalhamento das micro-ondas em levantamento por RADAR. Superficies lisas tendem a funcionar como espelhos, refletindo a energia a $90^{\circ}$ do ângulo de incidência: pouco retroespalhamento. Estas superfícies tendem a aparecer com tons mais escuros no produto final. Conforme a rugosidade aumenta em $\mathrm{B}$ e $\mathrm{C}$, o retroespalhamento é maior, possibilitando ao sensor registrar a superfície com maior intensidade (tons mais claros). Modificado de Fromaggio et al. 2001.

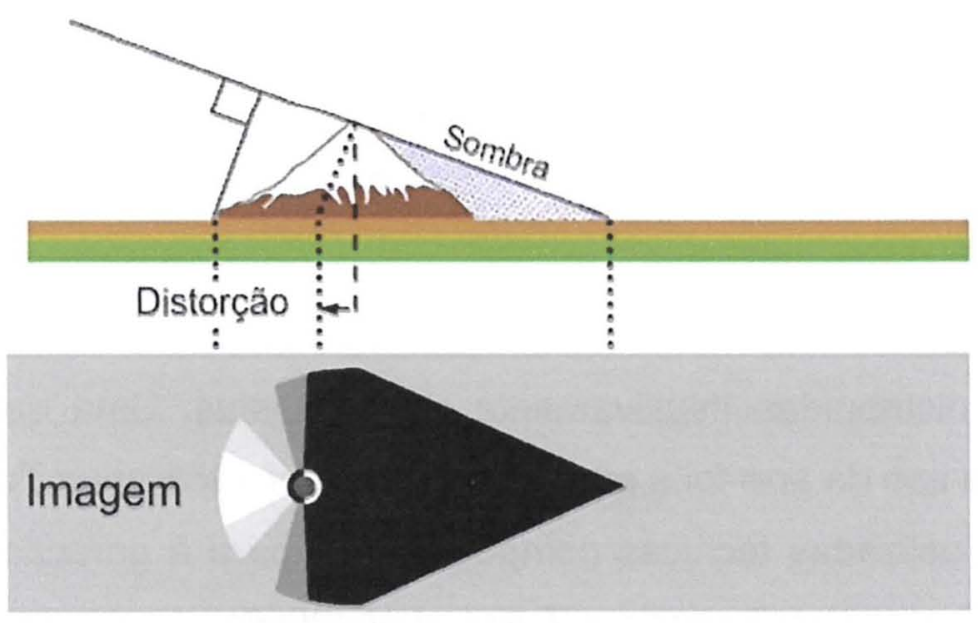

Figura 19. Distorção e geração de sombra em um RADAR de visada lateral. Modificado de ESA, 2008. 
Esta base teórica compreende os aspectos básicos do funcionamento de um levantamento por RADAR. O SRTM, produto o qual foi utilizado no presente trabalho para os estudos geomorfológicos e geomorfométricos, é um modelo digital de terreno obtido a partir do levantamento da superfície terrestre por Interferometria de RADAR através de dois sensores montados em um ônibus espacial Shuttle, espaçados por uma haste de $60 \mathrm{~m}$ de comprimento.

A interferometria de RADAR se utiliza dos princípios básicos do SAR (radar de abertura sintética) para realizar um modelo em $3 \mathrm{D}$ muito fiel, analogamente ao que se faz com pares estereoscópicos em fotografia. A Interferometria de RADAR se utiliza de duas ou mais imagens do mesmo ponto, obtidas em posições diferentes, para calcular a posição exata de um ponto do terreno, através de triangulação . A missão SRTM foi capaz de imagear quase a totalidade da Terra em uma resolução de 1 arc-seg, ou pixels de $30 \times 30 \mathrm{~m}$, excluindo-se apenas as regiões a norte e a sul das latitudes $60^{\circ}$ (Farr et al. 2007).

\subsubsection{SOMBREAMENTO DE RELEVO}

O método de sombreamento de relevo consiste na geração de uma imagem em duas dimensões com características texturais do relevo, a partir de valores de elevação. Este efeito é conseguido pela simulação da luz solar incidindo sobre as formas da paisagem, dependendo da inclinação solar , - ângulo do sol em relação ao horizonte $\left(1-89^{\circ}\right)$ - do azimute solar, - ângulo do sol em relação ao Norte (0$360^{\circ}$ ) - e do mergulho e direção de inclinação da vertente.

Historicamente, modelos de terreno sombreados eram feitos à mão, com as sombras sendo distribuídas intuitivamente pelos artistas. Uma das escolas mais tradicionais deste tipo de arte foi a escola Suiça (Imhof 1965 apud Tutic' et al. 2006). Atualmente, são utilizadas técnicas computacionais para a geração destes relevos sombreados, melhores detalhadas em Tutic' et al. (2006).

O programa ENVI@ foi o utilizado para gerar os relevos sombreados deste trabalho. Este programa foi escolhido já que traz uma ferramenta de modulação de 
realces de contraste da imagem que melhora em muito o aspecto visual do produto final.

Foram geradas quatro composições em tons de cinza, com o parâmetro da elevação solar fixo em $45^{\circ}$, e o parâmetro do azimute solar variando entre $0^{\circ}, 45^{\circ}$, $90^{\circ}$ e $315^{\circ}$, a partir do norte. A escolha de diferentes azimutes solares fornece a oportunidade de visualizar todas as faces presentes no relevo, independentemente de suas direções de mergulho (Grohmann 2004). Desta forma, obtém-se uma melhor interpretação das informações texturais da imagem, resultando na individualização de lineamentos em maior numero e em direções diferentes.

\subsubsection{PERFILAGEM ALTIMÉTRICA}

A partir do recorte do MDE da folha Capão bonito, foi realizada ainda uma série de perfis de altitude na região SE da área. Estes foram feitos com o intuito de entender melhor o escarpamento da Serra dos Agudos Grandes - porção Sul da Serra de Paranapiacaba - e a depressão do baixo curso do rio Ribeira de Iguape.

Foram criados dois agrupamentos de perfis, com espaçamento entre perfis de $5 \mathrm{~km}$ e extensão de cada perfil de $30 \mathrm{~km}$ e outro espaçado de $500 \mathrm{em} 500 \mathrm{~m}$, com 10 km de extensão. Ambos têm direção NW-SE, perpendiculares à extensão da escarpa, conforme a Figura 20. Após a obtenção dos valores de altitude ao longo de suas extensões, os perfis de cada agrupamento foram colocados em um mesmo sistema cartesiano, possibilitando a comparação entre superfícies topográficas e evidenciando estruturas basculantes de blocos.

As ferramentas utilizadas para efetuar esta etapa foram basicamente o SIG confecção das linhas de perfil geradas em arquivo vetorial (.shp). Este arquivo vetorial foi exportado para o software Surfer 11 , onde foi realizada a confecção dos perfis sobre a base de dados de altitude. Todos os perfis foram equalizados em escala vertical e horizontal e posteriormente remontados sobre o mesmo eixo cartesiano com a ajuda do software de edição de vetores Corel Draw X5. 
A interpretação das superfícies de erosão evidenciadas por esta técnica é de suma importância para o entendimento da evolução da paisagem do local. São salientadas ainda, estruturas como terraços aluvionares, cuja comparação e correlação em campo é em geral, comprometida. Ver anexo 3 - Publicações.

\subsubsection{O MÉTODO DAS ISOBASES}

O método das Isobases ou dos Níveis de Base (Base-Levels) é utilizado para relacionar a topografia com as diferentes ordens de drenagem. Segundo Powell (1875 apud Grohmann et al. 2011) um nível de base é caracterizado como o nível a partir do qual as terras secas não podem ser erodidas. De fato, o nível de base global é o mar, mas local e regionalmente, ocorrem niveis de base referentes às bacias hidrográficas atualmente instaladas. $A$ análise destes níveis pode evidenciar anomalias de drenagem muitas vezes associadas às movimentações tectônicas recentes.

Este método tem sua origem nos anos 1950, mas foi formalizado como o método das isobases pelo geólogo russo Filosofov (1960, apud Golts \& Rosenthal 1993, Grohmann 2004, Grohmann et al. 2011). Ele consiste em realizar uma interpolação entre os pontos de intersecção das drenagens previamente hierarquizadas, com as linhas de cota. Os resultados evidenciam lineamentos que fornecem controle estrutural para a instalação das drenagens, geralmente associados a movimentações recentes ao longo destes planos de falhas.

Os passos para a realização desta técnica a partir de um MDE (Figura 20) são:

1. Obtenção do MDE e extração da rede de drenagens.

2. Hierarquização das drenagens pelo método de Strahler (1952).

3. Escolha das drenagens de $2^{\mathrm{a}}$ e $3^{\mathrm{a}}$ ordem - Excluem-se as de $1^{\mathrm{a}}$ ordem por representarem quebras muito pequenas de relevo e funcionarem de maneira geral como um ruído para as estruturas maiores, e as de $4^{\mathrm{a}}$ ordem em diante por serem drenagens de caráter regional/ continental, que também acabariam mascarando as feições buscadas. 
4. Obtenção dos pontos de intersecção entre as drenagens de $2^{\mathrm{a}}$ e $3^{\mathrm{a}}$ ordem e as linhas de cota.

5. Realização de interpolação por krigagem e/ou spline (ver Grohmann et al.2011, Hutchingson \& Gessler, 1993, Marcuzzo et al. 200?), para a obtenção dos níveis base. 

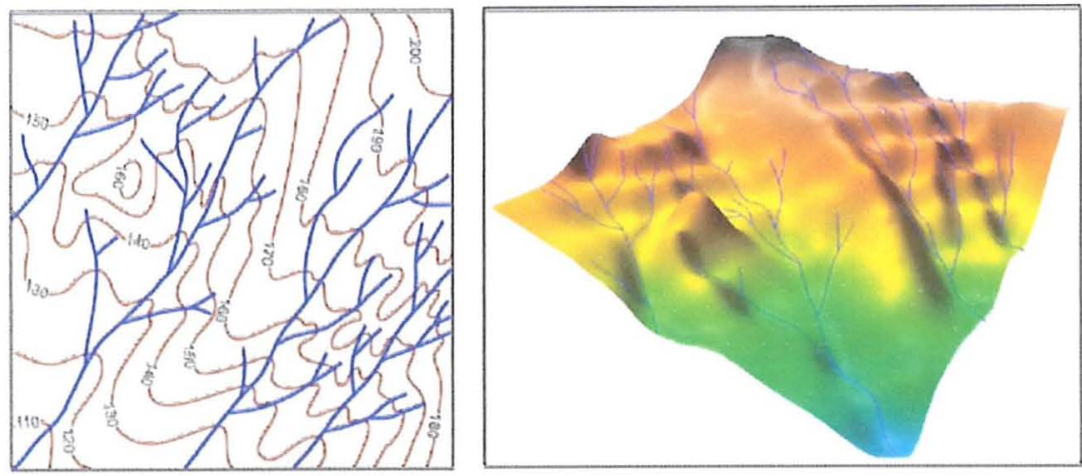

a) Linhas de cota originais e Sistema de drenagens
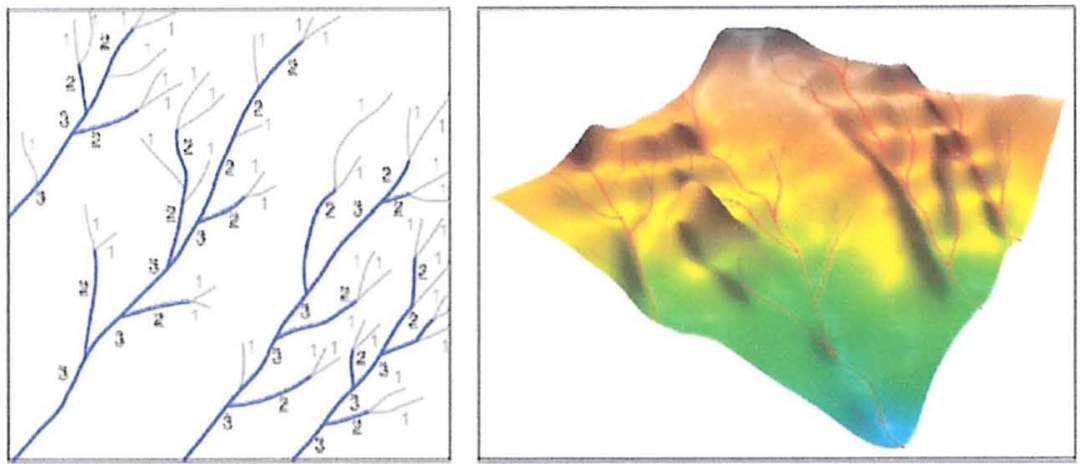

b) Escalonamento das drenagens segundo Strahler, 1962
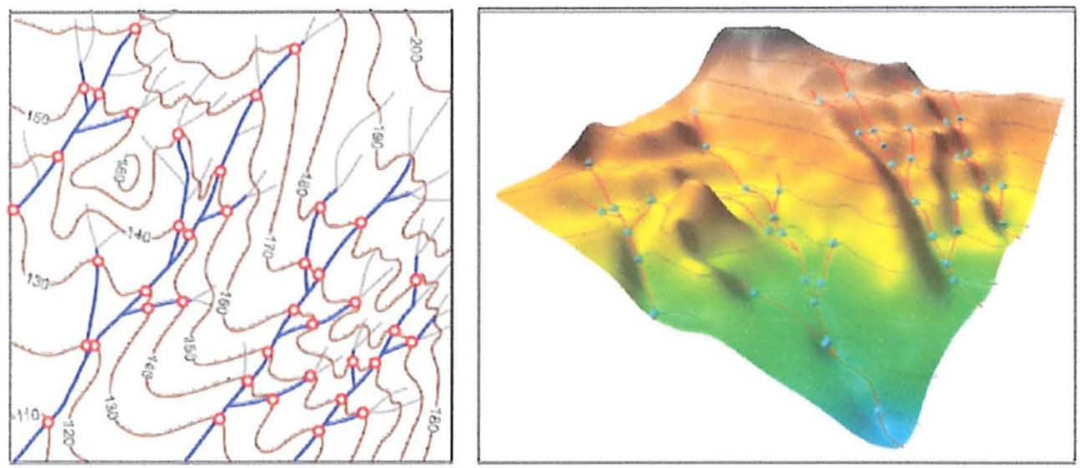

c) Intersecções dos contornos com as ordens de drenagem selecionadas,
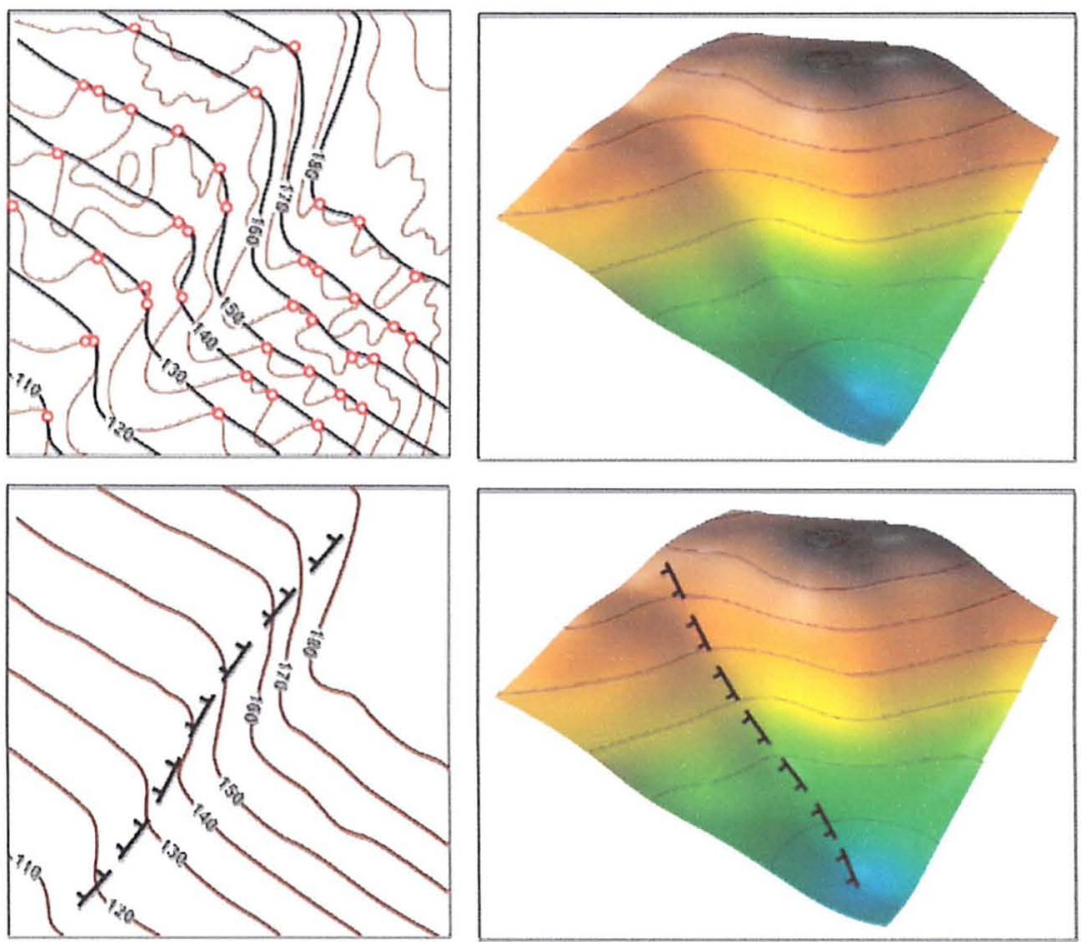

d) Interpolação das cotas dos dos pontos de intersecção.

Figura 20. Etapas do tratamento do MDT segundo o método de isobases. Modificado de Grohmann et al. 2011. 


\subsection{Mapa morfotectônico}

Como maneira de melhorar a interpretação das estruturas e das feições geomorfológicas da área de estudo, foi realizado um mapa das feições erosivas voçorocas, anfiteatros - e morfológicas - escarpas, cristas. A nomenclatura e estilo de mapa foi baseada nos trabalhos de Hiruma (2007) e Hiruma et al. (2010).

Este mapa foi confeccionado a partir de fotografias aéreas em escala 1:60.000 de junho de 1965, gentilmente cedidas do acervo da CPRM Superintendência Regional de São Paulo (ANEXO). Foi utilizado um estereoscópio de espelho para realizar a fotointerpretação em papel de alta transparência.

As fotos foram georreferenciadas uma a uma através da plataforma SIG ArcGIS, com base nas folhas cartográficas do IBGE 1:50.000 Capão Bonito (SG-22X-B-III-1), Taquaral (SG-22-X-B-III-2), Ribeirão Itacolomi (SG-22-X-B-III-3), e Serra do Aboboral (SG-22-X-B-III-4). Os mapas de fotointerpretação também foram referenciados um a um seguindo as marcas fiduciais das fotografias previamente locadas no espaço.

O mosaico das fotointerpretações pode então ser digitalizado também através da plataforma ArcGIS e exportado em arquivo vetorial tipo shapefile (.shp). O produto final pode se utilizado sobre qualquer outra base cartográfica de interesse.

Este trabalho é bastante demorado, pois requer muita concentração e toma tempo - extração das feições à mão seguida de georreferenciamento sistemático. No entanto, a recompensa vem com um produto final de alta qualidade e com a capacidade de observar o relevo de uma região em uma escala bastante didática.

\subsection{Levantamentos de Campo}

Os levantamentos de campo foram realizados em duas etapas, a primeira executada em novembro/2011 - campo de reconhecimento regional na área - e a segunda, realizada em maio de 2012 - perfis de caminhamento. 
Foram feitas amostragens de maneira sistemática e o levantamento de medidas estruturais de foliações e fraturas, utilizando-se de uma bússola tipo Clar. No presente trabalho, serão focadas principalmente as medidas de fraturas, obtidas em toda a área de estudo. Com a projeção destas medidas em estereogramas de hemisfério inferior, é possível caracterizar as principais famílias de fraturas da área, relacionando-as aos movimentos tectônicos recentes.

Todas as amostras de mão foram catalogadas e fotografadas. Fotografias de amostras importantes ou tomadas como litologia-tipo seguem em anexo a este trabalho no CD (anexo 04) - contém todos os registros fotográficos das amostras com os nomes dos pontos do afloramento, em concordância com os dados em shapefile da plataforma SIG.

\section{RESULTADOS E DISCUSSÕES}

Seguem adiante os resultados obtidos para todas as frentes de trabalho da pesquisa. Serão abordados os resultados para a o sensoriamento óptico por geobotânica, para os tratamentos aplicados ao SRTM, para a fotointerpretação, bem como as descrições de campo, incluindo descrições e fotografias das amostras de mão mais representativas de cada região da folha Capão Bonito.

Esta seção trará ainda discussões aprofundadas para cada resultado obtido das técnicas supracitadas. As abordagens serão iniciadas na escala de observação remota e serão sucessivamente ampliadas até a escala de afloramento, na discussão dos dados de campo. Esta distribuição dos dados visa construir um conhecimento sólido sobre a geomorfologia e a geologia da região estudada, de forma linear e elucidativa. 


\subsection{Geobotânica em imagens multiespectrais}

O tratamento por geobotânica foi inicialmente aplicado em toda a área florestada da folha Capão Bonito. Foram recortadas as regiões de pastos e de ocupações humanas e mantida a faixa central da folha. Esta primeira abordagem apresentou algumas falhas condicionadas por particularidades do terreno em questão.

Primeiramente, a região apresenta uma considerável variação topográfica, entre os cerca de $50 \mathrm{~m}$ sobre o nível do mar na parte SE, já na região do Baixo Ribeira, até a proximidade da cota $950 \mathrm{~m}$ na região do Planalto Atlântico. Esta variação influi diretamente na atmosfera da região já que, em sua porção SE, mais baixa e bastante próxima ao oceano Atlântico, a quantidade de neblina e aerossóis é sensivelmente maior. Esta diferença na atmosfera impede uma correção atmosférica homogênea para toda a imagem. Assim posto, a segregação visual obtida entre estas duas áreas não se dava essencialmente pelo tratamento digital aplicado à imagem, mas por sua pronunciada diferença atmosférica na data de aquisição.

Em segundo lugar, a área estudada apresentava três regiões muito distintas texturalmente uma da outra. A porção norte, dominada pelos litotipos do Grupo Açungui é fortemente marcada na direção NE-SW por sua foliação metamórfica, gerando cristas alongadas nesta direção. A porção central, representada pelo batólito de Agudos Grandes, apresenta menor rugosidade, sendo esta essencialmente creditada à fraturas dominantemente NW-SE. Por fim, a porção Sul, região dominada por terrenos mais abatidos onde ocorrem litologias pertencentes ao Grupo Açungui, aqui em maior grau metamórfico, e ao Complexo Embu. Esta localidade apresenta um relevo com morros residuais bastante arredondados, que se erguem em meio aos depósitos sedimentares terciários e quaternários (aluviões do rio Ribeira de Iguape).

Esta variação textural sem dúvida agiu de maneira positiva quando da separação visual entre estes três domínios, mas no que tange a individualização de rochas dentro de cada domínio específico através da geobotânica, a rugosidade do terreno acabou mascarando diferenças sutis e impossibilitando a segregação visual entre litotipos de menor variabilidade. 
$\mathrm{Na}$ porção central, houve mais um empecilho. A presença de uma extensa fazenda de pinheiros (pinus elliotti) acabava por gerar influências significativas na estatística das principais componentes, impedindo uma segregação melhor entre as litologias presentes.

Podemos observar um dos resultados preliminares rapidamente através da Figura 21. Ela representa o tratamento por geobotânica que foi realizado primeiramente, sem os cuidados implementados na segunda tentativa. Observa-se, de maneira geral, uma boa segregação entre os grandes grupos rochosos - em geral creditada à grande diferença textural e atmosférica entre os três diferentes domínios - além de uma grande mancha de cor vermelha escura bem na porção central da imagem.

Inicialmente, esta porção escurecida despertou bastante curiosidade. A mancha se dispõe discordantemente à direção esperada para qualquer litologia da região (NE-SW), mas aparece alongada segundo a direção NW-SE, direção esta relacionada ao alinhamento de Guapiara. Para sanar a dúvida do que poderia ser esta anomalia, foi feito um controle de campo. A mancha era reflexo de uma extensa plantação de pinus eilliotti, conforme pode ser visto na figura 22 .

É interessante observar ainda que na porção norte da imagem, ocorrem manchas em tons rosa mais claras, intercaladas com porções vermelhoamarronzadas, de cor similar à resposta obtida pela plantação de pinus. O controle de campo permitiu afirmar que o método foi capaz de identificar as regiões de plantação de eucalyptus sp., em tons mais claros, em detrimento das plantações de pinus, em tons mais escuros. Esta separação torna-se óbvia ao observar a arquitetura do dossel de cada uma destas espécies. Os pinheiros com suas folhas aciculares e sua geometria em cone, são muito diferentes dos eucaliptos lenhosos, com grandes folhagens planófitas, diferenças estas, que podem ser detectadas pelo sensor em órbita. Esta simples demonstração serve para ressaltar a funcionalidade e competência do método da geobotânica, já que apresenta uma alta capacidade de individualização de dosséis florestais. 


\section{Imagem ETM+ Geobotânica PCs $4 / 2$ (R) $4 / 5$ (G) $4 / 3$ (B)}

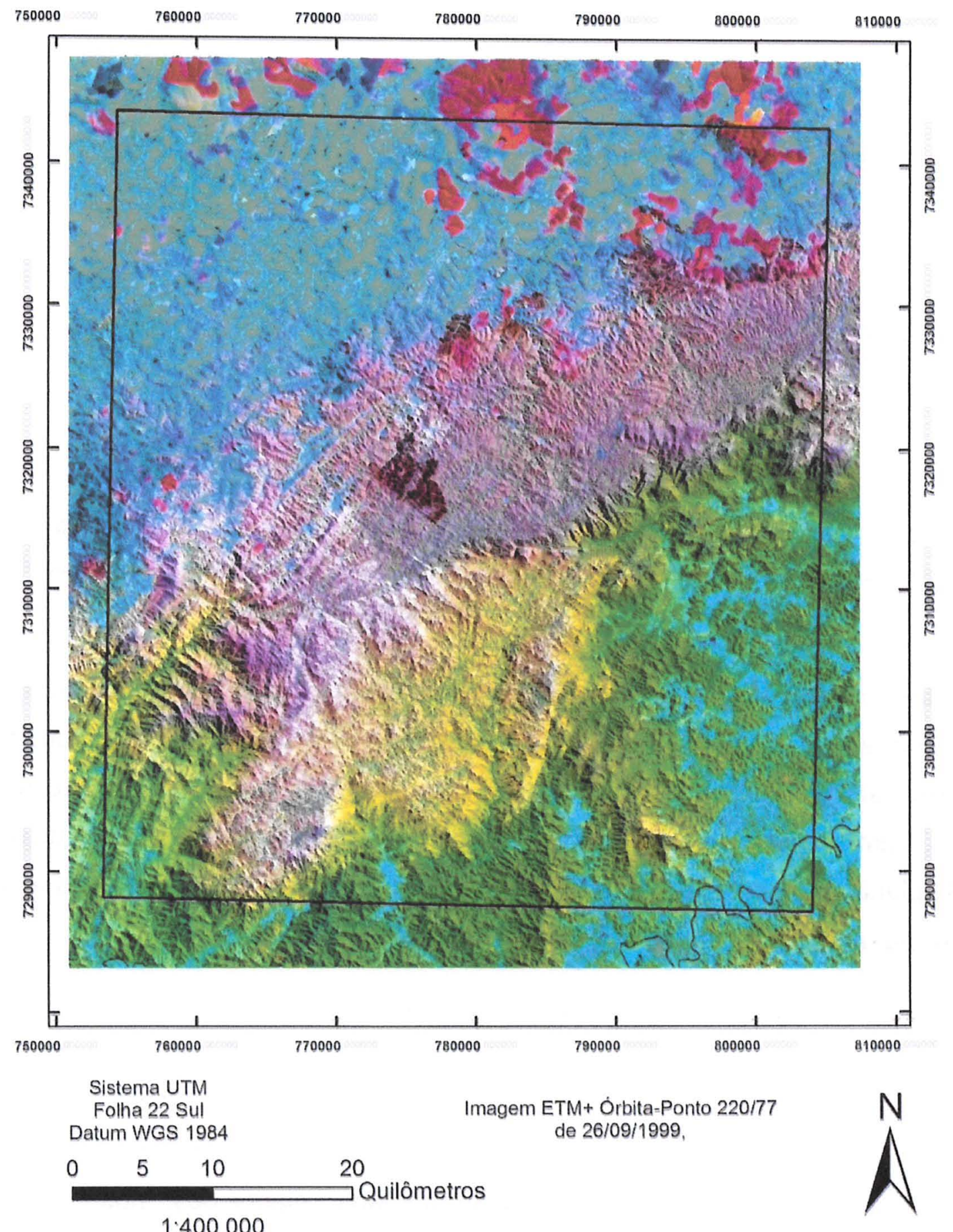

Figura 21. Tratamento por geobotânica preliminar sem a individualização das porções norte, central e sul. Notar ao centro a grande mancha vermelho-acastanhada (pinus) e, na borda norte, outras manchas em cor rosada (eucalyptus). 


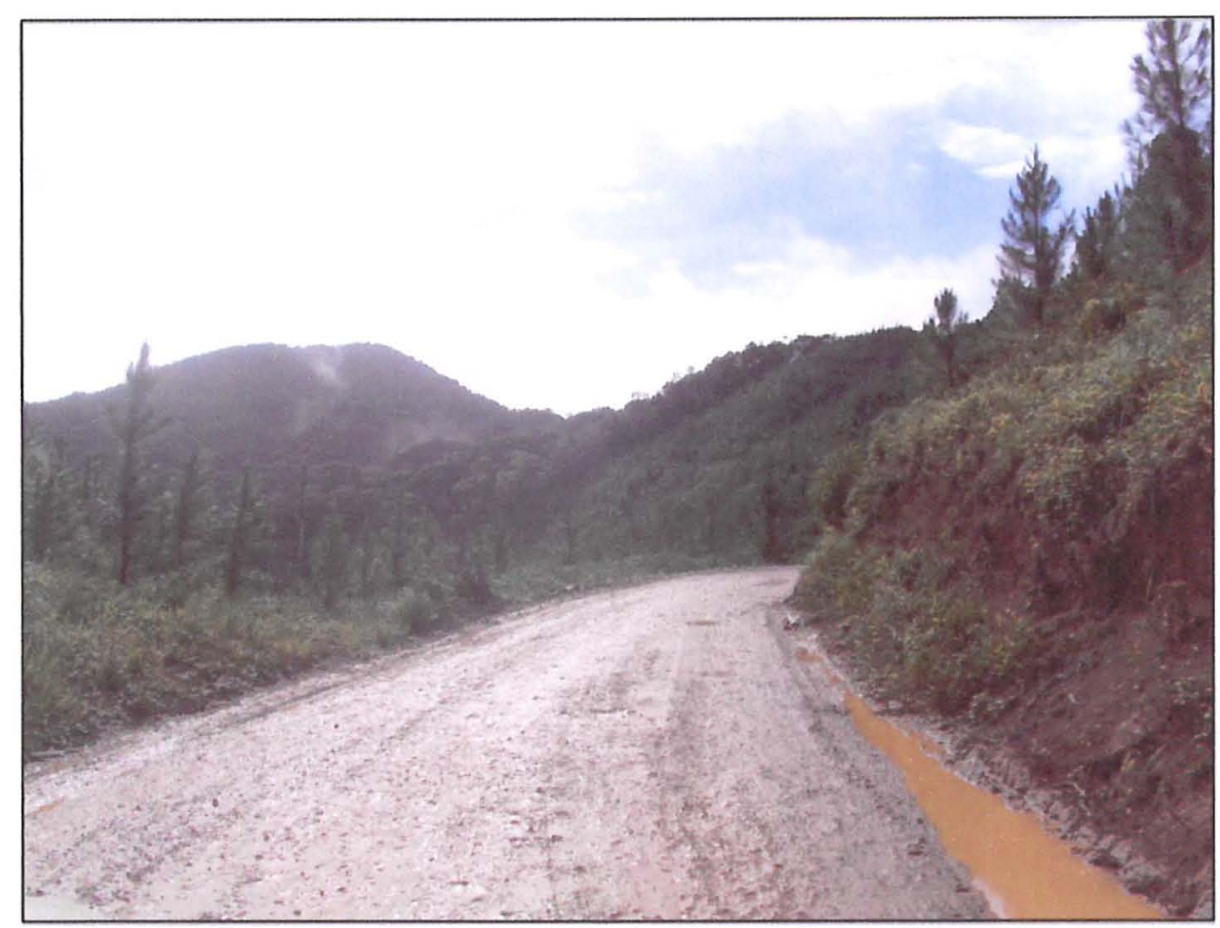

Figura 22. Controle de campo. Limite da Plantação de eucalipto do Grupo Orsa, com área ainda florestada por mata atlântica (ao fundo). A grande diferença entre a estrutura dos dosséis é fortemente evidenciada pelo tratamento em qeobotânica (fiqura 10).

Buscando a melhoria no tratamento digital, passou-se a considerar as peculiaridades locais, através do recorte da imagem de satélite em três domínios: norte, central e sul. Esta divisão buscou minimizar os efeitos das diferenças texturais entre si, bem como das diferenças atmosféricas presentes na área. Além disso, a área de plantio de pinus elliotti foi suprimida da estatística da imagem através de sua inclusão na máscara de valores nulos.

Esta abordagem alcançou melhorias quanto à segregação de litotipos de uma mesma unidade, já que limitou a área do processamento digital e possibilitou a análise de uma estatística, por assim dizer, mais 'pura', utilizando exclusivamente a resposta da cobertura vegetal, sem interferência de discrepâncias exógenas variações atmosféricas bruscas, ocupação humana, plantações, rios e corpos d'água, grandes variações texturais e de altitude.

Foram realizadas ainda, análises estatísticas dos autovalores e autovetores das principais componentes geradas. Esta análise gerou duas tabelas de autovalores e autovetores - uma para cada tipo de principal componente utilizada: covariância ou correlação - para cada porção analisada (norte, central e sul), 
totalizando 12 tabelas. A compilação dos dados estatísticos e a comparação de seus valores foi de suma importância para a escolha das principais componentes utilizadas nas composições de falsa-cor finais.

As tabelas apresentadas a seguir apresentam os valores obtidos para os autovetores das análises de principais componentes realizadas nas imagens. Cada região apresenta duas tabelas de autovalores e duas tabelas de autovetores, uma dupla para cada tipo de APC realizada (correlação ou covariância). As áreas delimitadas em cores mostram, em pelo menos um dos sensores, altos valores de autovetores. A divisão de cores é utilizada apenas para facilitar a separação das regiões, sendo a área norte em azul, a área central em verde e a área sul em amarelo. 


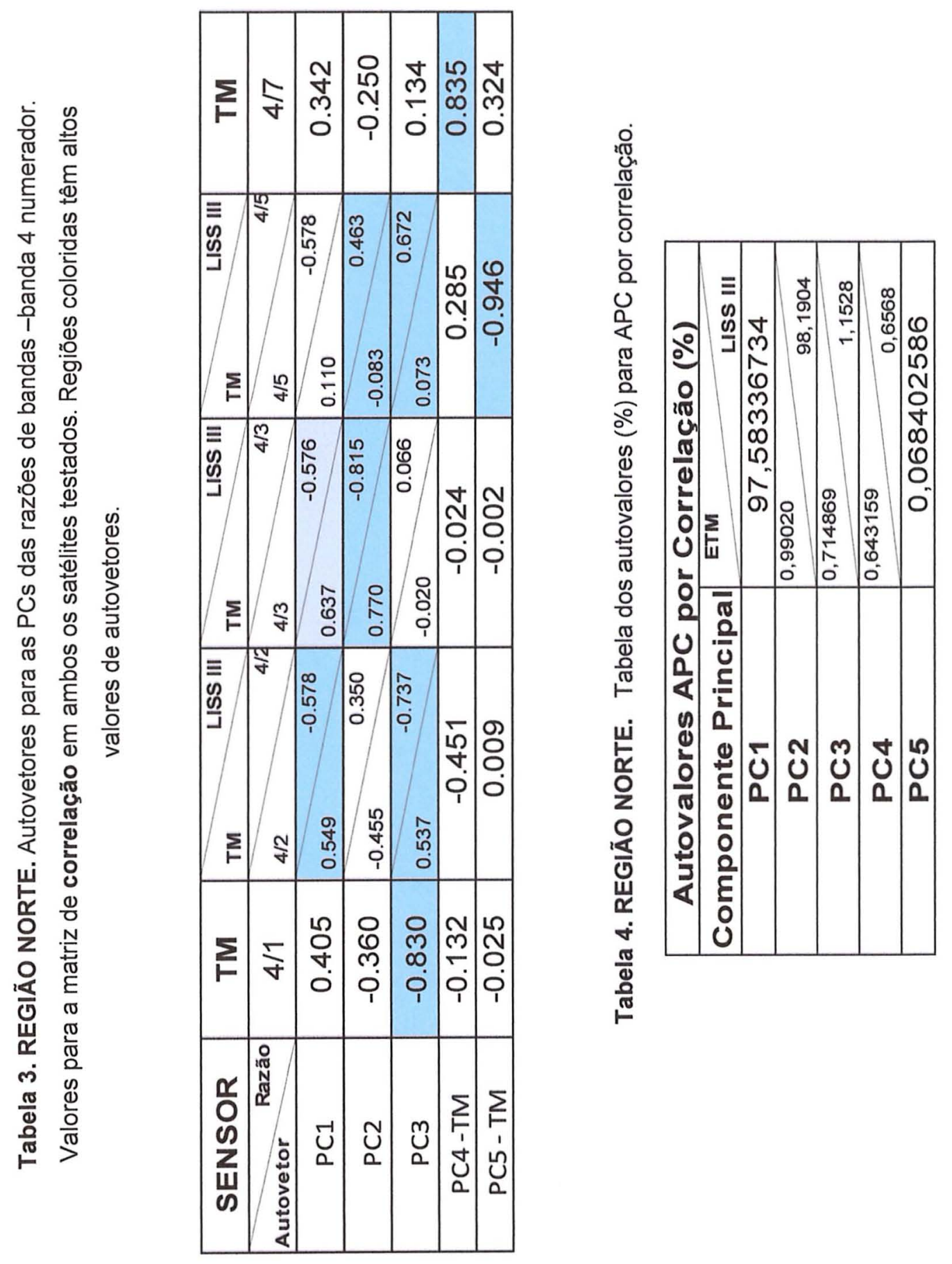




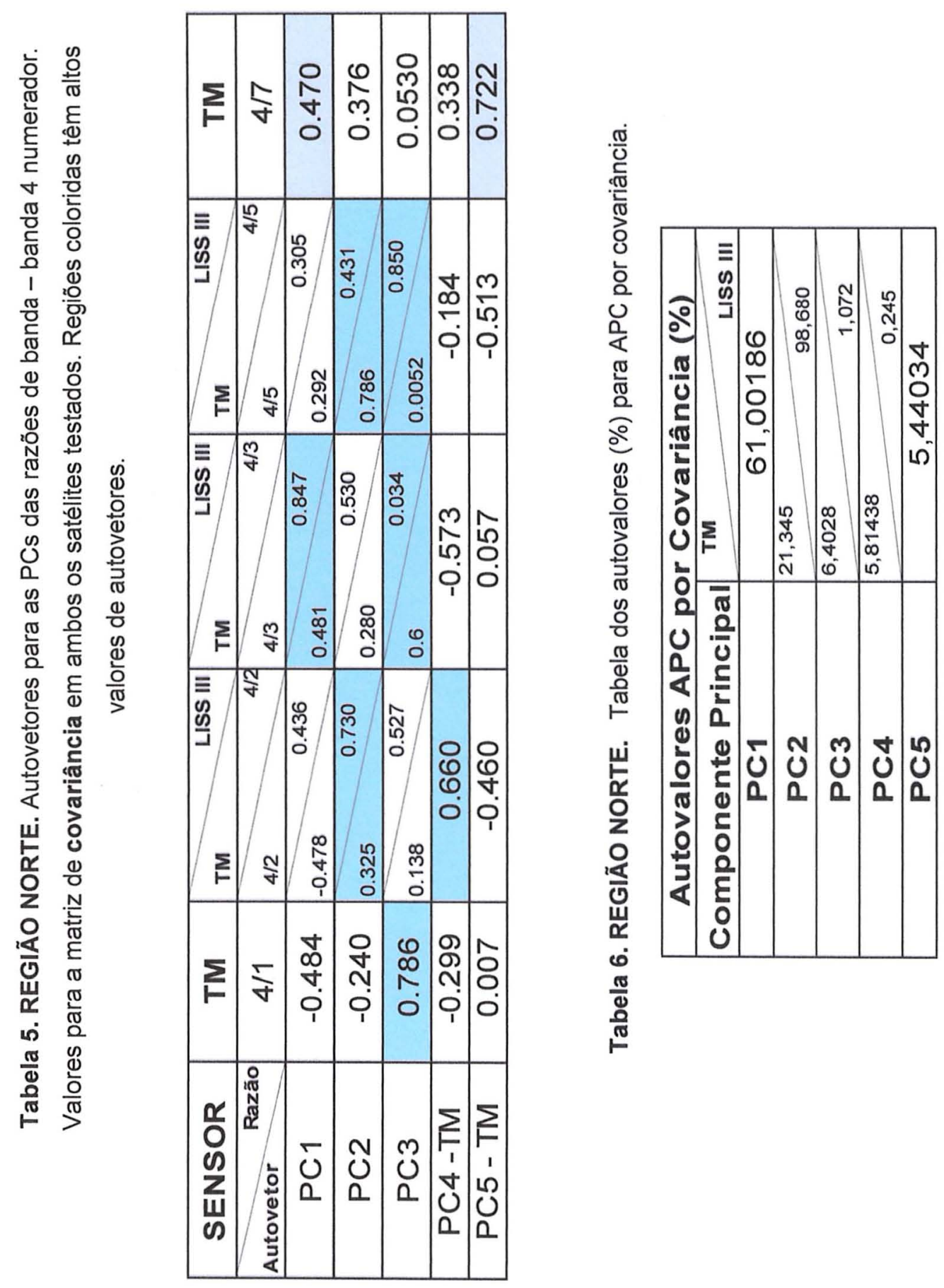




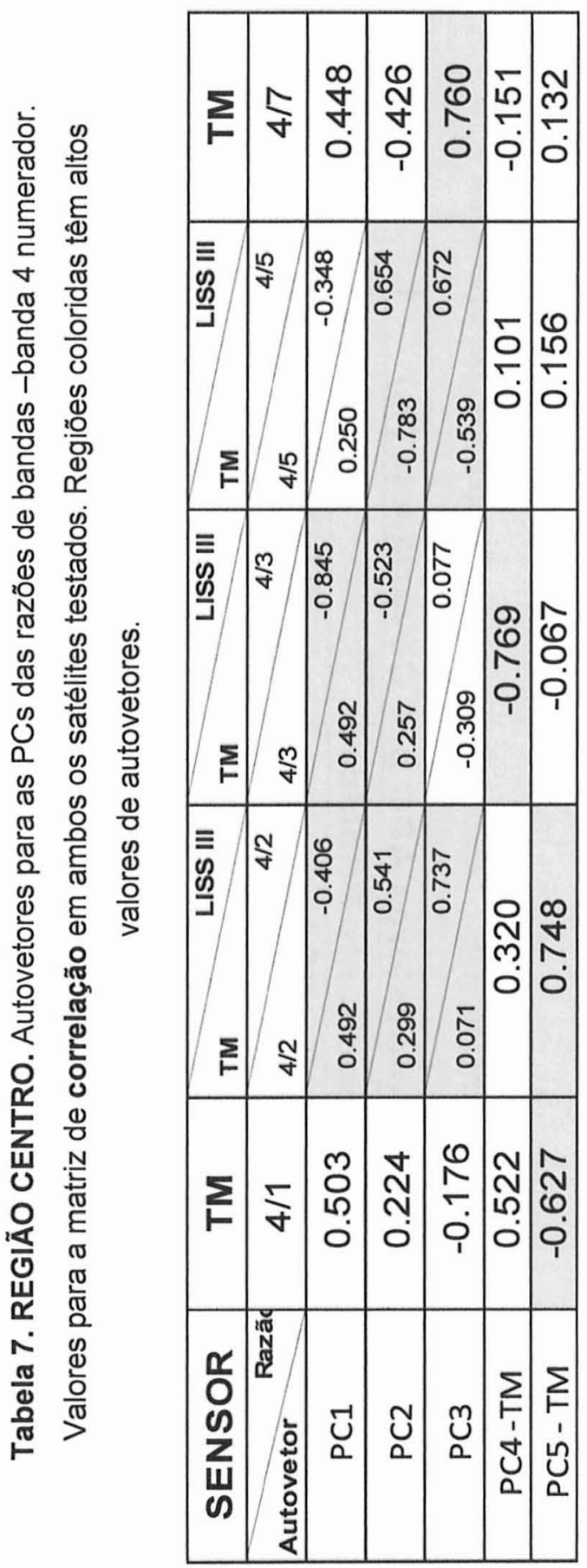

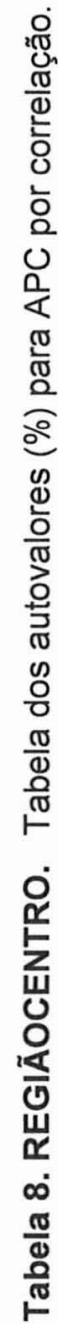

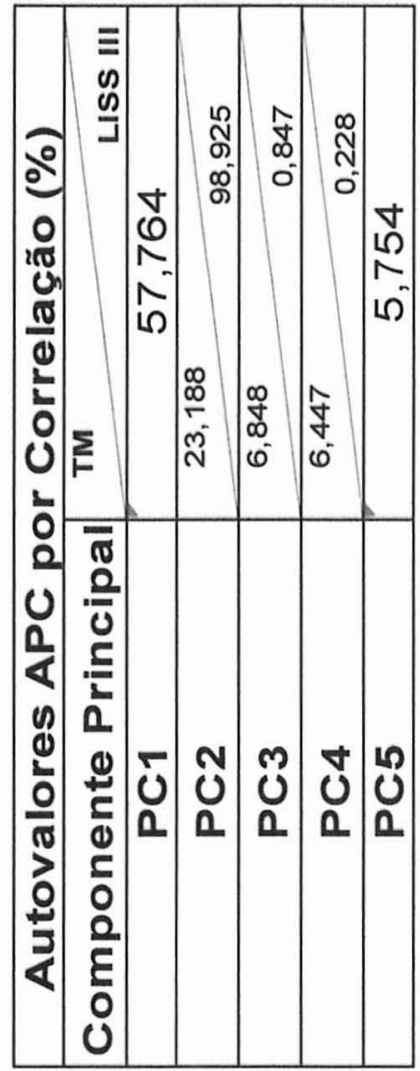



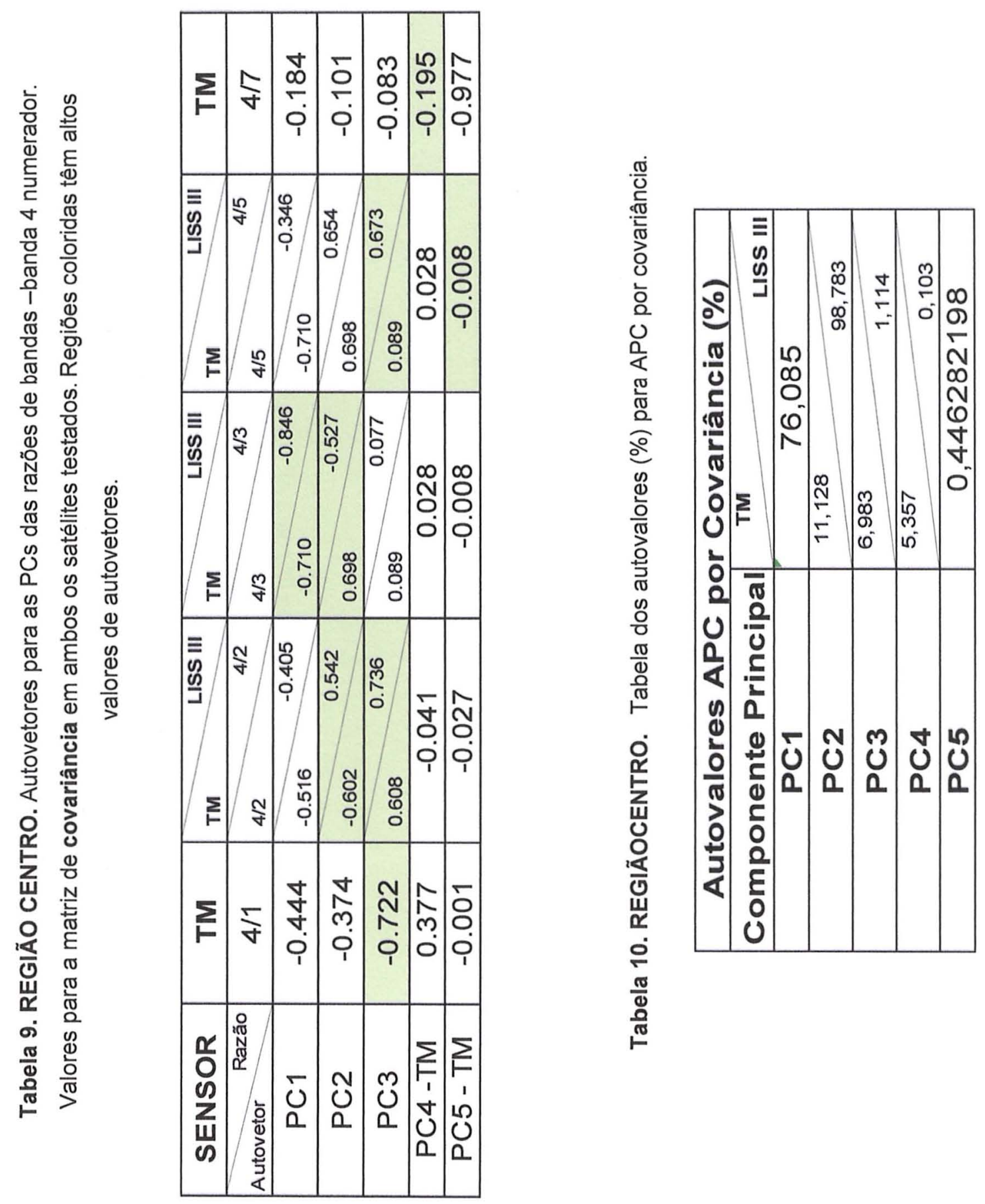


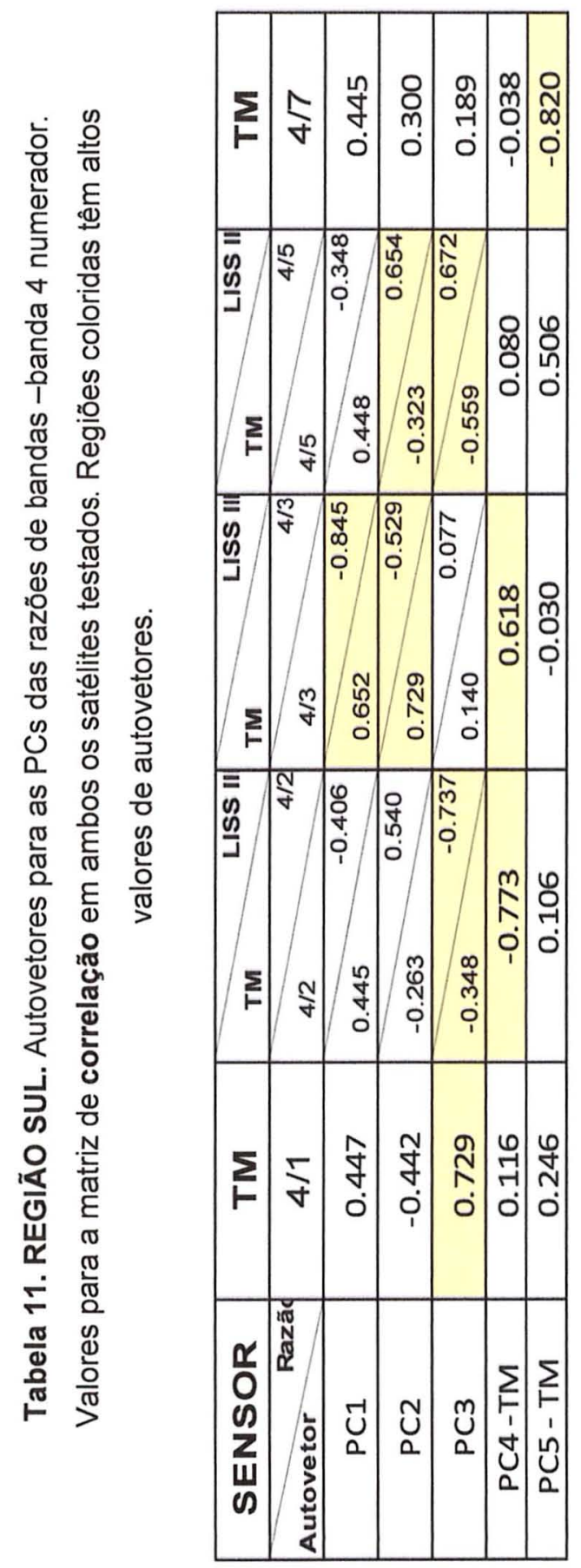

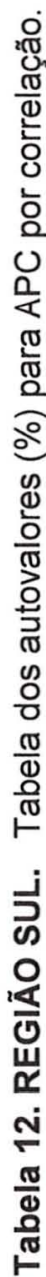

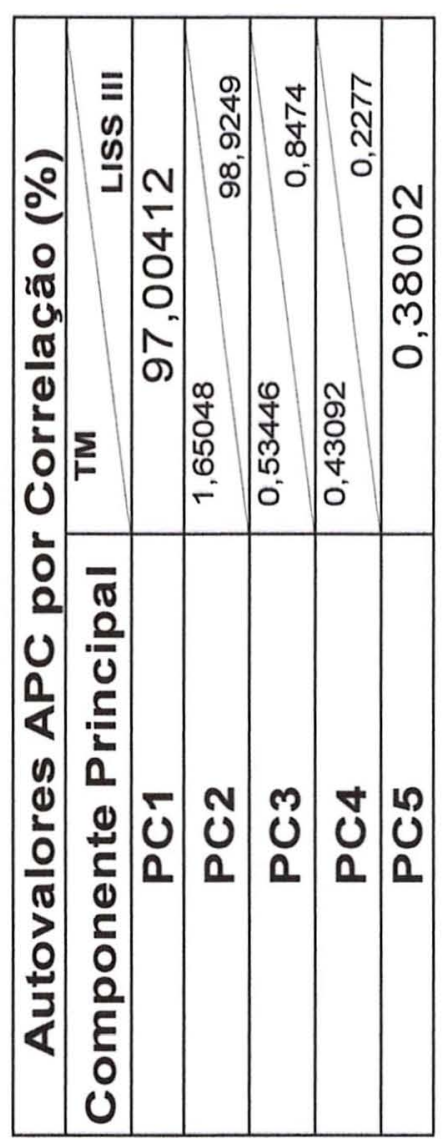



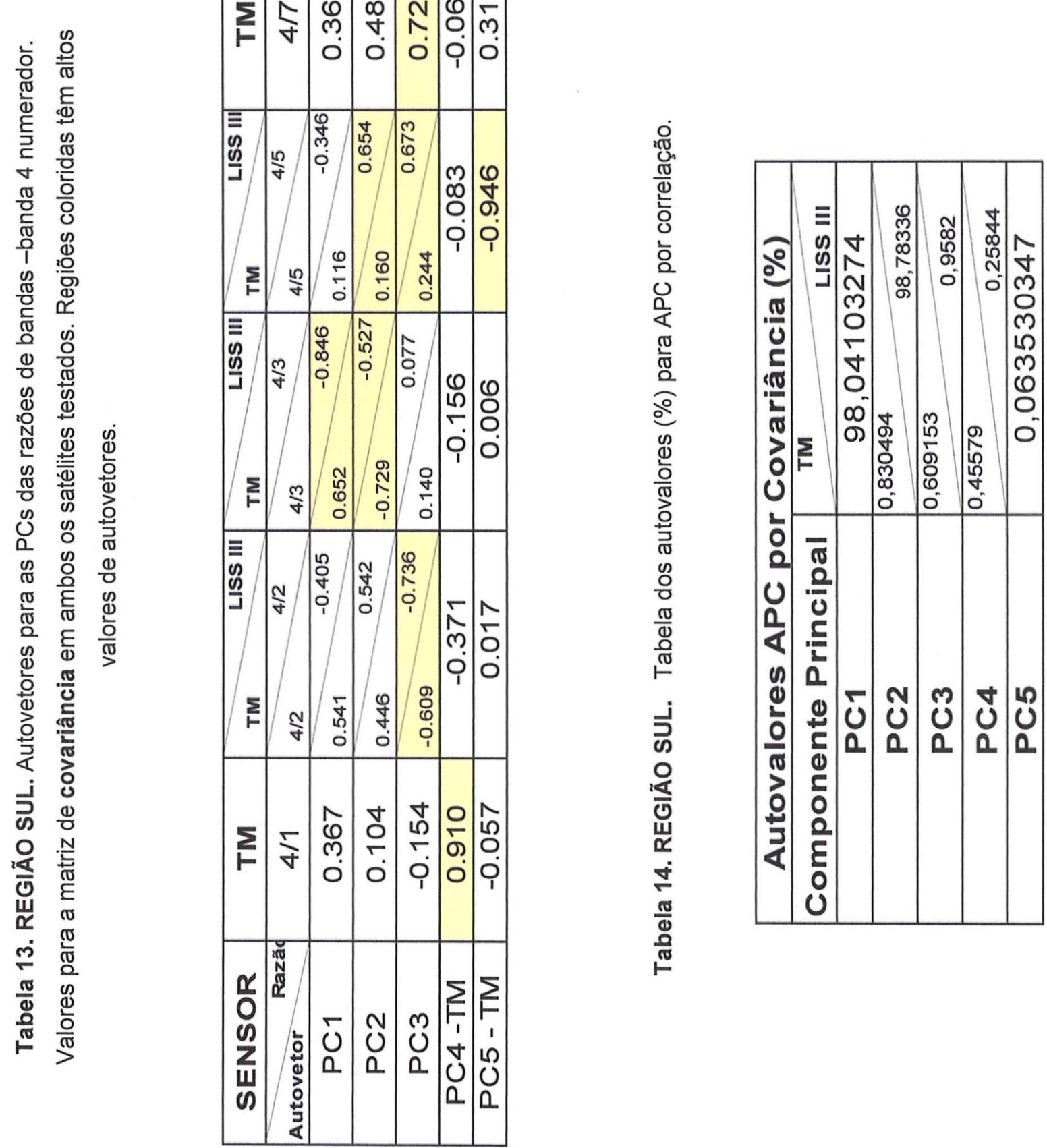
De maneira geral, os autovalores trazem informações sobre a segregação estatística realizada pela análise de componentes principais. A tendência geral é de decréscimo dos autovalores da PC1 para as PCs mais distantes. Isto ocorre justamente pelo acúmulo da informação redundante nas primeiras principais componentes (ver seção 6.3.1.1 - análises multivariadas).

Em todos os casos, as PCs1 trazem consigo a maior parte da informação redundante entre as bandas analisadas, com porcentagens em todos os casos maiores do que $60 \%$. É por este motivo que se atribui à PC1 a individualização da informação textural da imagem (albedo). É nesta PC onde toda a informação redundante proveniente de reflexões não lambertianas da luz se acumula, formando, via de regra, uma imagem muito rica em relação às texturas.

Deve-se notar ainda que as imagens obtidas pelo sensor LISS III apresentam em todos os casos, uma forte congruência nos autovalores, tendo as PCs primárias (na tabela nomeada PC2 por comodidade), com valores sempre entre 98 e $99 \%$. O motivo da ocorrência deste fenômeno está na pouca variabilidade de suas bandas espectrais em comparação ao sensor TM. Apesar de ambos apresentarem bandas praticamente análogas, a ausência das bandas TM1(azul) e TM7 (infravermelho de ondas curtas) é responsável por uma menor variância dos números digitais entre bandas, conferindo ao sensor LISS III uma maior correlação entre estas bandas. Isto pode ser entendido também como uma menor capacidade de distinguir feições, ou seja, uma menor sensibilidade do sensor ótico.

A análise de principais componentes, neste caso, faz seu papel muito bem quanto à segregação da informação textural que 'mascara' as feições buscadas pela geobotânica. Apesar das PCs 2, 3, 4 e 5 muitas vezes não representarem nem 5\% da variabilidade total entre as bandas, esta pequena parcela de informação é muito útil já que é justamente nessa porção de informação que estão contidas as feições mais sutis, como a diferença florística entre dosséis florestais distintos.

Os autovetores, por sua vez, têm o papel de informar o quanto de cada razão de banda foi aproveitado por aquela PC. Tomemos a tabela 12 como exemplo. Nela estão contidos os autovetores obtidos para a APC realizada por covariância na área sul. Nota-se que a PC1 é a banda que informação de maneira mais homogênea entre todas as razões. Diz-se isso pois os valores de autovetores para quase todas 
as razões de bandas estão, salvo para a razão $4 / 5$, acima de 0,30 . Sua principal contribuinte, no entanto, é a razão $4 / 3$, o que era esperado, já que a maior reflectância da vegetação (banda 4) dividida pela banda de maior absorção por parte das plantas (banda 3, vermelha) resulta em um forte incremento de valores de números digitais, creditados, neste caso, à arquitetura do dossel florestal, compondo portanto, a maior parte da informação textural presente na PC1.

Após a análise das tabelas de autovalores e autovetores, foram realizadas, enfim, as composições coloridas em falsa-cor para as regiões norte, central e sul, para ambos os sensores. Os resultados finais podem ser observados nas figuras 23 a 28 , seguintes, acompanhados ao fim de imagens de aerogeofísica de contagem total e composição com o canal K-Th-U em RGB (Figuras 29 e 30). 


\section{Imagem LISS III Geobotânica - ÁREA SUL $4 / 5$ (R) 4/2 (G) 4/3 (B)}
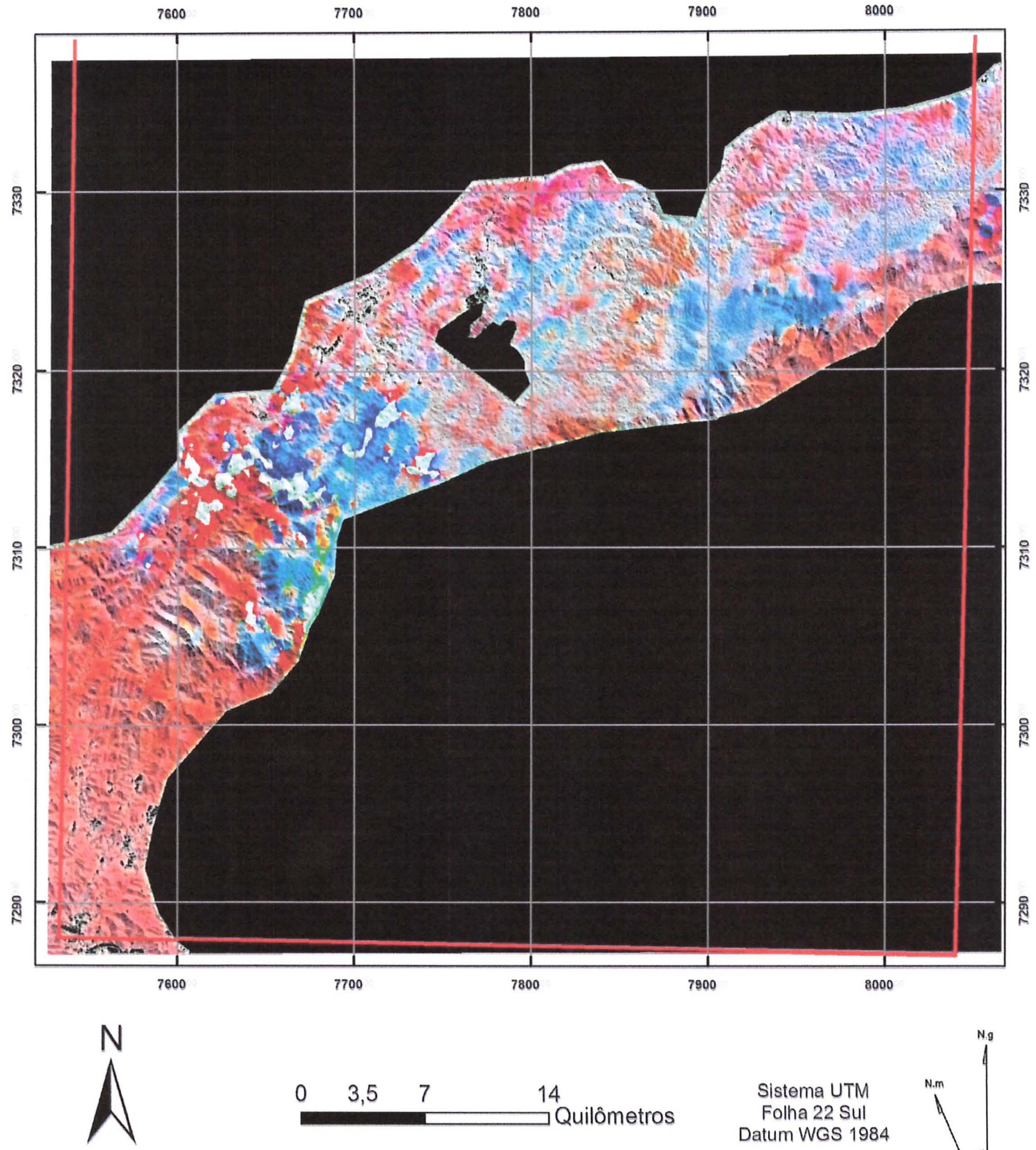

Sistema UTM

Folha 22 Sul

Datum WGS 1984

$1: 300.000$

Figura 23. 


\section{Imagem TM Geobotânica - FAIXA NORTE 4/2 (R) 4/5 (G) 4/7 (B)}
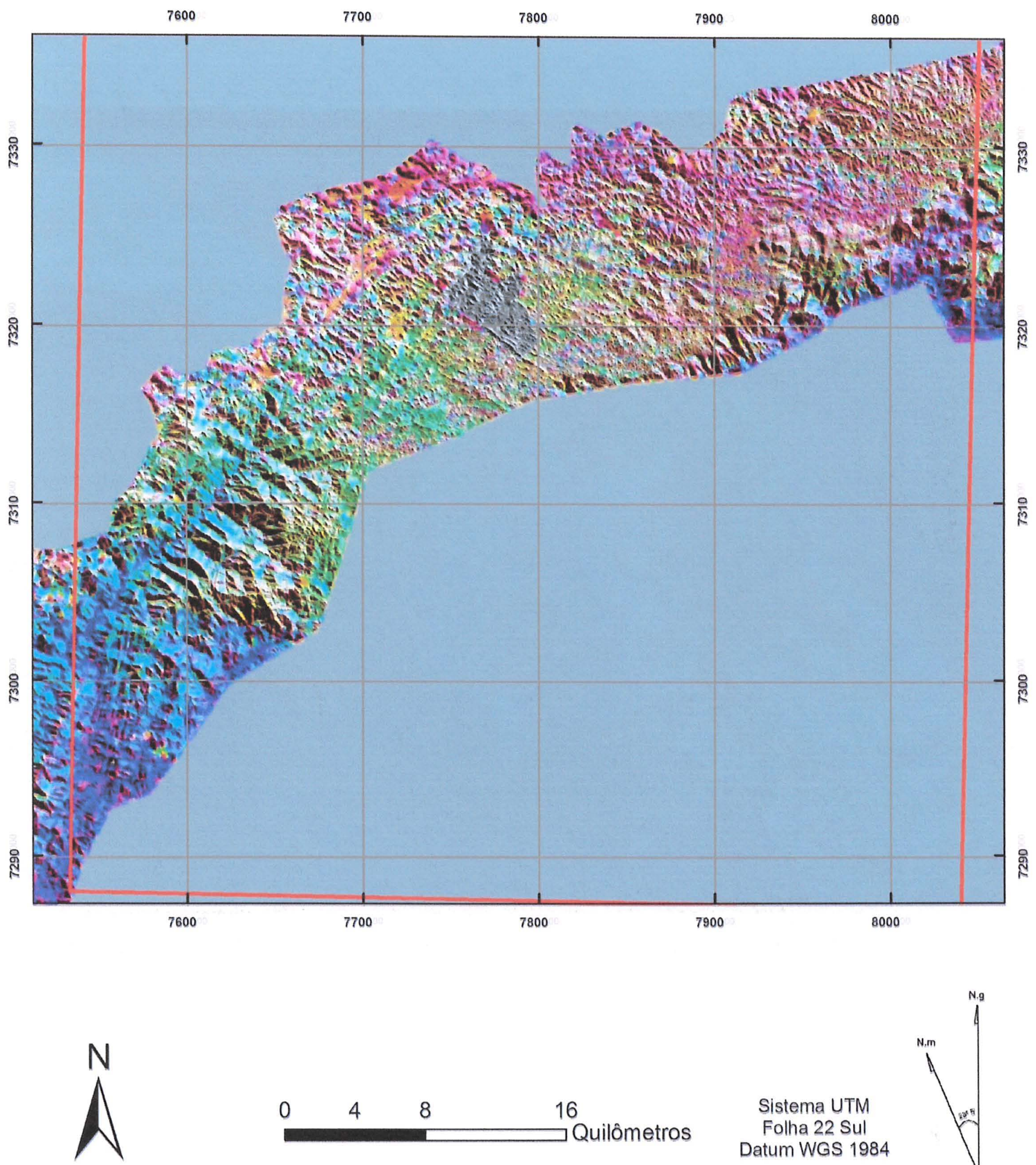

Sistema UTM

Folha 22 Sul

Datum WGS 1984 


\section{Imagem LISS III Geobotânica - ÁREA CENTRAL $4 / 3$ (R) $4 / 2$ (G) $4 / 5$ (B)}
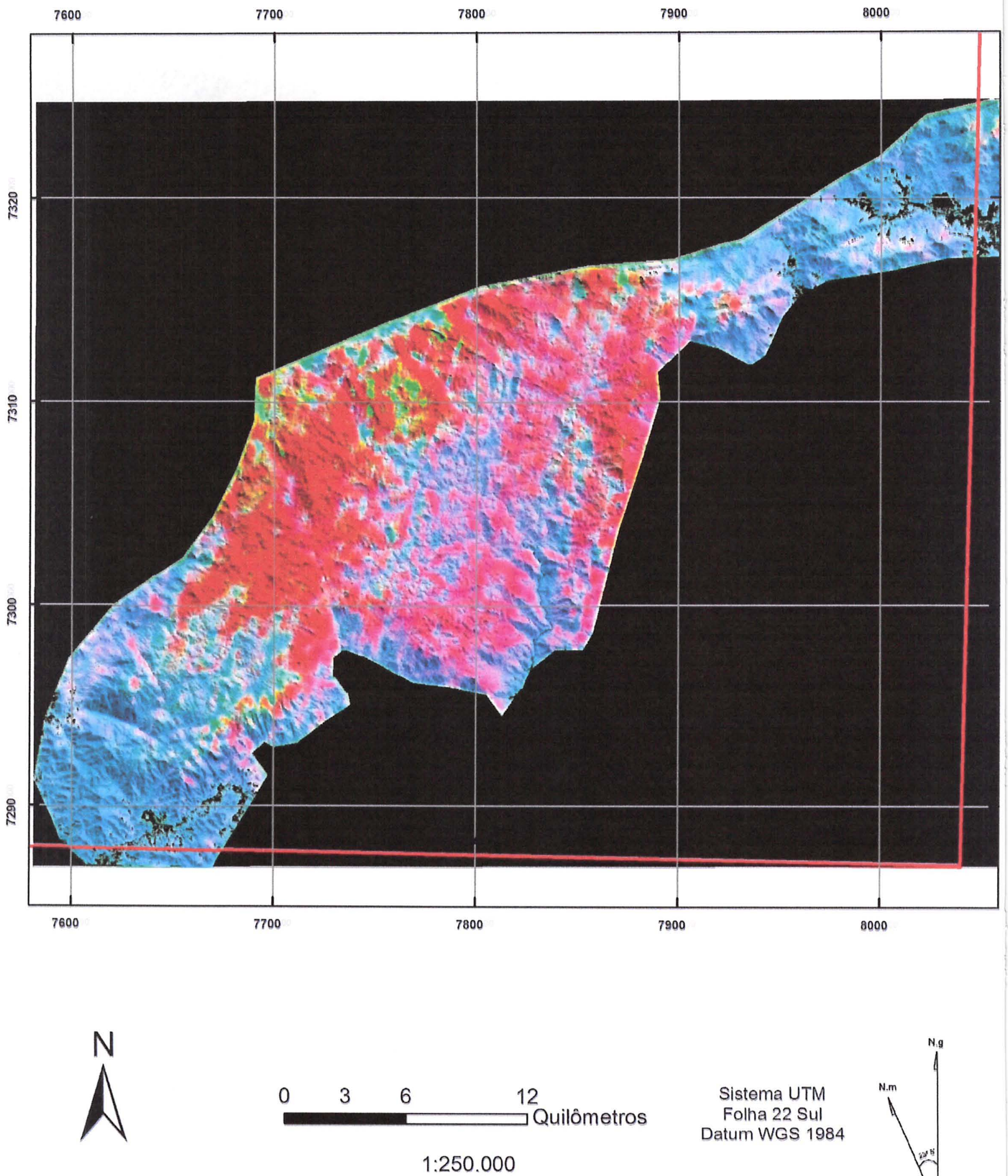

Sistema UTM

Folha 22 Sul

Datum WGS 1984

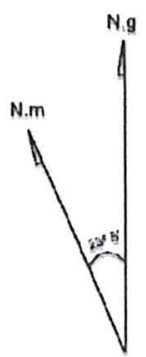

Figura 25. 


\section{Imagem TM Geobotânica - FAIXA CENTRAL 4/3 (R) 4/7 (G) 4/1 (B)}

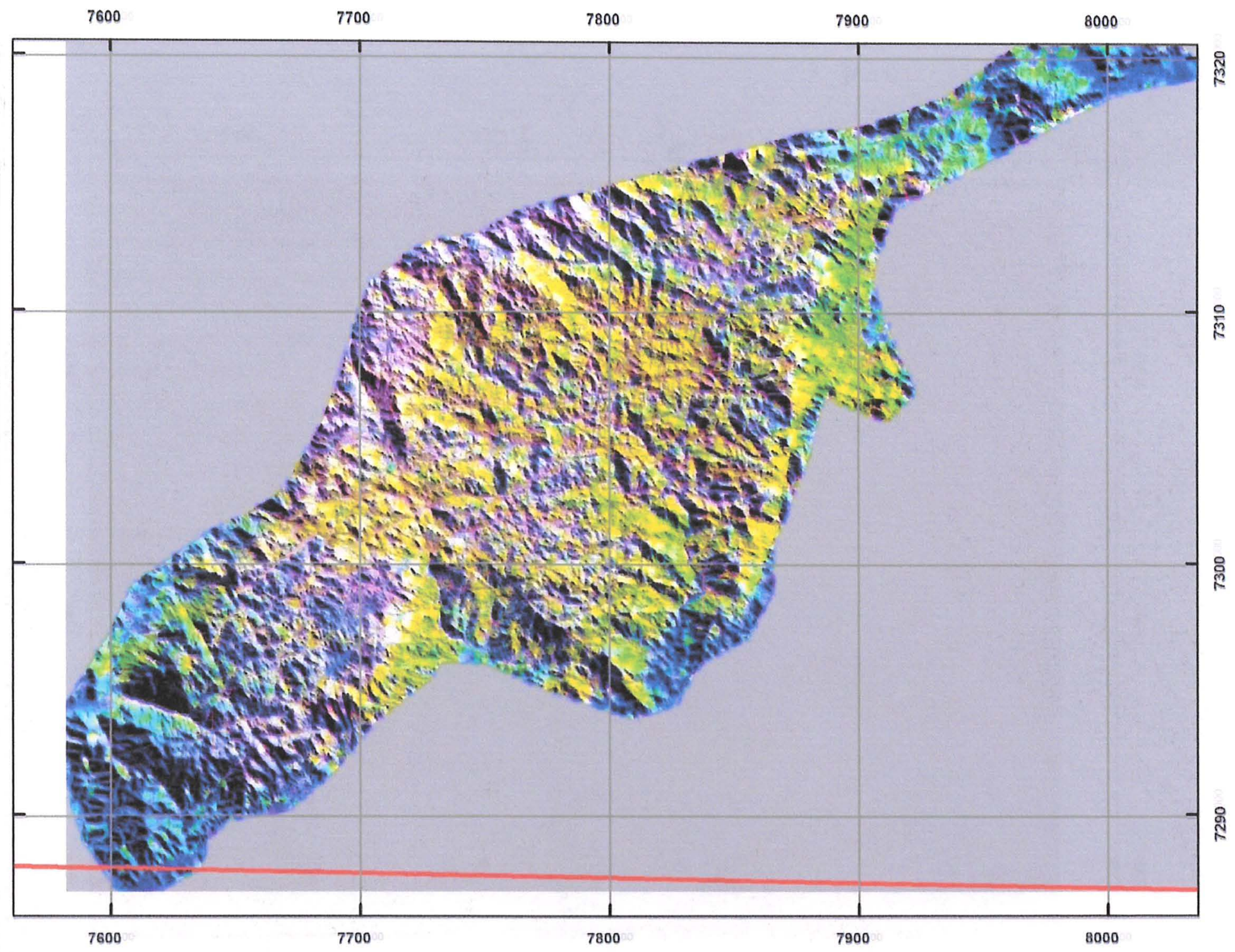

$\stackrel{N}{N}$

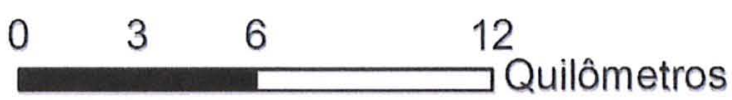

$1: 250.000$
Sistema UTM

Folha 22 Sul Datum WGS 1984 


\section{Imagem LISS III Geobotânica - ÁREA SUL $4 / 5$ (R) 4/2 (G) 4/3 (B)}
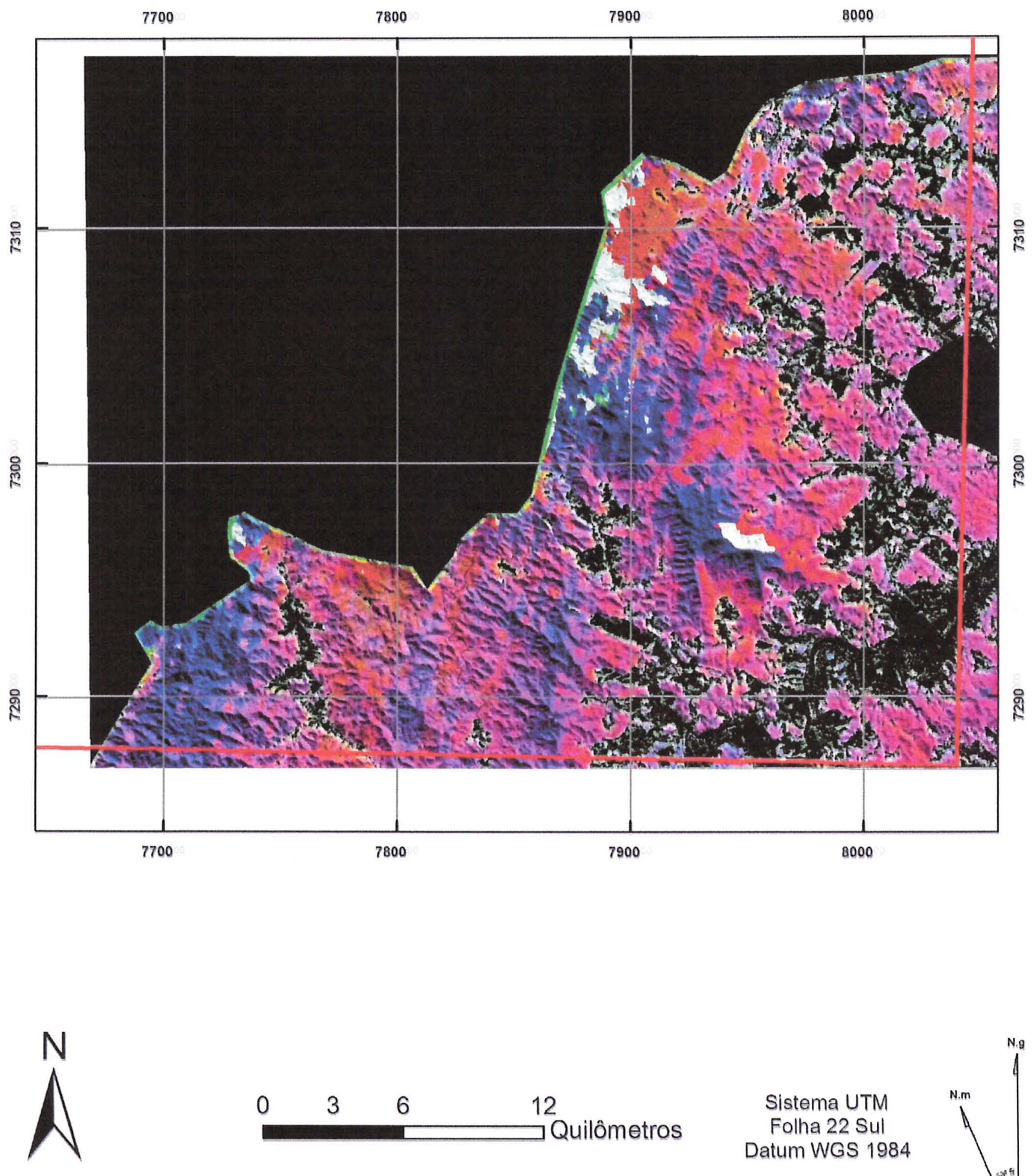

$1: 250.000$

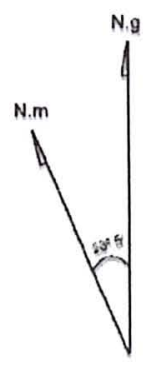

Figura 27. 


\section{Imagem TM Geobotânica - FAIXA SUL 4/3 (R) 4/5 (G) 4/7 (B)}
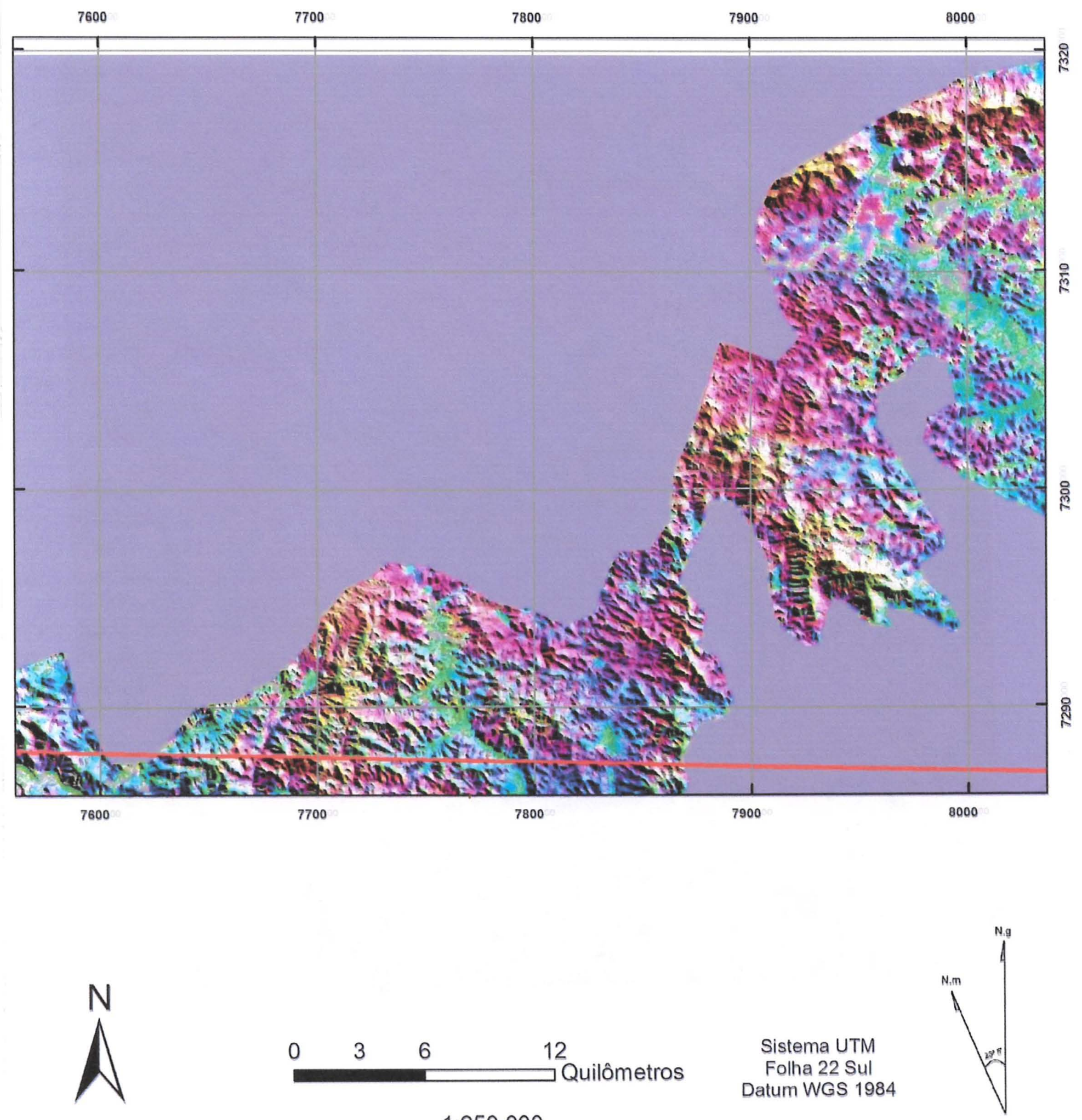

$1: 250.000$ 


\section{Aerogamaespectrometria de Contagem Total Levantamentos Aerogeofísicos Antigos (CPRM)}
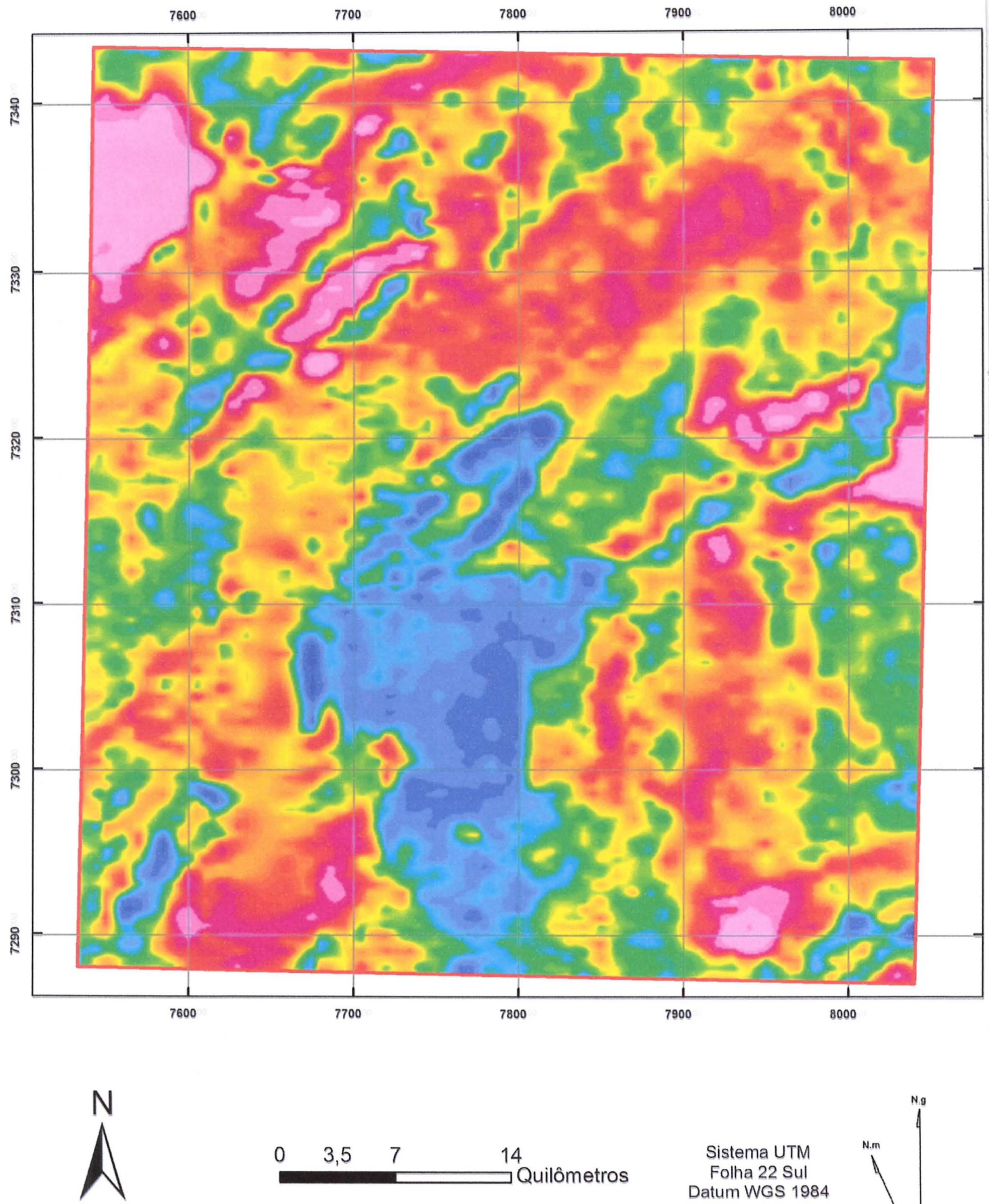

Folha 22 Sul 
Composição em Falsa Cor K(R) Th(G) U(B)

Levantamentos Aerogeofísicos Antigos (CPRM)
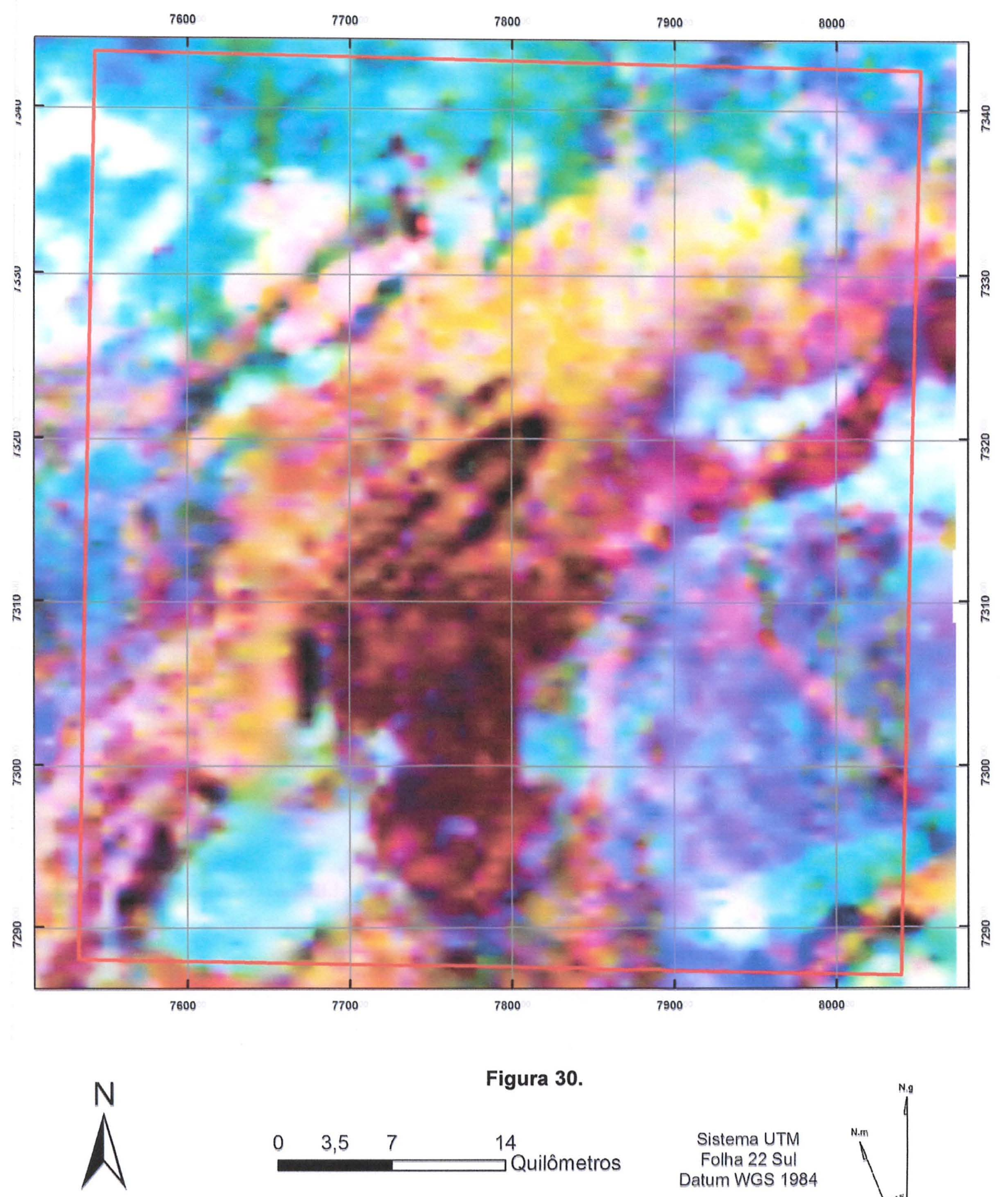

Figura 30.

14

Quilômetros

Sistema UTM

Folha 22 Sul

Datum WGS 1984

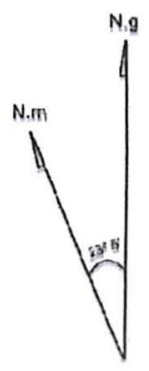


As figuras 23 a 28 mostradas nas páginas anteriores são o resultado final dos tratamentos em geobotânica realizados em duas imagens, provenientes dos satélites Landsat 5 e Resourcesat.

Como anteriormente citado, as imagens foram independentemente tratadas em faixas de ocorrências de diferentes grupos de rochas, a Faixa Norte, a Central e a Sul.

Para a comparação dos resultados com um método de sensoriamento remoto mais robusto, foram adicionadas as figuras 29 e 30 , que mostram dados aerogamaespectrométricos de toda a folha Capão Bonito. Estes levantamentos aerogeofísicos integram grande parte dos mapas geológicos da base 1:1.000.000 da CPRM, e foram gentilmente cedidos pela empresa.

É interessante observar a diferença de resultado obtida no tratamento dos diferentes produtos remotos. Apesar do satélite indiano Resourcesat ser muito parecido em sua concepção com o Landsat 5 , e de apresentar melhor resolução espacial (pixels de $22 \mathrm{~m}$ contra os quase 30 do Landsat), os resultados não parecem ser tão favoráveis neste satélite.

A não ser pela figura 27 , da área sul da folha, as outras duas imagens tratadas a partir de dados LISS III estão mais borradas. Suas variações de cor parecem aleatórias - podem existir nódoas e manchas com pouco significado real ou ainda podem apresentar padrões de alta frequência, associados a problemas na captura da imagem devido aos sensores de varredura tipo 'pushbroom', formando linhas paralelas como na figura 26 .

Outro problema enfrentado pelas imagens do sensor LISS III foi a ausência das bandas análogas às do sensor TM banda 1 (azul) e TM banda 7 (Infravermelho ondas curtas). A falta destas importantes fontes de informação espectral limitou muito o universo das análises estatísticas realizadas pelos processos de filtragem por principais componentes, gerando composições finais menos complexas e com menor grau de segregação de grupos florísticos. Este problema influi inclusive a percepção do relevo, o qual é adicionado ao final do tratamento como principal componente 1 da imagem original 
As diferenças entre os sensores podem ser vistas quando da comparação de quaisquer pares de imagens LISS III X TM. Em todos os casos é possível observar que ambos foram capazes de segregas as diferenças florísticas (e consequentemente do substrato) mais pronunciadas, mas o produto do sensor TM sempre é capaz de mostrar melhor as variações encontradas na área, através de cores mais variadas e com limites entre unidades mais bem marcados.

Para a área norte, ambos os satélites foram capazes de mostrar diferenças importantes entre a parte extremo oeste - onde predominam metassedimentos carbonáticos e pelíticos das Formações Água Clara e Betari - e a faixa de sedimentos que intercalam camadas pelíticas e arenosas da Formação Iporanga e do Grupo Votuverava. Na imagem Landsat, é possivel inclusive distinguir entre as camadas arenosas e pelíticas da região do anticlinal no centro da folha, em tons de verde e arroxeado.

Na região central da área de estudo (figuras 25 e 26) predominam os granitos do Batólito de Agudos Grandes. Esta região é interessante pelo fato de que apesar de se tratar de um corpo de granito único, tanto os dados da geobotânica, quanto as figuras 18 e 19 da aerogeofísica demonstram uma grande diferença do extremo oeste do corpo granítico em relação a sua parte leste, diferença esta nitidamente separada por uma estrutura NW-SE. A aerogeofísica demonstra que a porção a oeste da falha NW-SE é muito mais rica em Urânio do que a outra porção. A geobotânica confirma esta informação sugerindo a diferença química entre estes dois plútons da mesma unidade.

Por fim, a faixa sul apresenta uma boa correlação entre os resultados obtidos para ambos os sensores. A região é composta predominantemente de para e orto gnaisses miloníticos e anfibolitos do Complexo Embu, de algumas unidades metassedimentares clásticas neoproterozóicas do Açungui e das extensas planícies aluvionares da Depressão do Baixo Ribeira. Em especial esta última unidade pode ser muito bem distinta na figura 28 , em tons de ciano. 


\subsection{Modelagem Digital de Terreno}

A base de dados altimétricos utilizados para este trabalho foi o SRTM - Shuttle Radar Topography Mission. Estes dados foram obtidos a partir do Global Land Cover Facility, portal de distribuição de dados de sensores remotos da universidade de Maryland. São em formato matricial de 16 bits, podendo fornecer até 65.536 níveis de cinza, os quais correspondem à cota altimétrica pontual (pixel a pixel), com resolução espacial de 3 arcosegundos (90m). O principal motivo para a utilização desta base de dados é a facilidade de trabalho, já que o arquivo é disponibilizado em recortes análogos aos dos satélites da série Landsat, com tamanho de $185 \mathrm{~km} \mathrm{X}$ $185 \mathrm{~km}$, dispostos segundo o mesmo sistema órbita - ponto.

Além disso, foi considerado que, para a área de trabalho (uma folha 1:100.000 com cerca de $60 \mathrm{~km}^{2}$ ), a resolução destes dados seria satisfatória, evitando assim o fastidioso trabalho de digitalização de folhas topográficas manualmente.

A modelagem digital de terreno envolveu basicamente as seguintes etapas:

1 - Interpretação manual das estruturas da área através da geração de relevos sombreados com diferentes posições de azimutes solares.

2 - Elaboração de perfis altimétricos paralelos entre si, cortando as estruturas do embasamento perpendicularmente (direção NW-SE), com a finalidade de realizar um estudo pormenorizado do relevo da área, segregando superfícies de aplainamento, unidades de relevo e patamares relacionados a eventos erosivos.

3 - Aplicação do método das isobases para a interpretação das estruturas que apresentam controle na rede de drenagens.

Os resultados destas análises podem ser observados a seguir: 


\subsubsection{GERAÇÃO DE RELEVOS SOMBREADOS}

Os relevos sombreados podem ser conferidos na figura 31. Nesta ressaltamse principalmente as variações de sombra e luz provenientes da alternância dos azimutes solares utilizados $\left(0^{\circ}, 45^{\circ}, 90^{\circ}\right.$ e $\left.315^{\circ}\right)$, demonstrando como as diferentes direções de iluminação podem aumentar a capacidade de perceber nuances texturais e melhorar a interpretação fotogeológica. A partir destes produtos, foram obtidas mais de 300 estruturas, exportadas para um arquivo vetorial tipo shapefile (extensão .shp).

As estruturas interpretadas podem ser observadas na figura 32, dispostas sobre um modelo digital de elevação SRTM. As estruturas muitas vezes podem apresentar inflexões naturais, as quais foram desconsideradas para facilitar a geração da rosácea, por isso a maioria dos traços são retilíneos. No caso de inflexões bruscas das estruturas, optou-se por separar o lineamento em dois ou mais segmentos.

A criação deste shapefile permitiu gerar um diagrama em rosácea, que considera a frequência das direções das estruturas. Para a realização deste diagrama foi utilizado o Software livre OpenStereo (Grohmann \& Campanha, 200?). No diagrama (figura 33), a aba mais longa representa a maior contagem de indivíduos naquela direção. Para o caso deste estudo, há a predominância de estruturas de direção NW, reflexo do Alinhamento de Guapiara. Ocorrem, em segundo plano, estruturas NE, representantes da foliação metamórfica regional da faixa Ribeira. Estruturas N e E ocorrem subordinadamente, sendo interpretadas como inflexões locais na foliação regional, podendo estas serem concordantes com as fraturas $\mathrm{R}$ e R' de um sistema transpressivo-compressivo predominantemente dextral. 

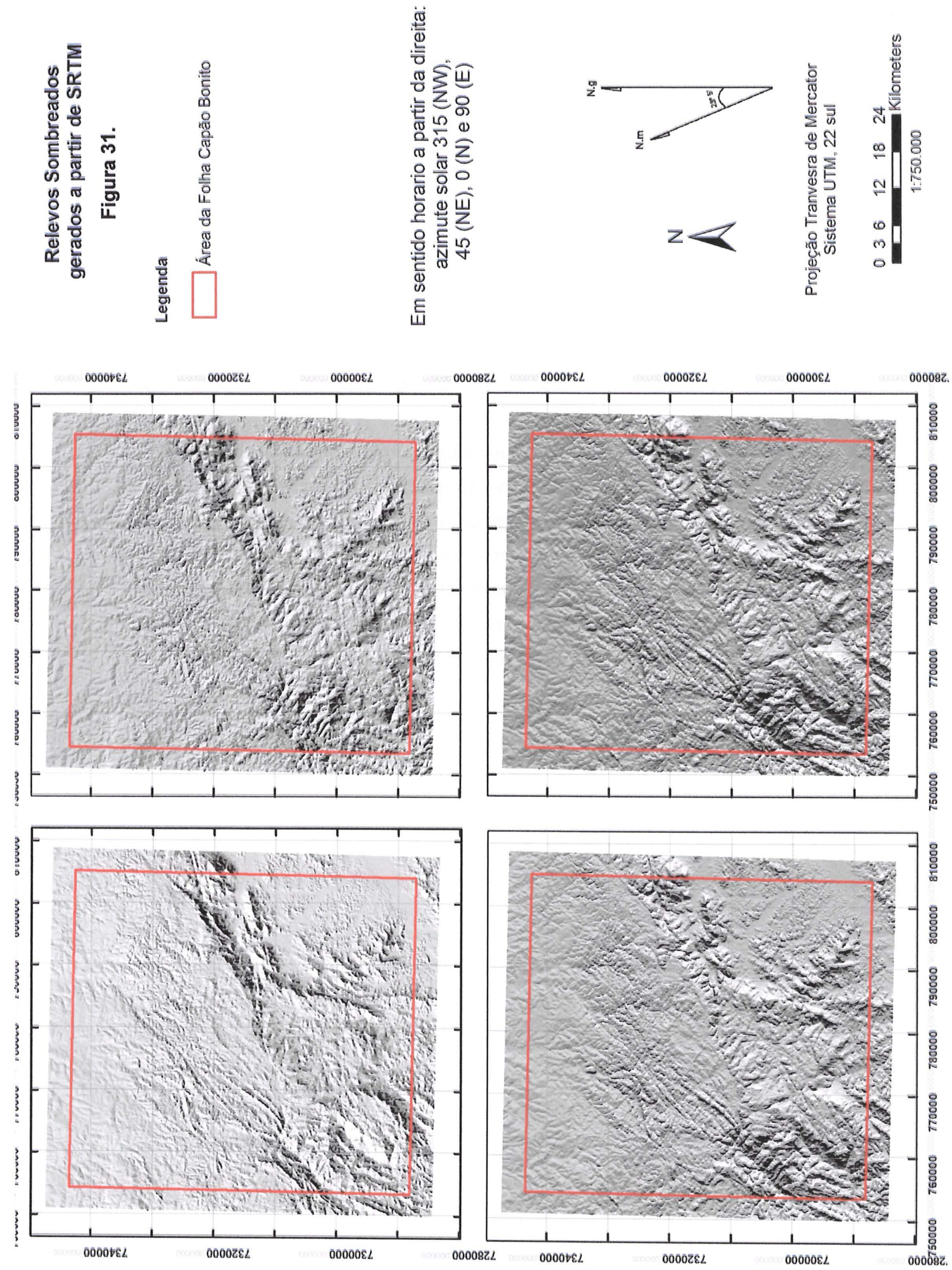

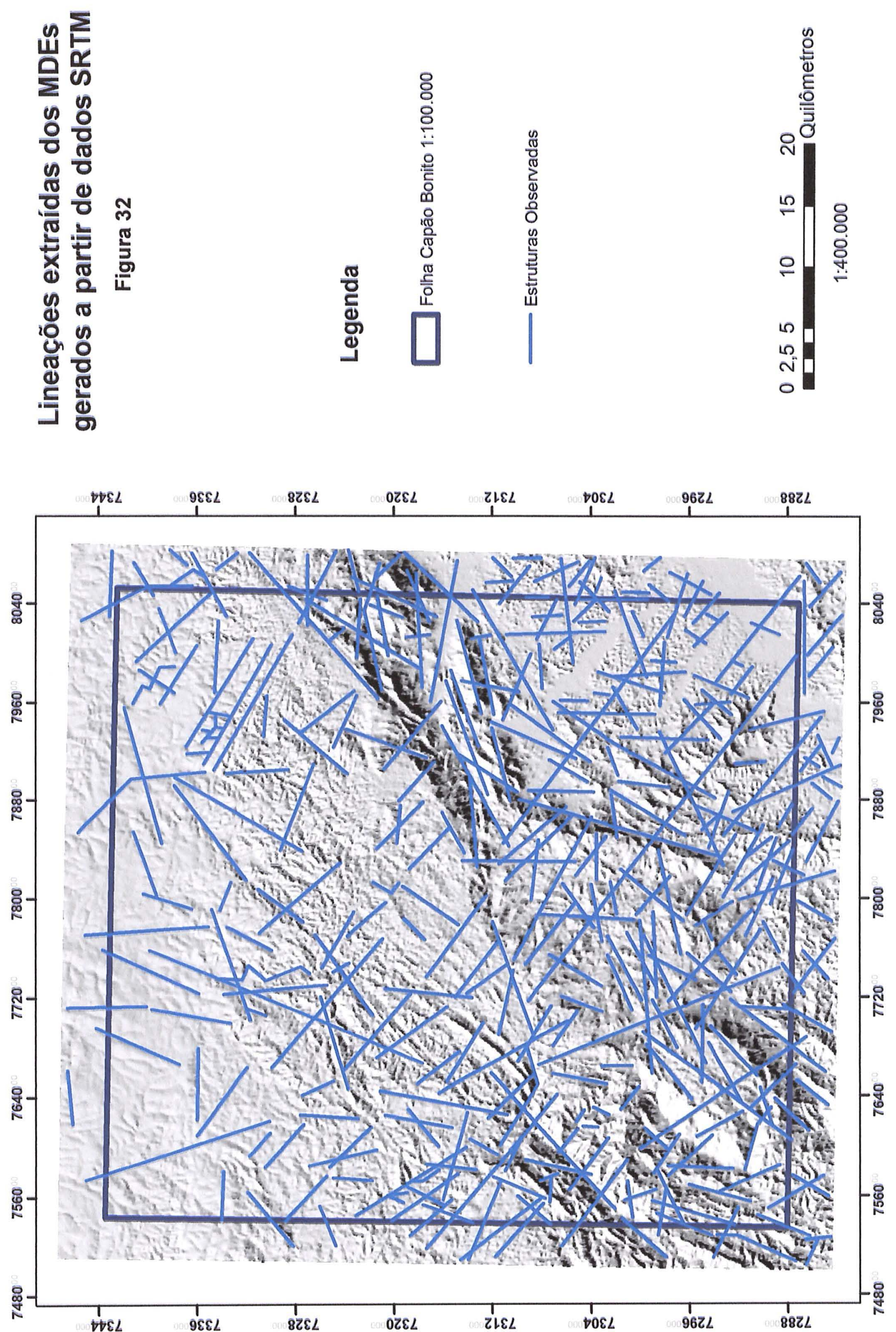


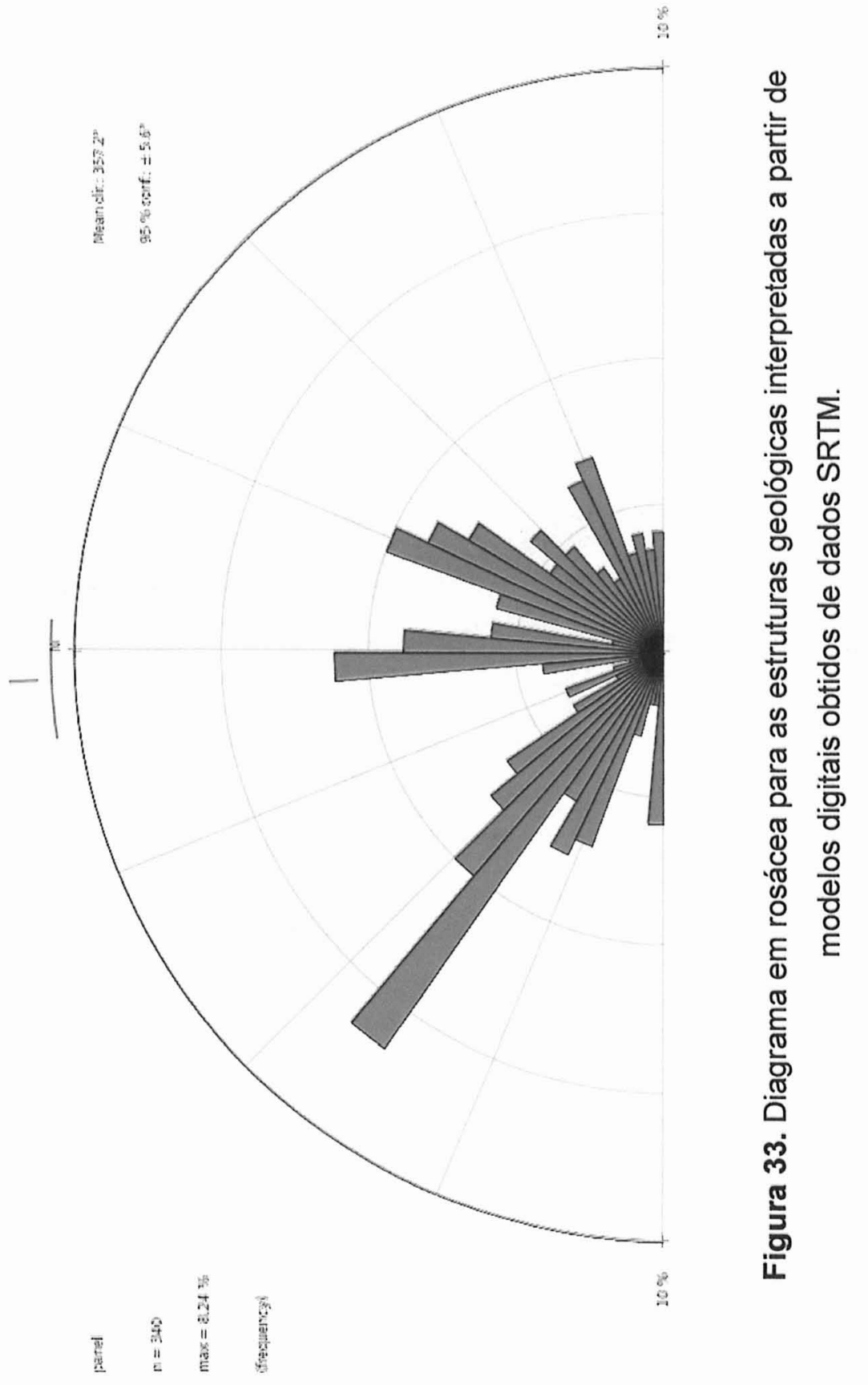




\subsubsection{COMPARAÇÃO DE PERFIS ALTIMÉTRICOS}

Este método se aplica ao estudo das variações regionais do relevo através da observação em seção da disposição de seus altos e baixos estruturais e de suas feições geomorfológicas - textura do terreno, estruturas geológicas etc.

Esta técnica é utilizada desde o início do século $\mathrm{XX}$, sendo reconhecida como uma técnica clássica de estudo geomorfológico, e pode ser feita manualmente. A ideia é traçar diversos perfis de altitude paralelos entre si (e preferencialmente perpendiculares às direções estruturais regionais), para então dispô-los em um mesmo plano cartesiano, para efeito de comparação.

Através da computação, o mesmo resultado pode ser obtido com a utilização de um modelo digital de elevação (no caso, o mesmo SRTM). Foram dispostos 7 perfis com espaçamento entre linhas de $2,5 \mathrm{~km}$ em direção NW-SE e outros 10 perfis espaçados em $500 \mathrm{~m}$ na porção SE do mapa, conforme a figura 34 .

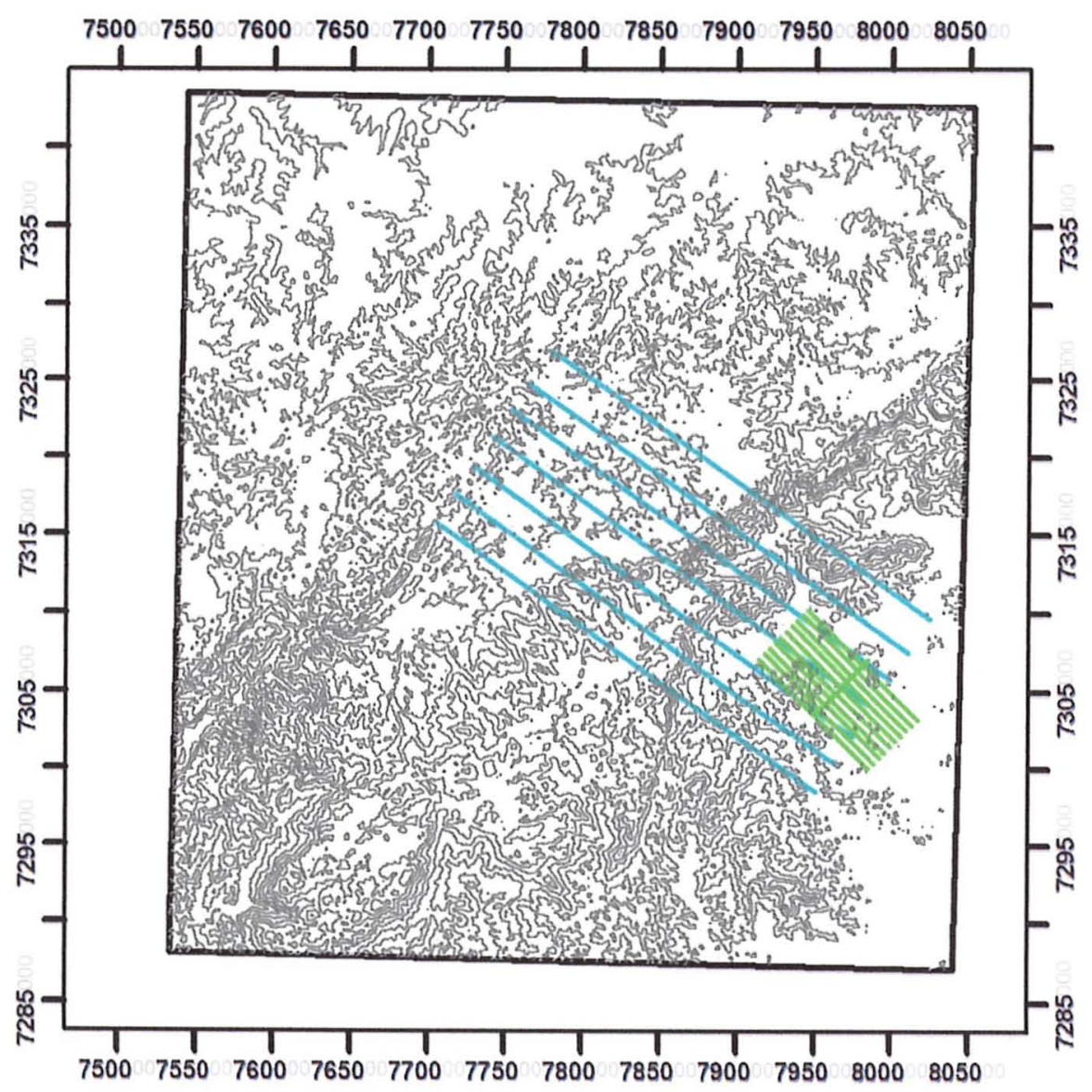

Figura 34. Localização dos perfis de altitude realizados na área. Em azul, perfis de $30 \mathrm{~km}$ de extensão espaçados em 2,5 km. Em verde, perfis de $10 \mathrm{~km}$ espaçados em $500 \mathrm{~m}$. 
Após a obtenção destes perfis altimétricos, todos foram colocados no mesmo plano cartesiano, para que pudessem ser comparados. $O$ resultado final foram dois gráficos de altitude $X$ distância contendo todos os perfis analisados, os quais podem ser observados na figura 35 .
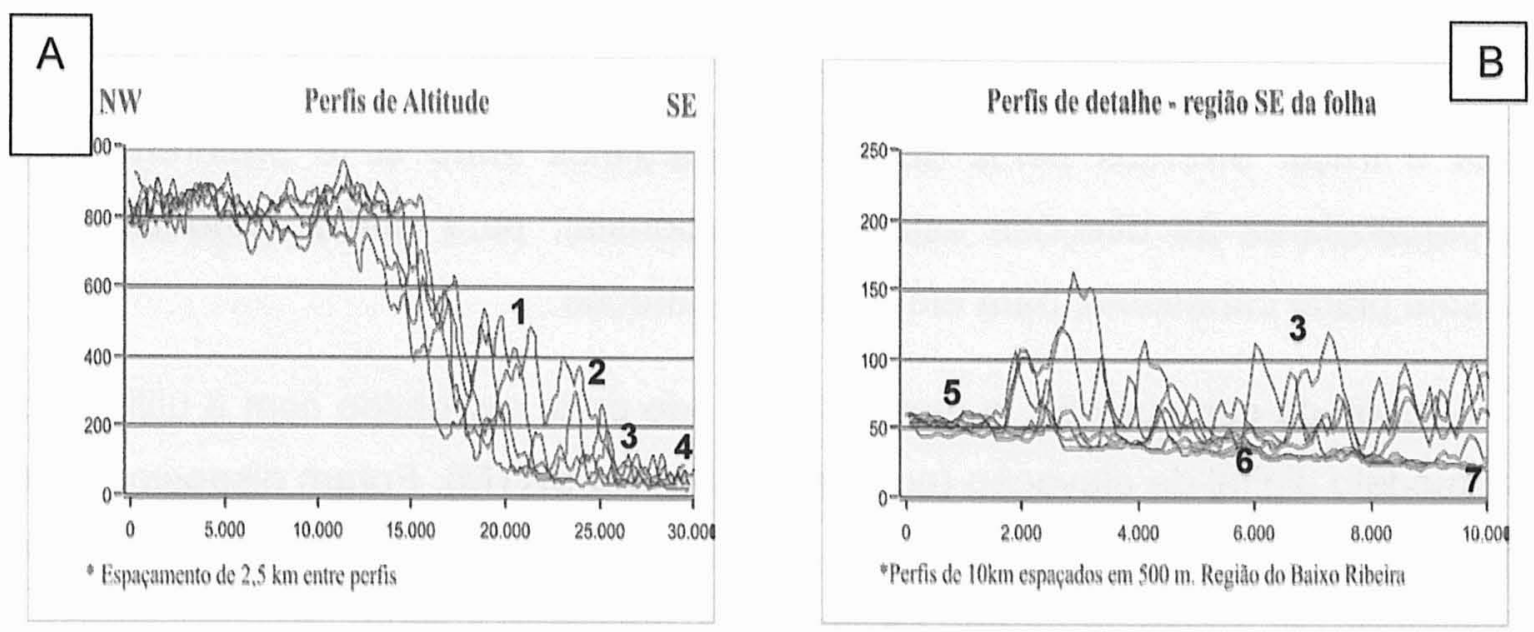

Figura 35. A. Notar o Planalto Atlântico (a NW) seguido da escarpa em patamares da Serra de Paranapiacaba. Mais a SE ocorrem 4 principais níveis. 1 - Por volta dos $450 \mathrm{~m}$. 2- Aproximadamente $350 \mathrm{~m}$. 3. Por volta de $100 \mathrm{~m}$. 4. Nivel de base atual $<50 \mathrm{~m}$. B. Perfis de detalhe da região do Baixo Ribeira. Observa-se o patamar dos $100 \mathrm{~m}$ (3), além dos prováveis paleo-niveis de base da bacia do Ribeira,: 50m (5), 35m (6) e <25m - nivel atual (7).

A interpretação destes dados demonstrou que a Serra de Paranapiacaba está escalonada em pelo menos três patamares na área de estudo. Na figura $24 \mathrm{~A}$, estes patamares são devidamente individualizados. São três alinhamentos de serras formando um relevo em dominó, o que sugere que estes 'degraus' tenham sido formados através do basculamento gravitacional dos blocos ao longo de estruturas NE-SW pretéritas (zonas de cisalhamento proterozóicas).

Uma análise na figura 24 B pode fornecer informações sobre o rebaixamento local ocorrido no Graben de Sete Barras. Nota-se que o relevo a SE é predominantemente plano, mas com ampla ocorrência de elevações entre $50 \mathrm{e}$ $100 \mathrm{~m}$. Estes morros são correspondentes ao patamar 3 e 5 , sendo facilmente identificados em campo ou em mapa como os morretes arredondados que se sobressaem às terras baixas da planície de inundação do Ribeira (ver geomorfologia, figuras 44 a 46) A região de drenagem atual (patamar 4, 6 e 7), se 
instalou muito provavelmente sobre a um último patamar muito rebaixado em relação às serras atuais que está situado abaixo do nível topográfico atual, configurando-se como embasamento para os sedimentos terciários do Graben de Sete Barras.

A técnica da comparação de perfis paralelos permite ainda perceber com maior clareza as compartimentações geomorfológicas regionais, como por exemplo, as terras planas do Plantalto Atlântico (a NW), a Serra do Paranapiacaba (centro) e a Depressão do Baixo Ribeira (SE). Mais detalhes sobre este trabalho podem ser observados no artigo de Kahwage \& Grohmann, 2013, publicado nos anais do XVI Simpósio de Sensoriamento Remoto e presente anexo a este trabalho (Anexo 04).

\subsection{3 - O MÉTODO DAS ISOBASES}

Conforme o discutido na parte de materiais e métodos deste trabalho (seção 6.2.3), o método das isobases é uma técnica que busca ressaltar a interação entre as drenagens de uma área e a geomorfologia. Este método gera um mapa de isovalores que traz informações inerentes ao controle estrutural das drenagens, reflexo de mudanças bruscas nos níveis de base locais pela atividade tectônica (falhamentos).

O resultado da aplicação desta técnica pode ser observado na figura 36 . Neste mapa, foram salientadas as estruturas que provavelmente detêm controle sobre as drenagens locais. Até a obtenção deste mapa final, foram realizados testes com diferentes configurações, levando em consideração os fatores que influem na geração das linhas de isovalores. Estes fatores são basicamente o tipo de interpolação utilizada e a distribuição dos pontos amostrados. Obviamente, a escolha da interpolação é opção do indivíduo que vai aplicar o método. A distribuição de pontos de intersecção entre drenagens e linhas de cota, por sua vez, é uma característica inerente ao meio ambiente, sendo impossível sua alteração. A única alternativa no caso de uma distribuição muito desigual de pontos é a reamostragem da área de estudo. Se esta reamostragem for uma diminuição da área estudada, muito provavelmente informações importantes do relevo podem ser perdidas e a amostragem acaba ficando restrita. A alternativa que sobra é o 
aumento da área de abrangência do método, resultando em um maior número de pontos cotados e, muito provavelmente, em uma melhor distribuição de valores.

Por causa deste entrave, a área da folha Capão Bonito foi expandida, e foi considerada toda a área observada na figura 36 . Além disso, vale a pena ressaltar que o método de interpolação escolhido foi o de spline, um método computacional que busca suavizar inflexões bruscas em valores. Este método ofereceu um resultado com linhas mais arredondadas, sendo considerado como uma interpolação mais condizente com as formas de relevo que ocorrem na natureza.
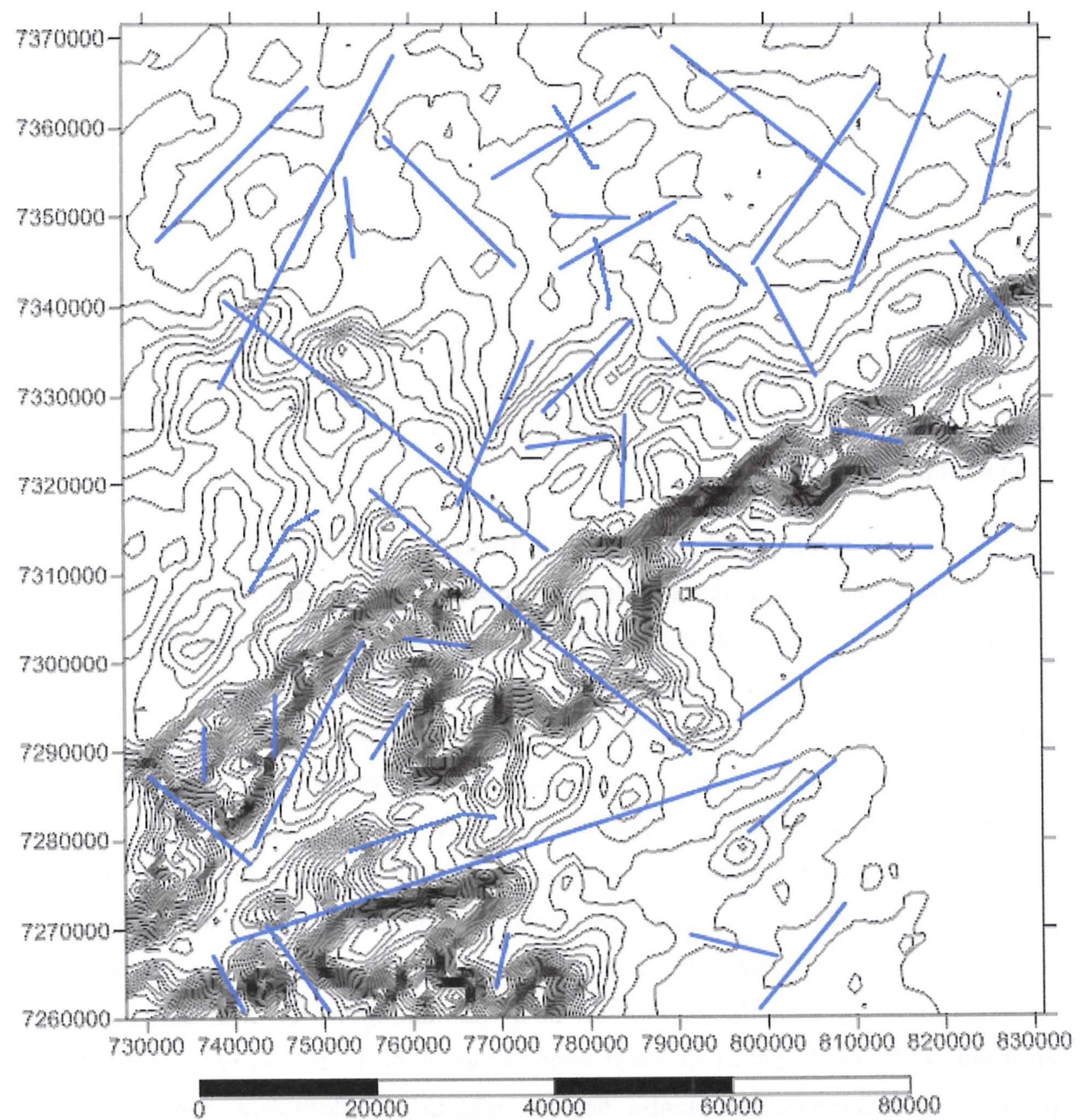

Figura 36. Resultado para o tratamento pelo método de isobases interpretado. Notar a expressividade das estruturas NW-SE e NE-SW, bem como a ocorrência de estururas N-S e E-W. Escala em metros. 
A interpretação do mapa das isobases é feita buscando encontrar as inflexões das linhas de isovalores. Estas variações bruscas são interpretadas como resultado da presença de um controle estrutural na rede de drenagens local. Apesar de parecer um conceito bastante subjetivo, o método das isobases é embasado na variação do nivel de base local.

Desta forma, entende-se que as variações de nivel de base são exacerbadas através deste método, mas cabe ao intérprete decidir se estas variações do comportamento das drenagens são de origem tectônica ou meramente erosivas.

Conforme observado na figura 36 , as feições demarcadas de maior extensão parecem estar relacionadas a estruturas NW-SE, direção de encaixe dos diversos diques de rocha básica alimentadores do magmatismo Serra Geral, à época da abertura do Oceano Atlântico. Esta feição, conhecida regionalmente como Alinhamento de Guapiara apresenta sem dúvida uma forte influência geomorfológica no controle da rede de drenagens. Como pôde ser observado em imagens aéreas, no entanto, sabe-se que estes diques podem servir tanto como estruturação para cristas elevadas, como de leito preferencial para a instalação de drenagens, formando vales.

As estruturas NE-SW, dominantes no contexto geológico da Faixa Ribeira, como o esperado, também se apresentam como controlantes das drenagens regionais. Apesar disto, suas extensões são menores, muito provavelmente pelo fato de que a foliação das rochas metamórficas acaba sendo um excelente plano de fraturamento, ainda mais quando apresenta altos mergulhos. Esta característica da estruturação das rochas aliada à alta pluviosidade da região fornece as condições ideais para o desenvolvimento de planos de escorregamento, úteis tanto para a infiltração de água e rápido avanço do intemperismo - geração de espessa cobertura de solos - como para desenvolver planos de falhas normais, quando da ocorrência de esforços tectônicos

Para tanto, é necessário que estruturas perpendiculares (NW-SE) ou concorrentes (N-S e E-W) interceptam a foliação gerando planos basculantes. Se observarmos novamente a figura 36 , vemos que estas estruturas estão presentes $\mathrm{e}$ são também responsáveis pelo controle das drenagens em uma escala menor. 
A análise da figura 36 permite ainda inferir que a disposição destas estruturas tem influência direta no formato da Serra de Paranapiacaba na região. Diz-se isto não só pela direção geral NE-SW da estrutura, mas pela presença de diversos avanços e recortes ao longo de sua escarpa principal. Com um olhar um pouco mais atento, observa-se que estes sulcos quilométricos estão dispostos principalmente segundo as direções NW-SE, N-S e menos pronunciadamente, E-W.

O método das isobases forneceu, portanto, uma visão geral e ampla da região em relação aos aspectos de dominância da rede de drenagem pelas diversas estruturas geológicas da área.

Considerando a complexidade geológica da região, foi importante sua aplicação para o destaque das estruturas NW-SE, NE-SW, N-S e E-W como sendo as principais controlantes da geomorfologia da região.

Este trabalho, vista a escala de trabalho (1:100.000), serve como um guia geral para a área, não sendo descartadas as variações locais que podem ocorrer na dominância das fraturas devido a fatores, tais como: proximidade a zonas de cisalhamento, proximidade a zonas de intenso fraturamento do alinhamento de Guapiara, entre outros.

A aplicação do método das Isobases reflete ainda a susceptibilidade de que estas estruturas mais proeminentes seja planos preferenciais de falhas e de movimentos menores como escorregamentos, o que pode servir de guia, inclusive, para um melhor planejamento do crescimento antrópico da região. 


\subsection{Interpretação de Fotos Aéreas}

Toda a área abrangida pelo estudo foi interpretada visualmente na escala 1:60.000, utilizando-se de acervo aerofotográfico gentilmente cedido pela CPRMSUREG-SP. As imagens foram encomendadas pelo Exército Brasileiro entre 1964 e1966 e estão disponíveis no anexo 4,CD, escanerizadas em uma resolução moderada e georreferenciadas em arquivo GEOTIFF. Estas aerofotografias foram georreferenciadas segundo bases cartográficas 1:50.00 (folhas Eldorado,Taquaral, Itacolomi e Aboboral) e posteriormente reprojetadas para o sistema de coordenadas UTM com datum WGS84 através do ArcGIS.

A interpretação de aerofotografias tem caído em desuso com a maior facilidade de acesso aos produtos de satélite de alta resolução. No entanto, isto não exclui a valia de uma interpretação, por assim dizer, 'mecanizada'. Dentre as vantagens encontradas na aplicação desta técnica ressaltam-se a escala das fotos aéreas, que é excelente para a interpretação geológica, além de que a estereoscopia mecânica é mais perfeita para gerar imagens em nossas retinas, tornando o efeito $3 \mathrm{D}$ muito mais nítido e perceptível quando comparado a um monitor de computador médio.

O intérprete aerofotogeológico alcança um detalhado resultado das estruturas da região, das texturas do terreno, das drenagens, da ocupação humana, enfim, da feição que estivesse buscando. Aqui, o enfoque foi a interpretação geomorfológica e neotectônica, conforme proposto pelo trabalho de Hiruma (1999). Nesta abordagem, buscam-se salientar na paisagem, elementos que sejam relacionados à atividade tectônica local - lineamentos, falhas, cristas, feições erosivas como voçorocas, rios com forte controle estrutural, entre outros.

O resultado deste trabalho foi a geração de um mapa de indicações morfotectônicas, e pode ser observado no anexo 2 .

Neste mapa, distinguem-se as regiões norte e centro-sul com facilidade. A norte aflora a borda dos sedimentos da Bacia do Paraná, onde ocorrem feições erosivas mais discretas, como depressões lobadas e voçorocas. Na porção NE da folha, cristas alongadas em direção NW e NE sugerem que as estruturas do embasamento 
têm continuidade para Norte e Oeste e que, muito provavelmente a espessura dos sedimentos paleozoicos na porção NE é menor.

$\mathrm{Na}$ região Norte do mapa, predominam colinas medianamente espaçadas, que formam rampas em suas faldas. Podem ocorrer ainda, morros testemunhos (figura 18) sustentados por rochas da Fm. Itararé. Estes sedimentos estão assentados diretamente por sobre o embasamento Neoproterozóico, o Grupo Açungui. Nesta porção, nota-se alguma influência dos lineamentos e estruturas do embasamento, principalmente na instalação de drenagens com direção NW na porção NE do mapa.

Na região metamórfica a sul, o padrão de drenagem é muito mais intrincado, com forte controle estrutural evidenciado por inflexões perpendiculares em cursos d'água nas direções NE-SW e NW-SE, mais raramente N. Ocorrem também, cristas alongadas conforme a orientação metamórfica regional, e grandes feições erosivas, principalmente grandes vales orientados NW-SE (na Serra de Paranapiacaba, a Leste) e escorregamentos (estes mais associados às direções dos planos de foliação NE-SW).

Nos planos de falha desenvolvidos ao longo desta foliação, formam-se as facetas triangulares ou trapezoidais. Estes planos são interpretados como sinais de atividade tectônica recente, conforme a figura 37. Na maioria das vezes, estas feições estão alinhadas segundo as direções principais NE e NW, podendo ocorrer em lineamentos E-W e N-S.

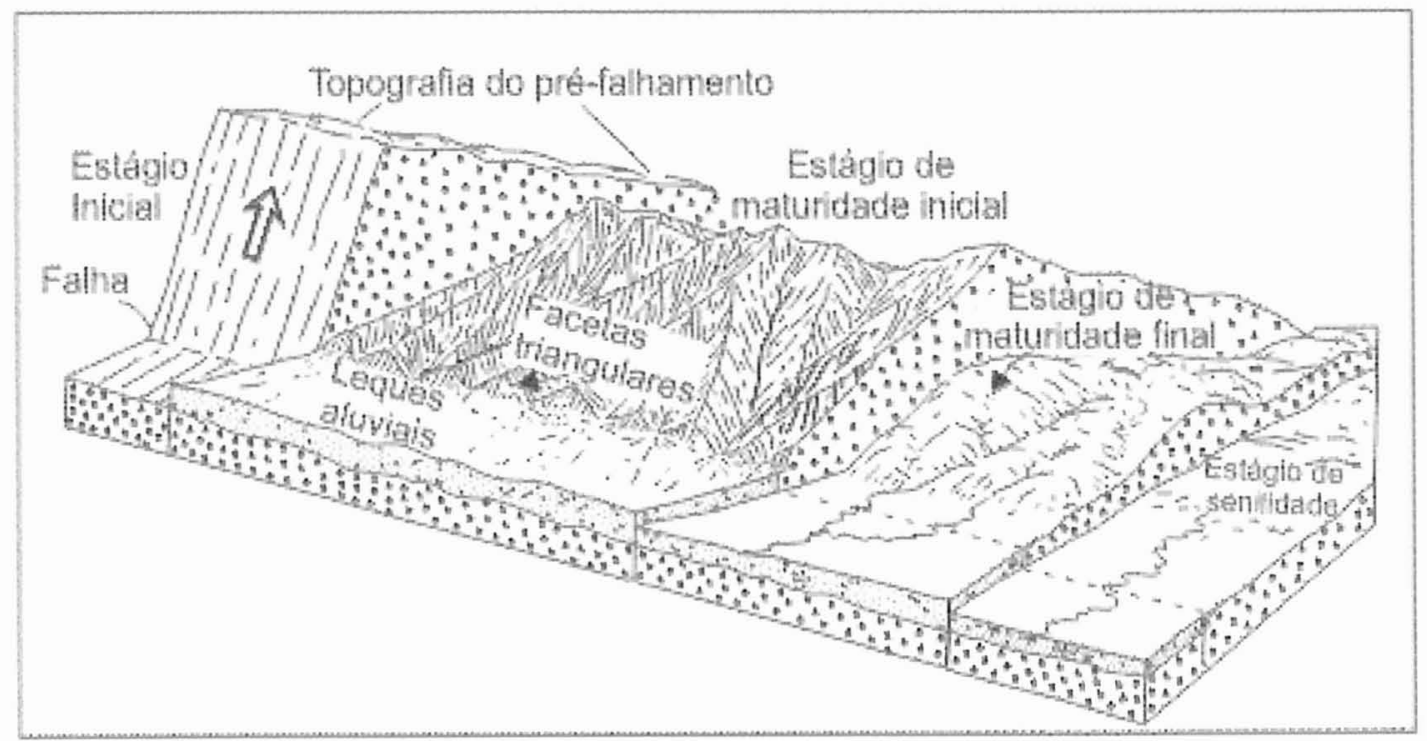

Figura 37. Esquema representando a evolução de uma escarpa de falha, em diferentes graus de maturidade do relevo. Strahler, 1971. 
As facetas trapezoidais e triangulares da região do Planalto Atlântico e Serra de Paranapiacaba são bastante comuns, mas não apresentam grandes extensões. Esta característica parece estar mais associada a uma gênese por parte de processos erosivos, creditando aos deslocamentos crustais um papel secundário. Tal fato não exclui a ocorrência de pequenos falhamentos e basculamentos de blocos, mas sugere apenas que, num contexto de clima quente e úmido e com a estabilidade crustal elevada dos últimos milhares de anos, os efeitos destes falhamentos possam ter sido muitas vezes encobertos pela ação da erosão. A própria Serra de Paranapiacaba é um testemunho de que a região é, ou até muito recentemente foi uma região de atividade tectônica importante, mas que agora apresenta uma fase de maior quiescência.

Mais a sul, após a escarpa da serra de Paranapiacaba, configura-se um domínio de relevo bastante diferente do observado nas áreas ao redor. Predominam nesta localidade colinas arredondadas que se sobressaem em uma ampla planície (figuras44 a 46). Estas colinas ocorrem em maior quantidade e altitude na região próxima à escarpa da serra, sendo gradativamente aplainadas conforme se caminha para SE, até o desaparecimento destas elevações para a instalação da atual planície de inundação do rio Ribeira de Iguape. Observa-se ainda que os morros em 'meia-laranja' apresentam um espaçamento bastante uniforme, configurando uma geometria quadriculada entre morros e pequenas planícies aluvionares, desenvolvidas nas direções perpendiculares NE-SW e NW-SE.

Esta geomorfologia sugere uma forte interação entre as estruturas proterozóicas do embasamento (NE-SW) e as estruturas jurássicas do Alinhamento de Guapiara (NW-SE). Configuram, portanto, mais um indício de que estas estruturas foram as responsáveis pelo rebaixamento do terreno na localidade (instalação do Graben de Sete Barras), bem como facilitaram a erosão fluvial, fornecendo aos cursos d'água que drenam a Serra de Paranapiacaba um leito para que escoassem e configurando um quadriculado de morros e planícies aluviais. $O$ grande índice de chuvas orográficas na localidade contribuiu ainda para um rápido entulhamento da depressão do Graben de Sete Barras, bem como uma acelerada evolução da paisagem da planície do Ribeira. 


\section{4- Levantamentos de Campo}

Foram realizadas duas etapas de campo, a primeira no final do ano de 2011, durante os dias 08 de novembro até o dia 15 de novembro. A segunda etapa foi realizada durante os dias 14 a 18 de maio de 2012. Ambas as etapas contaram com a participação e apoio da equipe de mapeamento da CPRM - Superintendência de $\mathrm{SP}$, da qual participam os geólogos Frederico Meira Faleiros, Maurício Pavan e Carlos Libório Tomba.

Foram cadastrados durante estas duas etapas, cerca de 200 pontos de afloramentos (figura 38). Durante a primeira etapa, os caminhamentos se concentraram na porção NW e extremo SE da folha. A segunda etapa contemplou o detalhamento da porção NE da folha, bem como mais um caminhamento na porção SE.

A ausência de pontos na porção central da Folha Capão Bonito se deu por dificuldades administrativas encontradas ao longo do trabalho, tal como o fato de que o local é considerado uma APP (Área de Proteção Permanente) do Continuum Ecológico de Paranapiacaba e, para lá serem realizados trabalhos de amostragem e de caminhamento, era necessária autorização e apoio dos órgãos gestores dos parques. Houve grande morosidade para a liberação e a disponibilização dos arquivos vetoriais das trilhas e picadas que existem na mata. Neste ínterim, a CPRM acabou por colocar o projeto de mapeamento da Folha Capão Bonito em segundo plano, priorizando regiões desconhecidas do Mato Grosso do Sul. Assim sendo, ficou suspensa a terceira etapa de campanha que complementaria o estudo aqui demonstrado.

Os caminhamentos realizados possibilitaram a descrição de grande variedade litológica, principalmente de rochas pertencentes ao Grupo Votuverava, aflorantes a norte do Batólito de Agudos Grandes. Este agrupamento de rochas é composto por uma sequencia metassedimentar de caráter predominante siliciclástico, com raras ocorrências de rochas vulcânicas intercaladas, além de carbonatos.

Além do trabalho de levantamento litológico, foi dada atenção especial à geomorfologia da área estudada, sendo realizados registros fotográficos das principais feições ocorrentes. Esta será a primeira seção descritiva da parte de levantamentos de campo, a seguir. 


\section{Fig.38 Mapa de Pontos Cadastrados}

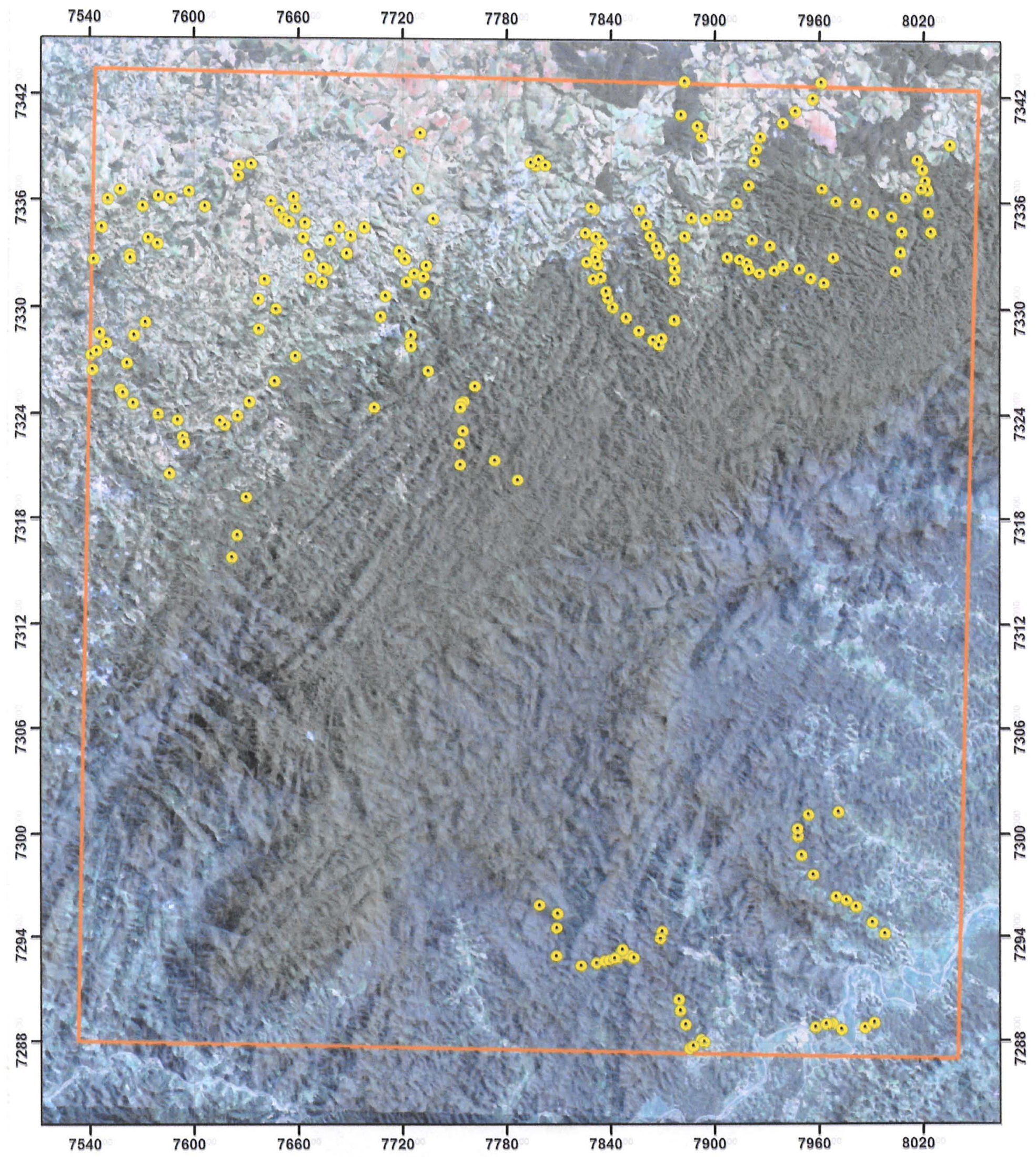

Imagem de Satélite LANDSAT5 em composição 321 (RBG)

órbita -ponto 220/77 de 23/05 de 1991

sobre relevo sombreado obtido a partir de dadoS SRTM

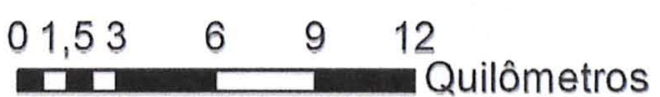

\section{Legenda}

- Pontos de Caminhamento Área da Folha Capão Bonito 


\subsubsection{GEOMORFOLOGIA}

A geomorfologia da área da folha Capão Bonito é bastante diversa, sendo dividida conforme o apresentado na seção de geomorfologia da revisão bibliográfica (páginas 25-28). Ocorrem na folha pelo menos três grandes domínios geomorfológicos, sendo, de norte para sul a Depressão Periférica da Bacia do Paraná, o Planalto Atlântico, e a Depressão do Baixo Ribeira.

Uma visão geral da geomorfologia da área pode ser tomada na Figura 39, a qual traz uma modelagem digital de elevação gerada a partir dos dados SRTM em conjunto com uma imagem LANDSAT. Esta imagem é uma composição das bandas 321 distribuídas no canal RGB, sendo equivalente ao colorido real.

O bloco-diagrama representa a região da folha Capão Bonito, com visada para SE. Nele, notam-se diversos picos agudos, que não parecem feições muito naturais. Esta distorção na representação do terreno ocorre por dois motivos, sendo um a maneira como são adquiridos os dados, e o outro, pelo tratamento dado. O primeiro é que as informações numéricas da altitude são pontuais (pixels do SRTM de $90 \times 90 \mathrm{~m}$ ), o que, muitas vezes resulta em diferenças de altitude bruscas entre pixels computacionalmente próximos. No terreno, 90 metros fazem

Figura 39. Modelo Digital de Elevação da Folha Capão Bonito. Notar a parte com maior ocupação humana - planícies da Bacia do Paraná e borda do Planalto Atlântico. Região mais montanhosa central - Planalto Atlântico. Zona Rebaixada à esquerda - Depressão do Baixo Ribeira.

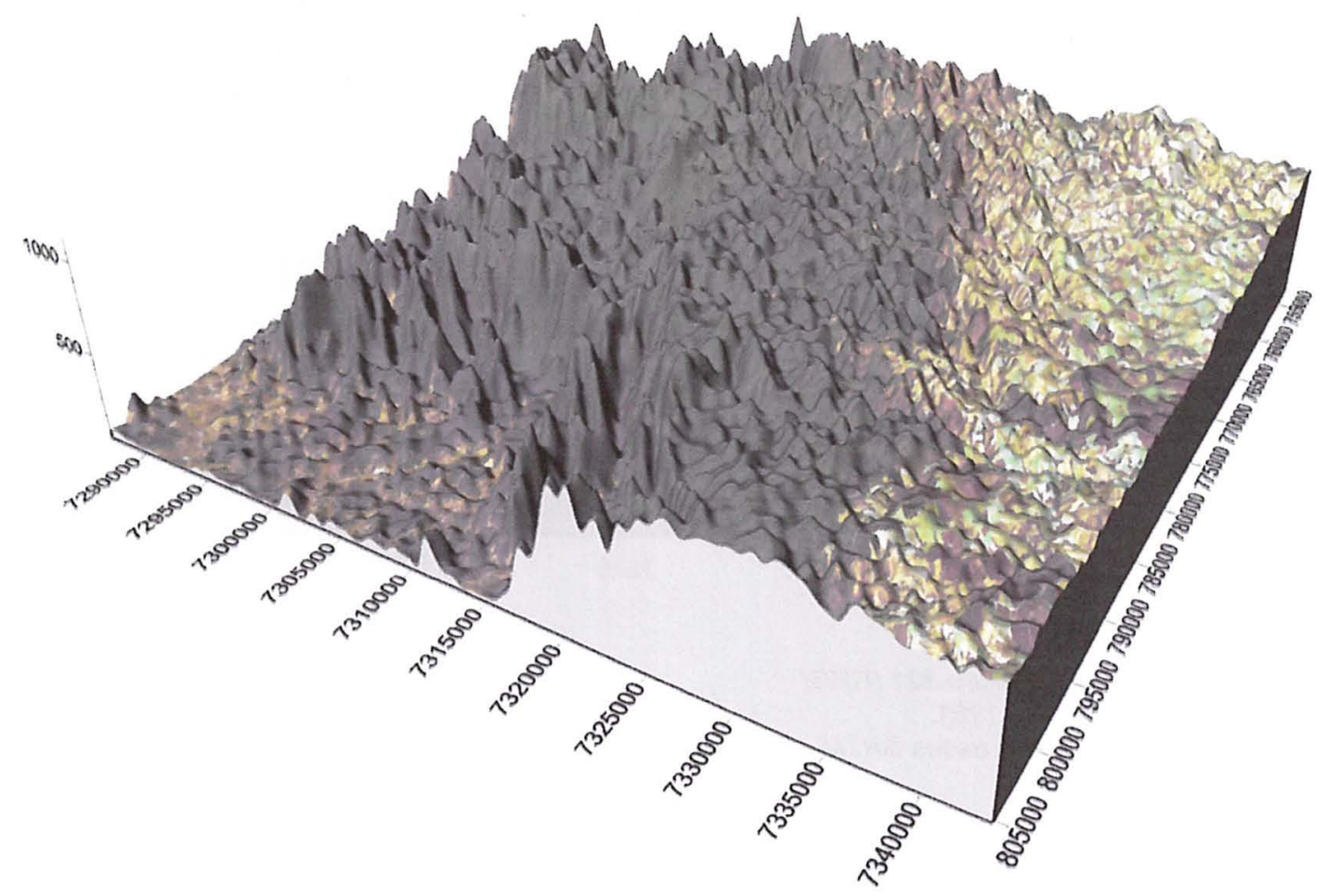


bastante diferença em uma região de relevo rejuvenescido como na Serra de Paranapiacaba. Em segundo lugar, a diminuta escala horizontal utilizada frente ao exagero vertical, gera uma compressão lateral do espaço das bases do morro, alterando seu formato para algo mais afilado do que realmente é.

A região onde se situa a cidade de Capão Bonito - extremo NE da folha - está na divisa entre o domínio da Bacia do Paraná e o embasamento metamórfico que domina o Planalto Atlântico. Na figura 40, pode-se observar uma tomada da paisagem da região rural de Capão Bonito a sul da cidade, com visada para NE. Nesta foro observa-se em primeiro plano, as serranias e morros mais pronunciados do Planalto Atlântico, e, bem ao fundo do lado direito, extensas planícies - já no domínio da Bacia do Paraná.

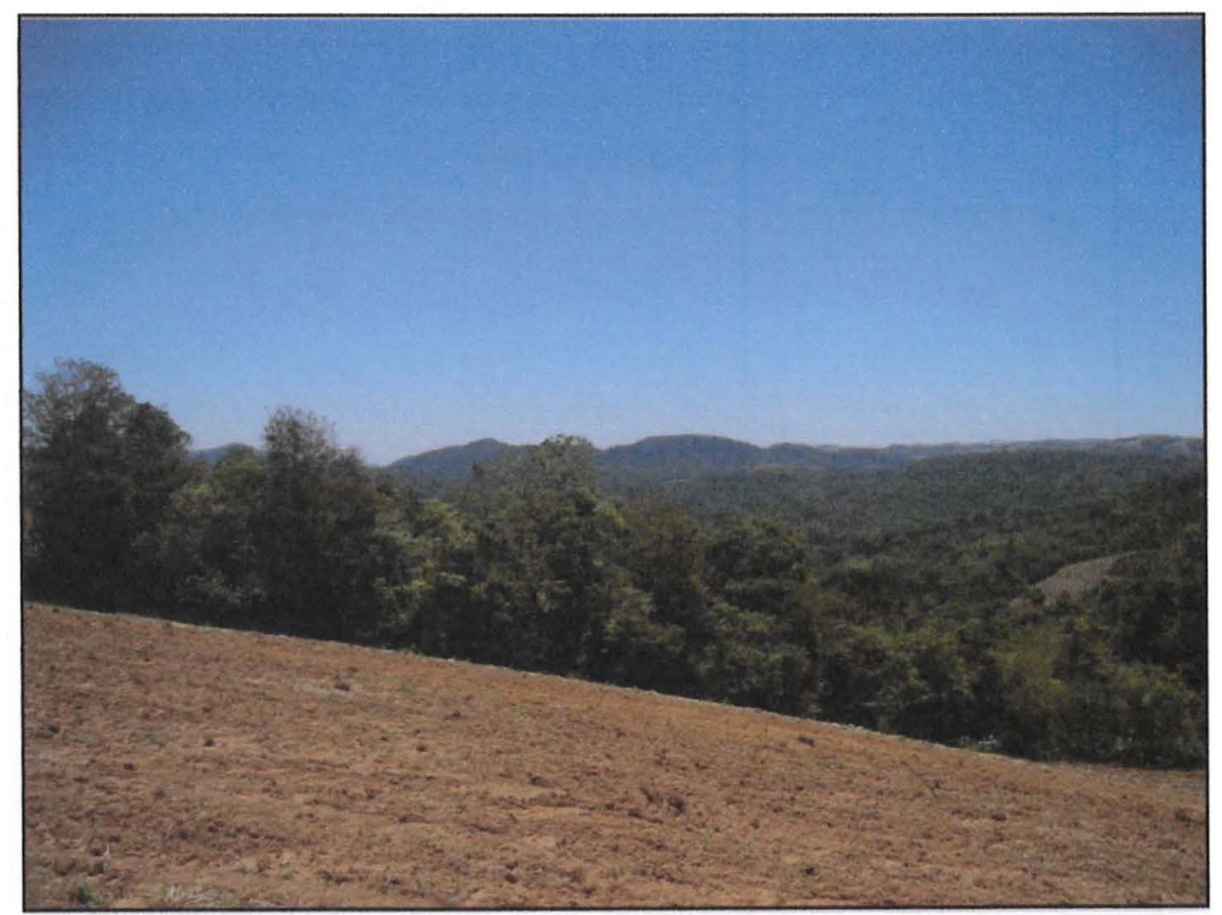

Figura 40. Geomorfologia da faixa norte. Morros pronunciados em primeiro plano no contexto do Planalto Atlântico. Ao fundo, a direita - planícies da Bacia do Paraná.

Conforme se caminha em direção a sul, passam a predominar os relevos mais acidentados, com vales incisos em $V$, em direção à escarpa principal da Serra de Paranapiacaba (figura 41). Na região da borda, no entanto, podem ser preservados morros testemunhos da sedimentação paleozoica, conforme observado na figura 42. 


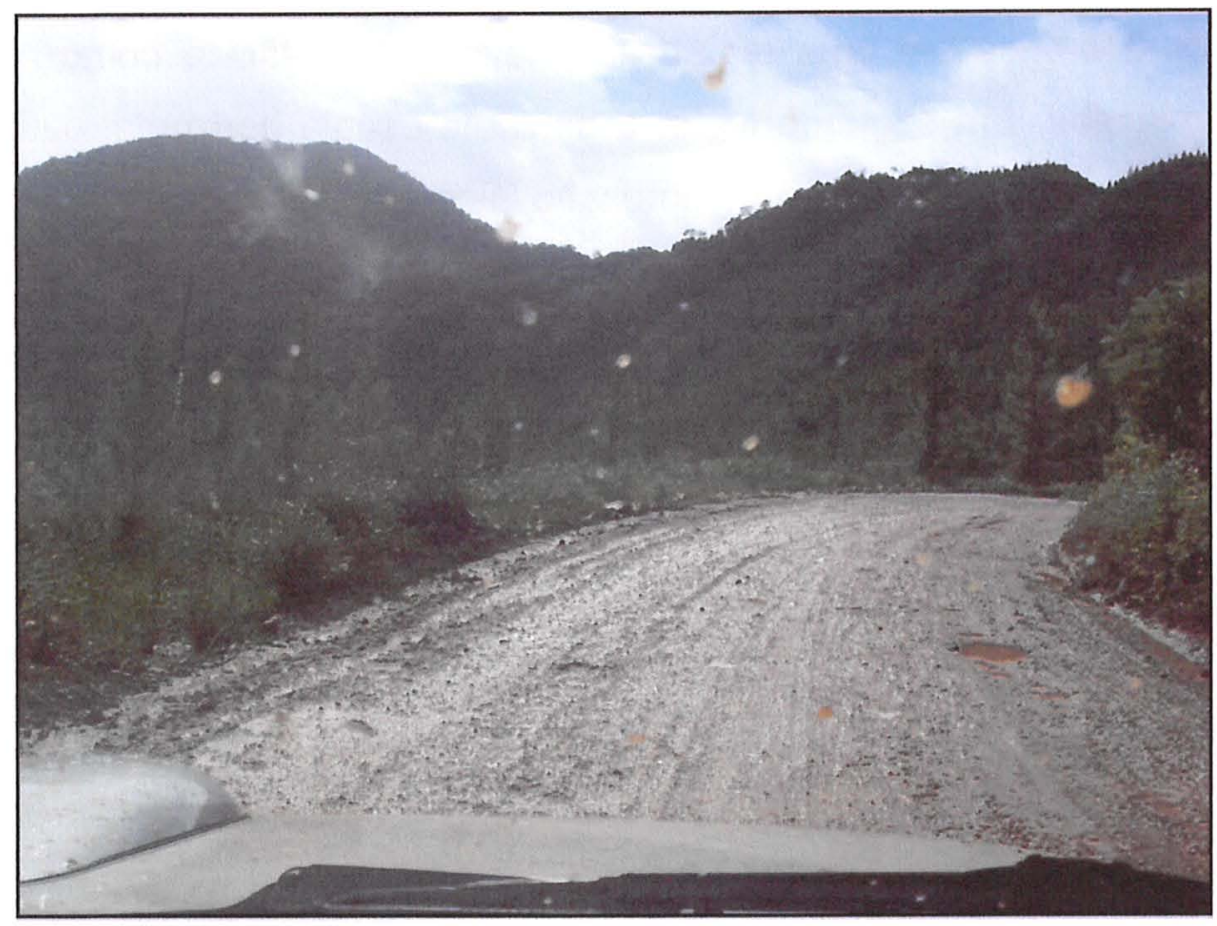

Figura 41. Geomorfologia da faixa norte. Morrarias com vales profundos, Planalto Atlântico. Centro da Folha Capão Bonito.

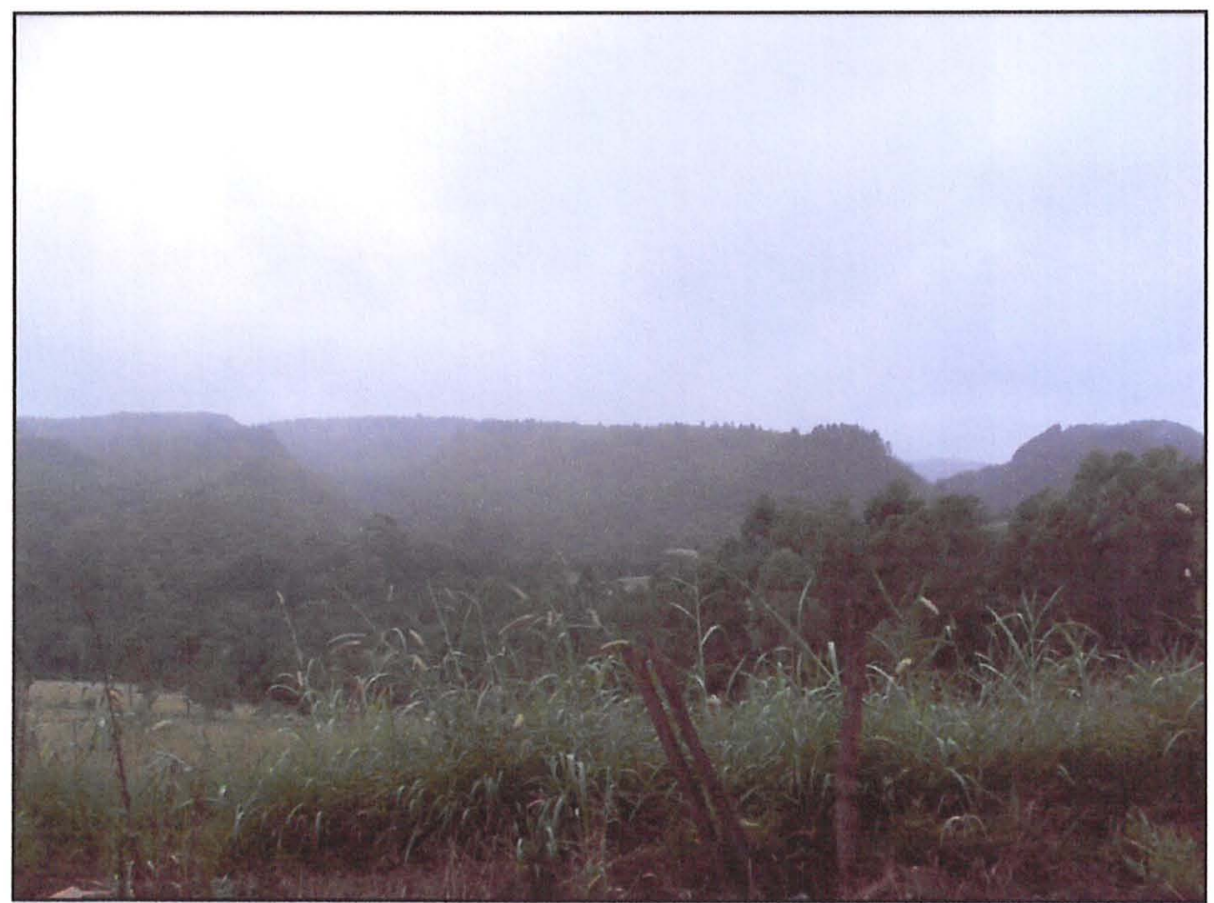

Figura 42. Geomorfologia da faixa norte. Morros em tabuleiro - testemunhos da Bacia do Paraná. 
Trabalhos pioneiros de Almeida, (1981), dizem respeito a uma extensão da Superfície de Aplainamento do Japi para a região de Capão Bonito, a qual pode ser observada nos morros em tabuleiro da figura 42. A Superfície de Aplainamento do Japi foi a unidade morfotectônica dominante da borda da sinéclise Paranaense no estado de São Paulo até pelo menos 80 a 60 milhões de anos atrás, quando da reativação tectônica da borda leste Paulista, a qual gerou o Rift Continental do Sudeste do Brasil e, muito provavelmente, tornou mais proeminente a escarpa da Serra do Mar.

A borda da escarpa da Serra de Paranapiacaba fornece uma excelente vista do relevo das partes baixas da planície do Ribeira, conforme o observado na figura 43 , tomada da borda da serra na entrada do parque Carlos Botelho.

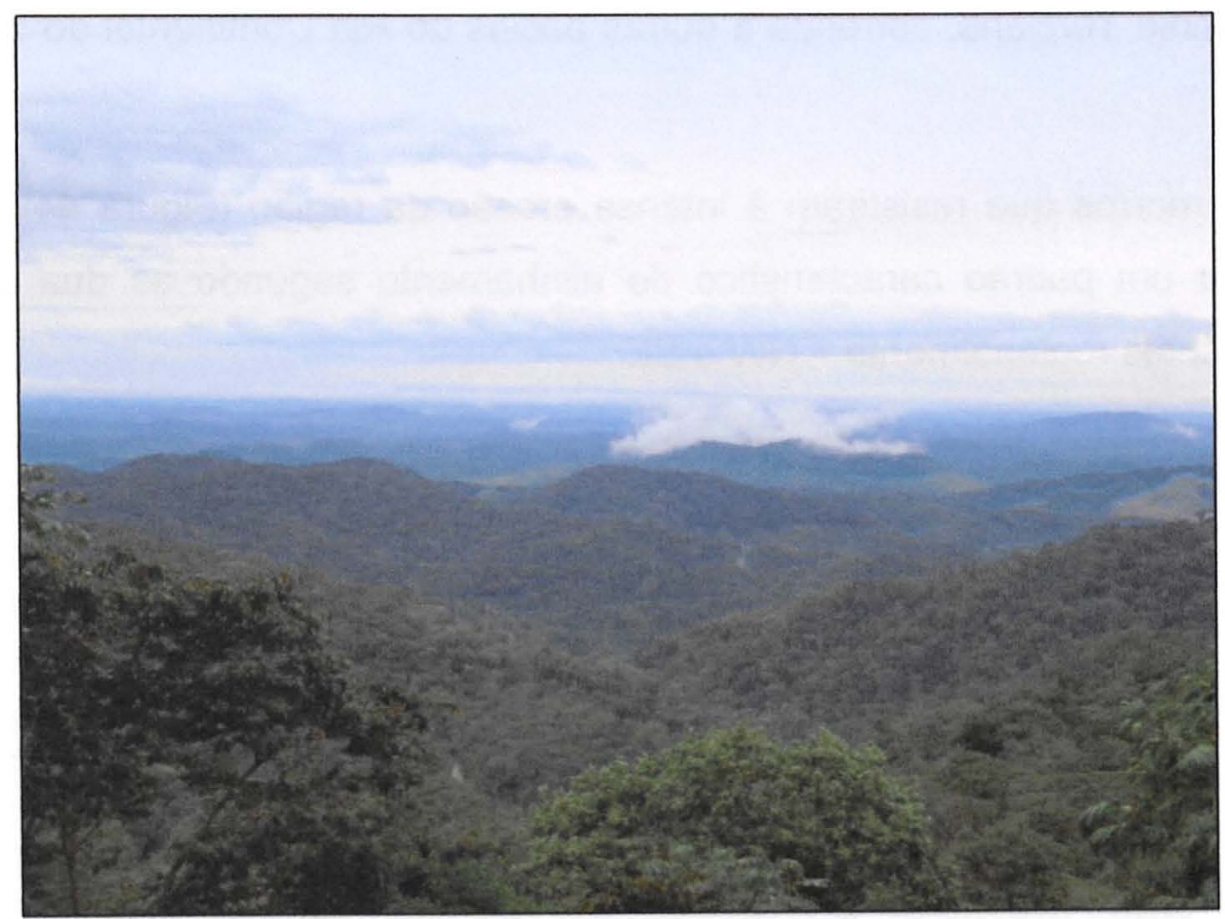

Figura 43. Vista para SE da escarpa da Serra de Paranapiacaba, próximo à entrada do parque Carlos Botelho. Notar a predominância de morros baixos arredondados, permeados por baixios planos planícies aluvionares - feição de erosão avançada

A região da Depressão do Baixo Ribeira, em vista na figura a cima, é caracterizada pela presença de uma extensa planície aluvionar instalada entre morros arredondados sustentados pelas litologias do embasamento metamórfico, principalmente do Complexo Embu. Esta planície aluvionar se desenvolveu com o 
rejuvenescimento do relevo, id est com o soerguimento da escarpa da Serra de Paranapiacaba.

O rejuvenescimento do relevo atual trouxe um aumento na taxa de erosão dos pontos cimeiros, resultando, em consonância com o clima úmido, em um rápido processo de entulhamento dos vales e planícies adjacentes.

O testemunho geológico destes eventos foi formalmente definido por Melo et al. (1989) e Melo (1990), que demonstrou que na Depressão do baixo Ribeira, hoje extensamente dominada por depósitos aluvionares dos afluentes do Ribeira de Iguape - e dele mesmo - outrora teriam sido locais de intensa deposição de sedimentos provenientes de fluxos de detritos das escarpas ao redor, em uma pequena bacia pelo autor denominada de Graben de Sete Barras, de idade supostamente Terciária, correlata a outras bacias do Rift Continental do Sudeste do Brasil.

Os morros que resistiram à intensa erosão da região (Figura 44) acabaram por formar um padrão característico de alinhamento segundo as dua $s$ direções predominantes regionalmente $-\mathrm{NW}$ e SE.

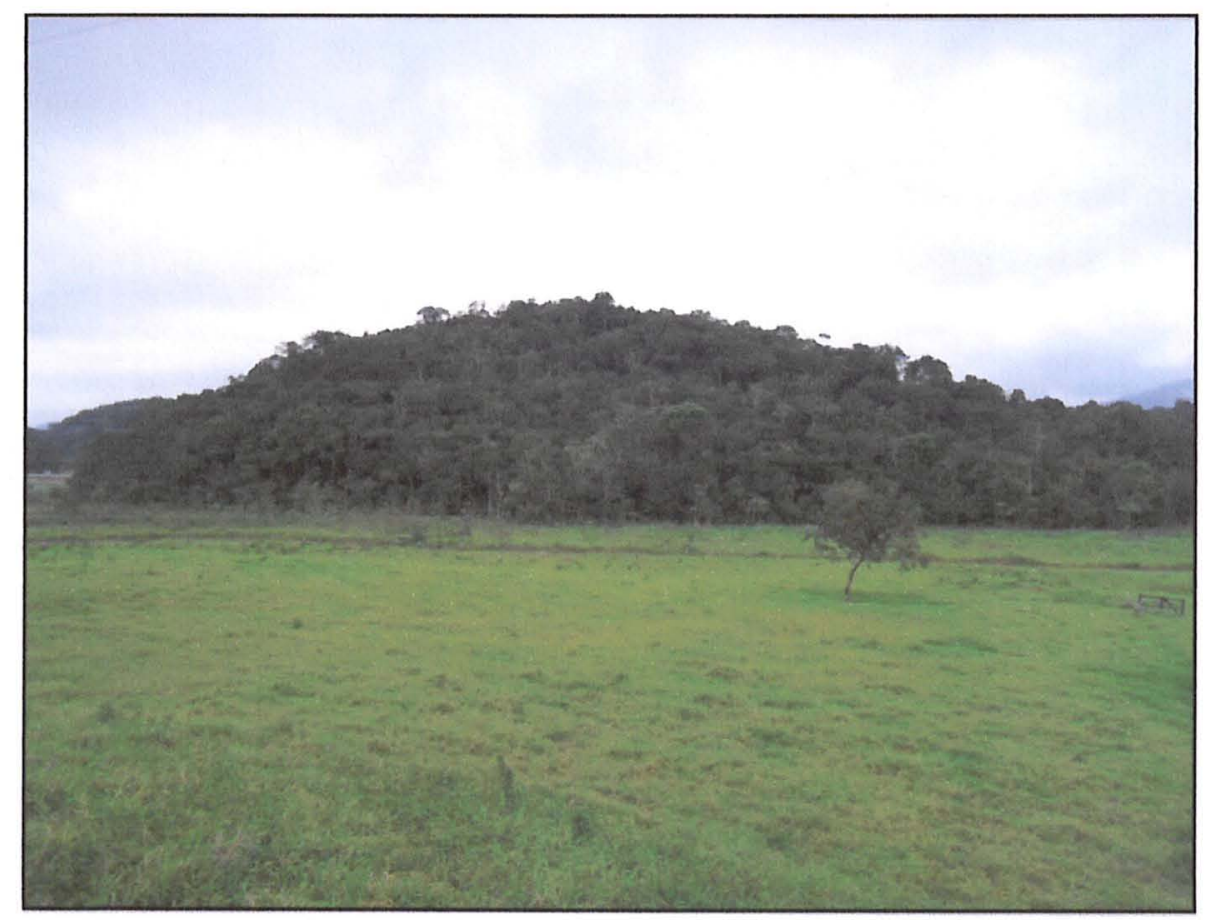

Figura 44. Um exemplar de morrote mamelonar comumente observado em toda a região da Depressão do Baixo Ribeira, próximo à escarpa da Serra de Paranapiacaba. Notar a extensa planície aluvionar desenvolvida em sua base, recoberta por pastagens. 
Os depósitos elúvio-aluvionares que se desenvolveram nos sopés destes morros - que raramente ultrapassam os $100 \mathrm{~m}$ de altitude - acabaram por gerar um padrão deposicional em treliça ortogonal, respeitando também as duas direções NW e SE, conforme pode ser observado na figura 45.

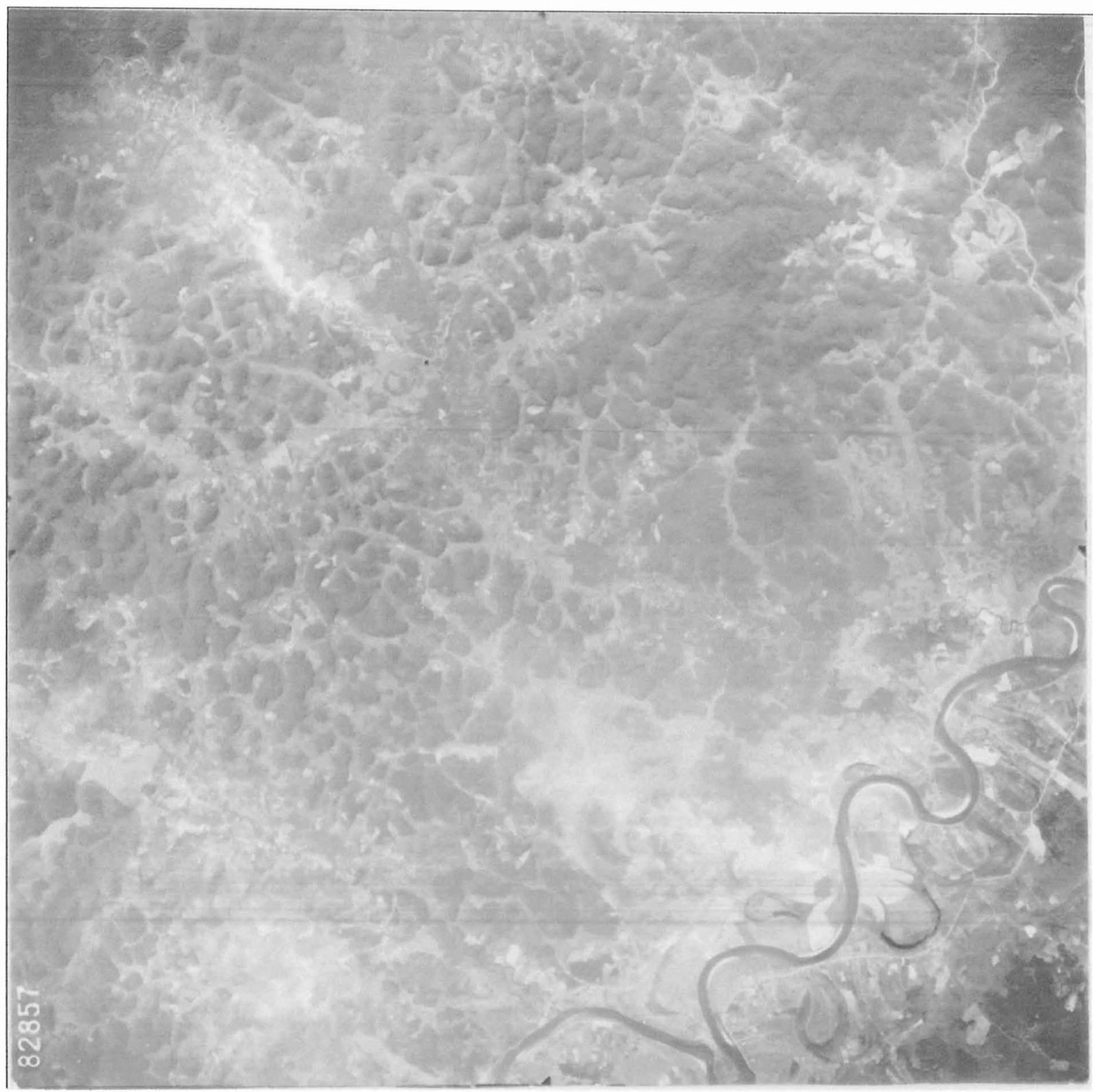

Figura 45. Típico relevo da região da Depressão Baixo Ribeira, escala aproximada 1:80.000. Notar o intenso fraturamento dos morros segundo as direções NE-SW e NW-SE e o desenvolvimentos de planícies aluvionares intersticiais, em padrão de treliça direcional. Na região SE da imagem, nota-se o rio Ribeira de Iguape e sua extensa planície aluvionar, com meandros abandonados. 
Uma visada final para norte fornece uma boa perspectiva da amplitude das feições geomorfológicas da área sul da Folha Capão Bonito, conforme o contemplado pela figura 46. No caso, observa-se uma extensa planície aluvionar alagada, permeada por morros mamelonares e, a fundo, a escarpa da Serra de Paranapiacaba. 


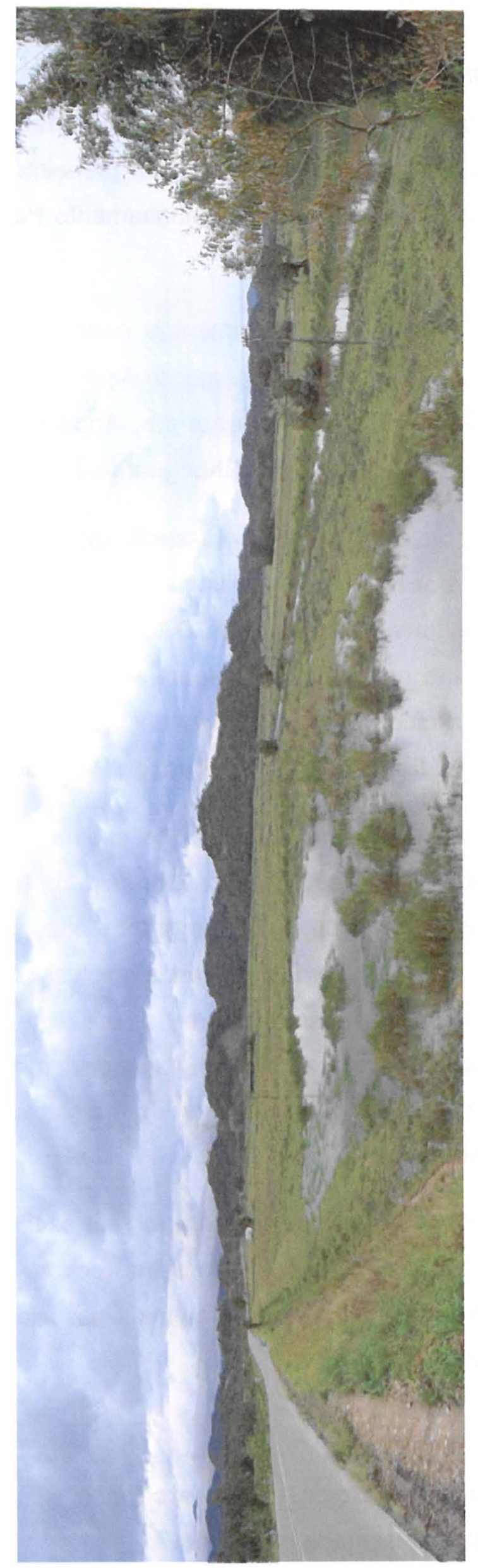

은

눌

के

娄

๕.

요

㐫

๑

क

은

강

ฮั

음

त $\frac{\pi}{0}$

密

ॠ

苋

के 离

(્)

(2)

ㅇํㄴ

है

은

뜌 음

D

물

응

总

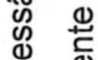

के

तु

인

:

䨌

त(

잉

응 믕

능 음

잉

离

뜬 $\frac{\mathrm{d}}{\mathrm{d}}$ 


\subsection{2 - DESCRIÇÕES LITOLÓGICAS E DE AFLORAMENTOS}

As descrições das litologias serão organizadas conforme a litoestratigrafia adotada e observada em campo. Serão descritos primeiramente os litotipos aflorantes na porção SE, considerados como o embasamento Paleoproterozóico do Supergrupo Açungui - Complexo Embu.

Em seguida, serão descritos os afloramentos onde ocorrem as unidades metassedimentares do mesoproterozóico (Supergrupo Açungui) - Formações Água Clara, Bairro da Serra, Betari, Sequencia Serra das Andorinhas - e do Grupo Votuverava - Formações Ribeirão das Pedras, Nhunguara e Piririca.

As unidades Neoproterozóicas metassedimentares da área são essencialmente pertencentes à Formação Iporanga, encontrada em uma faixa de cerca de $4 \mathrm{~km}$ de largura e extensa na direção NE-SW, cortando a folha toda em sua porção norte. Intrudindo estas unidades e as sobrejacentes (mesoproterozóicas), ocorrem diversos corpos graníticos dos quais se destaca o Batólito de Agudos Grandes, unidade sustentante da maior parte da Serra do Paranapiacaba na região.

Recobrindo os litotipos supracitados, jazem os sedimentos paleozoicos da Bacia do Paraná, que ocorrem em grande parte da extremidade Norte da folha. Esta região é marcada por seu relevo mais suave e pela grande quantidade de ocupação humana. Na folha Capão Bonito, foram observados exclusivamente os litotipos pelíticos da Formação Irati. Entrecortando toda a área de estudo ocorrem numerosos diques basálticos com direção NW-SE, associados ao alinhamento de Guapiara e interpretados como os alimentadores do magmatismo fissural jurocretáceo da Fm. Serra Geral.

Finalmente, no extremo SE da área, ocorrem rochas sedimentares terciárias associadas ao Graben de Sete Barras. Capeando estas rochas, restam apenas os depósitos aluvionares e de quebra de diques marginais associados à planície de inundação do Rio Ribeira de Iguape.

\subsubsection{1 - Embasamento Paleoproterozóico - Complexo Embu}

Engloba toda a região representada na figura 47: 


\section{AFLORAMENTOS - COMPLEXO EMBU}

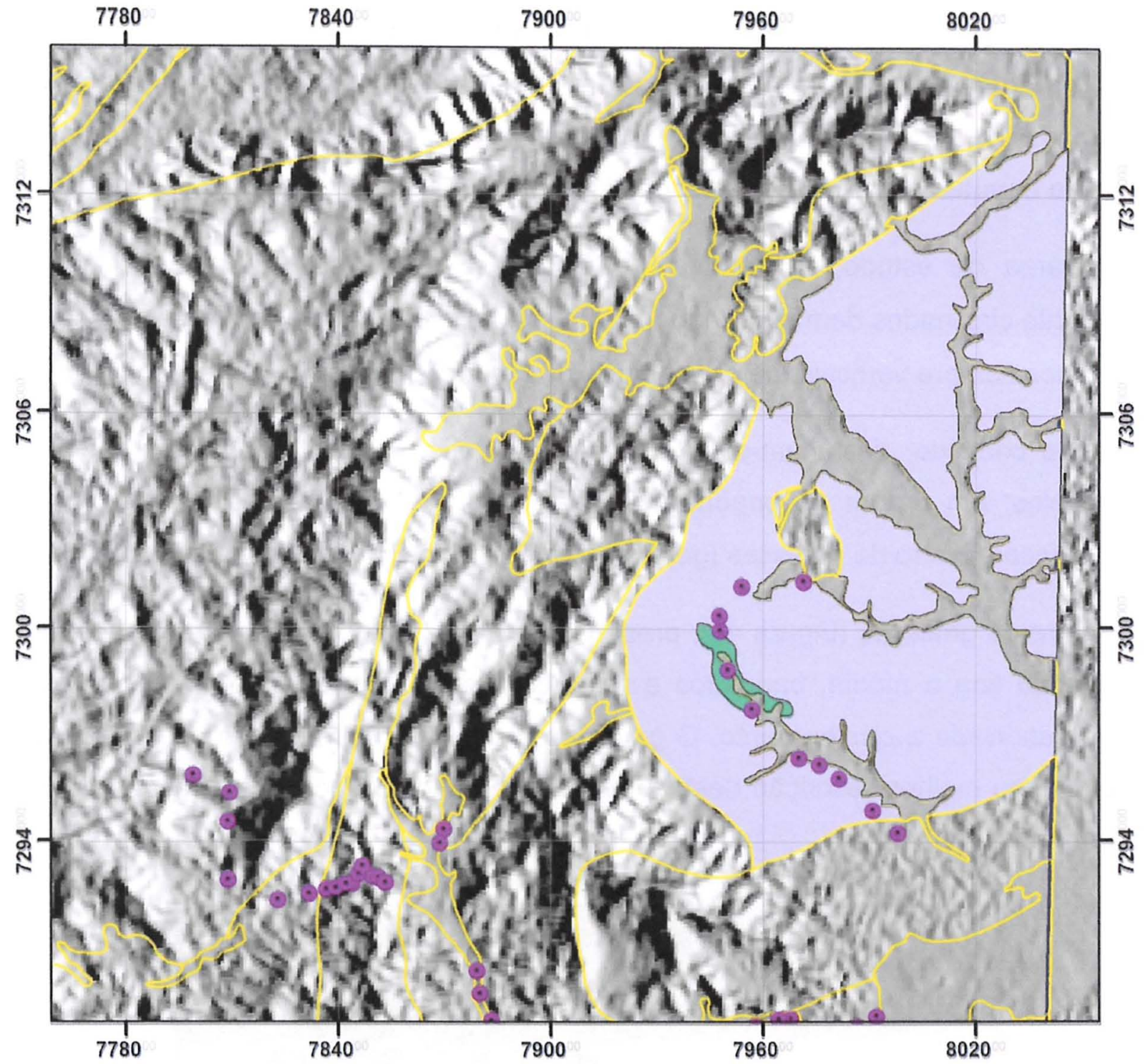

Complexo Embu e Pontos de afloramento sobre relevo sombreado obtido a partir de dados SRTM

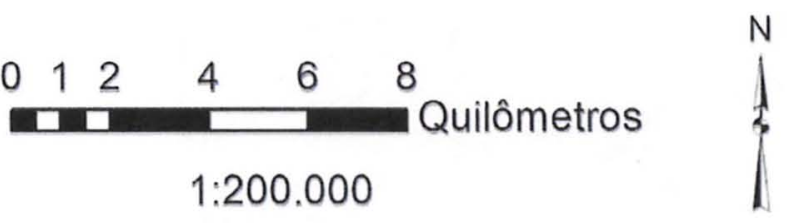

\section{Legenda}

\section{Litologias}

NP1egmb - Metabásicas Embu

NP1egm - Gnaisses e Migmatitos

Unidades Indiscriminadas

\{

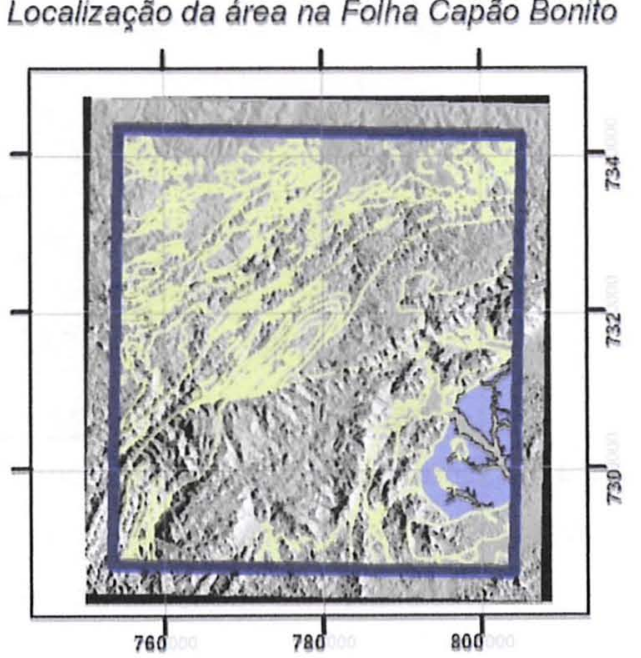


A região de afloramento do Complexo Embú é limitada à porção SE da área de estudo (Figura 47). Tem como principal característica os afloramentos muito intemperizados, restando muitas vezes apenas uma superfície saprolítica que preserva estruturas e minerais resistatos em meio a caulim.

$\mathrm{Na}$ área de estudo, os litotipos do Complexo Embu são de maneira geral fortemente cisalhados demonstrando uma foliação extremamente paralelizada e com mergulhos sempre verticais, de direção predominante NNE-SSW.

Neste contexto, destacam-se três principais litotipos reconhecidos em campo, sendo eles, em ordem de importância, os gnaisses, os anfibolitos, e os corpos metatexíticos dentro de gnaisses (geralmente de composição granodiorítica).

Dentre os gnaisses (Figura 48), predominam amplamente os biotita gnaisses de granulação fina a média, bandados e mais comumente com bandamento máficofélsico associado a cisalhamento. O grau de preservação ruim destes afloramentos impediu uma melhor descrição destes litotipos, sendo difícil inclusive a recuperação de amostras.

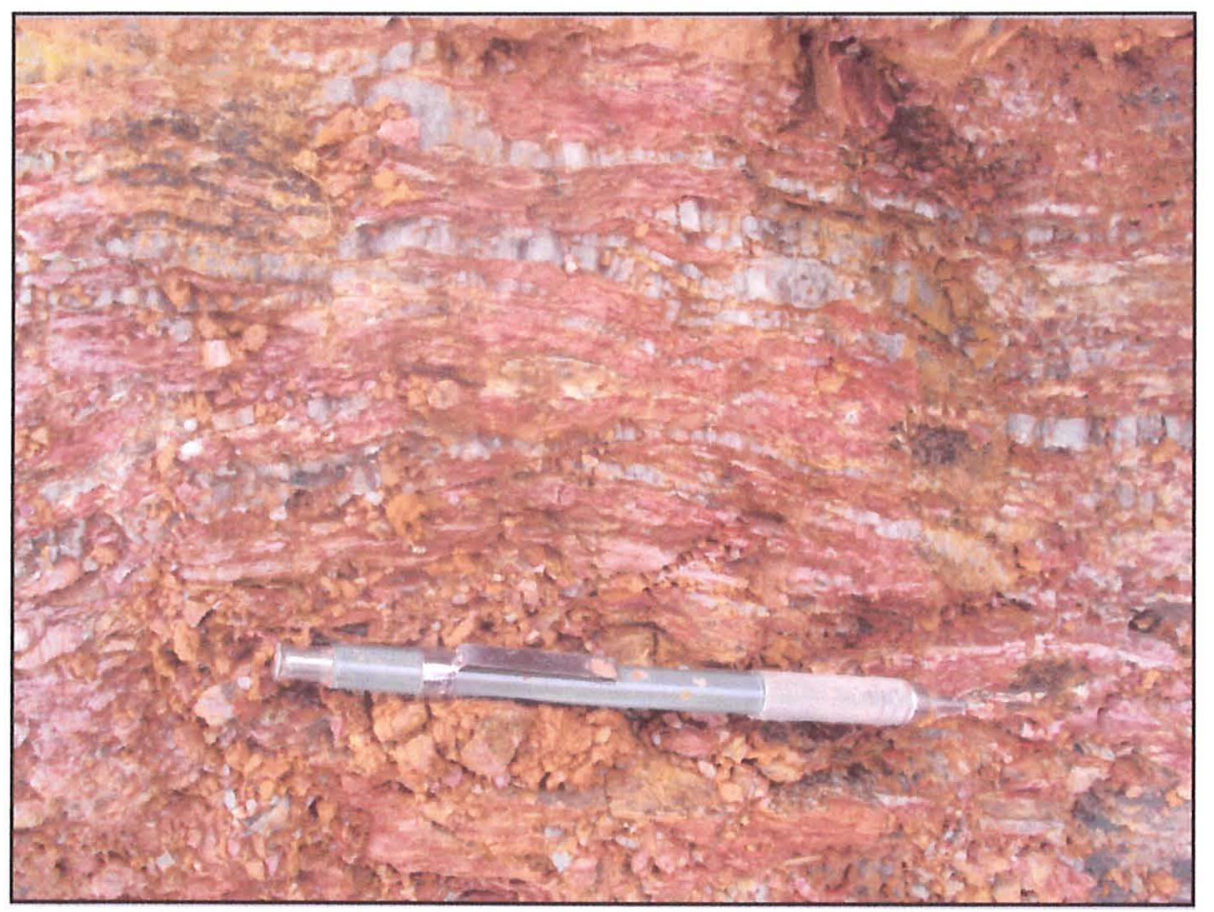

Figura 48. Gnaisses cisalhados do Complexo Embu, notar foliação fortemente paralelizada, além do bandeamento composicional acentuado pelo cisalhamento (bandas máficas alteradas para solo avermelhado, bandas félsicas ricas em quartzo mais resistentes). 
Bastante comuns entre os gnaisses são pequenos boudins ou lentes de rochas de composição básica. Muito provavelmente estas porções são fruto da segregação mineral ocorrida durante a migmatização e o cisalhamento, conforme pode ser observado na Figura 49.

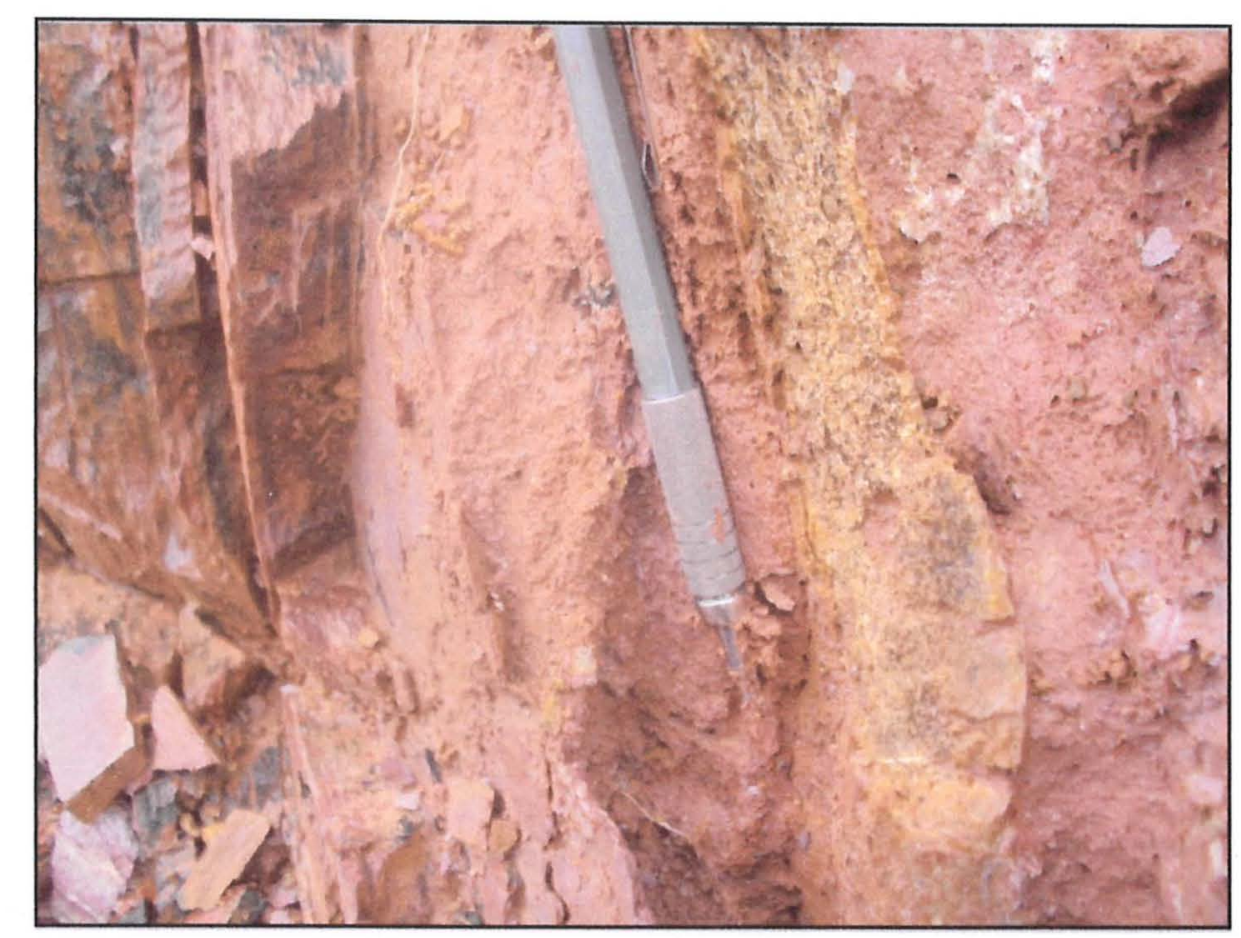

Figura 49: Porção de composição provavelmente básica entre os gnaisses cisalhados com Complexo Embu. Notar a cor de alteração amarelada típica de rochas básicas (alteração a caulim e óxidos de ferro).

Ocorrem ainda nesta unidade, bolsões de rochas metatexíticas, de composição félsica, evidenciando o maior grau metamórfico ao qual as rochas do Complexo Embu foram submetidas, provavelmente em torno do anfibolito superior. Nestas rochas não são encontrados minerais índices de metamorfismo que possam ser observados a olho nu, não sendo possível a confirmação desta informação. Estas porções podem variar entre monzogranitos e granodioritos (Figura 50).

Corpos expressivos de anfibolitos podem ser encontrados também dentro do Complexo Embu, sendo inclusive fonte de brita e cascalho para as estradas da região. Ocorre em um corpo bastante extenso, que foi individualizado durante o mapeamento realizado por este trabalho. Apresenta-se ora muito fraturado, ora maciço, e seus afloramentos são relativamente frescos quando comparados aos 
gnaisses. São de granulação fina a média, predominando anfibólios esverdeados e negros, com biotita e em pequena quantidade sulfetos metálicos (Figura 51).

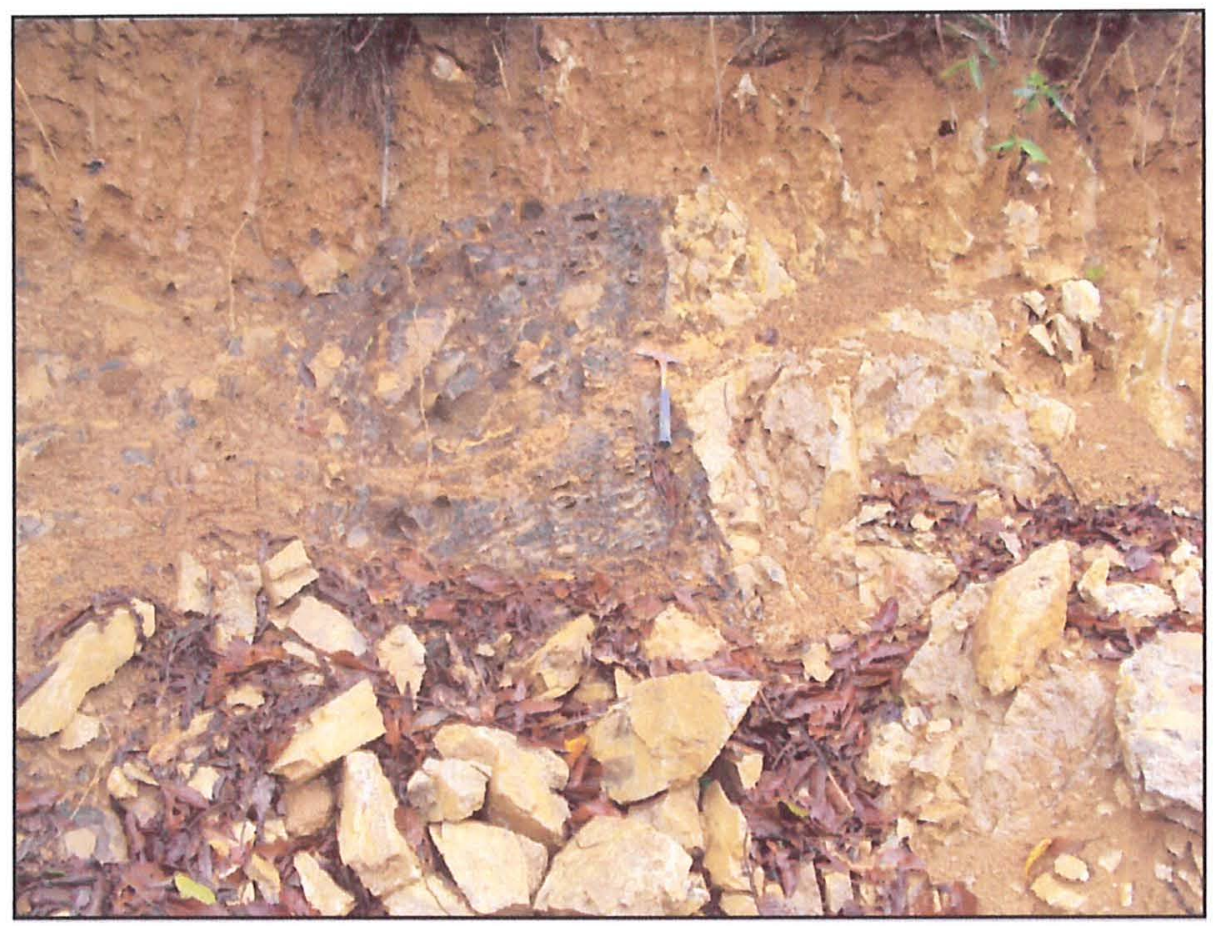

Figura 50. Bolsão metatexítico do Complexo Embu. Na parte esquerda da foto um dique de diabásio, feição muito comum em toda a extensão da folha Capão Bonito - Alinhamento do Guapiara.

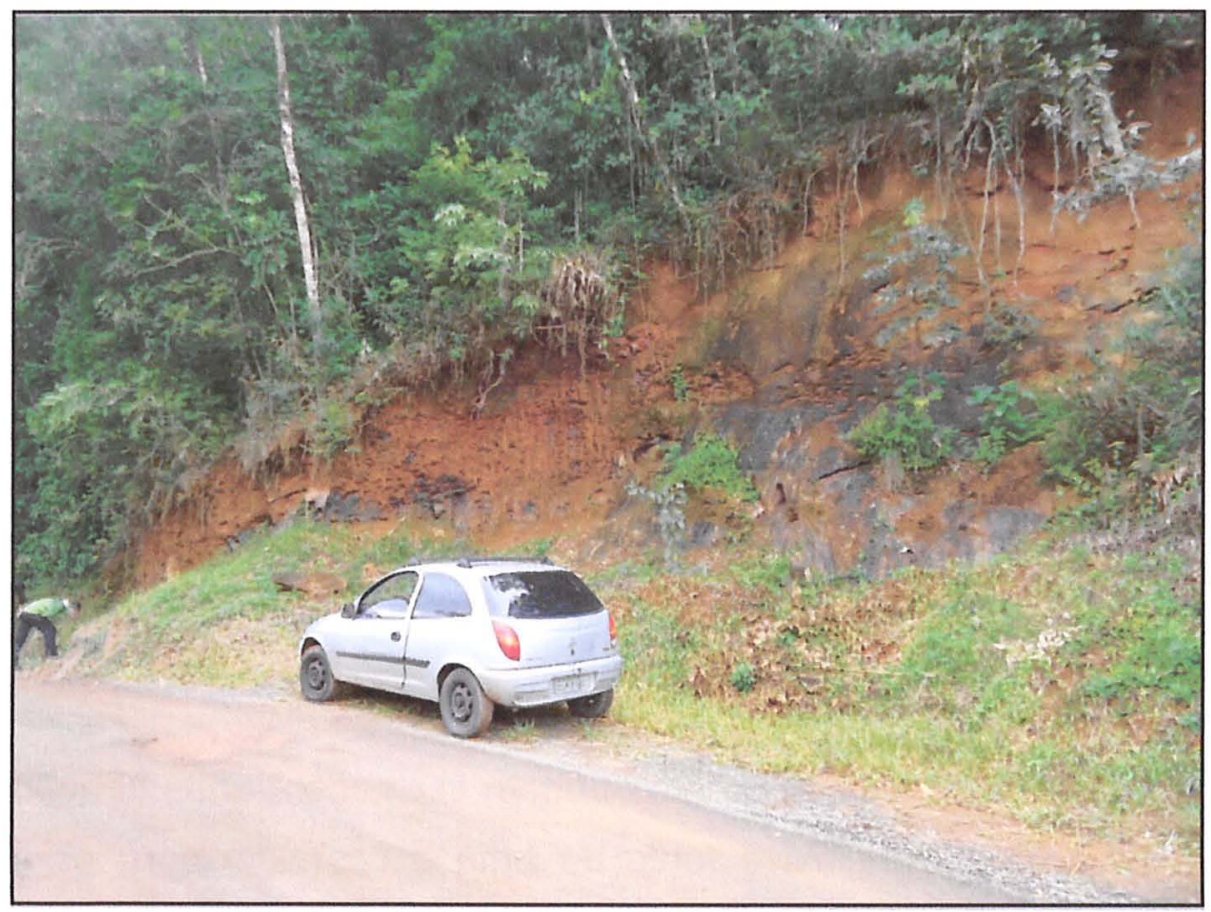

Figura 51. Afloramento dos metabasitos do Complexo Embu. 
O corpo de metabasitos que foi individualizado durante este trabalho de mapeamento pode ser observado no anexo $X$, mapa geológico em escala 1:100.000 da Folha Capão Bonito. Ele ocorre no extremo SE da folha, entre os migmatitos do Complexo Embu.

\subsubsection{2 - O Supergrupo Açungui}

A área de abrangência da folha Capão Bonito contempla a maioria dos litotipos pertencentes ao Supergrupo Açungui no estado de São Paulo, sendo encontradas na área as Formações Água Clara, Bairro da Serra, Betari, Sequencia Serra das Andorinhas, bem como o Grupo Votuverava - Formações Ribeirão das Pedras, Nhunguara e Piririca, todas atribuídas ao Mesoproterozóico. Entre estas unidades, destaca-se uma porção de rochas neoproterozóicas atribuídas às Formações Iporanga e Betari, além do Grupo Votuverava, as quais ocorrem em toda a extensão da folha a norte do Batólito de Agudos Grandes.

Durante os caminhamentos realizados nos campos deste trabalho, foi possível descrever litotipos pertencentes à maioria das unidades supracitadas, menos dos metarenitos da Formação Betari e dos pequenos núcleos de embasamento paleoproterozóico do Complexo Apiaí-Mirim, que ocorrem no extremo noroeste da área. A seguir, serão apresentadas as descrições macroscópicas dos principais litotipos aflorantes na região, individualizando-os por formação, bem como recortes do mapa geológico unidade a unidade, tal qual se observa na figura 52. 
Fig. 52. Afloramentos das Formações Água Clara e Betari

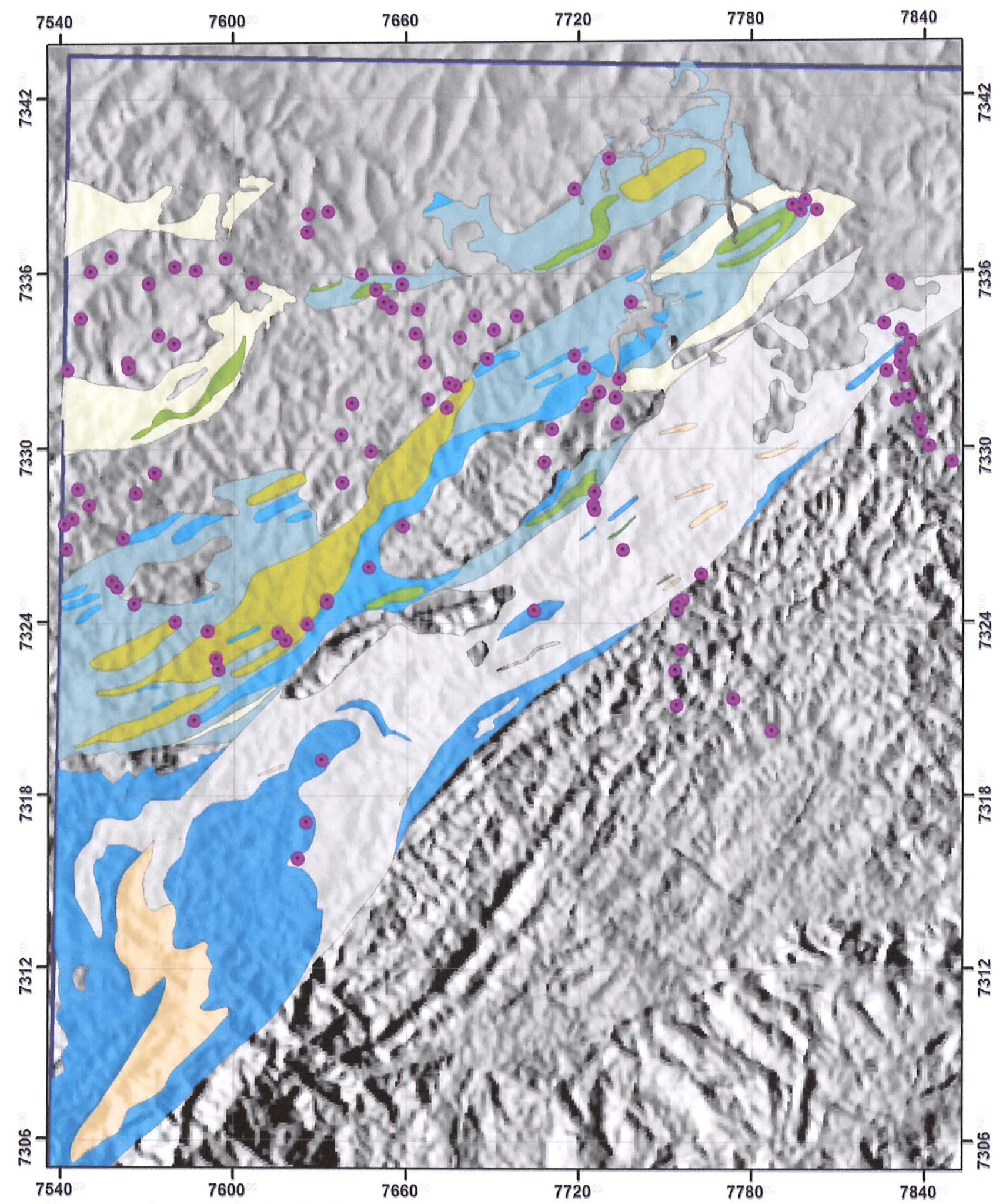

Supergrupo Açungui e Pontos de afloramento sobre relevo sombreado SRTM

Litologias

Fm. Agua Clara - Calcarios, calcio-filitos, metabásicas, quartzitos e quarzo-xistos MP1acc

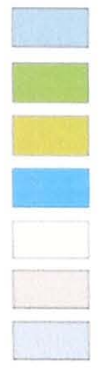

MP1accb

Fm. Bairro da Serra-màrmore

MP1accf
MP1accm

MP1acq

MP1acqx

MPbs

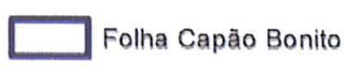

- Caminhamento

MP1acx

Fm. Betari - Arenitos, conglomerados, marmores, pelitos, metabásicas,

$\begin{array}{llllll}0 & 1 & 2 & 4 & 6 & 8\end{array}$
MPba

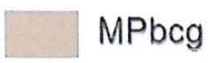

MPbm

MPbp

MPbpb

Quilômetros
Localização da área na Folha Capão Bonito

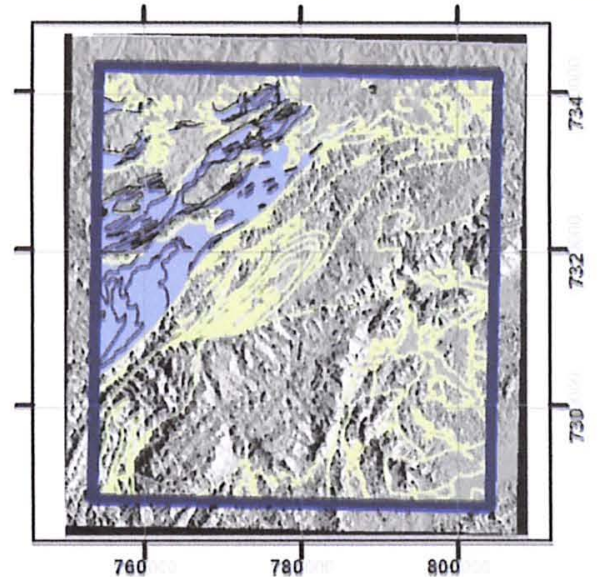




\subsubsection{A - Formação Água Clara}

A Formação Água Clara ocorre no extremo noroeste da Folha Capão Bonito e compreende uma sequência de rochas metassedimentares de deposição predominantemente química. São principalmente metacalcários, mármores, metamargas, cacioxistos e subordinadamente, quartzitos.

Todos os litotipos da Formação Água Clara apresentam foliações concordantes com a foliação geral de trend NE-SW, com caimento para SE e mergulhos geralmente em torno dos 50 a $60^{\circ}$. Em muitas ocasiões apresentam-se como calcários calcíticos impuros, com lentes de material pelítico (figura 53) onde é possivel observar uma foliação subparalela à regional, de direção ENE-SSW, e mergulho para ESE com inclinações da ordem dos $70^{\circ}$, refletindo pelo menos dois eventos deformacionais.

Nas lâminas mais silto-arenosas, podem ser encontradas ainda lineações de estiramento mineral com direção de transporte para WNW (Figura 54).

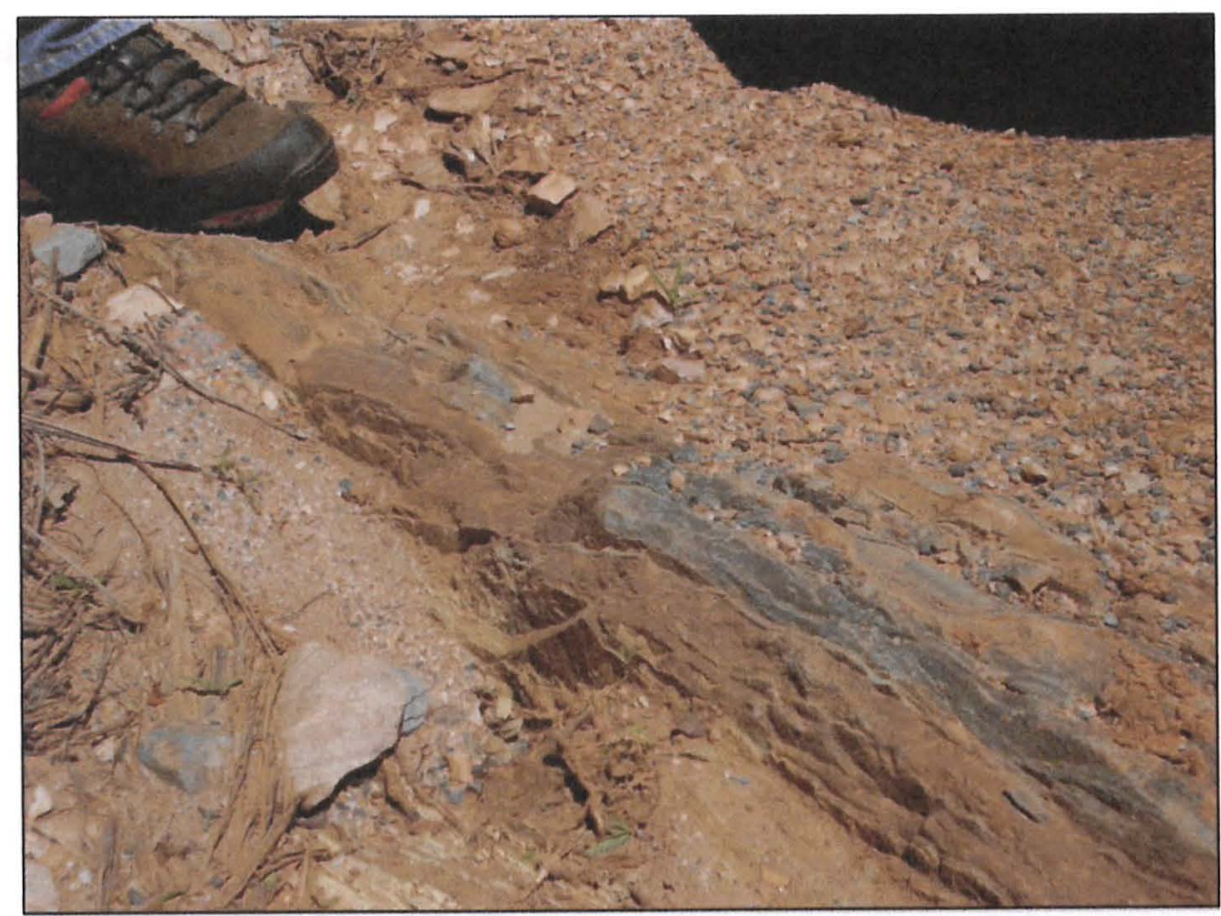

Figura 53. Leito de metacalcário calcítico (acinzentado) entre porções pelíticas da Formação Água Clara. 


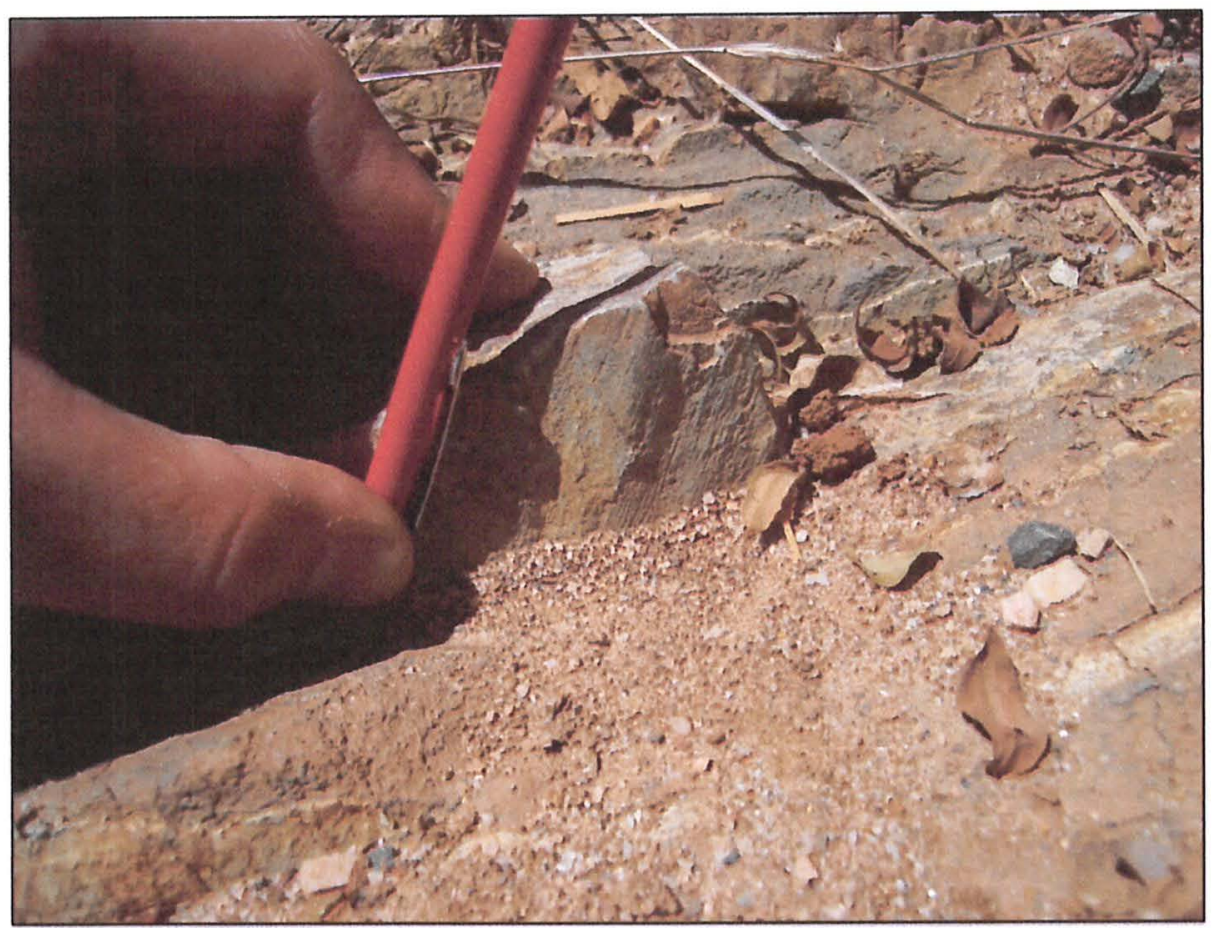

Figura 54. Lineação de estiramento mineral aferida em 350/89

Em relação ao metamorfismo desta Formação, é notável a baixa quantidade de recristalização, evidenciando um grau de metamorfismo muito moderado, responsável por preservar estruturas sedimentares reliquiares. Nesta unidade, destacam-se algumas porções de mármores escuros portando cristais de sulfetos (provavelmente pirita), sugerindo a deposição em ambiente com baixa oxigenação mares profundos (figura 55).

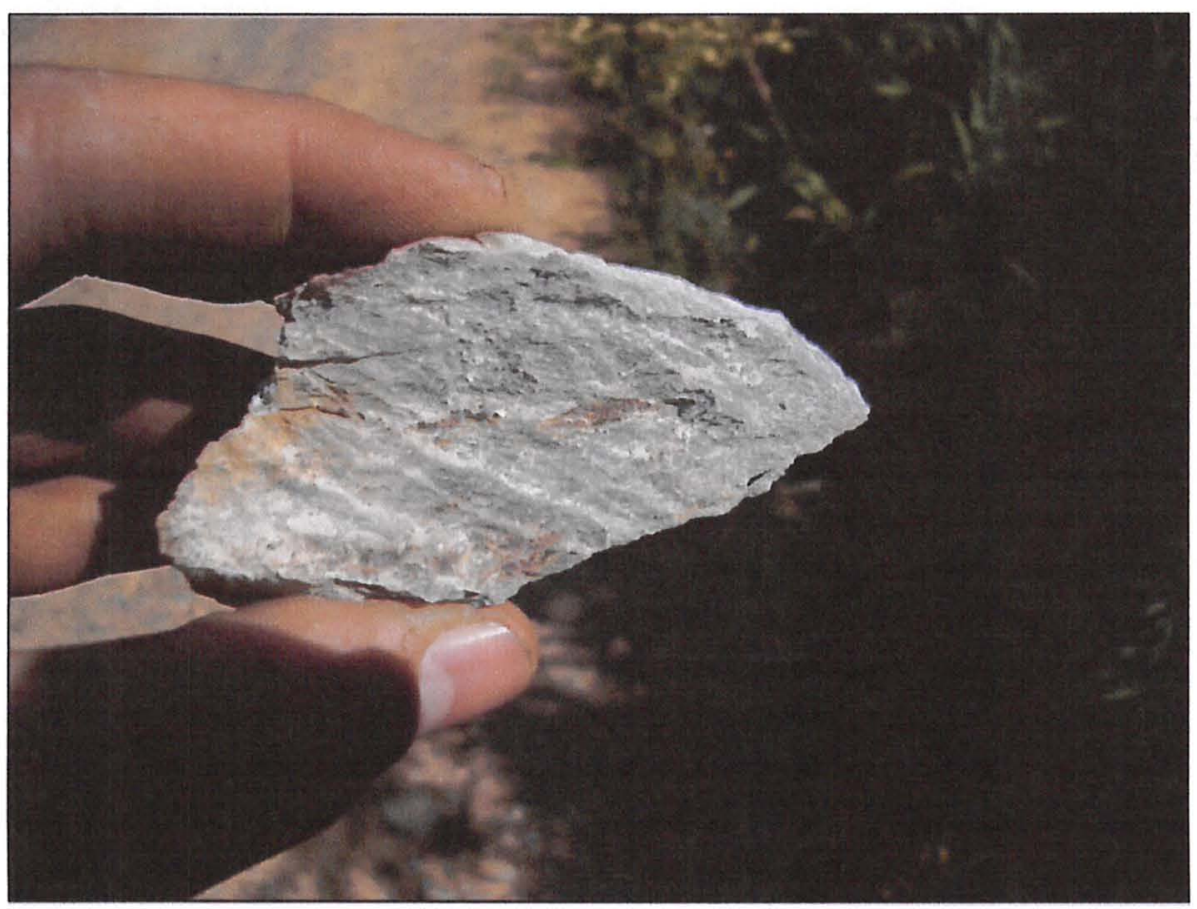

Figura 55 Leitos amarronzados por oxidação de sulfetos (pirita), evidência de deposição química em ambiente redutor. 
Esta Formação, juntamente com a Formação Bairro da Serra, constitui o pacote de sedimentação química da 'Bacia Açungui' aflorante na região da Folha Capão Bonito. Estas rochas são de extrema importância econômica para a região, que tem grandes empreendimentos mineiros para extração de calcário para a fabricação de cimentos.

\subsubsection{B - Formação Betari}

A Formação Betari, ou Sequência Deposicional Betari, configura a faixa sul do Supergrupo Açungui, com espessura bastante regular em torno dos $4,5 \mathrm{~km}$ ao longo de toda a extensão. É composta de uma seqüência metassedimentar de baixo grau metamórfico, de caráter predominantemente clástico, mas com expressivos corpos de sedimentação química e clastico-química (Formação Bairro da Serra).

São essencialmente intercalações areno-pelíticas, ardósias e conglomerados, sendo caracterizadas por Pires (1988) como retrogradacional, associada a epsódio transgressivo, e representada por sistemas turbidíticos do tipo II e III. As rochas mais comuns são os metapelitos finos, metarritimitos e metarenitos, conforme se observa na figura 56.

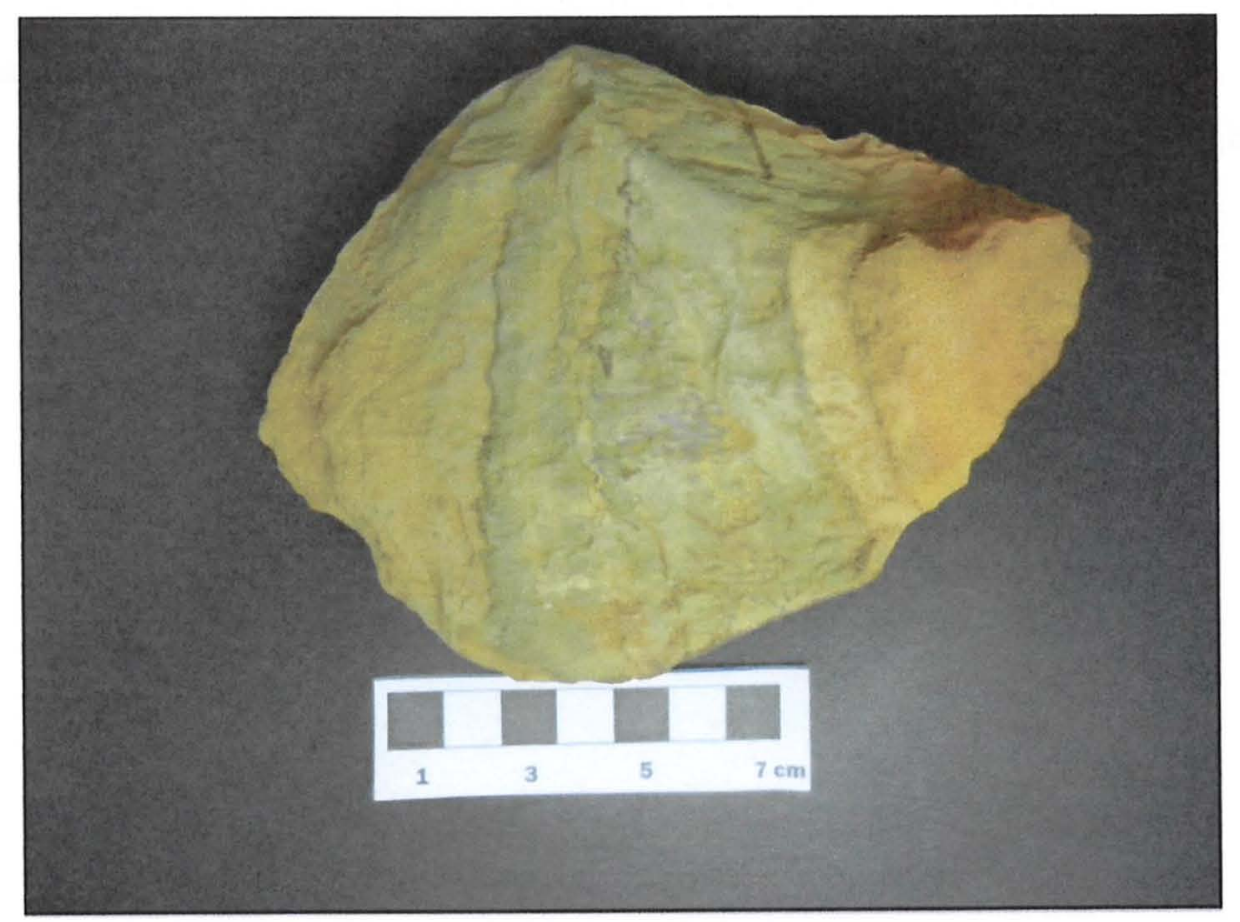

Figura 56. Metapelito comum na Formação Betari, unidade Pelítica. Os acamementos sedimentares primordiais $\left(\mathrm{S}_{0}\right)$ estão preservados. 
Separa da porção clástica ocorre a Formação Bairro da Serra, representante da deposição química da Sequência Betari. Esta formação ocorre imediatamente a sul da Formação Água Clara, e é composta essencialmente por rochas de sedimentação clasto-química sendo as predominantes, mármores e metacalcarenitos.

Diferem dos litotipos da Formação Água Clara por seu grau metamórfico ligeiramente maior - evidenciado por seus cristais mais soldados resultando em mármores com maior recristalização - além de uma estruturação também distinta.

Enquanto as rochas da Formação Água Clara ocorrem bastante paralelizadas segundo a direção NE-SW, os litotipos da Formação Bairro da Serra se apresentam, pelo menos na região do caminhamento, com direções de acamamento sedimentar $\mathrm{S}_{0}$ com mergulho para SW, e direção NW-SE. Este comportamento é inclusive refletido no desenho de suas unidades em mapa, discordantes do esperado para as litologias do Grupo Açungui, geralmente bastante paralelizadas segundo as zonas de cisalhamento regionais.

A figura 57 mostra um mármore da Formação Bairro da Serra. São, em geral, bem mais puros do que a Formação Água Clara, com coloração cinza a cinza escuro, e, em alguns casos, apresentam acamamento sedimentar preservado na forma de leitos de deposição clástica, conforme o observado no metacalcarenito da Figura 58. 


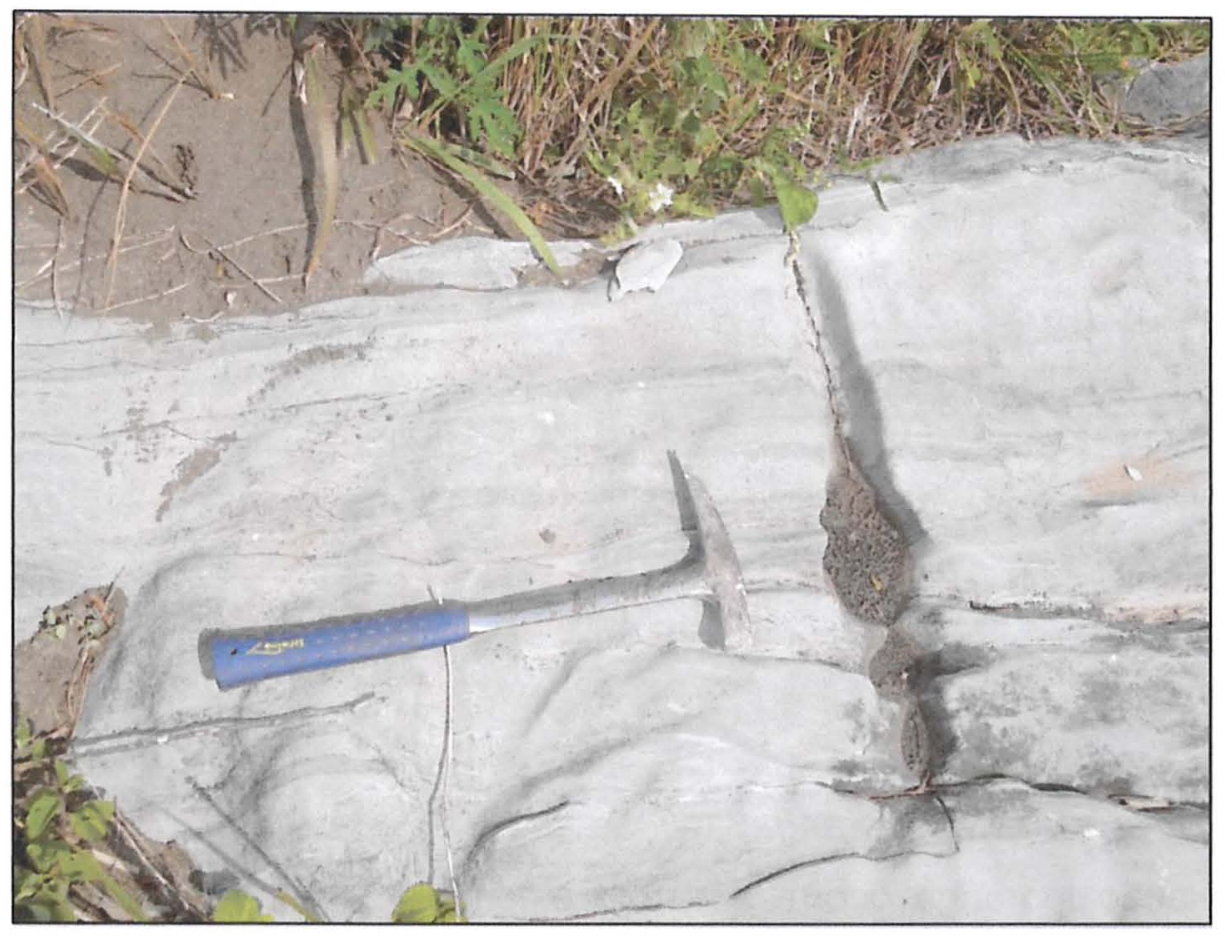

Figura 57. Metapelito comum na Formação Betari, unidade Pelítica. Os acamementos sedimentares primordiais $\left(\mathrm{S}_{0}\right)$ estão preservados.

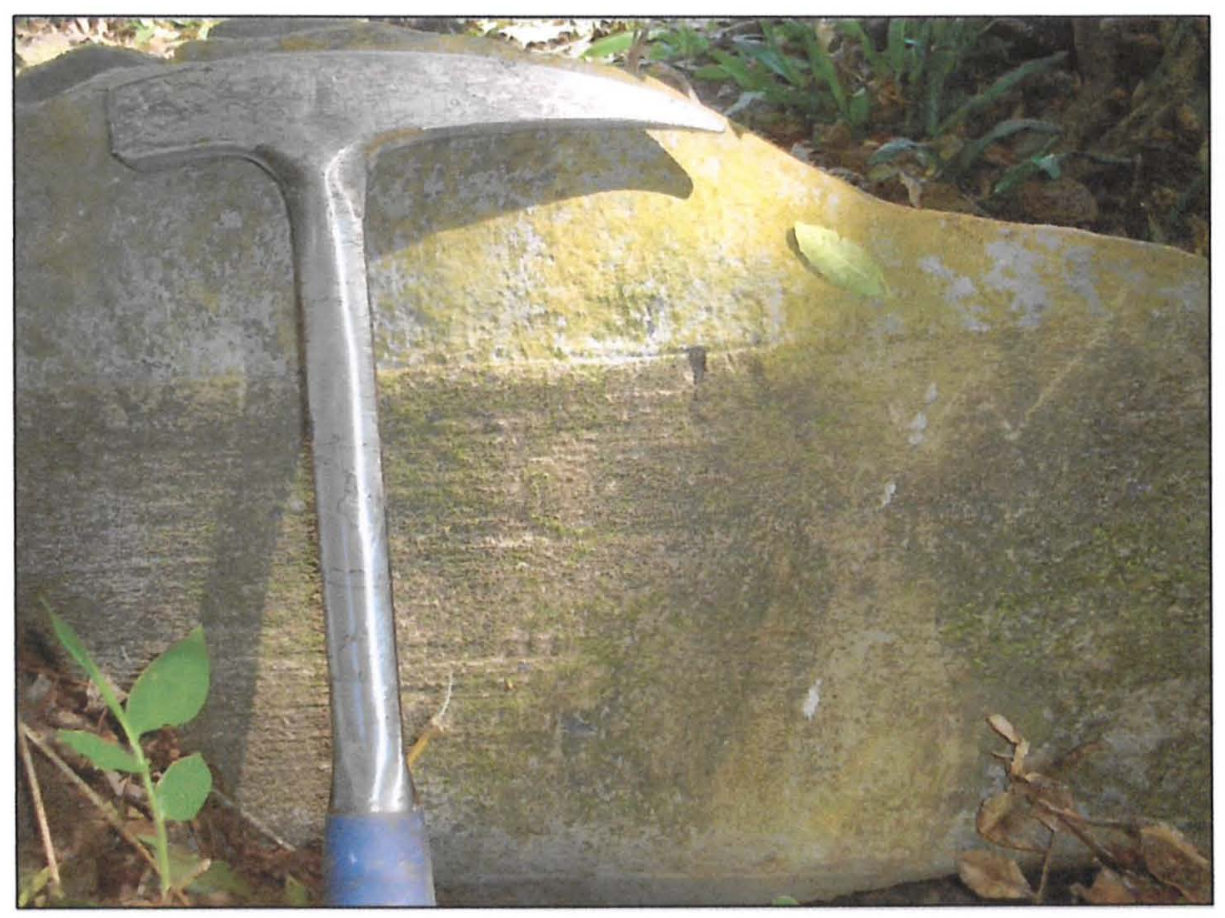

Figura 58. Metapelito comum na Formação Betari, unidade Pelítica. Os acamementos sedimentares primordiais $\left(\mathrm{S}_{0}\right)$ estão preservados. 
8.4.2.2C - Formação Iporanga

A Formação Iporanga ocorre em uma extensa faixa desde a região de Iporanga (região nordeste da folha Apiaí, a oeste da área de estudo), até a porção nordeste da Folha Capão Bonito, configurando mais de $100 \mathrm{~km}$ de afloramentos em uma faixa de até $10 \mathrm{~km}$ de extensão (na porção extremo NE, já onde se inicia a cobertura Paleozoica).

Uma ideia da extensão desta Formação pode ser tida na figura 59, região de afloramento da Formação Iporanga na Folha Capão Bonito. 


\section{AFLORAMENTOS - FORMAÇÃO IPORANGA}

Fig. 59

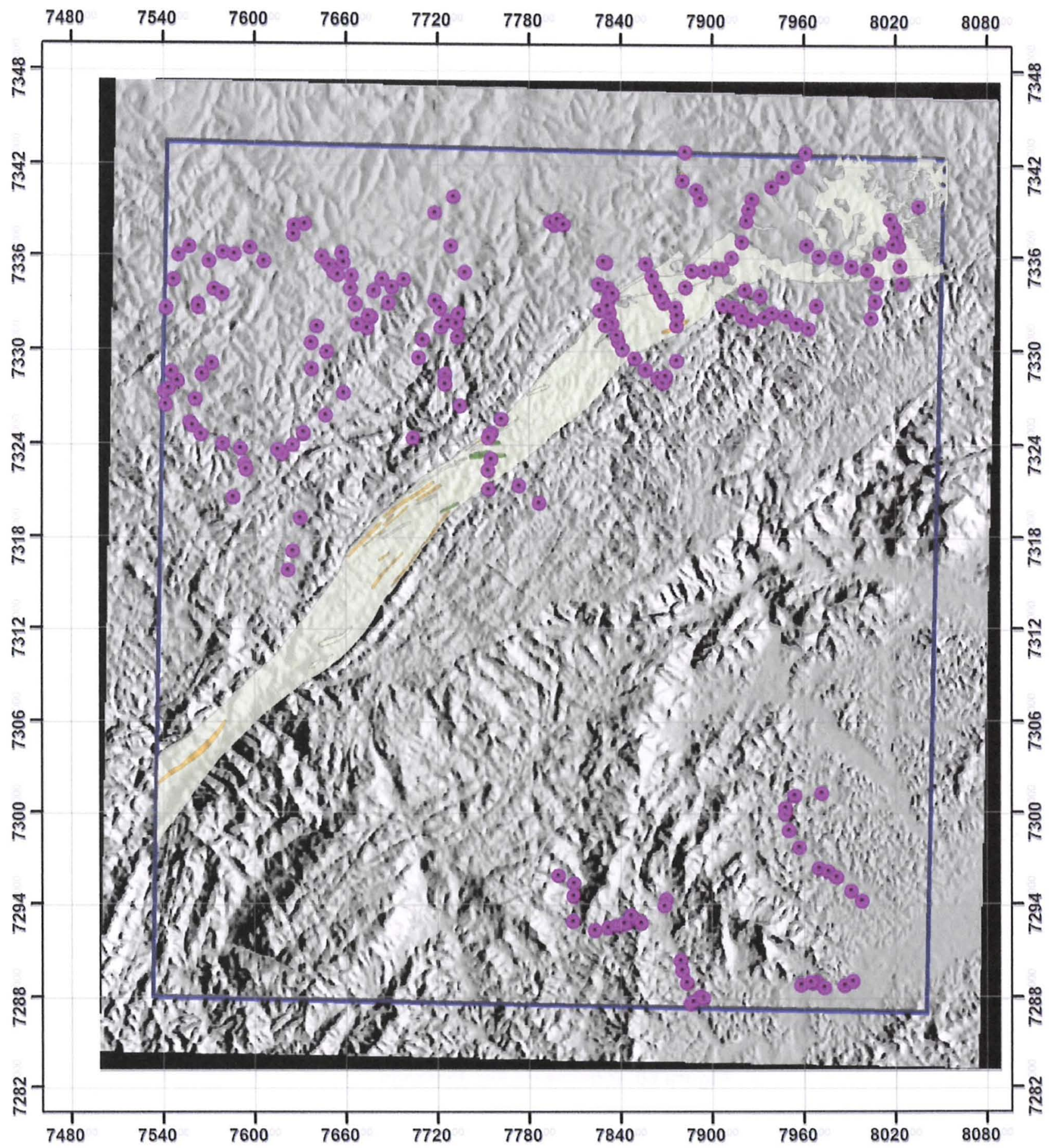

Supergrupo Açungui e Pontos de afloramento sobre relevo sombreado SRTM

\section{Litologias}

Fm. Iporanga - Sequencia deposicional vulcanoclàstica Neoproterozóica, predominando conglomerados, quartzitos e pelitos.

(1)

NP3ippb

NP3ippcg

- Caminhamento

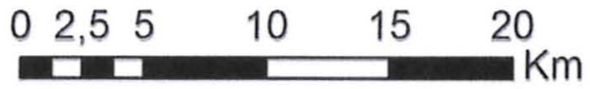

Localização da àrea na Folha Capão Bonito

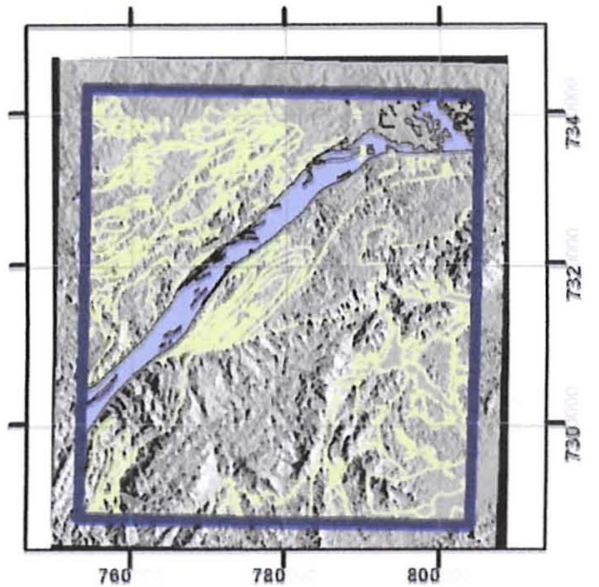


A Formação Iporanga é composta pela faixa de metassedimentos contígua à Formação Betari, em sua porção sul. Distingue-se dele por sua sedimentação exclusivamente clástica, à qual se associam alguns níveis de rocha vulcânica, além de sua idade Neoproterozóica.

A unidade amplamente dominante desta formação na área de estudo é composta de metapelitos com intercalações arenosas, demonstrando feições sedimentares preservadas na maioria dos afloramentos. Neste contexto, podem variar de faixas exclusivamente ritmíticas (figura 60) - principalmente na borda norte e noroeste do corpo - até porções conglomeráticas (figura 61).

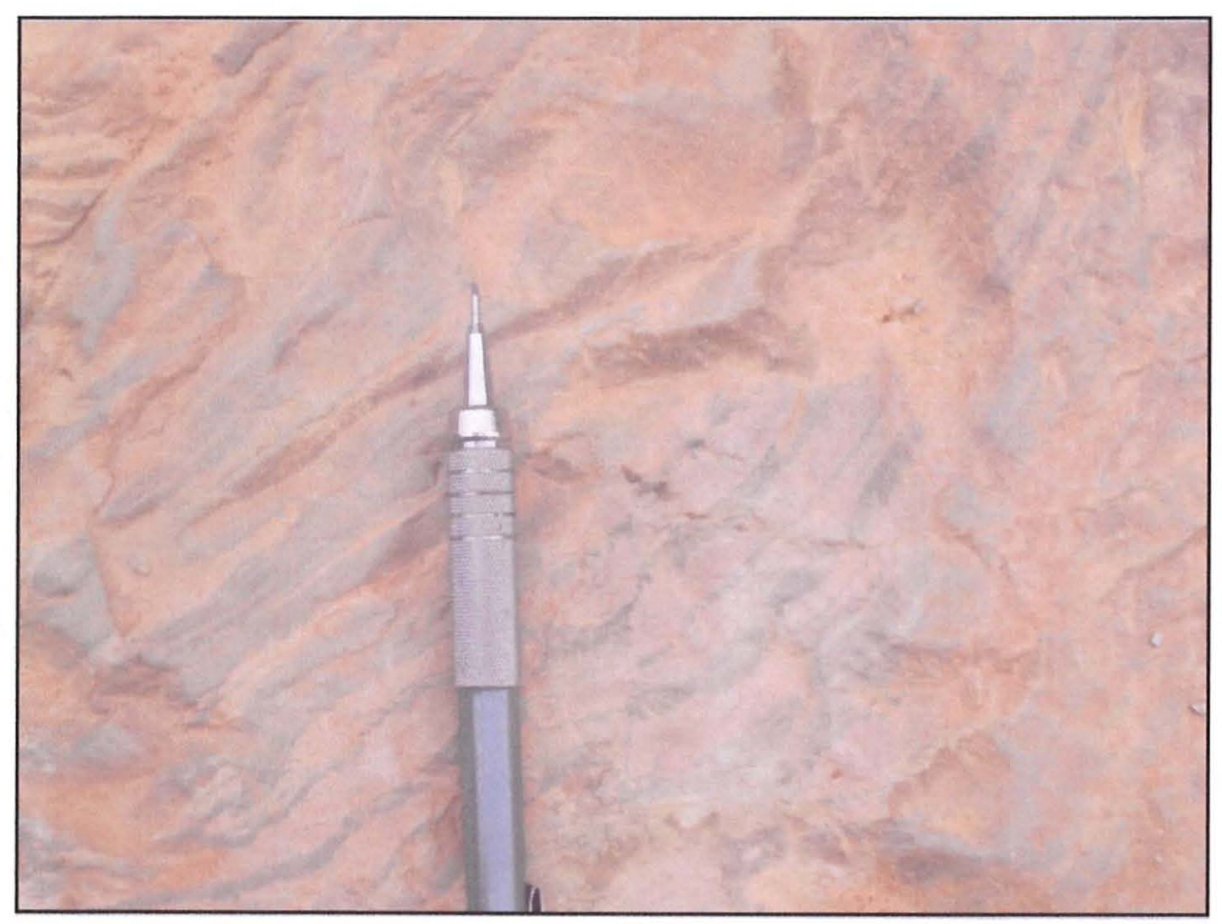

Figura 60. Ritmitos da Fm. Iporanga.

Destaca-se nesta unidade a presença de diversas feições de sedimentação em região de transição de ambiente marinho intermediário a profundo, provavelmente envolvendo correntes de turbidez e retrabalhamento intraformacional (autobrechamento), conforme as figuras 62 e 63 


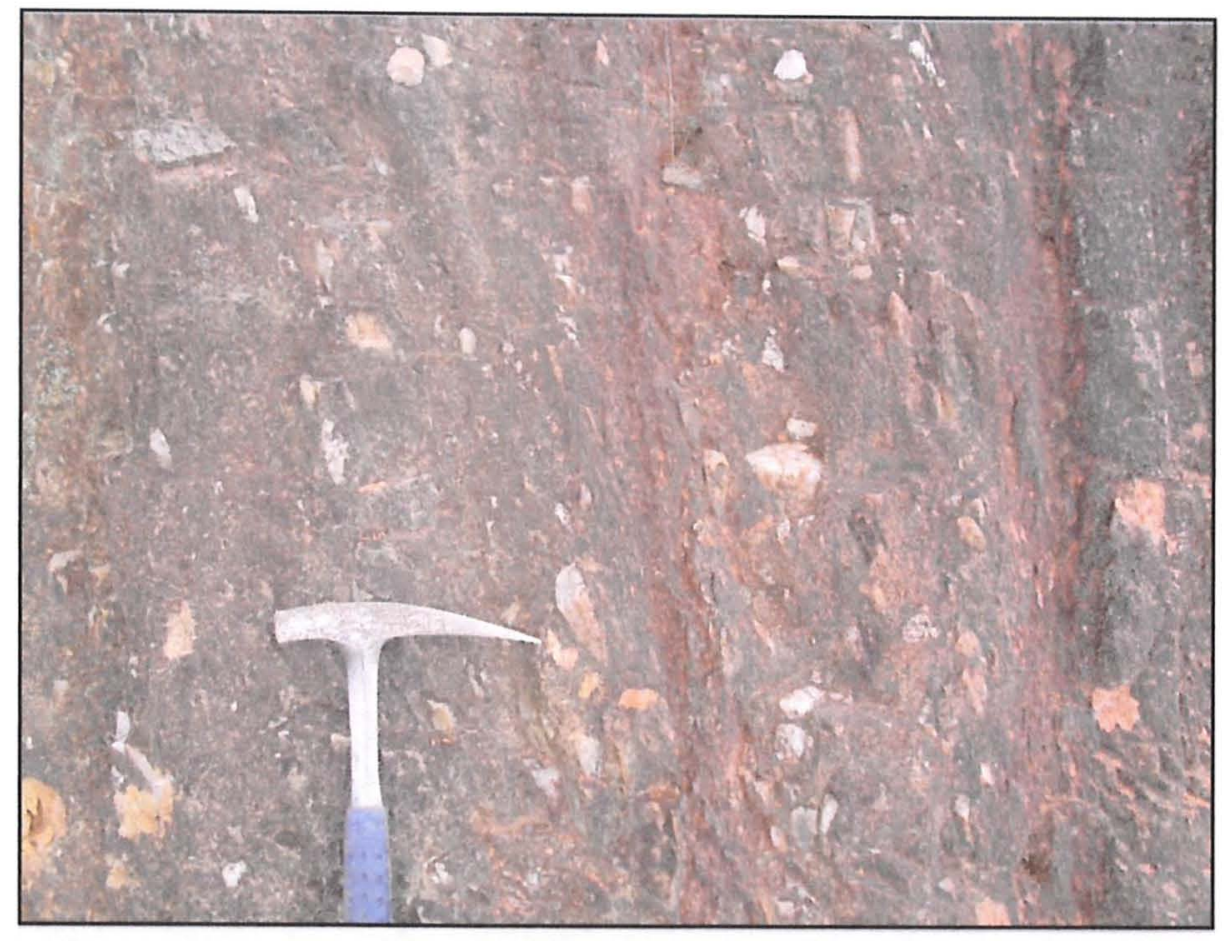

Figura 61. Conglomerados suportados pela matriz - Fm. Iporanga.

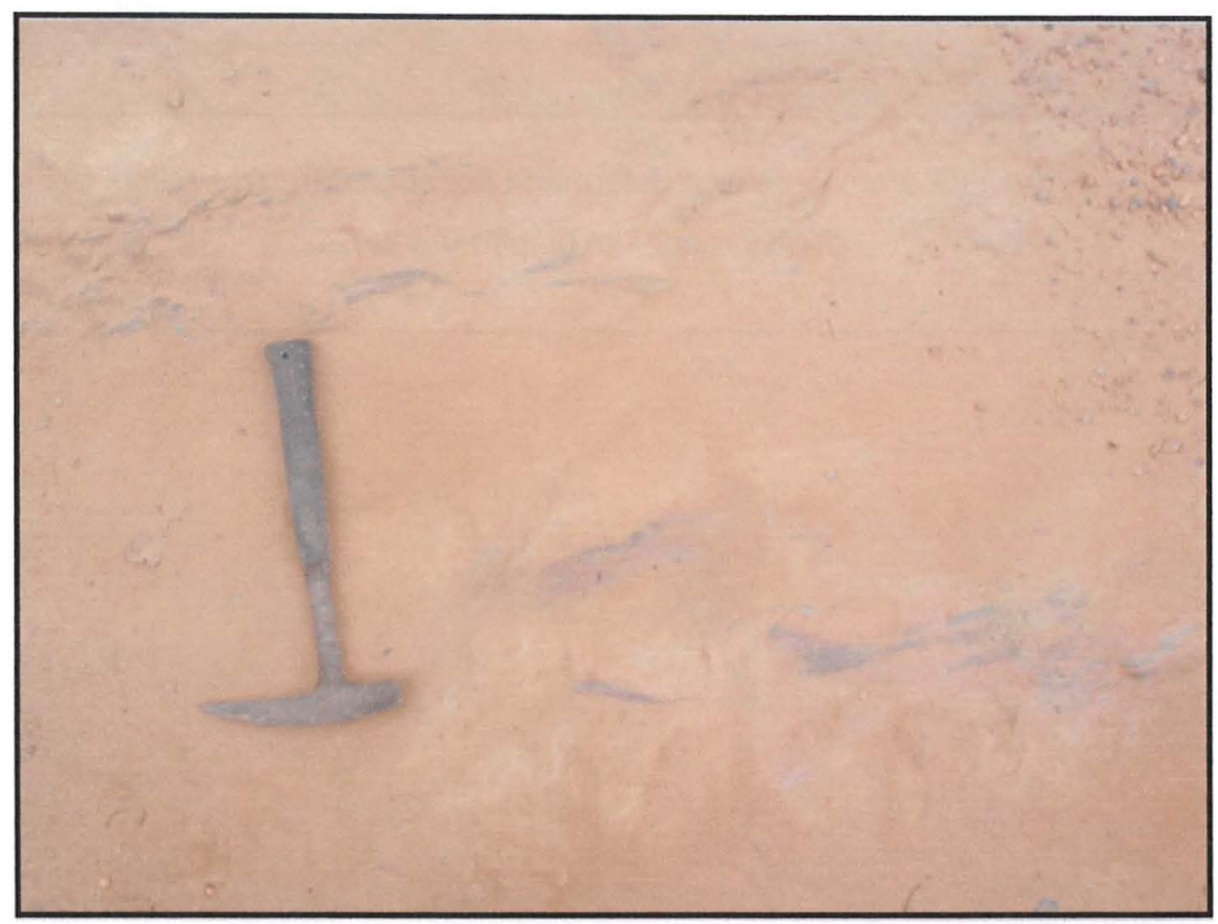

Figura 62. Metarenitos com porções pelíticas retrabalhadas por correntes de turbidez - feição de autobrechamento.

Estes indícios sugerem uma sedimentação em ambiente turbidítico próximo a uma plataforma continental ou a arcos de ilhas, onde há altos gradientes e predominam, em direção ao mar profundo, canais subaquosos. $\mathrm{O}$ ambiente era ainda tectonicamente ativo, com presença de magmatismo (figura 64). A deposição 
turbidítica na área parece ser próxima à borda continental pela dominância de arenitos em relação a lamitos e pela presença de lentes de arenitos médios a grosseiros, que acabam por retrabalhar camadas sobrejacentes.

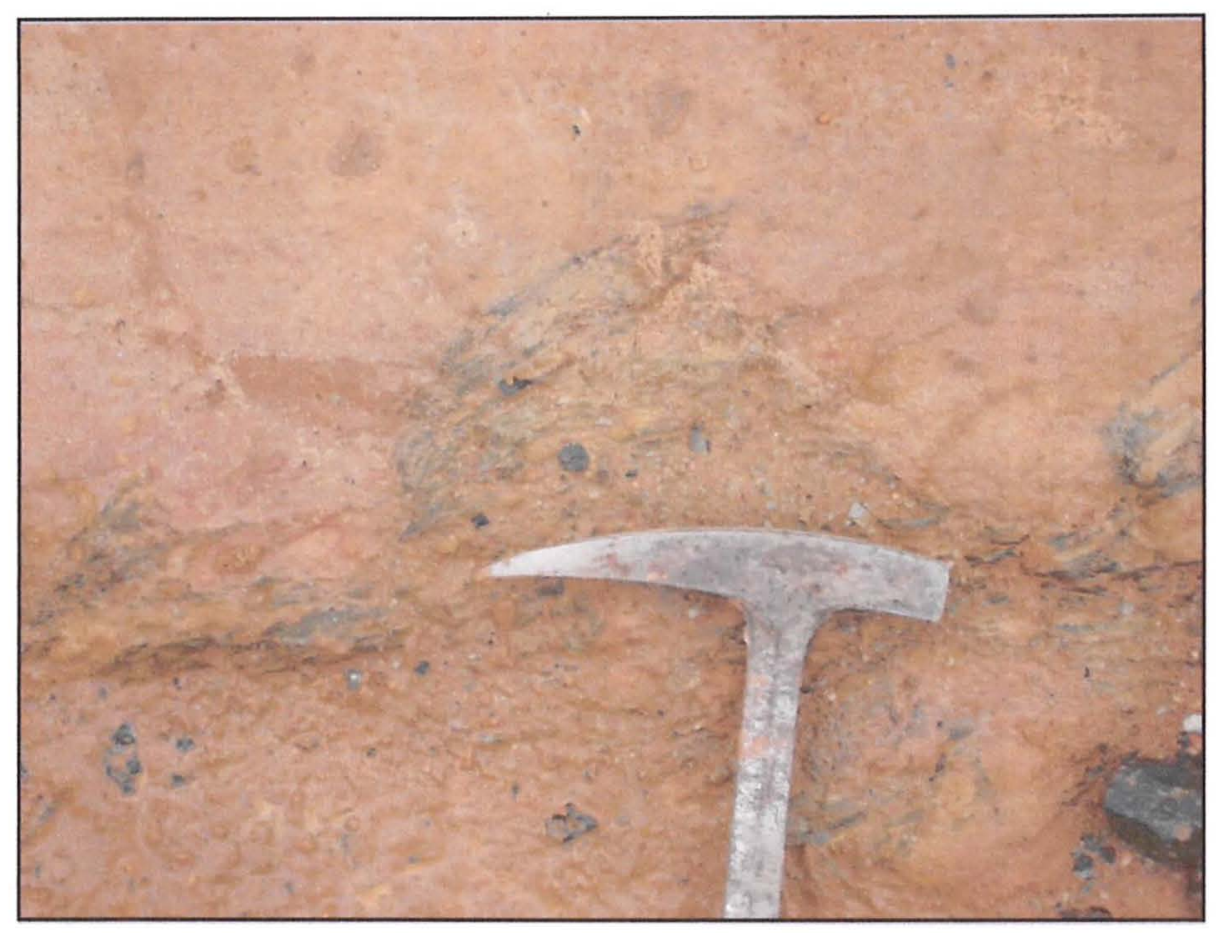

Figura 63. Porção pelítica deformada por sobrecarga ou sismo, configurando um diápiro (flame).

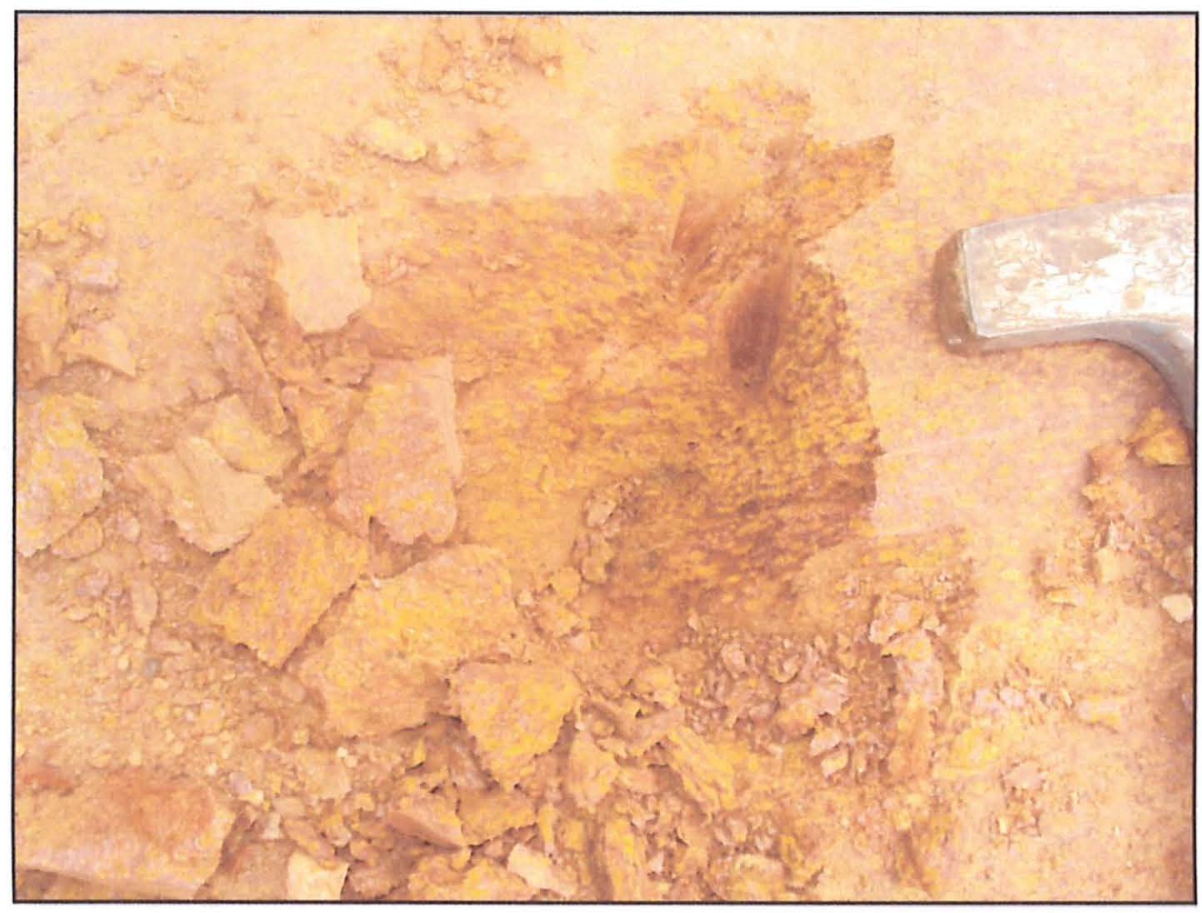

Figura 64. Intercalação de rocha vulcânica muito alterada entre os sedimentos da $\mathrm{Fm}$. Iporanga. As porçöes mais alaranjadas são prováveis amígdalas e vesículas. $O$ grau de alteração impossibilitou melhores descrições. 
As rochas da Formação Iporanga têm sido interpretadas por diversos autores como originadas em variados ambientes discordantes, tais como depósitos glaciogênicos (tills por causa de seus conglomerados), molassas,e turbiditos distais, conforme indicado por Faleiros (2000). Uma das interpretações mais plausíveis, pelo menos para a porção aflorante na Folha Capão Bonito, seria a de Pires (1988), que sugere um ambiente de turbiditos canalizados.

\subsubsection{D - Grupo Votuverava}

O Grupo Votuverava configura a faixa de rochas metassedimentares mais meridional dão Supergrupo Açungui na Folha Capão Bonito. Ele se encontra imediatamente a sul da Formação Iporanga, e se estende por toda a área de estudo paralelamente às outras litologias metassedimentares. Este grupo de rochas serve também de encaixante para o maior corpo granítico da região, conhecido por Batólito dos Agudos Grandes.

A área de afloramento do Grupo Votuverava pode ser observada conforme a figura 65 , na página seguinte. Este agrupamento rochoso é formalmente composto das Formações Ribeirão das Pedras, Piririca e Nhunguara. Este trabalho possibilitou ainda a individualização de mais uma unidade muito provavelmente perteaqui atribuída ao Grupo Votuverava, informalmente denominada de Formação Guapiara. Esta Formação aguarda a devida formalização com os trabalhos definitivos de mapeamento da Folha Capão Bonito pela CPRM - SUREG -SP e é, portanto, apenas uma sugestão pelo momento. 


\section{AFLORAMENTOS - GRUPO VOTUVERAVA}

Fig. 65

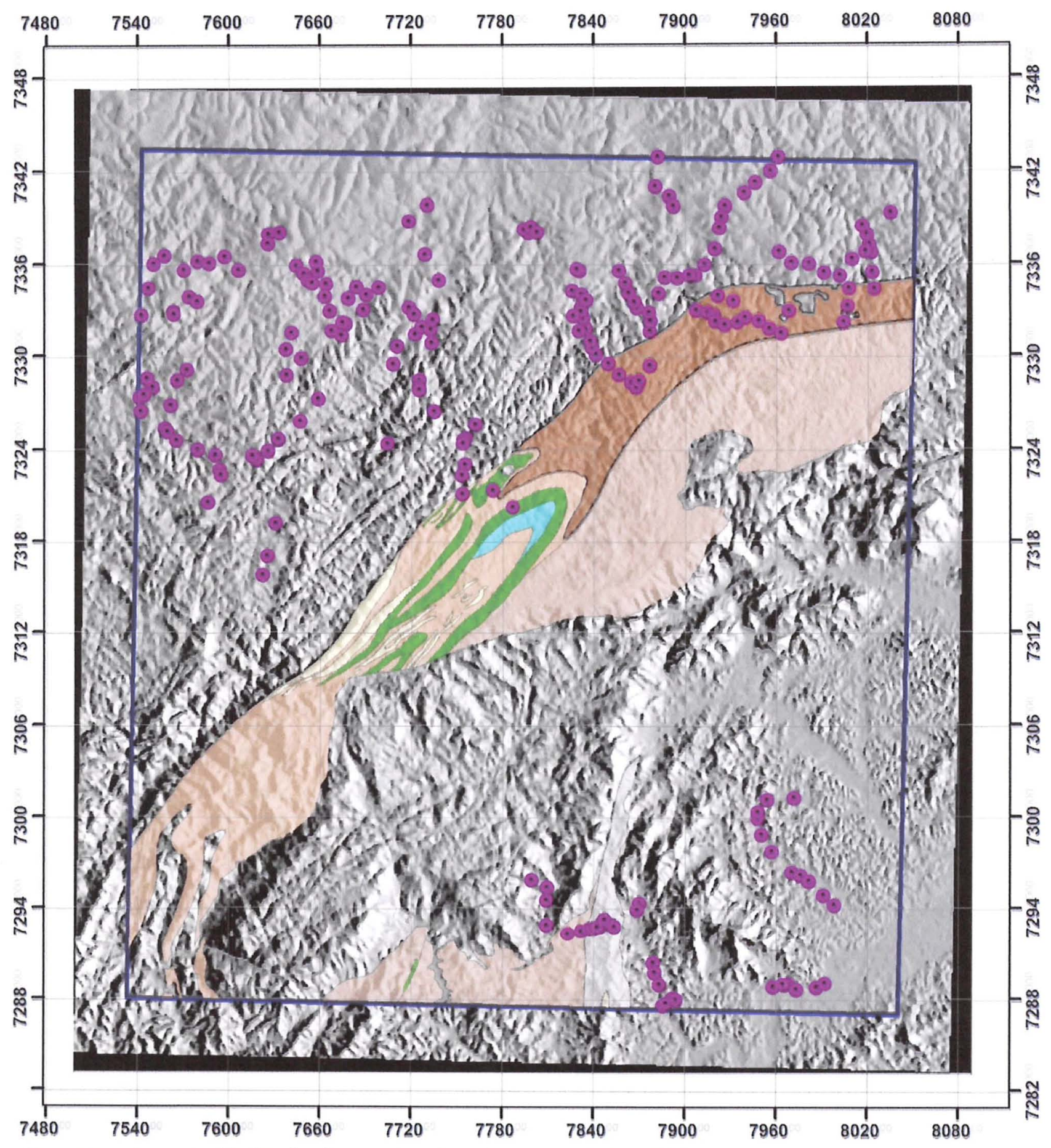

Supergrupo Açungui e Pontos de afloramento sobre relevo sombreado SRTM

\section{Litologias \\ Grupo Votuverava}

Fm. Ribeirão das Pedras

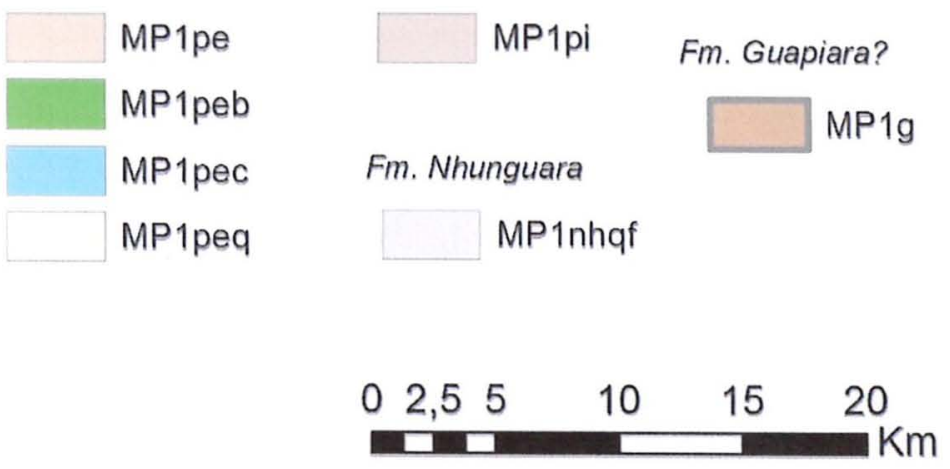

Localização da área na Folha Capão Bonit

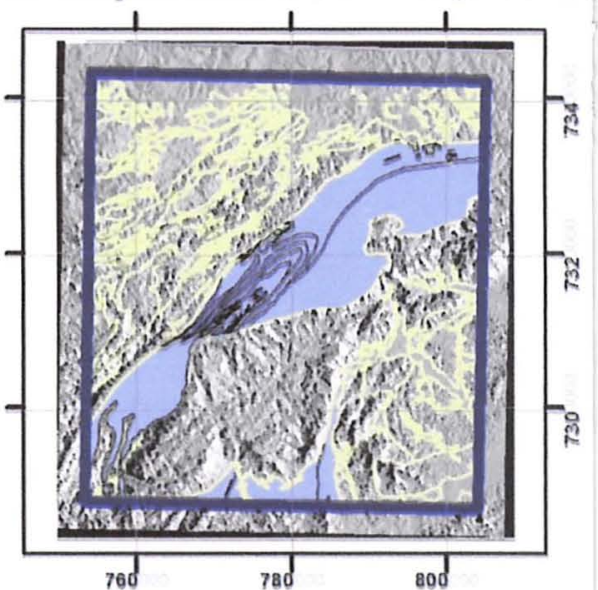


A região de afloramento do Grupo Votuverava se encontra dentro do Continuum Ecológico de Paranapiacaba. Foi uma das regiões que, infelizmente, careceram de pontos de caminhamento neste trabalho geológico.

Apesar da maioria das unidades não serem contempladas pelos caminhamentos geológicos realizados neste trabalho, foi possível, pelo menos para a porção extremo $\mathrm{NE}$, individualizar uma faixa de sedimentos rítmicos diferentes das outras rochas do Grupo Votuverava, aos quais aqui denominam-se informalmente como Formação Guapiara.

Os sedimentos do Grupo Votuverava apresentam caráter clástico e vulcanoclástico, raramente com contribuição química, formando metagrauvacas. Esta unidade caracteriza-se pela estrutura antiformal da escala de dezenas de quilômetros, bem na porção central da folha.

Segundo os trabalhos de Faleiros et al. (2011), o Grupo Votuverava (ca. 1500 - $1400 \mathrm{Ma}$ ) faz parte do Terreno Apiaí, um segmento do Cinturão Ribeira Meridional constituído por turbiditos distais com expressivo magmatismo básico representado por lentes concordantes de metabasito. Análises químicas de elementos traços realizadas nas rochas metabásicas desta unidade no trabalho supracitado sugerem que exista a coexistência de metabasitos com composições de basaltos toleíticos de arcos vulcânicos e basaltos de dorsais meso-oceânicas, sendo esta associação consistente com um ambiente de bacia retroarco.

A região mais a oeste do Grupo Votuverava foi bastante detalhada durante os levantamentos de campo deste trabalho. $\mathrm{O}$ fruto desta investigação pormenorizada foi a sugestão de individualização de uma nova unidade, informalmente denominada neste trabalho de Formação Guapiara. Esta Formação ocorre a leste da anticlinal central da folha, sendo composta essencialmente por um pacote de metassiltitos e ardósias, com padrão rítmico muito pronunciado e bastante homogêneo (figura 66). A estas rochas se associa grande quantidade de veios de quartzo em sua maioria decimétricos, com raras exceções de veios métricos (figura 67). Localmente pode ser desenvolvida uma crenulação (figura 68) discordante do acamamento sedimentar preservado, sendo interpretada como evidência de pelo menos um evento deformacional posterior ao metamorfismo o qual foi responsável por desenvolver uma foliação metamórfica paralela a $\mathrm{S}_{0}$. 


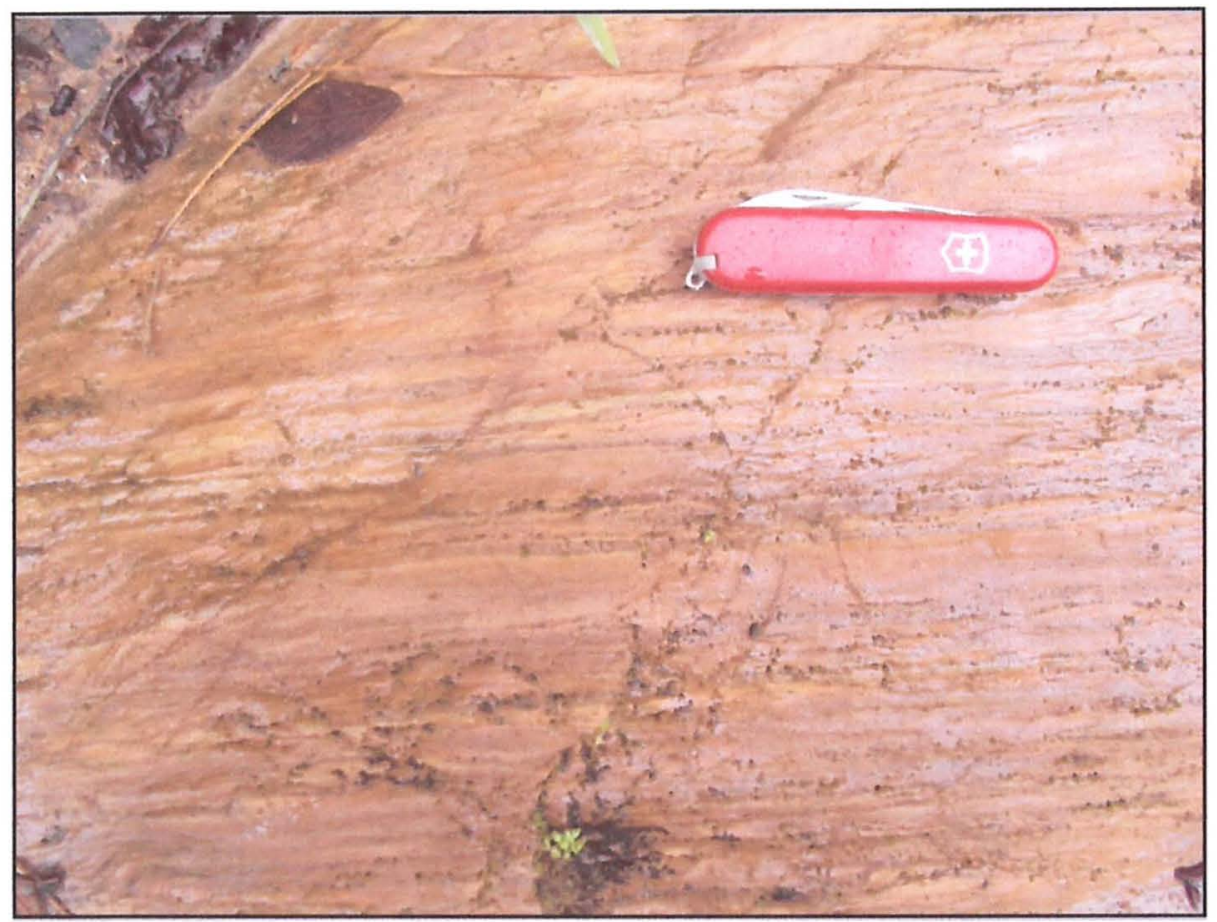

Figura 66 .Metassiltitos rítmicos da Formação Guapiara com a coloração característica em tons ocráceos.

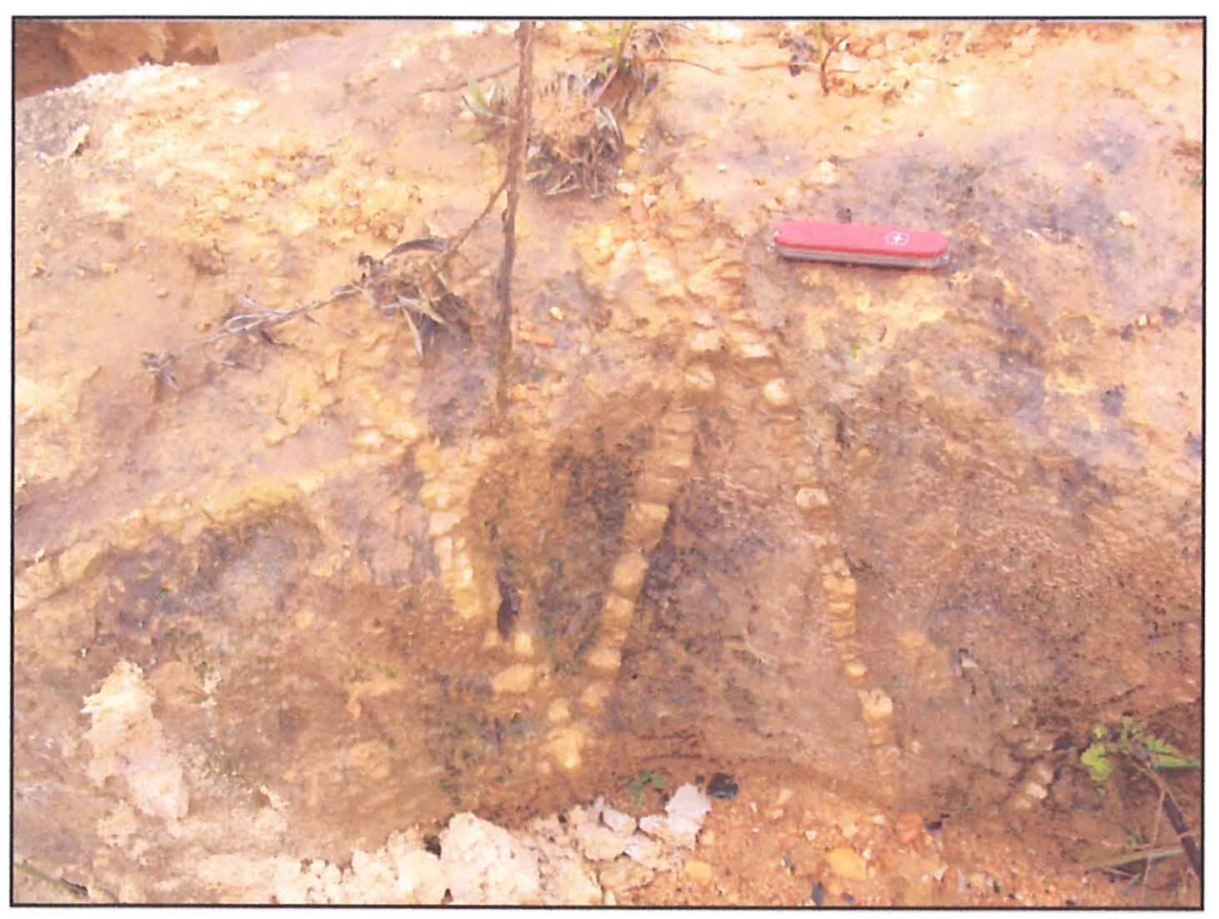

Figura 67. Veios de quartzo de espessura de até $5 \mathrm{~cm}$, muito abundantes entre os metassiltitos da Fm. Guapiara. 


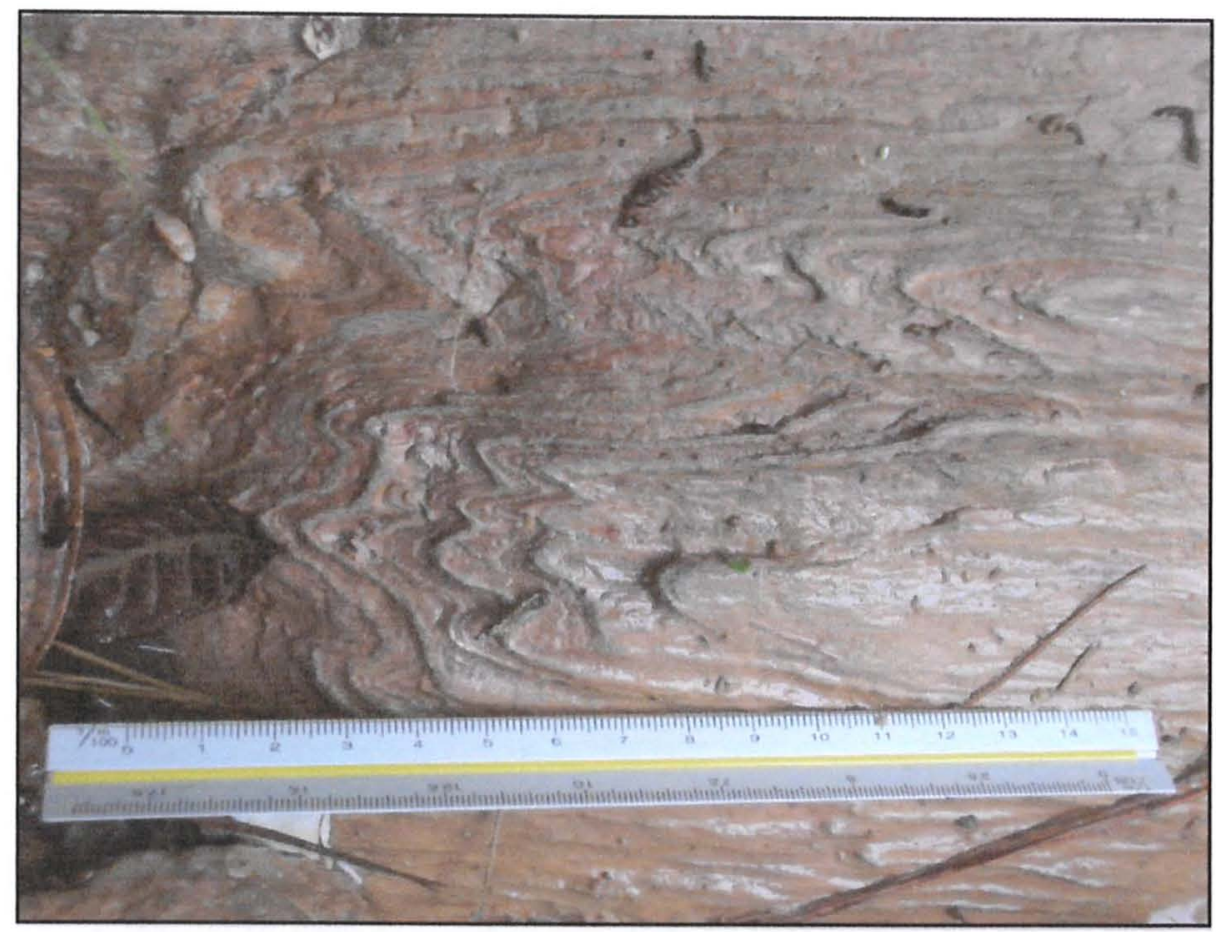

Figura 68. Desenvolvimento de crenulação nos metarritmitos da Fm.

Guapiara.

O Grupo Vouverava ocorre também na porção sul da folha Capão Bonito, a sul do Batólito de Agudos Grandes. Nesta região afloram basicamente duas Formações devidamente formalizadas por Perrotta (1996), conhecidas como Nhunguara e Piririca. Segundo a autora, a Formação Nhunguara é formada por (clorita)-sericita filito homogêneo a laminado com intercalações de filito carbonoso, filito carbonático, raros bancos de metarenito maciço e lentes de metabasitos, conforme se observa na figura 69 , um filito laminado com intercalações carbonosas escuras.

A Formação Piririca, por sua vez é predominantemente formada por filito carbonoso metavulcanossedimentar com intercalações de sericita-quartzo filito, bancos de metamarga bandada e filito carbonático e espessas lentes de metabasitos

O Grupo Votuverava representa por excelência a sedimentação vulcanoclástica do Supergrupo Açungui, sendo interpretado como uma sedimentação mesoproterozóica de turbiditos distais com contribuições vulcânicas em ambiente de colisão de placas oceânicas. 


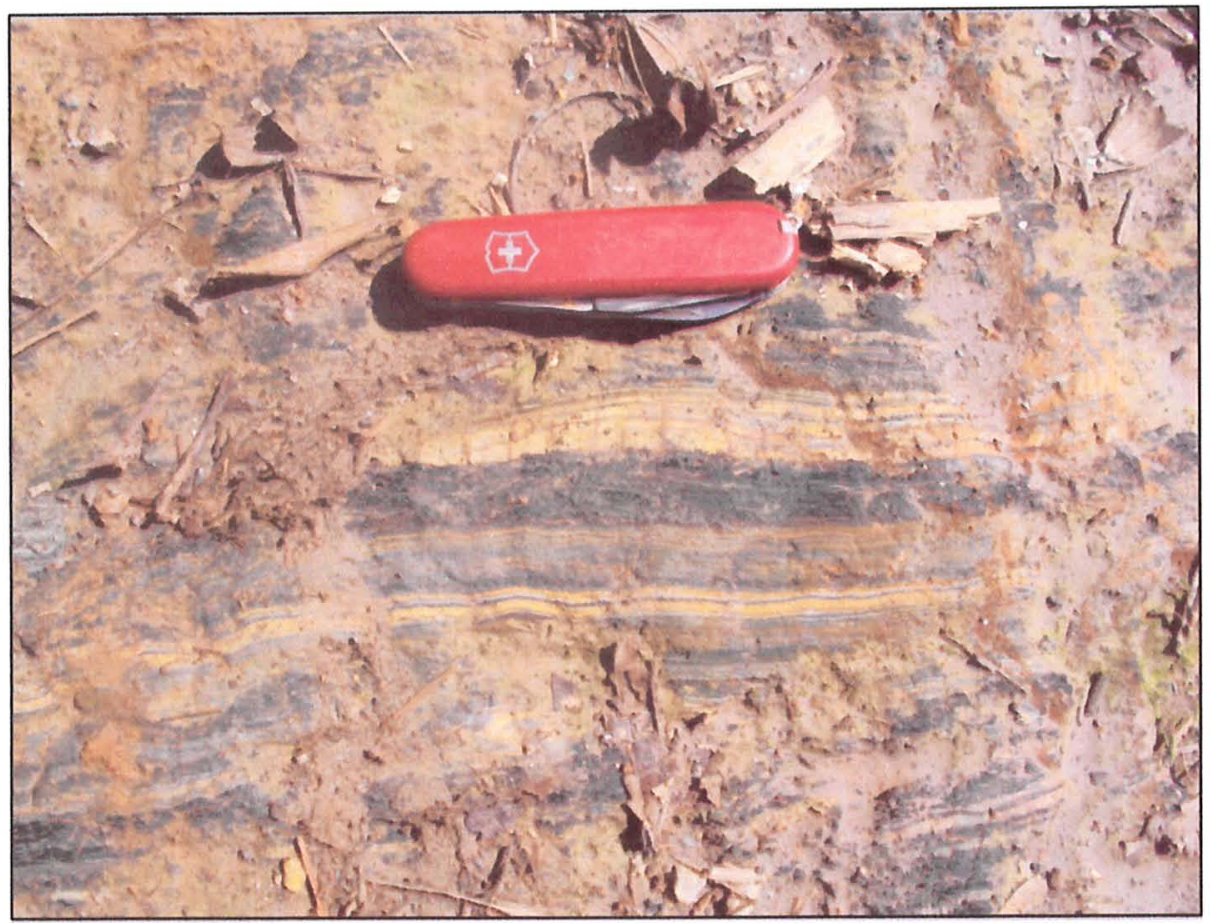

Figura 69. Metassiltitos finamente laminados com porções ricas em matéria orgânica (carbonosas), por vezes grafitosos, típicos da Fm. Nhunguara.

\subsubsection{3 - Granitos Ediacaranos}

Toda a extensão da Faixa de Dobramentos Ribeira é caracterizada pela presença de extensos corpos de rochas metassedimentares e metaígneas (no caso das unidades vulcânicas e de ortognaisses), as quais são interpretadas como uma aglutinação tectônica em ambiente transpressional durante a amalgamação do Supercontinente Gondwana.

A fase tardia deste importante evento tectônico foi responsável pela geração de diversos corpos intrusivos ácidos, ao final do Neoproterozóico. Estes granitos se caracterizam por sua ampla distribuição ao longo de toda a Faixa Ribeira, os mais antigos se dispondo de maneira concordante às zonas de cisalhamento regionais $\mathrm{e}$ adotando, pela movimentação ainda ocorrente à época de sua intrusão, um formato sigmoidal ou ocelar, com forte foliação de borda de corpo e desenvolvendo, em muitos casos, auréolas de metamorfismo de contato.

Corpos mais jovens são em sua maioria menos extensos e apresentam-se em intrusões arredondadas, com foliações de borda de corpo menos pronunciadas, sendo associados às fases pós-cinemáticas da Faixa Ribeira.

Na área de estudo, ocorrem conforme o apresentado na figura 70 a seguir: 
Fig. 70

\section{AFLORAMENTOS - GRANITOS EDIACARANOS}

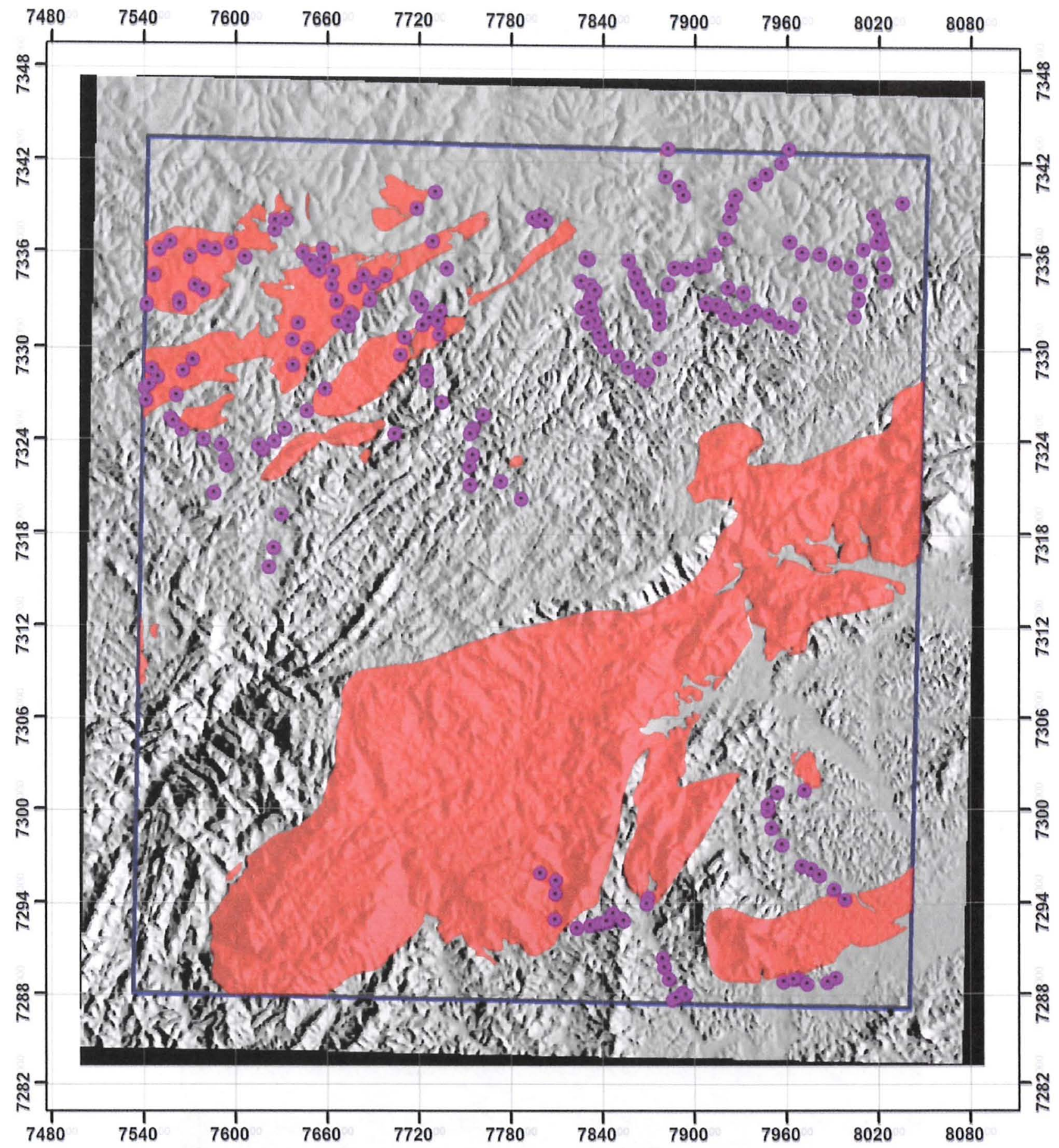

Granitos Ediacaranos Pontos de afloramento sobre relevo sombreado SRTM

\section{Litologias}

\section{NP3_gamma}

Granitos Ediacaranos Indiferenciados

Folha Capão Bonito

- Caminhamento

$\begin{array}{lllll}0 & 2,5 & 5 & 10 & 15\end{array}$

Localização da área na Folha Capão Bonito

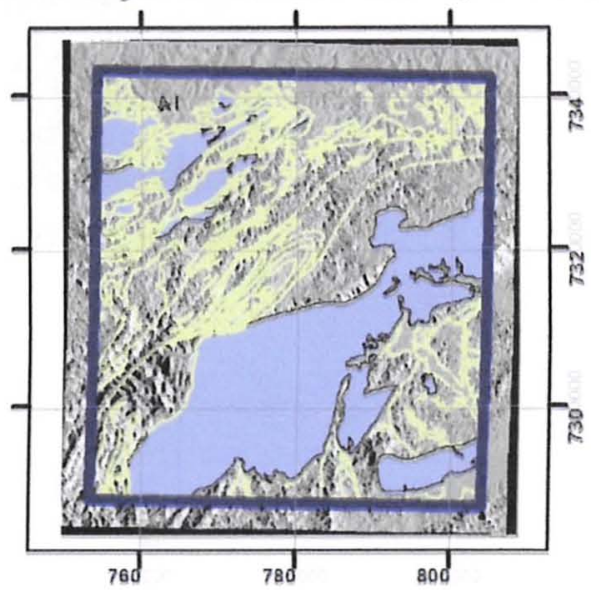


De maneira geral estes granitos apresentam textura inequigranular fanerítica média a grossa, na maioria das vezes apresentando megacristais e fenocristais, desenvolvendo textura porfirítica. Em geral, os megacristais são de plagioclásio ou feldspato potássico, dependendo da afinidade química de cada corpo granítico. Em geral, apresentam foliações de corpo de borda, com textura de cominuição de cristais, típicas de esforço. Conforme se caminha para o interior dos corpos intrusivos, esta foliação tende a ser substituída por foliação de fluxo, evidenciada pelo imbricamento dos cristais e fenocristais, com a ausência de deformação cristalina.

A composição dos corpos graníticos ocorrentes na área é, bastante variada, podendo ocorrer desde sieno granitos (no caso do Granito Capão Bonito, reconhecido por suas qualidades ornamentais) até monzo granitos e granodioritos, mais ricos em plagioclásio.

As fotografias a seguir mostram algumas variedades de granitos encontradas na área da Folha Capão Bonito:

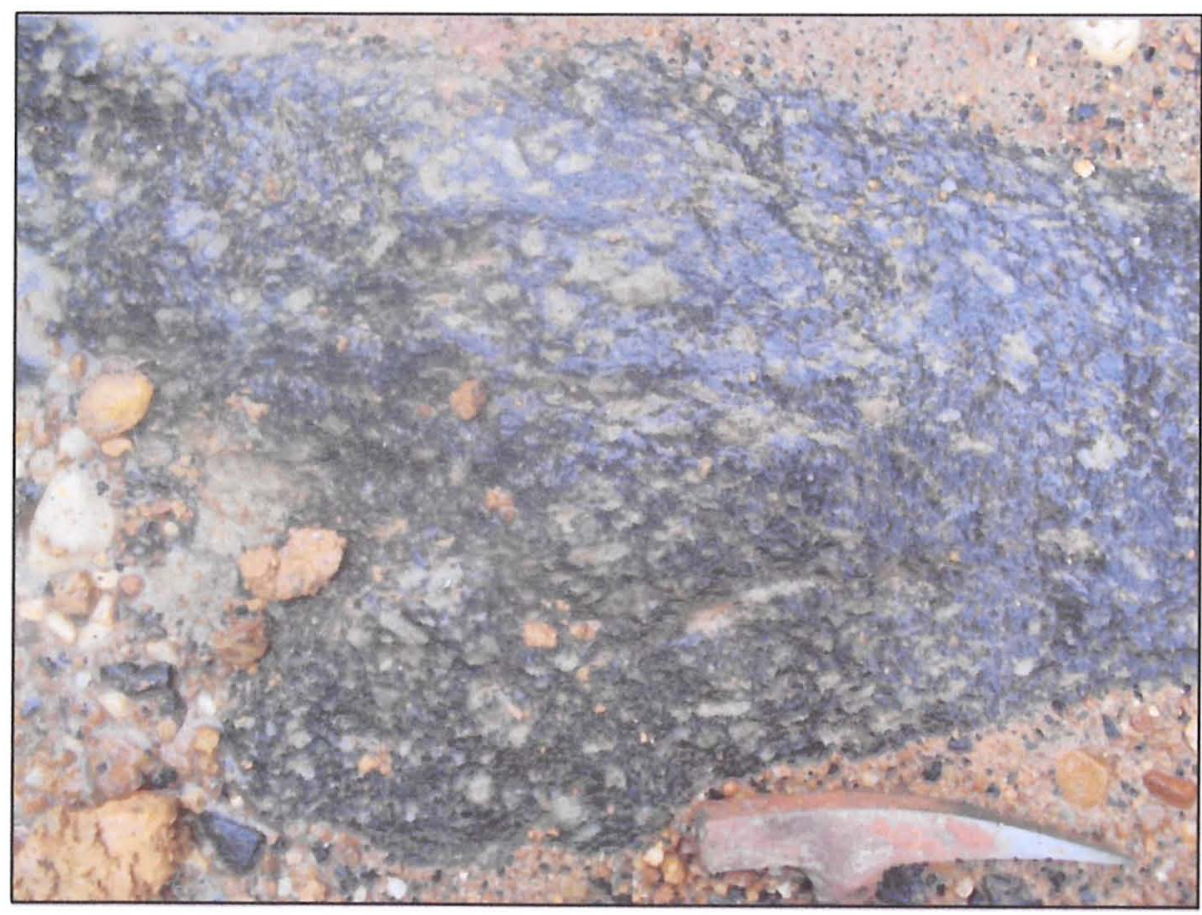

Figura 71. Monzogranito porfirítico ocorrente no corpo intrusivo no extremo sudeste da folha Capão Bonito. 


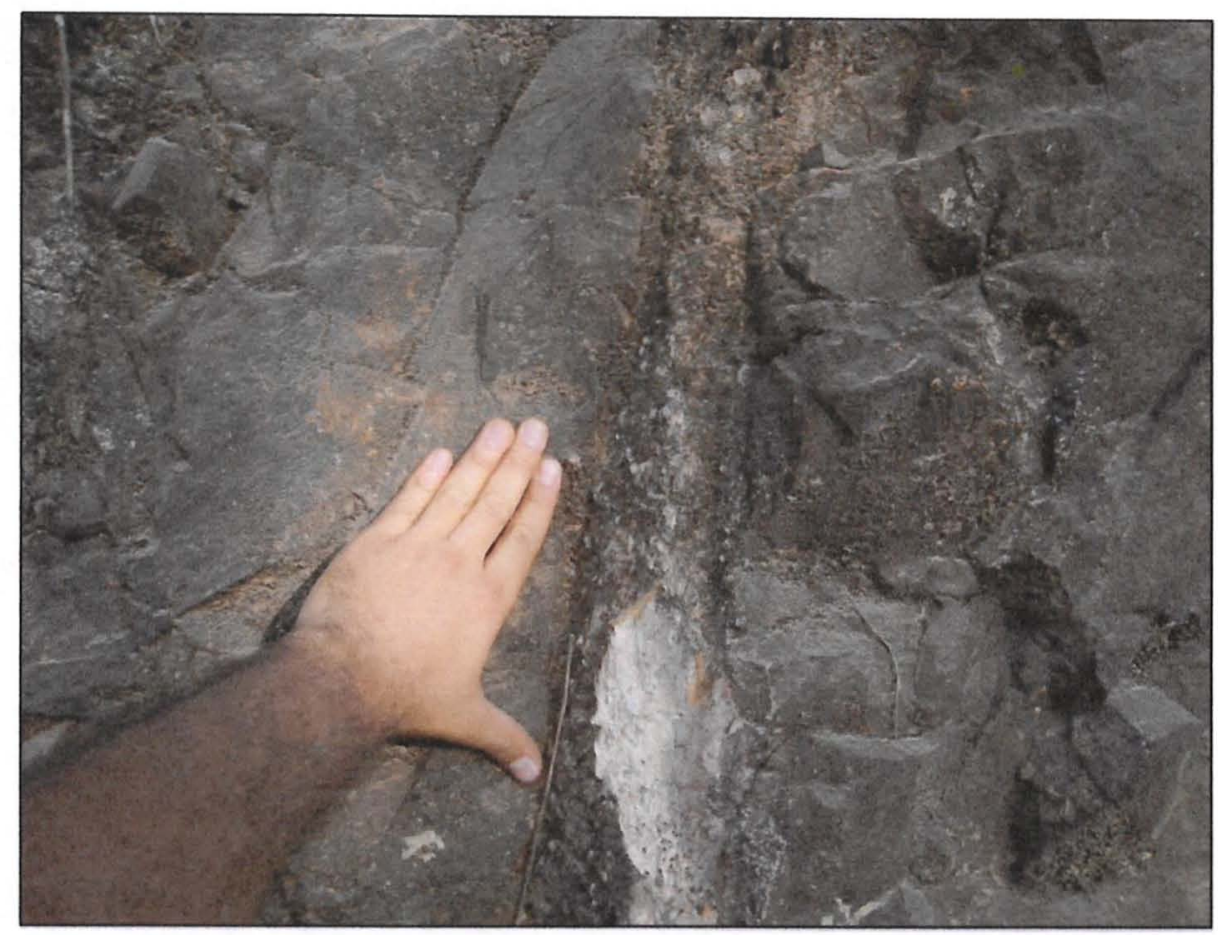

Figura 72. Apófise granítica intrudindo metassedimentos rudáceos da Fm. Água Clara, porção NW da folha Capão Bonito.

A região NW da folha conta com um maciço granítico de grande importância econômica para o município de Capão Bonito, um plúton de sienogranito grosso extensamente explorado para rocha ornamental, conhecido como granito Vermelho Capão. A figura 73, retirada de Bolonini \& Godoy, 2012, fornece um excelente panorama das variações texturais ocorrentes neste corpo de rocha.

Os corpos graníticos intrusivos na faixa ribeira são de extrema importância econômica para a região sudeste, sendo importantes fontes de agregados para a construção civil dos grandes centros urbanos do país (São Paulo, Rio de Janeiro e Curitiba), além de serem fontes de rochas ornamentais e de revestimento, destacando-se a região do estado do Espírito Santo.

Em São Paulo, os granitos mais explorados e reconhecidos estão inseridos no contexto da Faixa Ribeira, sendo eles o Granito Capão Bonito, o Granito de Itu e o Granito Cinza Mauá os mais conhecidos pela indústria de rochas ornamentais. 


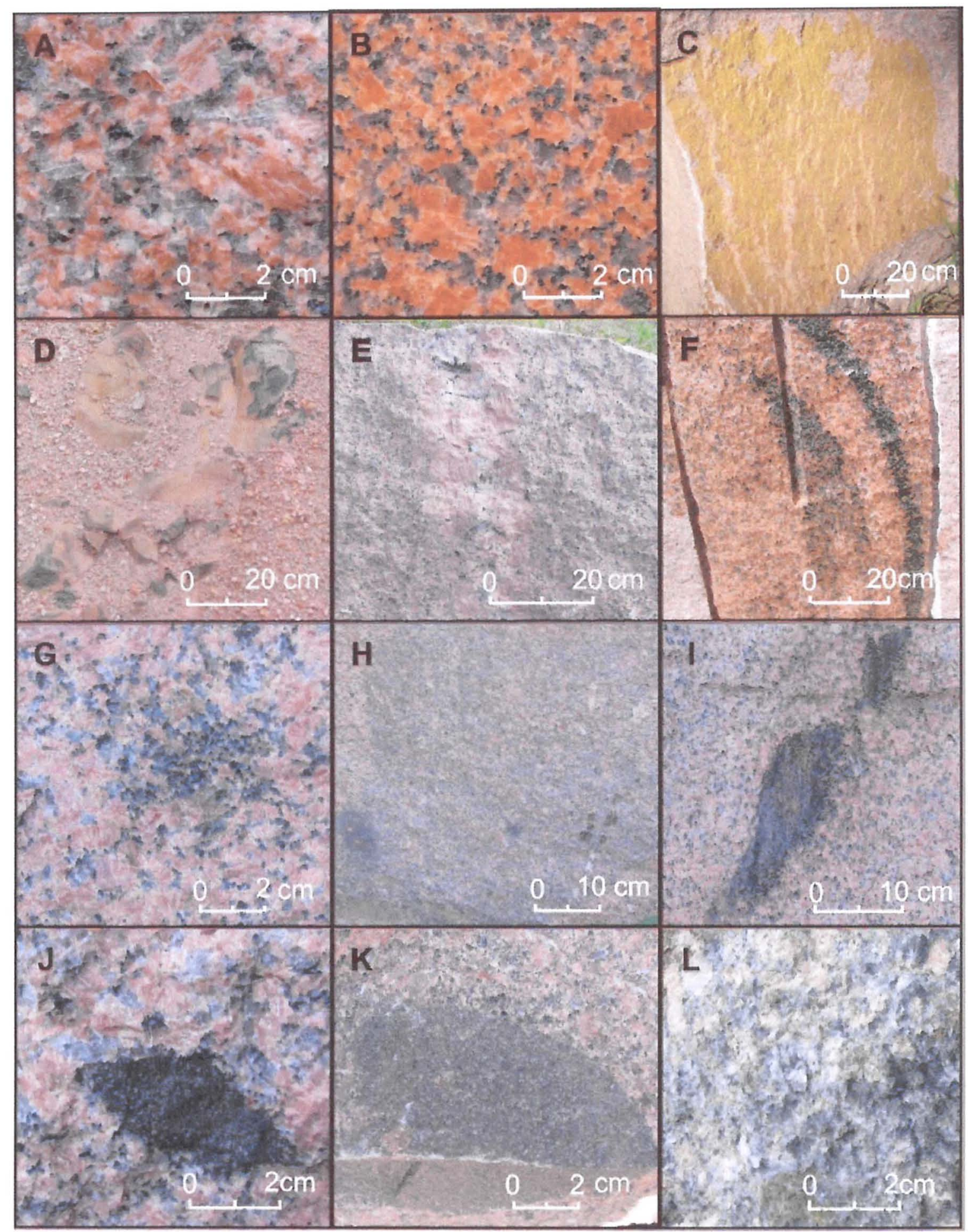

Figura 73. Variações texturais encontradas no Granito Capão Bonito, retirado de Bolonini \& Godoy, 2012. A e B) Homogeneidade textural e composicional. C) Planos de falha com minerais secundários. D) Diques de Diabásio. E) Veios pegmatóides. F e G) Schlieren. H) Mistura magmática. I e J) Enclaves máficos. $\mathrm{Ke} \mathrm{L}$ ) Xenólitos de outros granitos. 


\subsubsection{4 - Cobertura Sedimentar Paleozóica}

A região da cidade de Capão Bonito se situa na borda da Bacia Sedimentar do Paraná. A unidade predominante na região é a Formação Lagoa Azul, do Grupo Itararé. Este agrupamento de rochas sedimentares foi considerado por Milani et al. (2007) como pertencente à Supersequência Gondwana I. A área de ocorrência destas rochas está restrita à porção norte da Folha Capão Bonito, conforme pode ser observar na figura 74 .

Na região de Capão Bonito, assentam-se sobre as rochas proterozóicas, extensos pacotes de lamitos e siltitos finamente laminados, intercalados com lâminas milimétricas de granulação silto-arenosa. Estas rochas estão posicionadas de maneira sub-horizontal, com leve caimento para Oeste.

Esta associação litológica é de idade Permo-Carbonífera, e perfaz o maior registro sedimentar contínuo de toda a sinéclise, podendo chegar aos $2500 \mathrm{~m}$ de espessura de sedimentos. Segundo Milani et al. (2007), a espessura deste pacote se deve ao enorme volume de sedimento gerado pelos intensos processos de denudação do relevo favorecidos por geleiras, as quais se desenvolveram quando o Supercontinente Gondwana se postava em latitudes mais elevadas. 
Fig. 74

AFLORAMENTOS - GRUPO ITARARÉ

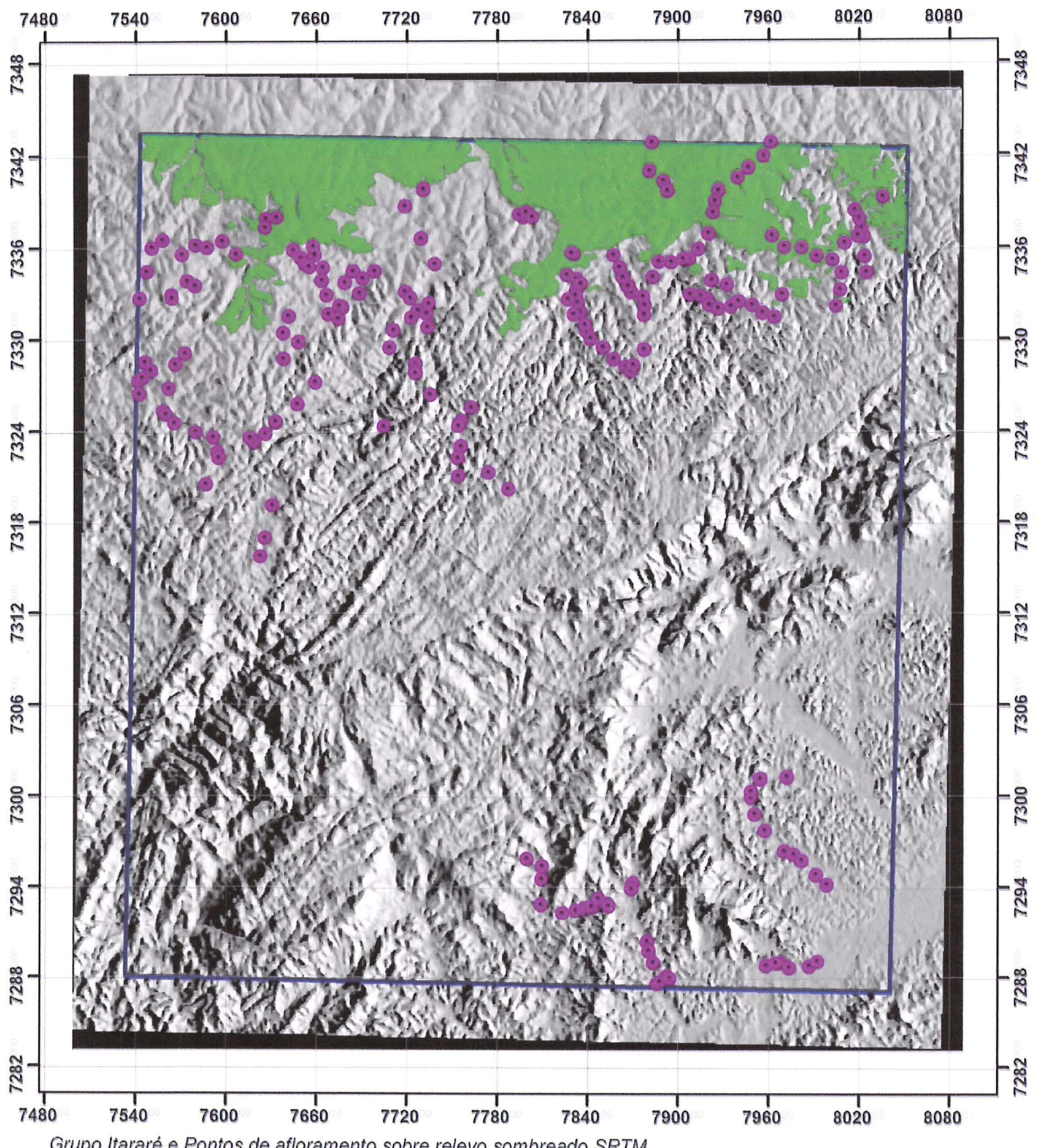

Litologias

C2P1la

Formação lagoa Azul - Grupo ltararé

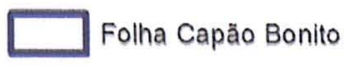

- Caminhamento

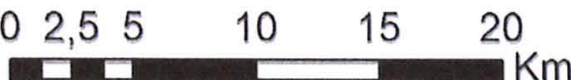

Localizaçầo da área na Folha Capão Bonitc

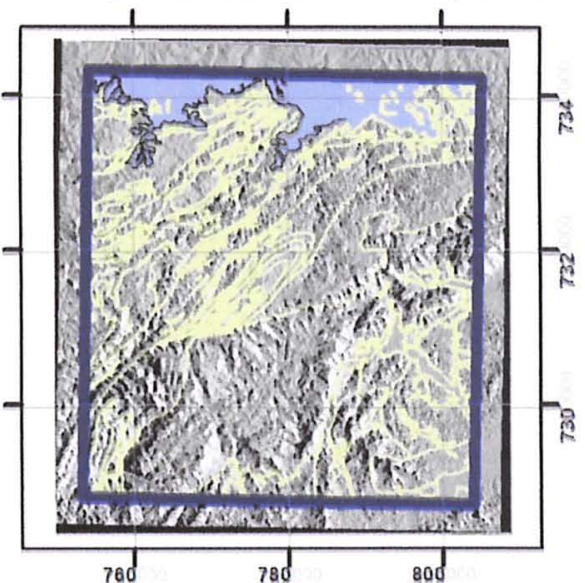


Estes sedimentos têm sido interpretados como uma sequência deposicional associada à sedimentação lacustre em um ambiente glacial, ideia corroborada por diversas ocorrências de diamictitos (tillitos), ritmitos (varvitos), pavimentos estriados, clastos caídos e ausência de fósseis, ocorrências estas descritas em diversas outras partes da borda leste da Bacia do Paraná.

$\mathrm{Na}$ localidade, não foram encontradas evidências de sedimentação glacial, mas sem dúvida a semelhança com outros litotipos já consagrados como de influência glaciogênica (e.g. os Varvitos de Itu), é grande, conforme pode ser observado na figura 75 .

São siltitos de coloração cinza escura, apresentando forte empastilhamento, e apesar da grande quantidade de matéria orgânica evidenciada por sua coloração escura, apresenta-se afossilifero. Nestas rochas, as únicas estruturas sedimentares ocorrentes são a laminação que intercala porções silto-argilosas predominantes com lâminas milimétricas de material siltoso a arenoso fino, raramente com estruturas heterolíticas submilimétricas.

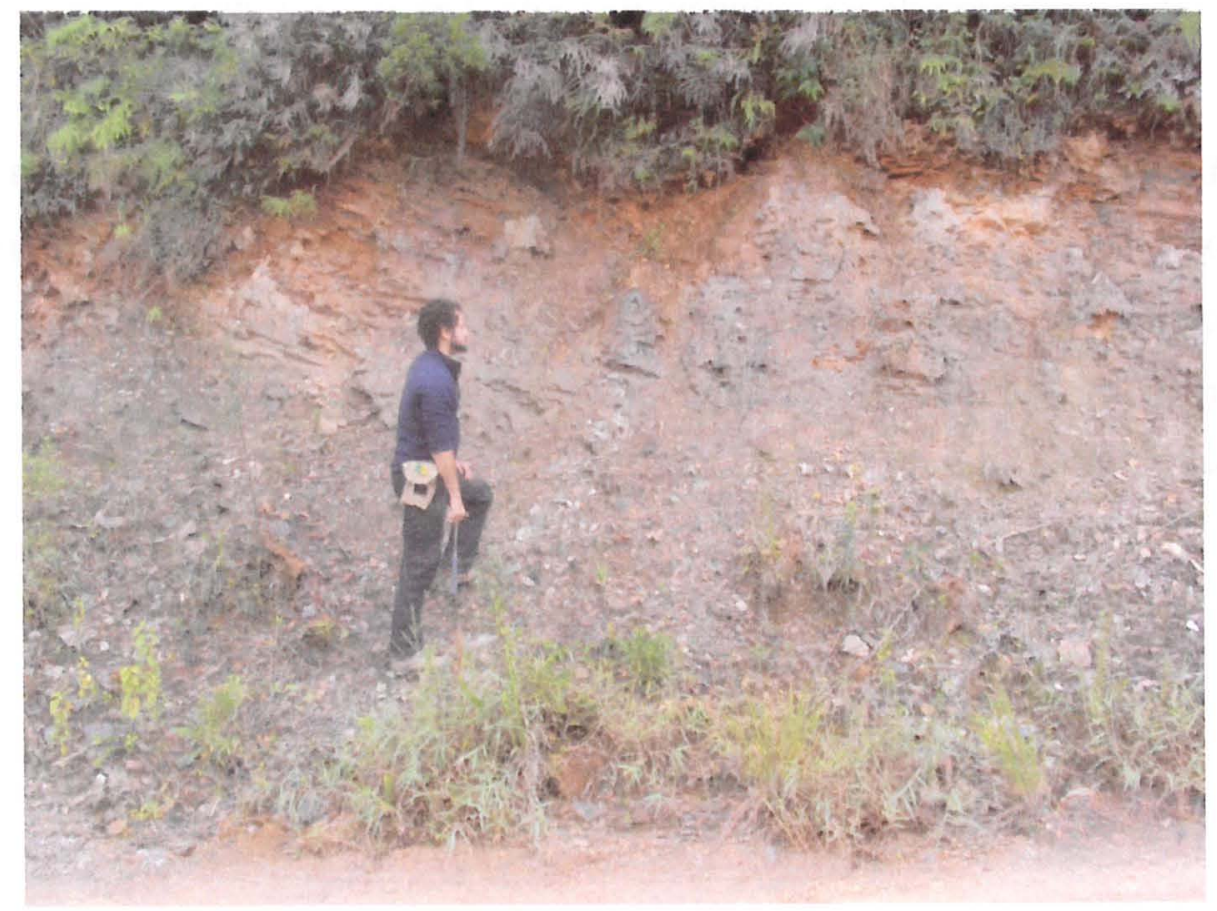

Figura 75.. Afloramento dos siltitos da Fm. Lagoa Azul, do Grupo Itararé, em região próxima do contato discordante com os metamorfitos do Supergrupo Açungui, na porção Norte da Folha Capão Bonito. 


\subsubsection{5 - Cobertura Sedimentar Terciária - Gráben de 7 Barras}

O extremo sudeste da folha Capão Bonito abriga a Depressão Baixo Ribeira, caracterizada por um relevo muito abatido, em contrapartida ao seu limite norte, a Serra de Paranapiacaba. É marcado pela presença de morros arredondados em 'meia laranja', todos de tamanho muito similar e com espaçamento entre morros constante. Nesta região, destaca-se a presença de extensas planícies aluvionares recentes, além de depósitos sedimentares terciários em uma bacia tipo Graben alongada na direção NE-SW, o Graben de Sete Barras. Segundo Riccomini (1989) e Melo (1989), esta pequena bacia sedimentar associa-se à tafrogenia do Rift Continental do Sudeste do Brasil, sendo correlata às outras bacias Cenozoicas da borda atlântica, tais como as Bacias de São Paulo, Curitiba, Volta Redonda e Taubaté.

A área de ocorrência destas rochas pode ser melhor observada na figura 76 , bem no extremo sudeste da folha Capão Bonito. Apesar de neste mapa não serem individualizados os sedimentos inconsolidados quaternários daqueles terciários, nota-se um corpo mais largo de aluviões a sul, alongado na direção NE-SW. Esta região é parte integrante do Graben de Sete Barras. 
Fig. 76

\section{AFLORAMENTOS - SEDIMENTOS TERCIÁRIOS E HOLOCÊNICOS}

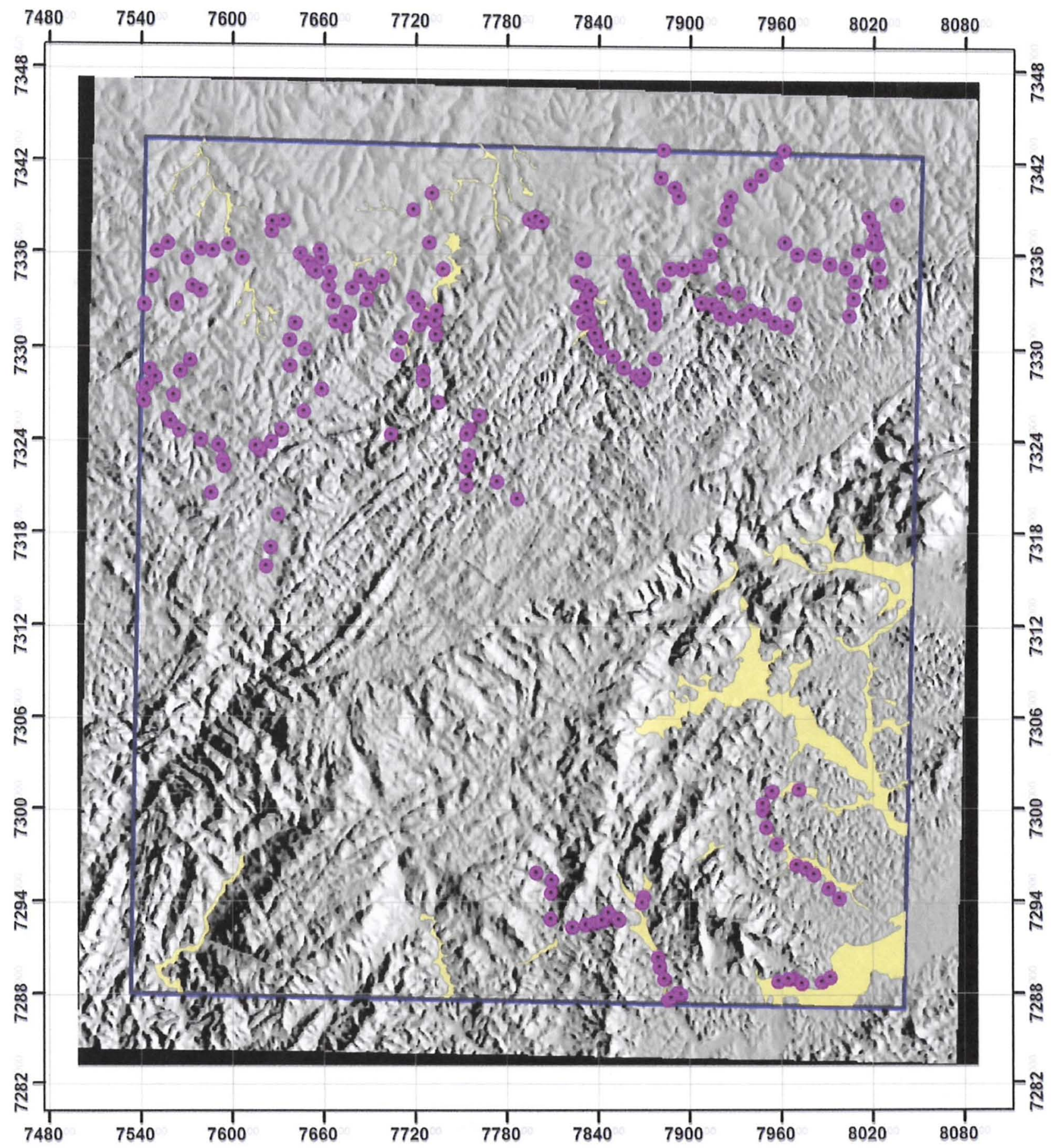

Coberturas Terciárias e Pontos de afloramento sobre relevo sombreado SRTM

Litologias

Coberturas Terciárias e aluviões Holocênicos

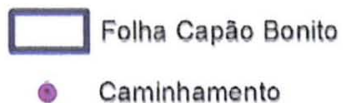

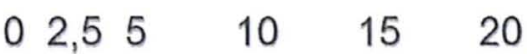
$\mathrm{Km}$

Localizaçào da área na Folha Capâo Bonito

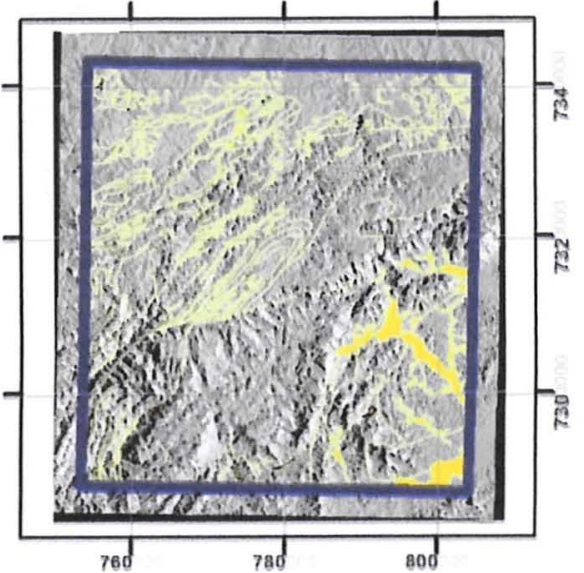


Litologicamente é composto por camadas ortoconglomeráticas, areias e depósitos de corrida de detritos, decorrentes da forte erosão nas bordas da depressão. $\mathrm{Na}$ região mais central do gráben, predominam lamas que, segundo Melo $(1989,1990)$, teriam sido depositadas em um paleolago central.

A seção tipo destas litologias, no entanto, não ocorre na área da folha Capão Bonito, mas um pouco a leste, na região da cidade de Sete Barras. Nesta localidade, foi possível observar uma exposição de paraconglomerados polimíticos com matriz de coloração avermelhada a arroxeada, mal selecionada e com baixo grau de arredondamento de seus clastos (figura77).

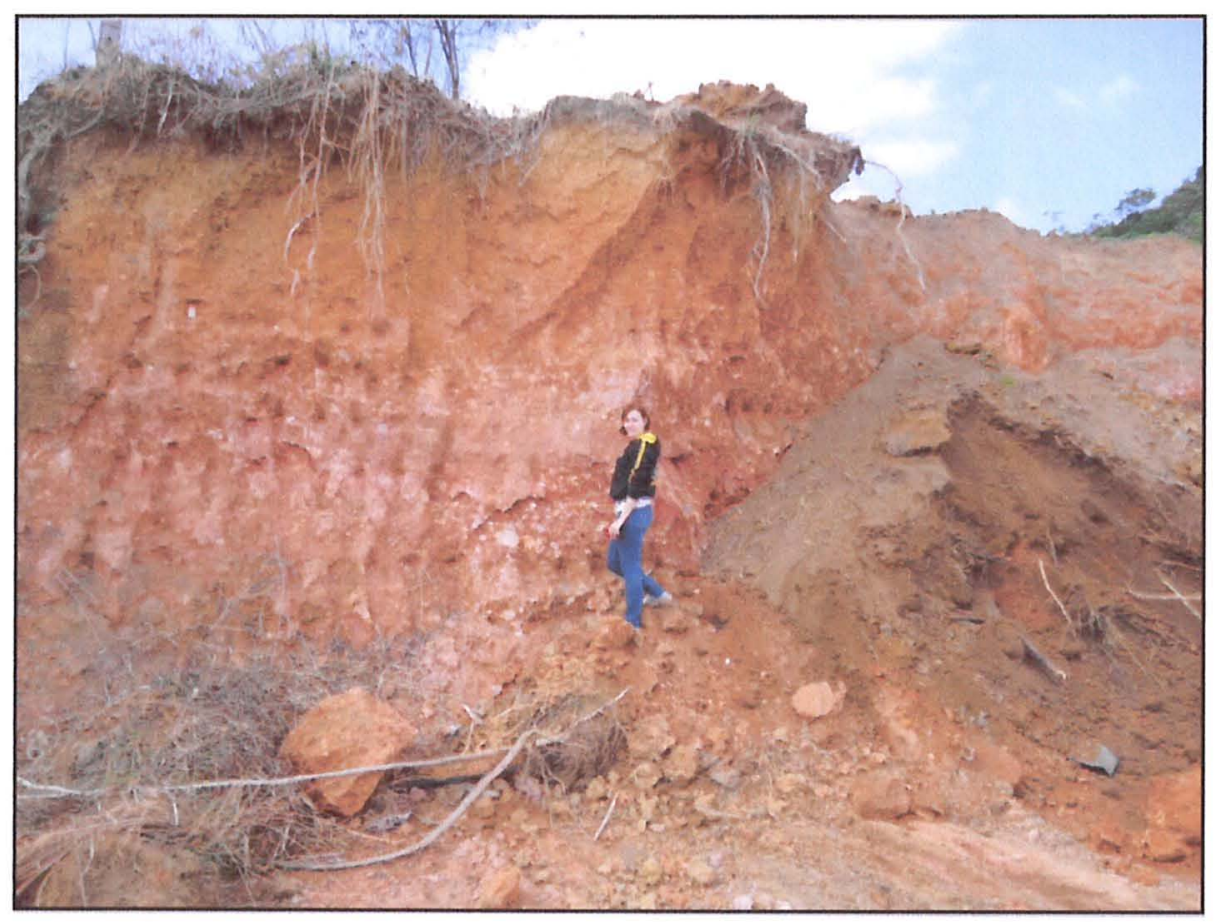

Figura 77. Afloramento - tipo dos paraconglomerados da Formação Sete Barras, em afloramento na cidade homônima.

Os clastos contidos nestas rochas são das mais variadas litologias, todas elas pertencentes à Faixa Ribeira, algumas passiveis de identificação, tais como os metarritmitos do Grupo Votuverava (figura 78), quartzitos e clastos de granitos ediacaranos (figura 79). 


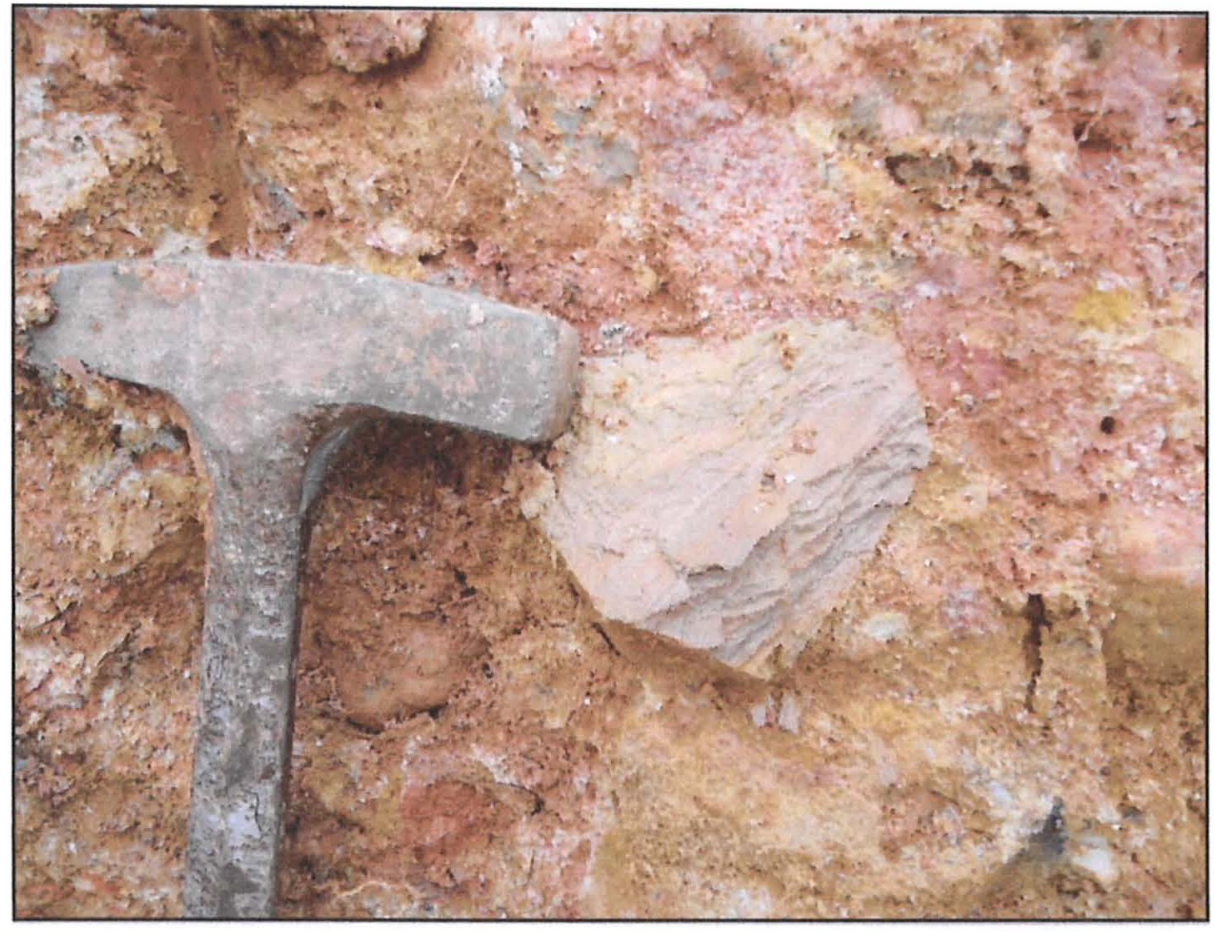

Figura 78. Clasto de metassiltito anguloso provavelmente proveniente do Grupo Votuverava.

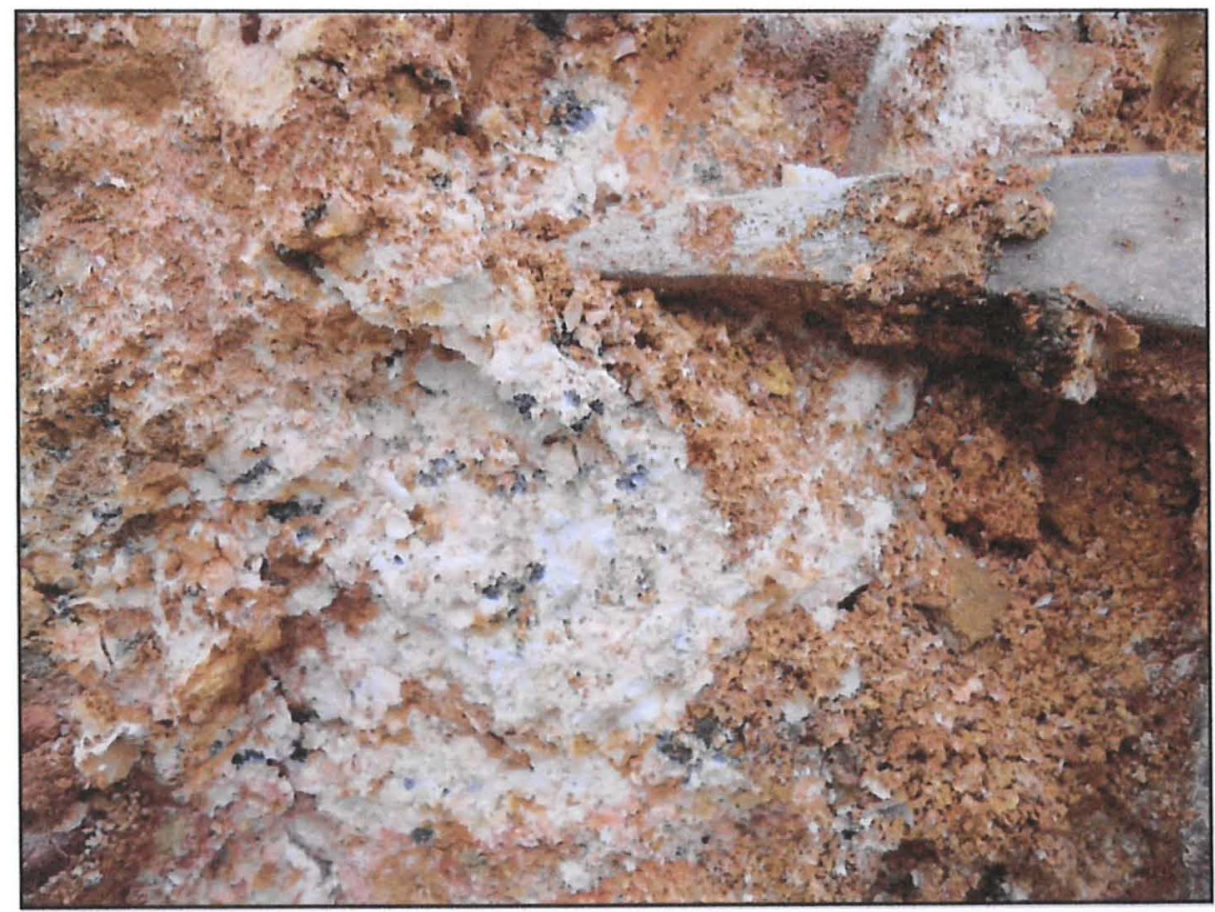

Figura 79. Clasto de rocha granítica bastante alterado para caulim, com minerais máficos ainda resistindo ao intemperismo. 
Foi encontrado neste afloramento, em meio ao pacote conglomerático, uma rocha que apresentava feições similares a lavas almofadadas (pillow-lavas), conforme o observado na figura 80 . O afloramento se encontra bastante alterado, o que sem dúvida pode levar a interpretações errôneas. Apesar disto, há algumas evidências que corroboram a ocorrência de um derrame subaquoso na região. São elas: 1. A cor de alteração das rochas bastante ocrácea é característica das rochas básicas ou alcalinas alteradas (formação de bauxitas). 2. A presença de bordas centimétricas com minerais argilosos claros, como se fossem as bordas de congelamento são típicas deste tipo de magmatismo. 3. A associação de diversos corpos de magmas alcalinos com o contexto do rifteamento do sudeste, a exemplo do ocorrente na região de Poços de Caldas, na região de Itatiaia, na Bacia de Taubaté e Volta Redonda com a ocorrência de derrames de ankaramitos (Riccomini 1989) e mesmo nas proximidades na área de estudo, com a intrusão carbonatítica de Cajati.

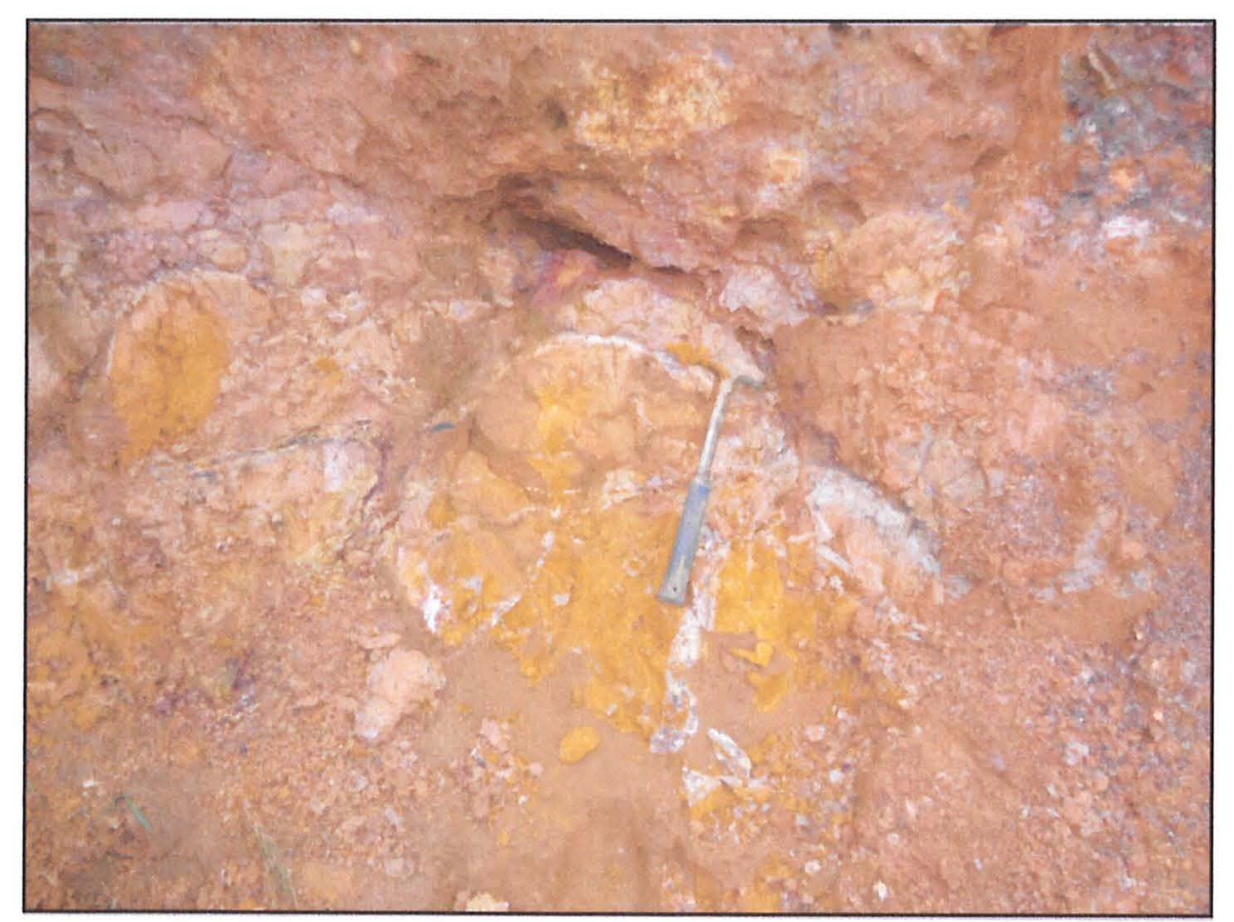

Figura 80. Suposta lava almofadada entre os sedimentos conglomeráticos do Graben de Sete Barras. Estrada Sete Barras - S. Miguel Arcanjo, logo após a saída da cidade de Sete Barras sentido $\mathrm{N}$. 
A confirmação desta hipótese, no entanto, depende de estudos mais aprofundados na região do Graben de Sete Barras, principalmente do estudo desta ocorrência sobre o ponto de vista da química mineral, o que infelizmente não cabia no escopo deste trabalho. Fica descrita, apesar disto, a ocorrência desta intrigante feição, de maneira a convidar àqueles que se sintam curiosos, a estudá-la de maneira mais pormenorizada.

Sotoposto a estas unidades, há o capeamento aluvionar atual, em processo de deposição em toda a planície de inundação do Ribeira de Iguape. São conglomerados finos a médios, areias conglomeráticas e lentes argilosas, com uma ampla ocorrência em toda a região. Na cidade de Eldorado, no extremo sul da folha Capão Bonito, foi possível observar em uma vala aberta para a instalação de tubulação de esgoto um interessante afloramento mostrando os depósitos de planície de inundação do Ribeira de Iguape em contato discordante com os metamorfitos do Supergrupo Açungui, conforme o demonstrado na figura 81.

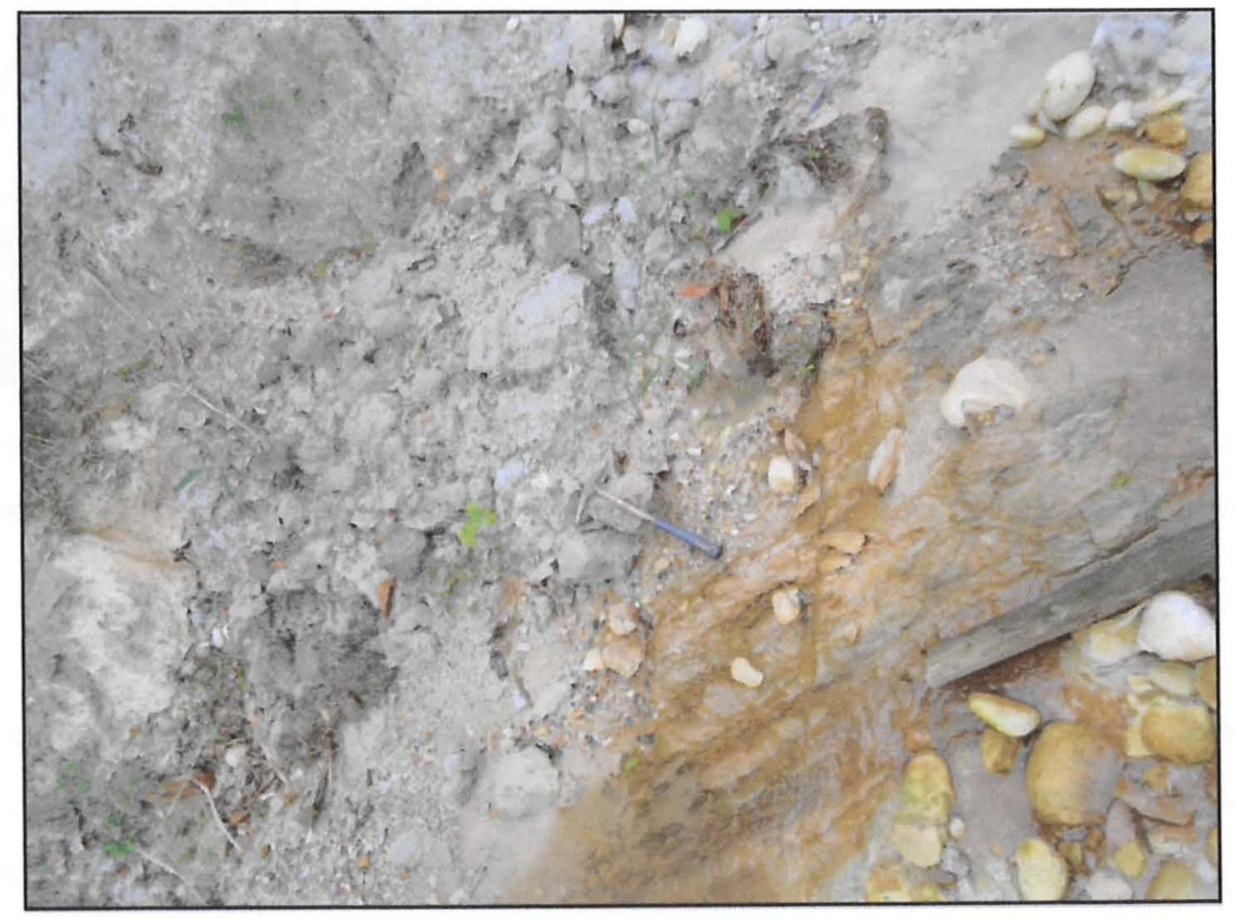

Figura 81. Lamas e areias conglomeráticas de cor cinza clara depositadas sobre o pavimento metamórfico amarronzado da Formação Nhunguara. Cidade de Eldorado. 
Esta foto (figura 82) foi tomada na região distal do depósito aluvionar associado ao rio Ribeira de Iguape, sendo fruto da sedimentação em episódios de enchentes, muito comuns na região. Estas inundações podem tomar proporções catastróficas para a população local, conforme o atestado pela figura 82 que mostra a marca da enchente do ano de 2011. Isto evidencia o poder deste rio, que acaba depositando, nas localidades mais distantes de sua calha, pacotes de lamas e areias típicos de rompimento de diques marginais de rios meandrantes.

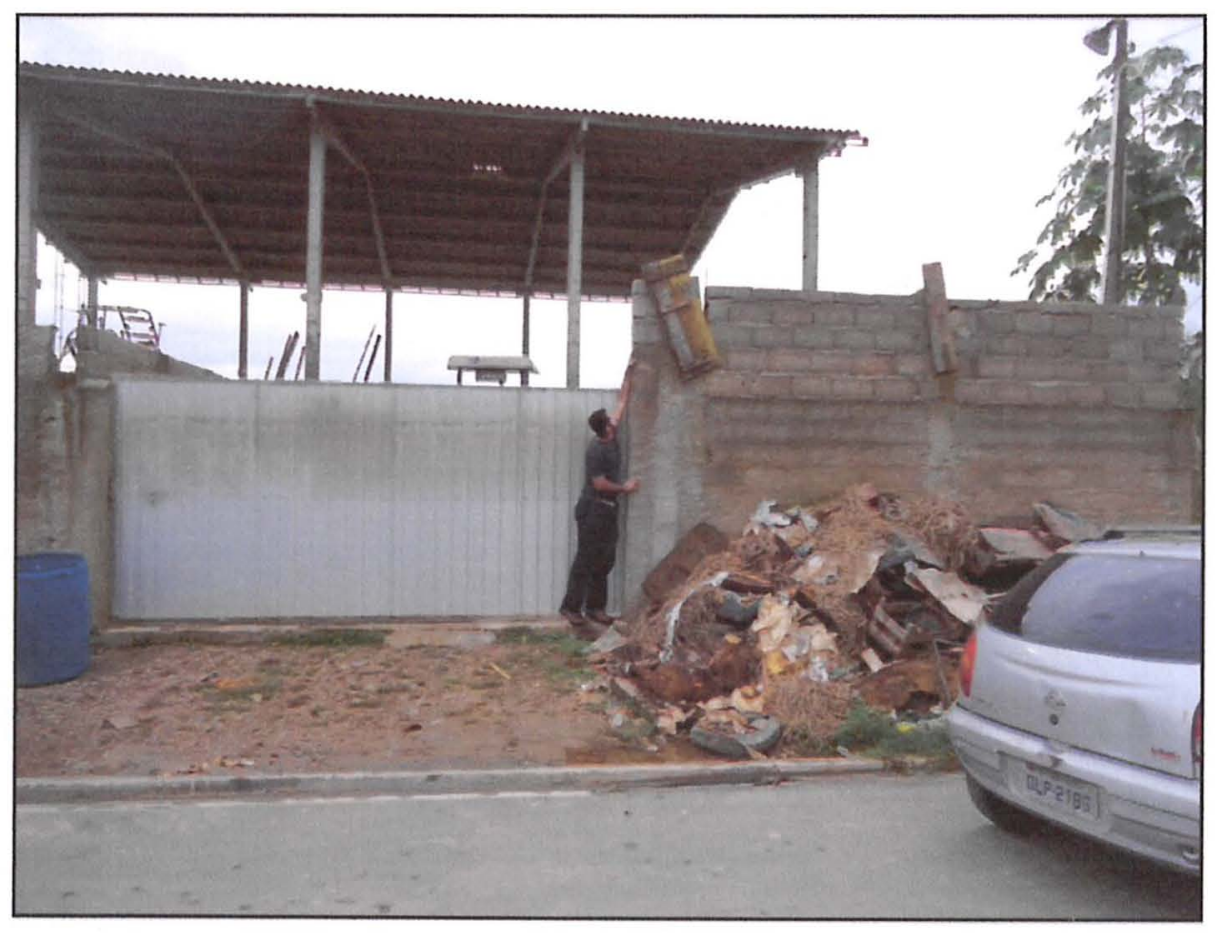

Figura 82. Marca d'água no portão e no muro de uma propriedade ao lado do rio Ribeira de Iguape na cidade de Eldorado. A marca está a cerca de 2,3 $\mathrm{m}$ do nível da rua, cerca de $8 \mathrm{~m}$ a cima do nível normal do rio.

Nas localidades mais proximais da calha do rio, estão ausentes ou são raras as porções de sedimentos finos, sendo predominantes as areias conglomeráticas e os conglomerados médios, com clastos bem arredondados e apresentando forte imbricamento pela corrente fluvial, conforme observado na figura 843 


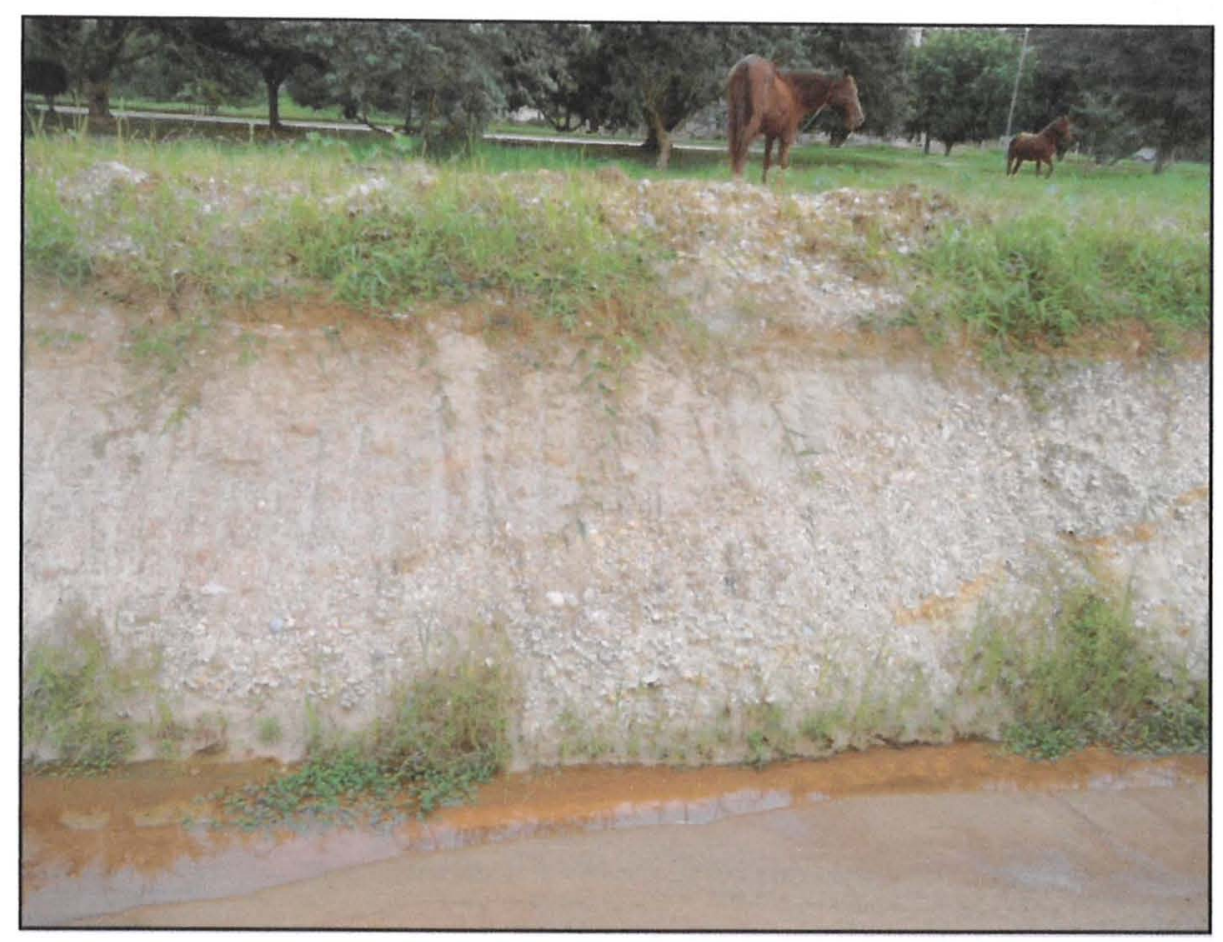

Figura 83. Areias e lentes conglomeráticas da região próxima à calha do rio Ribeira de Iguape, entrada da cidade de Eldorado.

A repetição de sucessivos episódios de corrida de detritos das encostas ao redor da depressão do Baixo Ribeira ao longo do Terciário acabou por entulhar o Graben de Sete Barras favorecendo a geração de uma extensa planície aluvionar onde se desenvolveu a atual calha do rio Ribeira de Iguape. Neste contexto, as inundações desta planície fluvial, atreladas ao tectonismo ativo durante o final do Holoceno, foram responsáveis por gerar pelo menos 4 terraços distintos e identificáveis por depósitos aluvionares conglomeráticos e arenosos nos morrotes da região, como observado na figura 84. A sedimentação atual toma tamanha importância na localidade que, em sua porção mais distal (figura 81), a camada de sedimentos é de 3,5 $\mathrm{m}$ de espessura, chegando facilmente às dezenas de metros na porção próxima ao rio atual. 


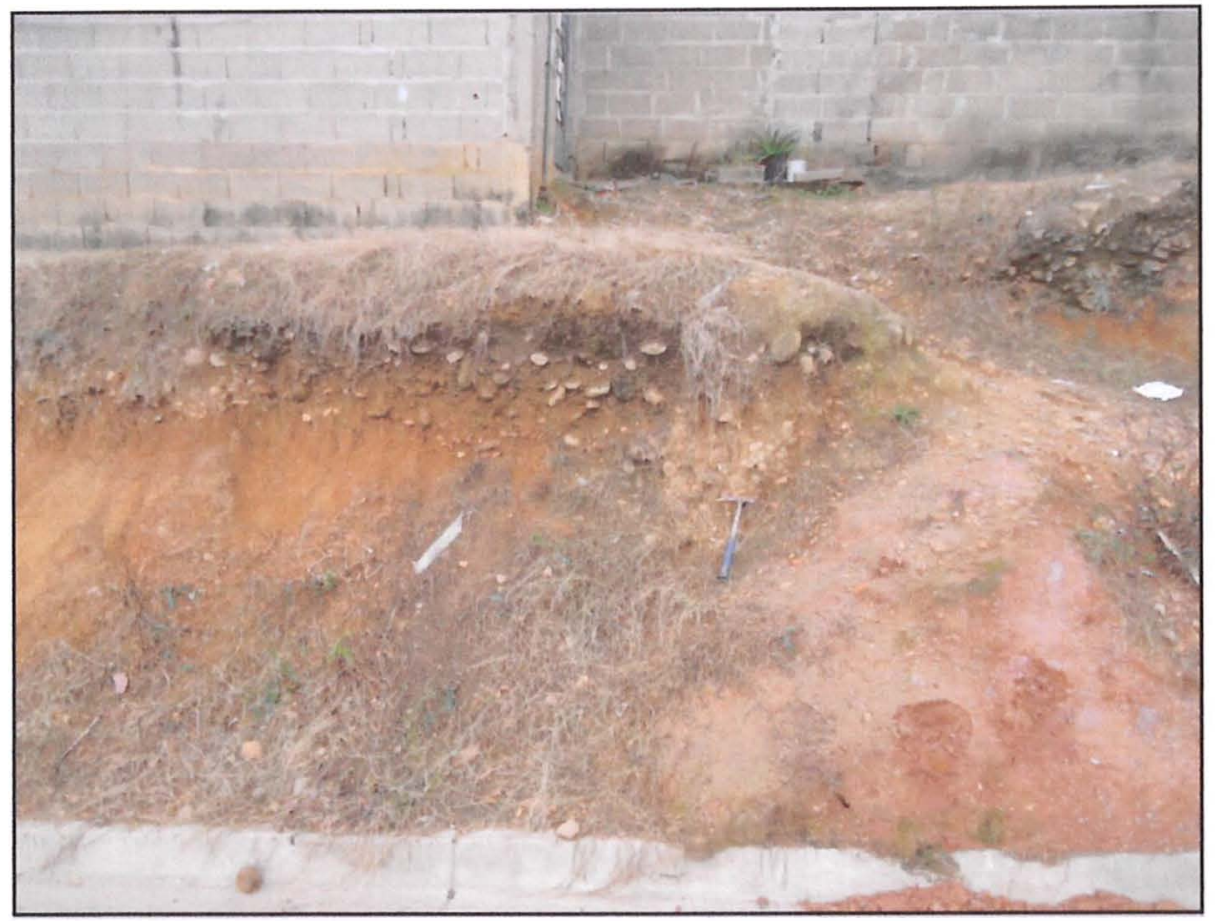

Figura 84. Pacote de seixos arredondados com imbricamento fluvial depositados em morro da cidade de Eldorado, cerca de $40 \mathrm{~m}$ de altura em relação ao nível atual do rio Ribeira de Iguape.

O estudo destas feições sedimentares recentes, por vezes bastante negligenciado por alguns geólogos, é de suma importância para o entendimento da evolução da paisagem da região. Registram-se nestes sedimentos, importantes eventos tectônicos relativos às mudanças de níveis de base locais - formação de terraços - bem como a evidência de um ambiente tectonicamente ativo até pelo menos o Terciário tardio, quando da instalação do Graben de Sete Barras e unidades sedimentares correlatas.

\subsection{3 - GEOLOGIA ESTRUTURAL RÚPTIL}

Como este trabalho tem ênfase no estudo geomorfológico e da evolução da paisagem da região da folha Capão Bonito, optou-se por descrever, a partir dos dados levantados em campo, as características da geologia estrutural rúptil da área, 
de maneira a melhor caracterizar os sistemas de fraturas e falhas responsáveis pela disposição da atual Serra de Paranapiacaba.

Esta parte do trabalho tem como principal meta corroborar todos os outros métodos aplicados nesta tese, principalmente aqueles focados na observação remota, na geomorfologia e na geomorfometria.

Desta forma, fica posta à parte a discussão sobre a geologia estrutural dúctil e dúctil-rúptil da área, esta basicamente associada aos extensos processos de colagem crustal proterozóicos em ambiente transpressional. Foi assumido, portanto, que uma discussão pormenorizada destas características fugiria ao escopo principal do trabalho.

Para a realização deste item, foram utilizadas medidas levantadas a partir de bússola geológica tipo Clar, com posterior geração de diagramas circulares de rede estereográfica a partir do software livre OpenStereo (Grohmann \& Campanha, 2010).

Apesar de se tratar de uma folha 1:100.000, não houve disponibilidade de muitas medidas para esta parte do trabalho. Isto ocorreu por alguns fatores complicantes naturais da região tais como a intensa alteração intempérica dos afloramentos e a cobertura vegetal fechada que muitas vezes dificultava acessos a áreas de interesse, bem como pela decisão, por parte do autor, de obter estas medidas somente a partir da segunda etapa de campo, na esperança de realizar mais uma etapa na região da serrania dos Agudos Grandes a qual, infelizmente, não se completou.

Apesar destes contratempos, foi possivel levantar algumas informações importantes no que tange as principais fraturas envolvidas na área.

Foram obtidas medidas em duas regiões bastante distantes e distintas: à norte da Serra de Paranapiacaba, próximo ao limite com a bacia do Paraná, e no extremo sul, na região do Baixo Ribeira, conforme pode ser observado na figura 85 : 
O interessante é que, ao confrontar os dados obtidos em campo através das projeções estereográficas da figuras 86 , nota-se uma forte correlação entre os dados, sugerindo que as fraturas medidas ocorrem em âmbito regional e são definitivamente as responsáveis pela configuração do relevo da área.

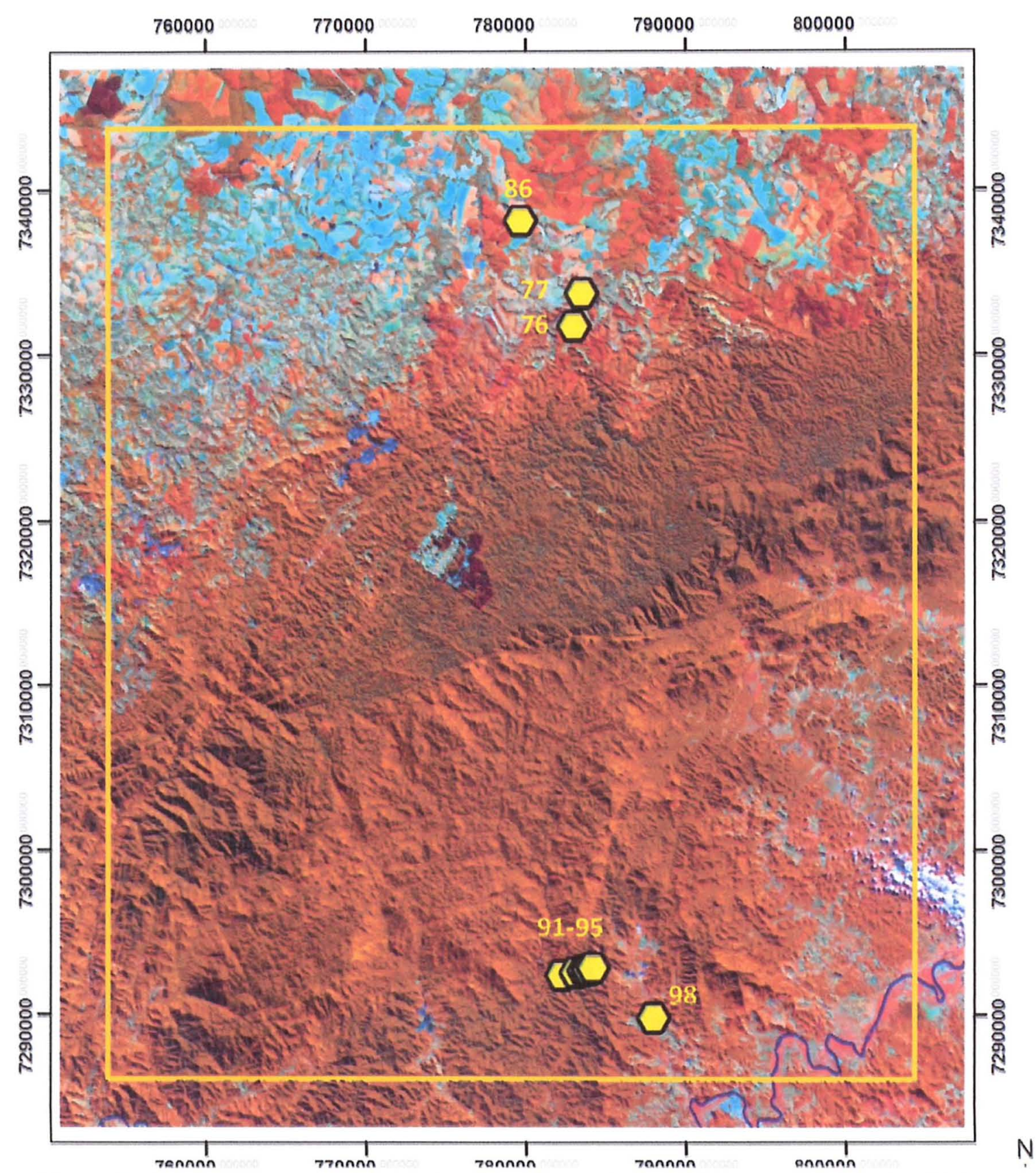

Figura 85. Pontos de coleta de medidas marcados sobre uma imagem IRS bandas $342 \mathrm{em}$ RGR 

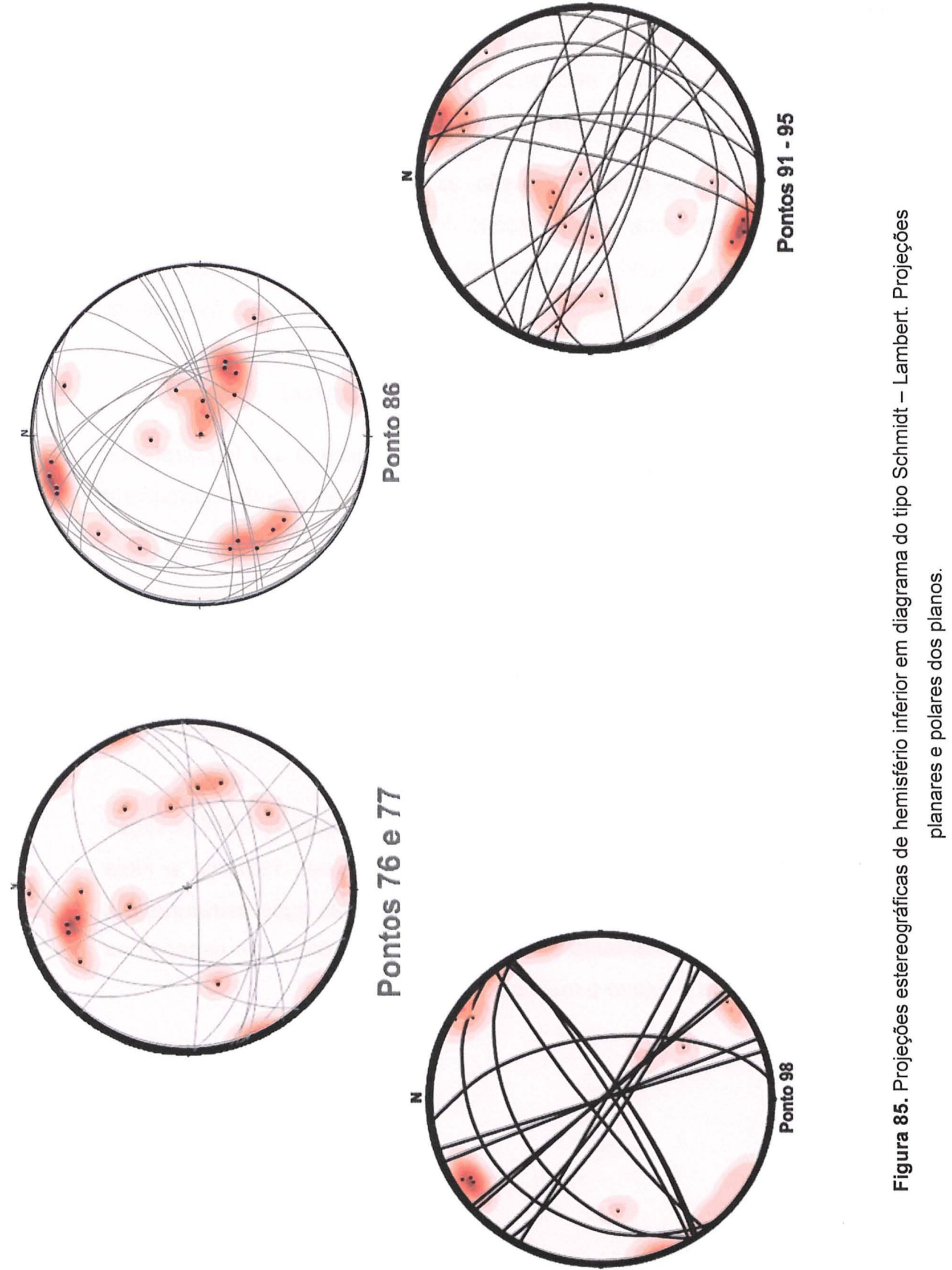
A partir da observação dos estereogramas da página anterior, é possivel identificar em todos os diagramas a presença de pelo menos três famílias de fraturas, as quais se repetem, salvo pequenas mudanças de ângulo de mergulho, nos dois domínios, a norte e a sul da Serra de Paranapiacaba.

Destas três famílias, as dominantes são as estruturas NE-SW com altos mergulhos, responsáveis por gerar aglomerações de projeções polares nas bordas dos estereogramas. Existem ainda significativas ocorrências de estruturas de direção NW-SE, com mergulhos intermediários a altos. Por fim, há fraturas de direção entre N-S e NNE-SSW, melhor observadas nas projeções relativas aos pontos 86,98 e 91-95, com mergulhos próximos do plano horizontal.

As fraturas com mergulhos próximos ao horizontal podem ser interpretadas como juntas de alívio das rochas, desenvolvendo-se quando há grande intensidade de esforços principalmente gravitacionais.

A interação destas três famílias de fraturas e diáclases é muito importante para a configuração do relevo da região de Capão Bonito. Este resultado mostra que os métodos de interpretação remotos são válidos, pois são justamente as direções preferencialmente observadas nos modelos digitais de terreno, e evidenciadas pelo tratamento do método das isobases.

A maior tendência à verticalização observada nas estruturas NE-SW (foliação metamórfica e milonítica) e NW-SE (Alinhamento de Guapiara), reafirma a ideia sugerida pelos sensores remotos de que a interação entre estas duas estruturas é a principal responsável pelo basculamento de blocos em toda a área, em especial na região do Baixo Ribeira onde o relevo é mais abatido. 


\section{Considerações Finais}

A região entre as cidade de Capão Bonito e Eldorado, no sudeste do estado de São Paulo apresenta uma diversidade geológica e geomorfológica ímpar. São aproximadamente $60 \mathrm{~km}^{2}$ onde é possível observar rochas geradas desde o Paleoproterozóico até sedimentos Terciários e recentes. Em um contexto geológico tão diverso, desenvolve-se também uma geomorfologia especialmente complexa.

Este trabalho buscou detalhar a geologia e a geomorfologia da região através de estudos por sensores remotos e idas a campo, caracterizando suas principais diferenças paisagísticas e litológicas. Para tanto, foram realizados estudos de geomorfometria - análise digital de terreno - de geomorfologia - análise visual de fotografias aéreas - estudos por sensores remotos multiespectrais - sensoriamento remoto por geobotânica - além de idas a campo.

Sucintamente, a área é composta por quatro grandes domínios geomorfológicos. Na região norte da folha, temos a Bacia do Paraná (Depressão Periférica Paulista), que se instala sobre as rochas que compõem o Planalto Atlântico - incluindo os Planaltos de S. Roque e de Guapiara. Esta unidade geomorfológica dá espaço, através da abrupta escarpa da Serra de Paranapiacaba, à Depressão do Baixo Ribeira a sudeste e ao Planalto do Ribeira-Turvo, a sudoeste.

Dentre as principais diferenças observadas entre estes extensos domínios, temos a presença de morros e colinas suaves a norte, com grandes distâncias interfluviais, característicos dos Campos Gerais, na Bacia do Paraná. O Planalto Atlântico, por sua vez, apresenta intrincada trama de drenagem, entalhada em vales abruptos e em ' $\mathrm{V}$ ', os quais, obedecendo ao forte controle estrutural imposto pela foliação metamórfica regional da Faixa Ribeira, apresentam forte caráter direcional NE-SW. A feição geomorfológica mais impactante ao observador é justamente a divisa entre o Planalto Atlântico com os outros domínios geomorfológicos a sul, a extensa escarpa reconhecida em todo Sudeste do Brasil como Serra do Mar (aqui Serra de Paranapiacaba). Para sul, predominam os terrenos baixos da Depressão do Baixo Ribeira e as altitudes intermediárias (cotas em torno dos 100 a $200 \mathrm{~m}$ ) do Planalto Ribeira-Turvo. Na porção extremo sul da folha, destacam-se feições de 
intensa erosão - formação de morros mamelonares, desenvolvimento de ampla planície aluvionar, além das baixas altitudes do terreno.

Buscando melhor compreender esta estruturação geomorfológica, o presente trabalho lançou mão de diversos recursos computacionais para demonstrar a relação entre a evolução do relevo e as rochas que o compõe. As técnicas utilizadas demonstraram que, de maneira geral, o fator condicionante principal para o desenvolvimento da Serra de Paranapiacaba é a interação entre as estruturas NESW do embasamento metamórfico e as estruturas NW-SE, creditadas ao Alinhamento de Guapiara.

A perpendicularidade entre estas estruturas, somada aos fortes caimentos observados nos planos de fraturas por elas desenvolvidos, sugerem que elas são responsáveis por:

1. Facilitar o intemperismo profundo das rochas cristalinas.

2. Facilitar a formação de blocos rochosos 'soltos', com maior tendência à movimentações gravitacionais.

3. Favorecer, através das fortes inclinações, o desenvolvimento de superfícies de escorregamento ideais para todo o tipo de detrito que venha a se desenvolver em suas vertentes.

Embora tenha ficado demonstrado que estas estruturas sejam dominantes em âmbito regional, os estudos realizados por interpretação de modelos digitais de terreno e também aqueles realizados através das imagens aeras, possibilitaram visualizar que outras estruturas, principalmente $\mathrm{N}-\mathrm{S}$ e E-W, também têm um papel importante no controle das drenagens e no desenvolvimento de vales e cerros em toda a área.

Apesar da indiscutível influência estrutural na forma do relevo, outro fator importante no desenvolvimento da paisagem é a variação nas resistências de cada litotipo ao intemperismo. Um exemplo de como é importante o fator litológico na região é a própria Serra de Paranapiacaba que, em sua porção mais proeminente para sudeste é sustentada pelo batólito de Agudos Grandes. Este extenso corpo ígneo serve como um verdadeiro escudo contra a retração da escarpa da Serra do Mar na região, em contrapartida a outras porções da escarpa, mais retraídas devido à presença de litotipos menos maciços como gnaisses, paragnaisses e xistos, os quais são muito mais suscetíveis às ações intempéricas. 
A realização de um estudo geomorfométrico através das linhas de isobases e da comparação de perfis altimétricos paralelos forneceu ainda mais evidências da atuação das estruturas geológicas na instalação da paisagem. O método das isobases evidenciou o controle relativo de cada estrutura na drenagem atual, sendo possivel destacar a importância das estruturas regionais (NE-SW e NW-SE) como as dominantes no controle das drenagens, mas evidenciando também a presença de estruturas N-S e E-W, responsáveis por entalhar drenagens na área em menor escala.

Corroborando estas observações, a análise dos perfis altimétricos paralelos demonstrou o forte escalonamento presente nos blocos rochosos, em especial a sul da Serra de Paranapiacaba. Esta feição foi interpretada como evidência de sucessivos basculamentos gravitacionais ao longo dos planos de falha NE-SW e NW-SE desde o Terciário.

A hipótese do escalonamento da escarpa da Serra de Paranapiacaba é incondicionalmente associada a um momento de reativações tectônicas ao longo da costa Sudeste do Brasil. Estes episódios foram os responsáveis por rejuvenescer o relevo da Serra do Mar, além de gerar as bacias do Rift Continental do Sudeste do Brasil, do qual faz parte a pequena bacia do Graben de Sete Barras, na região de estudo. Em meio a estas reativações tectônicas, ocorreram ainda magmatismos alcalinos importantes, cujos exemplos também podem ser observados nas proximidades da Folha Capão Bonito, em especial a intrusão Carbonatítica de Jacupiranga.

A ocorrência desta reativação tectônica terciária encontra-se marcada no registro geológico através da sedimentação clástica grosseira que entulhou a depressão de Sete Barras, em um sistema de leques aluvionares proximais associados aos escarpamentos do entorno. Este tipo de sedimentação é típico de um ambiente com fortes gradientes em clima úmido, favorável ao desenvolvimento de fluxos de detritos, os quais, com a evolução da paisagem local, foram gradativamente substituídos pelas atuais planícies de inundação de rios meandrantes. 
AB'SÁBER, A. N. 1956. A terra paulista. Boletim Paulista de Geografia, (23), 1956.

AB'SÁBER, A. N., 1957. Geomorfologia do Sítio urbano de São Paulo. Tese de Doutoramento. Faculdade de Filosofia, Ciecias e Letras da Universidade de São Paulo. SP. Edição fac-símile - Atelié Editorial, 2007.

ALGARTE, J.P. 1974. Projeto Sudeste do Estado de São Paulo; Relatório Final. São Paulo, Convênio DNPM/CPRM.

ALMEIDA, F.F.M. de. 1953. Considerações sobre a geomorfogênese da Serra de Cubatão. Boletim Paulista de Geografia, São Paulo, v. 15, p. 3-17.

ALMEIDA, F.F.M. 1956. Novas ocorrências de fósseis mo Pré-Cambriano brasileiro. In Anais da Academia Brasileira de Ciências, São Paulo 28 (4) 54-55

ALMEIDA, F.F.M. de. 1958. O Planalto Paulistano. In: Azevedo, A. de. A cidade de São Paulo. São Paulo, v. I, p. 113-167. (v. I, A Região de São Paulo).

ALMEIDA, F.F.M. 1974. Fundamentos geológicos do relevo paulista. $99 \mathrm{p}+$ material cartográfico.

ALMEIDA, F.F.M. \& CARNEIRO, C.D.R. 1998. Origem e Evolução da Serra do Mar. In: Revista Brasileira de Geociências 28(2): 135-150, junho de 1998.

ALMEIDA, M.A. de; BISTRICH, C.A.; STEIN, D.P. 1986. A formação Água Clara na região de Araçaíba, estado de São Paulo: litotipos, metamorfismo e deformação. In: Congresso Brasileiro de Geologia, 34, Goiânia, 1986. Anais... Goiânia, SBG. V 2 p. 905-918.

ALMEIDA, T.I.R. \& SOUZA FILHO, C.R. 2004. Principal component analysis applied to feature-oriented band ratios of hyperspectral data: a tool for vegetation studies. International Journal of Remote Sensing, v. 25, n. 22, p. 5005-5023.

ALMEIDA, T.I.R., Perrotta, M.M., Souza Filho, C.R. SANTOS, M.G.M., 2007. Geobotânica por sensoriamento remoto no mapeamento geológico de região recoberta por floresta amazônica de terra firme: uma avaliação metodológica na região do Vale do Guaporé (RO). 
ALMEIDA, T.I.R. et al. 2009. Application of remote sensing to geobotany to detect hydrotermal alteration facies in epithermal high-sulfidation gold deposits in the amazon region. In Reviews in economic geology, V16, p135-142. Society of Economic Geologists. Chelsea, 2009.

ANDRADA, M.F.R. 1805. Diário de uma viagem mineralógica pela província de São Paulo no ano de 1805. In Boletim Paulista de Geografia (18), pp 34 - 44, 1954.

ANDRADA E SILVA, J.B. \& FRANCISCO, M. 1829. Voyage mineralogique dans La province de Saint Paul, Brésil. Bulletin de SciencesNaturelles et de Geologie, XVI, 411-415, 8, Paris. In Obras científicas, políticas e sociais de José Bonifácio de Andrade e Silva / coligidas e reproduzidas por Edgard de Cerqueira Falcão.Empresa gráfica da: Revista dos Tribunais LTDA. São Paulo.

BARBOSA, O. 1948. A chamada Série Ribeira. Min. Metal. São Paulo, 13 (79): $187-$ 189.

BASEI, M.A.S.; SIGA Jr., O.; REIS NETO, J.M. 1990. O batólito Paranaguá. Proposição, idade, considerações petrogenéticas e implicações tectônicas. In: CONGRESSO BRASILEIRO DE GEOLOGIA, 36, Natal. Aanais, Natal, SBG, v.4, p 1684-1699.

BASEI, M.A.S.; SIGA Jr., O.; MACHIAVELLI, A.; MANCINI, F. 1992. Evolução Tectônica dos terrenos entre os cinturões Ribeira e Dom Feliciano (PR-SC). Revista Brasileira de Geociências, 22 (2): 216-221

BASEI, M.A.S.; SIGA Jr. O.; KAULFUSS, G.A. CORDEIRO, H.; NUTMAN, A.; SATO, K.; CURY, L.F.; PRAZERES FILHO, H.J.; PASSARELLI, C.R.; HARARA, O.M.; REIS NETO, J.M.; WEBER, W. 2003. Geochronology and isotope geochemistry of Votuverava and Perau Mesoproterozoic basins, Southern Ribeira Belt, Brazil.In: IV South American Symposium on Isotope Geology, Short Papers: 501-504.

BIGARELLA, J.J. \& MOUSINHO, M.R. 1965. Contribuição ao estudo da Formação Pariquera-Açu (Estado de S. Paulo). In: Boletim Paranaense de Geografia (16/17):17-41. 
BIGARELLA, J.J, 1948. Estudos preliminares na série Açungui. II - Rochas calcárias. Arq. de Biol. e Tecn. Vol III, p. 201-354. Curitiba

BIGARELLA, J.J. \& SALAMUNI, R. 1956. Estudos preliminares na série Açungui V Estruturas organógenas nos dolomitos da formação Capirú (Estado do Paraná). Dusenia VII (6), PP 317-323 - Curitiba.

BIGARELLA, J.J. \& SALAMUNI, R. 1958. Contribuição à Geologia da região Sul da série Açungui (Estado do Paraná). In Boletim Paulista de Geografia (29) PP 3-19. São Paulo.

BOLONINI, T.M. \& GODOY, A.M. 2012. Caracterização tecnológica das rochas ornamentais do maciço Capão Bonito, SP. In Geociênc. (São Paulo) [online]. 2012, vol.31, n.2, pp. 229-246. ISSN 0101-9082.

CAMPANHA, G. A. C. 1991. Tectônica proterozóica no alto e médio Vale do Ribeira, estados de São Paulo e Paraná. Tese de Doutoramento. Instituto de Geociências USP, São Paulo.

CAMPANHA, G.A.C.; \& FALEIROS, F.M. 2005. Neoproterozoic terrane collage in the southern and central Ribeira Belt, Brazil. In: Gondwana 12 conferece: geological and biological heritage of Gondwana. National Academy of Sciences, Mendoza, Abstracts, v. 1, p. 81.

CAMPANHA, G.A.C.; HACHIRO, J.; BISTRICHI, C.A.; 1985. Mapa geológico das folhas Iporanga (SG-22-X-B-V-2) e Gruta do Diabo (SG-22-X-B-VI-1). Estado de São Paulo, convênio IPT/CPRM.

CAMPANHA, G.A.C. \& SADOWSKY, G.R. 1999. Tectonics of the Southern Portion of the Ribeira Belt (Apiai Domain).PrecambrianResearch, 98(1) 31-51.

CAMPOS NETO, M. da C. 1983. Contribuição à litoestratigrafia do Grupo Açungui no sudeste do Estado de São Paulo. In Simpósio Regional de Geologia, 4, São Paulo, 1983. Atas São Paulo, SBG p 103-112.

CARNEIRO, C. D. R. , BISTRICHI, C. A. , PONÇANO, W. L. , ALMEIDA, M. A. , ALMEIDA, F. F. M. \& SANTOS, M. C. S. R. 1981 .Mapa Geomorfológico do Estado de São Paulo, ao milionésimo., São Paulo : IPT. Monografias 5, anexoCHIODI 
FILHO, C. 1984. Contribuição à geologia das regiões sul-paulista e leste paranaense, Grupos Açungui e Setuva. In XXXIII Congresso Brasileiro de Geologia, Rio de Janeiro, 1984. Anais, vol. 5, p 2394-2406.

COIMBRA, M.J.B. Sem ano. Radar de abertura sintética - SAR Synthetic apperture RADAR. Em http://paginas.fe.up.pt/ hmiranda/st2/sar.pdf acesso em 05/2012.

COMISSÃO GEOGRÁFICA E GEOLOGICA, 1914. Exploração do Rio Ribeira de Iguape. Ed. Rotschild. São Paulo.

CUTRONA, L.J. 1990. RADAR Handbook.Ed. M. Skolnik. McGraw-Hill, New York.

DAITX E.C. 1996. Origem e evolução dos depósitos sulfetados tipo-Perau (Pb-Zn-Ag), com base nas jazidas Canoas e Perau (Vale do Ribeira, PR). Tese de Doutorado, Instituto de Geociências e Ciências Exatas, Universidade Estadual Paulista Júlio de Mesquita Filho, Rio Claro, 453 p.

DERBY, O.A. 1878. Geologia da região diamantífera da província do Paraná no Brasil. In Arquivo do Museu Nacional, Rio de Janeiro, vol 3, p 89 - 96.

DERBY, 1899. Geologia do SE Paulista, estado de seu conhecimento no fim do século passado. In Boletim de agricultura $\mathrm{n}^{\circ}$ único, 1951. Diretoria de Publicidade Agrícola, São Paulo, 1953.

ESA European Space Agency, 2008- CD-ROM didático 1 - Principles of remote sensing. Em arquivo digital contido no endereço http://www.tiger.esa.int/TrainingCds/cd 01/content 2/sez 2 2/pg2 2 03.htm acessado em 02/2013.

FALEIROS, F. M. 2000. Estratigrafia e tectônica de parte do Subgrupo Lajeado, Iporanga, SP. Trabalho de Conclusão de Curso, instituto de Geociências USP - São Paulo.

FALEIROS, F. M. 2008. Evolução de terrenos tectono-metamórficos da Serrania do Ribeira e Planalto Alto Turvo (SP,PR).. Tese de Doutoramento. Instituto de Geociências USP, São Paulo.

FALEIROS, F.M.; FERRARI, V.C.; COSTA, V.S.; CAMPANHA, G.A.C. 2011. Geoquímica e petrogênese de metabasitos do grupo Votuverava (Terreno Apiaí, 
Cinturão Ribeira Meridional): evidências de uma bacia retroarco calimiana. In Geologia USP, série científica, vol 11, nº 02. São Paulo.

FARR, T. G.; ROSEN, P. A.; CARO, E.; CRIPPEN, R.; DUREN, R.; HENSLEY, S.; KOBRICK, M.; PALLER, M.; RODRIGUEZ, E.; ROTH, L.; SEAL, D.; SHAFFER, S.; SHIMADA, J.; UMLAND, J.; WERNER, M.; OSKIN, M.; BURBANK, D. \& ALSDORF, D., 2007.

The Shuttle Radar Topography Mission. In: Review of Geophysics, 45, RG 2004.

FERNANDES, A.J., 1991. O Complexo Embu no Leste do Estado de São Paulo: Contribuição ao conhecimento da litoestratigrafia e da evolução estrutural e metamórfica. Dissertação de mestrado. Instituto de Geociências da Universidade de São Paulo, 120 p. e anexos.

FIORI, A. P. 1992. Tectônica e estratigrafia do Grupo Açungui - PR. Boletim do Instituto de Geociências, 23: 55-74. Universidade de São Paulo.

FIORI, A.P. 1994. Evolução geológica da Bacia Açungui. Boletim Paranaense de Geociências, Curitiba, PR, 42: 7-27.

FROMAGGIO, A.R.; EPIPHANIO, J.C.N.; \& SIMÕES, M.S. Radar Backscattering from na agricultural scene. In Pesq. agropec. Bras. vol.36 no.5 Brasília Maio 2001.

FUNDACÃO FLORESTAL DO ESTADO DE SÃO PAULO, 2010. Resumo do plano de manejo do parque estadual intervales anexo ao parecer da comissão de biodiversidade do CONSEMA. In Plano de Manejo do Parque Estadual Intervales.

GHOLTS, S. \& ROSENTHAL, E. 1993. A morphometric map of the northern Arava in Israel, derived from isobase lines. In: Geomorphology, 7 p. 305-315. Elsevier, Amsterdam.

GALLAGHER, K.; HAWKSWORTH, C.H.; MANTOVANI, M.S.M. 1994. The denudation history of the onshore continental margin of the SE Brazil, infrared from apatite fission track data. In: Journal of Geophysical Research, 99, n. B9, p.18,11718,145 . 
GROHMANN, C. H. 2004. Morphometric analysis in Geographic Information Systems: applications of free software GRASS and R. Computers \& Geosciences, 30, 1055-1067.

GROHMANN, C. H. 2008. Análise digital de terreno do centro-leste brasileiro. Tese de doutoramento. 227 p. Instituto de Geociências da Universidade de São Paulo.

GROHMANN, C. H.; RICCOMINI, C.; CHAMANI, M. A.C. 2011. Regional Scale Analysis of Landform Configuration with base-level (isobase) maps. In: Hydrology and Earth System Sciences, 15:1493-1504.

HASUI, Y. 1975. Geologia da Folha São Roque. Boletim IG, São Paulo. IGUSP 6: 157-183.

HASUI, Y.; GIMENEZ, A.F.; MELO, M.S. de. 1978. Sobre as bacias tafrogênicas do sudeste brasileiro. In: Congresso Brasileiro de Geologia, 30, 1978. Anais... Recife: SBG, v. I, p. 382-392.

HARTMANN, W.K., RYDER, G., DONES, L., and GRINSPOON, D., 2000, The timedependent intense bombardment of the primordial Earth/Moon system, in Canup, R.M., and Righter, K., eds.,Origin of the Earth and Moon: Tucson, University of Arizona Press, p. 493-512.

HASUI, Y.; CARNEIRO, C.D.R.; BISTRICH, C.A. 1981. O embasamento précambriano e eo-paleozoico em São Paulo. In Instituto de pesquisas tecnológicas de São Paulo (IPT), Mapa geológico de estado de São Paulo, 1:500000. São Paulo, vol.1. (IPT - monografia, 6. Publicação 1184).

HEILBRON, M.; PEDROSA-SOARES , A. C.; CAMPOS NETO, M. C.; SILVA, L. C.; TROUW, R. A. J.; JANASI,V. A. Província Mantiqueira. In: Mantesso-Neto, V.;Bartorelli, A.; Carneiro, C. R.; Brito Neves,B. B. (Org.). Geologia do Continente Sul-Americano- evolução da Obra de Fernando Flávio Marques deAlmeida. São Paulo: Beca, 2004. p. 203-235

HIRUMA, S.T. 1999. Neotectônica no planalto de Campos do Jordão, SP. Dissertação de Mestrado. Instituto de geociências da Universidade de São Paulo. 
HIRUMA, S. T. 2007. Significado morfotectônico dos planaltos isolados da Bocaina. Tese de Doutoramento. 205 p. Instituto de Geociências da Universidade de São Paulo. (T H671 ST)

HIRUMA, S.T.; RICCOMINI, C.; MODENESI-GAUTTIERI, M.C.; HACKSPACHER, P.C.; HADLER NETO, J.C.; FRANCO-MAGALHÃES, A.O.B. 2010. Denudation history of the Bocaina Plateau, Serra do Mar, southeastern Brazil: Relationships to Gondwana breakup and passive margin development.Gondwana Research, 18: 674687.

HOTELING, H. 1933. Analysis of a complex of statistical variables intro principal components. In: Journal of educational psychology. Columbia University.

HUTCHINSON, M.F. \& GESSLER, P.E. 1994.Splines - more than just a smooth interpolator. In Geoderma, v. 62 pp. 45-67.

IGG, 1974. Reconhecimento geológico e mineralógico de algumas regiões no Vale do Ribeira de Iguape.

JANASI, V.A. 2003. O magmatismo granítico Neoproterozoico na porção central da Província Mantiqueira. In: VIII simpósio de Geologia do Sudeste, resumos, p. 13. São Pedro, SP.

KNECHT, T. 1939. Ouro no Estado de São Paulo. In Boletim do Instituto Geográfico e Geológico. № 26. São Paulo.

LÓPES JR. I. 2005. Atlas Geoquímico do Vale do Ribeira

MACHIAVELLI, A.1991. Os granitóides deformados da Região de Piên (PR): Um provável arco magmático do Proterozóico Superior. São Paulo. Dissertação de mestrado. Instituto de Geologia da Universidade de São Paulo.

MACHIAVELLI, A.; BASEI, M.A.S.; SIGA Jr., O. (1993). Suite Granítica Rio Piên: um arco magmático do proterozóico Superior In Congresso Brasileiro de Geoquímica, 3, São Paulo. Resumos. São Paulo, SBGq, v.1, p.249-253.

MARCUZZO, F.F.N.; CARDOSO, M.R.D. \& MELLO, L.T.A. 200?. Uso dos Métodos de Krigagem e Spline de Tensão no Mapeamento de Chuvas na Região metropolitana de Goiânia e seu entorno. Arquivo digital. Acessado em 26/03/2012. Disponível em http://www.cprm.gov.br/publique/media/Evento Uso Marcuzzo.pdf. 
MARTINELLI, M. 2009. O Relevo do Estado de São Paulo. In: CONFINS Revue Franco-Brésilienne de Géographie.. posto online em 09 Novembro 2009, Consultado o 23 Maio 2012. URL : http://confins.revues.org/6168 ; DOI : 10.4000/confins.6168

MAWE, J. 1812. Travels in the Interior of Brazil.

MILANI, E.D.; MELO, J.H.G.de; SOUZA, P.A. de; FERNANDES, L.A.; FRANÇA, A.B. 2007. In: Boletim de Geociências de Petrobrás, Rio de Janeiro, v. 15, n 2, p 265287.dsds

MELO, M.S.; FERNANDES, L.A.; COIMBRA, A.M. \& RAMOS, R.G.N. 1989. O Graben (terciário?) de Sete Barras, Vale do Ribeira de Iguape, SP. In: Revista Brasileira de Geologia 19(2) 260-262.

MORAES REGO, L.F. 1941. Geologia do Estado de São Paulo. Separata do boletim do DER. São Paulo. (558.161 R343g)

MOREIRA, J.L.P. et al. 2007 Bacia de Santos. In: PETROBRÁS. Cartas Estratigráficas.PETROBRAS: Boletim de Geociências, Rio de Janeiro, v.15, $n^{\circ} 2$, pág. 531-539, maio/nov. 2007.

NASA Landsat Program, 2001. Landsat sensor ETM+, Scene WRS-2 Path 220, Row 77, september/26/2001, orthorectified - Geocover. Sioux Falls, South Dakota: USGS. Source: University of Maryland, Earth Science Data Interface (ESDI) at the Global Land Cover Facility (GLCF): http://glcfapp.glcf.umd.edu:8080/esdi/index.jsp (access in august/20/2011).

NELSON, S.A. 2012. Physical Geology Class Material. Material didático online em http://www.tulane.edu/ sanelson/eens1110/streams.htm. Acessado em julho 2013.

NRSA - National Remote Sensing Agency 2004. IRS-6 : Data User's Manual Resourcesat 1: data user's handbook. 137 p. PDF online.

NRSA - National Remote Sensing Agency 2010. Resourcesat 1 sensor LISS III, path 330, row 95, april/21/2010, do acervo do INPE (www.inpe.gov.br) acesso em 25/04/2012.

OLIVEIRA, E. P. 1927. Geologia e recursos minerais do estado do Paraná. Monografia VI. Ministério da Agriculuta, Indústria e Comércio - Serviço Geológico e Mineralógico do Brasil. Ed. Mendonça Machado \& Ca. Rio de Janeiro.

Pereira, M.J., Feijó, F.J. 1994. Bacia de Santos. Boletim de Geociências da PETROBRAS, 8(1):219-234. 
PERROTTA, M. M. 1997. Potencial aurífero de uma região no Vale do Ribeira, São Paulo, estimado por modelagem de dados geológicos, geoquímicos, geofísicos e de sensores remotos num sistema de informações geográficas. Tese de Doutoramento. Instituto de Geociências, USP, São Paulo.

PERROTTA, M.M., ALMEIDA, T.I.R., ANDRADE J.B.F., SOUZA FILHO, C.R., RIZZOTTO, G.J. \& SANTOS, M.G.M. 2008. Geobotânica por sensoriamento remoto e aerogamaespectrometria aplicados ao mapeamento geológico da Amazônia: um estudo comparativo no vale do Guaporé (MT). In Revista Brasileira de Geociências 38(1):155-158, março 2008.

PERROTTA, M.M., ALMEIDA, T.I.R., SOUZA FILHO, C.R., BAHIA, R.B.C., COSTA, U.A.P., SPLENDOR, F., REIS, N.J., BETIOLLO, L.M. 2009. Geobotânica por sensoriamento remoto como ferramenta no mapeamento geológico de área de floresta amazônica, uma aplicação na região de Apui-Nova Aripuanã (AM). In Anais do XIV Simpósio Brasileiro de Sensoriamento Remoto, Natal, Brasil, 2009, INPE, p 3293-3300.

PETRI, S. \& SUGUIO, K. 1969. Sôbre os metassedimentos do grupo Açungui do extrêmo sul do Estado de São Paulo. Convênio D.A.E.E. U.S.P. São Paulo.

PETRI, S. \& SUGUIO, K. 1973. Stratigraphy of the Iguape-Cananéia lagoonal region sedimentary deposits, São Paulo state, Brazil: part II. Heavy mineral studies, microorganism inventories and stratigraphical interpretations. Bol. I.G. São Paulo 4:71-85.

PIRES, PIRES, F. A. 1988. Uma nova concepção para os ambientes do Grupo Açungui, na região de Iporanga e Apiaí, Sul de São Paulo. In: CONGR. BRÁS. GEOL., 35. Belém, 1988. Anais... Belém, SBG. v.2, p. 606-616.

QUANTUM GIS DEVELPOMENT TEAM, 2012 Quantum GIS Geographic Information System. Open SourceGeospatial Foundation Project. http://agis.osgeo.org

RICCOMINI, C. 1989. O Rift continental do sudeste do Brasil. São Paulo: Instituto de Geociências Universidade de São Paulo. (Tese de Doutoramento). 
RICCOMINI, C. ET AL 2004: O Rift Continental do Sudeste do Brasil. In: MantessoNeto, V.;Bartorelli, A.; Carneiro, C. R.; Brito Neves,B. B. (Org.). Geologia do Continente Sul-Americano- evolução da Obra de Fernando Flávio Marques deAlmeida. São Paulo: Beca, 2004. p. 203-235

RICCOMINI, C.; MELO, M.S.de; CARNEIRO, C.D.R.; ALMEIDA, F.F.M.de; MIOTO, J.A.; HASUI, Y. 1983. Sobre a ocorrência de um derrame de ankaramito na Bacia de Volta Redonda (RJ) e sua importância na datação das bacias tafrogênicas continentais do sudeste brasileiro. In: Simpósio Regional de Geologia, 4, São Paulo, 1983. Resumos... São Paulo, SBG/NSP. p. 23-24

RODRIGUES, P.C. \& BRANCO, J.A. 2006. A análise de componentes principais sobre dados dependentes. Arquivo digital. Universidade de Lisboa.

ROSS, J.L.S. \& MOROZ, I.C. 1993. Mapa Geomorfológico do Estado de São Paulo. Material cartográfico 1:500.000 + monografia. Departamento de Geografia da Faculdade de Filosofia, Letras e Ciências Humanas da Universidade de São Paulo.

SAADI, A. 1993. Neotectônica da Plataforma Brasileira: Esboço e interpretação preliminares. In: Revista Geonomos1 (1) p 1-15. Instituto de Geociências da Universidade Federal de Minas Gerais. Belo Horizonte.

SABINS, F.F. Jr., 1978 Remote sensing principles and interpretations. San Francisco, W.H. Freemanv

Sallun Filho, W. 1999. Análise dos Estromatólitos do Grupo Itaiacoca (Proterozóico), ao Sul de Itapeva, SP. Dissertação de mestrado, Instituto de Geociências/USP, São Paulo, 126p

SIGA JUNIOR, 1995. Domínios tectonicos do sudeste do Paraná e nordeste de Santa Catarina: geocronologia e evolução crustal. Tese de Doutoramento, Instituto de Geociências da Universidade de São Paulo, 212 p.

SMITH, L.I. 2002. A tutorial on Principal Components Analysis. In http://www.cs.otago.ac.nz/cosc453/student tutorials/principal components.pdf acesso em 01/2013. 
SOARES, J.V. Sem ano. Fundamento de sensoriamento remoto por RADAR. Obtido em www.dsr.inpe.br/dsr/vianei/radar/DOCs PDFs/Livro Radar.pdf, Acesso em 05/2012.

Strahler, A. N. (1971). Earth sciences. New York: Harper \& Row.

TAKAHASHI, A. T.; FERREIRA, J. C. G.; THEODOROVICZ, A. 1983. Projeto Capão Bonito, Relatório final, vol.1. Companhia de Pesquisa de Recursos Minerais, SUREG-SP. São Paulo.

TAKAHASHI, A. T.; FERREIRA, J. C. G.; THEODOROVICZ, A. 1984. Projeto Guapiara, Relatório final, vol.1. Companhia de Pesquisa de Recursos Minerais, SUREG-SP. São Paulo.

TUTIC', D.; LAPAINE, POSLONCEC-PETRIC',V. 2006. Some Experiences in Analytical Relief Shading. Publicação On-line em http://www.mountaincartography.org/publications/papers/papers bohinj 06/25 Tutic Lapaine Posloncec.pdf, acessado em 20/05/ 2012.

VALENTIM, J.L. 2000. Ecologia numérica: uma introdução à análise multivariada de dados ecológicos. Rio de Janero, Ed. Interciência.

VIGNOL-LELARGE, M.L.M.; SOLIANI JR., E.; POUPEAU, G. 1994. Datação pelos traços de fissão do domínio meridional da Serra do Mar (Arco de Ponta Grossa Brasil). In: Congresso Brasileiro de Geologia, 38. Balneário Camboriú, SC. SBG v. 2, p 379-380.

VINVINI, L. \& SOUZA, A.M. 2005. Análise Multivariada da teoria à prática. Tese de especialização. Universidade Federal de Santa Maria, RS. 
ANEXOS 


\title{
Aplicação do método de isobases no mapeamento da folha Capão Bonito (SG- 22-X-B-III), SE do Estado de São Paulo
}

\author{
Renato dos Santos Neves Kahwage ${ }^{\text {; }}$ Carlos Henrique Grohmann ${ }^{1}$; Frederico Meira Faleiros ${ }^{2}$; \\ ${ }^{1}$ IGC-USP; ${ }^{2}$ CPRM - SUREG-SP
}

RESUMO:A região da Faixa Apiaí-Ribeira situada a SE do estado de SP e a NE do estado do PR é classicamente uma região de geologia complexa à qual se devem amplas discussões estratigráficas e geotectônicas. Sua geologia compreende rochas supracrustais neoproterozóicas de grau metamórfico fraco a moderado - Grupo Açungui - colocadas por sobre um embasamento gnáissicomigmatítico de alto grau, e posteriormente ao metamorfismo regional, intrudidas pelo batólito granítico de Agudos Grandes e diversos outros plútons menores: Aboboral, Capuava, Espírito Santo. A norte, afloram os arenitos e folhelhos cretácicos do Grupo Bauru.

A direção estrutural predominante é NE-SW, a qual condiciona a maioria dos contatos entre formações e terrenos tectônicos adjacentes, além de ser a direção da foliação regional. Há ainda, falhas de porte regional e direção NW-SE - relacionadas à intrusão dos diques básicos do Arco de Guapiara - e inflexões bruscas destas estruturas a NNWISSE reconhecíveis mesmo abaixo da Bacia do Paraná, perfazendo pelo menos 3 famílias de falhas.

O objetivo do presente trabalho é mostrar o resultado da aplicação de dados de elevação SRTM (Shuttle Radar Topography Mission) no entendimento da geologia estrutural regional da folha 1:100.000 Capão Bonito. Foram realizadas duas abordagens: a geração de relevos sombreados e a utilização do método das isobases.

O método dos relevos sombreados consiste em confeccionar 4 diferentes imagens com os respectivos azimutes solares em $0^{\circ}, 45^{\circ}, 90^{\circ}$ e $315^{\circ}$. Isto realça lineamentos que tenham ficado em zona de sombra durante o levantamento dos dados, possibilitando a visualização de mais estruturas.

O método das isobases consiste em selecionar drenagens de determinada ordem da bacia hidrográfica em questão, e realizar uma interpolação entre os pontos de intersecção das drenagens escolhidas com as linhas de cota. Isto acaba por salientar as quebras de relevo associadas a estas drenagens, sugerindo, portanto, quais direções seriam as tectonicamente mais ativas na atualidade. Neste trabalho foram utilizadas as drenagens de $2^{\mathrm{a}}$ e $3^{\mathrm{a}}$ ordens extraídas do modelo SRTM.

Como resultado do processo, foi constatada uma forte tendência a reativações e/ou movimentações menores nas falhas e fraturas de direção NW-SE, que apesar de não serem dominantes no contexto geológico-estrutural regional, podem apresentar extensão de dezenas de quilômetros e grande profundidade crustal.

A realização de um trabalho de campo de âmbito regional mostrou contatos de terraços aluvionares terciários - Formação Pariquera-Açu e correlacionáveis - com rochas metamórficas de alto grau do Complexo Embu, feição que corrobora movimentação ativa nestas falhas desde pelo menos o terciário e sustenta o inferido pelo método computacional.

PALAVRAS CHAVE: Faixa Apiaí, Neotectônica, SE São Paulo 



\title{
Análise geomorfométrica da região da folha Capão Bonito (SG-22-X-B-III), SE do estado de São Paulo: Implicações neotectônicas na porção sul da Serra de Paranapiacaba e Gráben de Sete Barras
}

\author{
Renato dos Santos Neves Kahwage ${ }^{1}$ \\ Carlos Henrique Grohmann ${ }^{1}$ \\ ${ }^{1}$ Instituto de Geociências - Universidade de São Paulo \\ Rua do Lago, 562, Cidade Universitária - São Paulo - SP, Brasil \\ renato.kahwage@usp.br \\ guano@usp.br
}

\begin{abstract}
The Southeastern region of Brazil, at the Atlantic border, is known for the existence of a regional scale range named Serra do Mar. This geomorphological feature extends for approximately $1000 \mathrm{~km}$ at NE-SW direction, from the state of Rio de Janeiro to the state of Santa Catarina. It divides two very distinct geological and geomorphological environments - at East, the coastal plains, covered by quaternary shallow marine sediments - and at West, the higher grounds of the Plantalto Atlântico, composed by the metamorphic rocks of the Ribeira fold belt and its granitic intrusions. At the study area the segment of the Serra do Mar is known as Serra de Paranapiacaba. It is a very steep scarp with heights reaching $850 \mathrm{~m}$ and is the northern border of a small rift basin known as the Guapiara Graben, dimensioning about $20 \times 5 \mathrm{~km}$. Evidences of neotectonic events related to the uplift of Serra do Mar Range and to the tafrogeny of the Continental Rift of the Southeastern Brazil are being studied at this work through the application of geomorphometry, mainly concerning the isobase method, interpreted along with other DEM treatment methods. The results suggests that the neotectonic movements at the area occur due to reactivation of ancient structures during the late paleogene, i.e.: the regional foliation of the metamorphic rocks from the Proterozoic (NE-SW) and a perpendicular series of structures NW-SE called the Guapiara Lineament, dated from the late Jurassic.
\end{abstract}

Palavras-chave: Morphometry, geomorphology, neotectonics, Southeastern Brazil, morfometria, geomorfologia, neotectonica, Sudeste do Brasil.

\section{Introdução}

Uma das feições morfológicas mais marcantes do sudeste brasileiro é a escarpa da Serra do Mar. Tem em média 700 metros de elevação por cerca de $1.000 \mathrm{~km}$ de extensão na direção NE-SW e separa dois ambientes geomorfológicos e geológicos distintos: as planícies costeiras a Leste - preenchidas por cordões litorâneos antigos - e o Planalto Atlântico a Oeste formado pelas rochas metamórficas do cinturão Ribeira e suas intrusivas graníticas.

Na região da área de estudo, porção Sul do estado de São Paulo, a Serra do Mar é conhecida por Serra de Paranapiacaba. Localmente, apresenta altitudes com torno dos $850 \mathrm{~m}$ e é o limite norte de uma depressão alongada de cerca de $20 \mathrm{~km}$ de extensão por até $7 \mathrm{~km}$ de largura conhecida como Gráben de Sete Barras, próximo à cidade homônima.

Evidências de eventos neotectônicos relacionadas ao soerguimento da Serra do Mar e à tafrogenia do Rift Continental do Sudeste do Brasil serão abordadas neste trabalho através da aplicação da geomorfometria, principalmente com a utilização do método das isobases interpretado juntamente com outros produtos obtidos através do modelo digital de terreno (MDT).

Os resultados sugerem que o principal mecanismo de movimentação neotectônica seja a reativação das estruturas pretéritas presentes na área, principalmente a foliação regional NESW (meso-neoproterozóica), e as estruturas perpendiculares NW-SE, do alinhamento de Guapiara, de idade jurássica. 


\section{Metodologia de trabalho}

Os métodos de pesquisa aplicados a este trabalho visaram a utilização de dados de elevação SRTM (Shuttle Radar Topography Mission) como ferramenta para a análise digital de terreno e a geomorfologia. As técnicas aplicadas a este conjunto de dados englobam:

a) Extração de lineamentos através da geração de relevos sombreados com diferentes posições de azimute solar.

b) Elaboração de perfis de altitude direção NW-SE

c) Aplicação do método de isobases (Filosofov, 1960).

Por ser um método pouco convencional, mas com aplicações importantes na área da neotectônica, o método das isobases será detalhado a seguir. Consiste em uma técnica utilizada para relacionar a topografia com as diferentes ordens de drenagem. Segundo Powell (1875) um nível de base é caracterizado como o nível a partir do qual as terras secas não podem ser erodidas. Certamente, o nível de base global é o mar, mas local e regionalmente, ocorrem níveis de base referentes às bacias hidrográficas atualmente instaladas. A análise destes níveis pode evidenciar anomalias de drenagem muitas vezes associadas às movimentações tectônicas recentes.

O tratamento consiste em interpolar os valores de altitude dos pontos de intersecção das drenagens previamente hierarquizadas, com as linhas de cota. Os resultados evidenciam lineamentos que fornecem controle estrutural para a instalação das drenagens, geralmente associados a movimentações recentes ao longo destes planos de falhas.

Os passos para a realização desta técnica a partir de um MDT podem ser conferidos na figura 1:

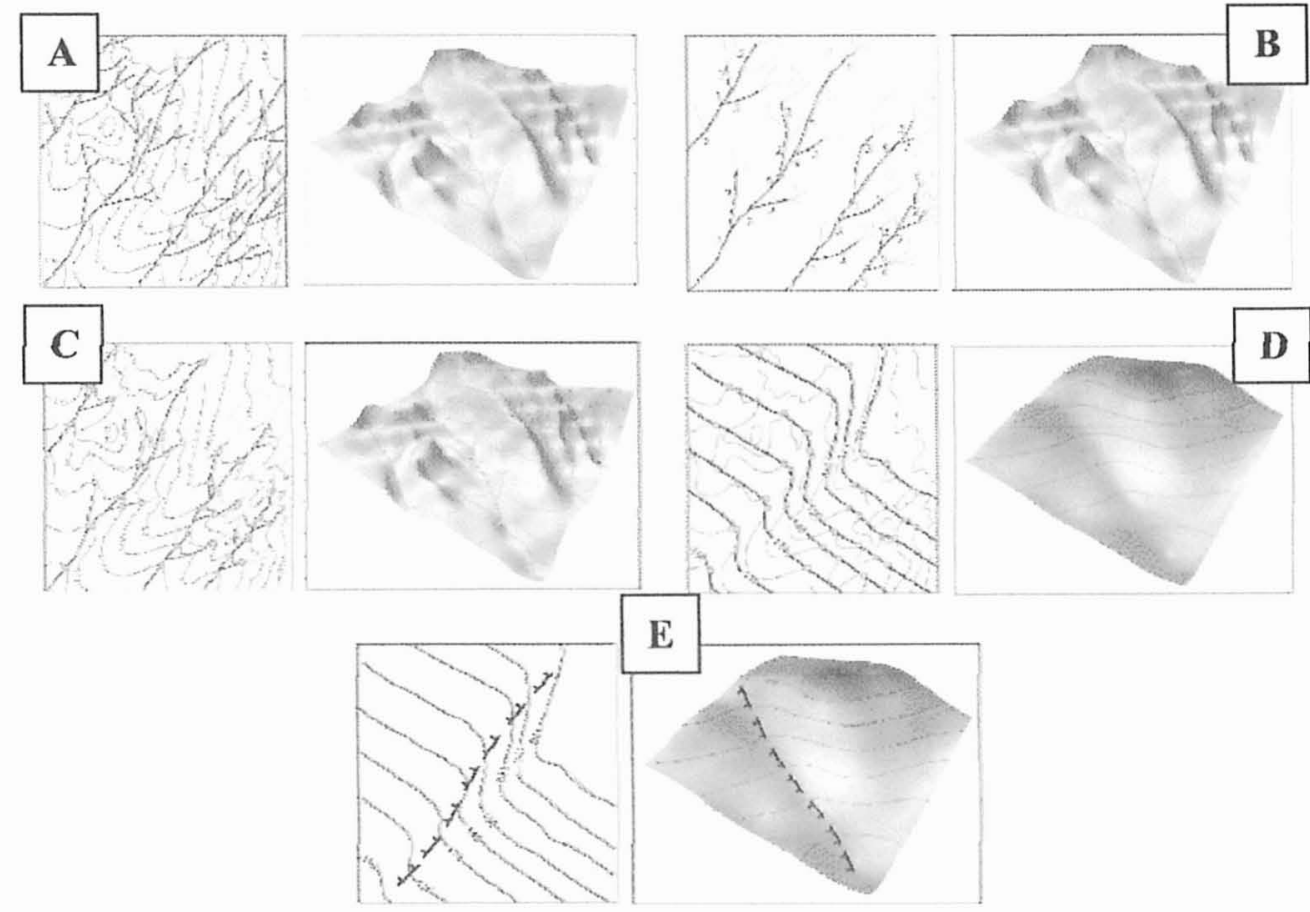

Figura 1. Passos para a realização do método das isobases, modificado de Grohmann et al. 2011. A) Obtenção do Modelo Digital de Terreno e drenagens. B) Classificação das drenagens (Strahler, 1952). C) Extração dos pontos de intersecção das drenagens com as linhas de cota. D) Interpolação dos valores de altitude dos pontos obtidos em C. E). Interpretação dos resultados. 


\section{Resultados e Discussões}

Primeiramente será abordada, de maneira sucinta, a geologia da folha Capão Bonito Figura 2. Em sua porção norte, ocorrem os sedimentos permo-carboníferos da Fm. Itararé da Bacia do Paraná, em contato com as rochas metassedimentares do Grupo Açungui (meso a neoproterozóico). Estas predominam em toda a porção leste e central da folha. Ainda na porção central destaca-se o Batólito de Agudos Grandes, que intrude os metassedimentos e sustenta a Serra de Paranapiacaba na região. A escarpa gera um desnível de cerca de $800 \mathrm{~m}$ até a região do Baixo Ribeira, próxima à cidade de Eldorado. Nesta localidade, afloram rochas pertencentes ao Complexo Embu (paleoproterozóico) e capeadas, localmente, por rochas sedimentares recentes, associadas ao Gráben de Sete Barras e Formação Pariquera-Açu, de idade supostamente terciária. Todas as unidades exceto as terciárias são entrecortadas por diques de rochas básicas de direção NW-SE, associados ao magmatismo toleiítico jurássico da Bacia do Paraná, feição conhecida como Alinhamento de Guapiara.

\section{Legenda}
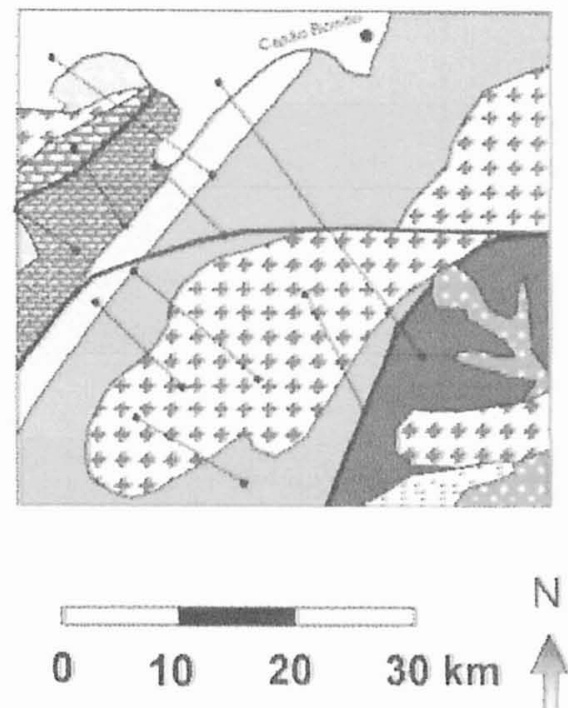

$\square$ Coberturas Cenozoicas

- 3 Diques Básicos Jurässicos

Bacia Sedimentar do Paraná (Permo-Carbonifero)

Terreno Apiai

Granitóides pós-colisionais, tipo A

Formação lporanga (Ediacarano)

Suites Graniticas calcio-alcalinas (Ediacarano)

Grupo Lajeado (Meso a Neoproterozóico)

Serra das Andorinhas (Meso a

Neoproterozoico)

Grupo Votuverava (Mesoproterozoico)

Formaçäo Água Clara (Mesoproterozóico)

Embasamento Gnàissico

(Paleoproterozíico)

Complexo Embu

Figura 2. Esboço geológico da Folha Capão Bonito: escalas e desenhos das unidades aproximados, para simples conferência.

Esta grande heterogeneidade geológica, aliada à tectônica recente perfizeram as condições para o desenvolvimento das diferentes formas de relevo que existem na área: O Planalto Atlântico, a Depressão Periférica Paulista (DPP) e a Depressão Baixo Ribeira.

A porção de relevo mais íngreme é a do Planalto Atlântico, caracterizado por seu escarpamento abrupto (serra de Paranapiacaba) e, a partir desta, por suas serranias com proeminências agudas e vales em ' $\mathrm{V}$ ', além da alta taxa de dissecação atual: característica evidenciada pelos escorregamentos de encosta e voçorocas, muito comuns em toda a extensão da Serra do Mar. Na área de estudo, o Planalto Atlântico pode ser dividido em três diferentes unidades geomorfológicas, conforme proposto por Ross e Moroz (1993), separadas basicamente pelas faixas de altitude, são elas: o Planalto de Guapiara - entre 700-800 m - o Planalto de Ibiuna / São Roque - entre 800 e 900 m - e o Planalto do Ribeira / Turvo - com altitudes acima dos $900 \mathrm{~m}$. 

A norte das porções mais elevadas, já no contexto geológico da bacia sedimentar do Paraná, existe a DPP, localmente designada como Depressão Paranapanema. Apresenta relevo mais abatido, predominando colinas suaves e rampas, sem o forte controle estrutural característico das litologias metamórficas.

Por fim, o extremo sudeste da folha Capão Bonito abriga a Depressão Baixo Ribeira, caracterizada por um relevo muito abatido, em contrapartida ao seu limite norte, a Serra de Paranapiacaba. É marcado pela presença de morros arredondados em 'meia laranja', todos de tamanho muito similar e com espaçamento entre morros constante. Nesta região, destaca-se a presença de depósitos sedimentares terciários em uma bacia tipo Graben alongada na direção NE-SW, o Graben de Sete Barras. Segundo Riccomini (1989) e Melo (1989), esta pequena bacia sedimentar associa-se à tafrogenia do Rift Continental do Sudeste do Brasil, sendo correlata às outras bacias Cenozoicas da borda atlântica, tais como as Bacias de São Paulo, Curitiba, Volta Redonda e Taubaté.

Havendo delineado uma breve descrição do relevo da área e situado os diferentes ambientes geológicos lá ocorrentes, a discussão segue adiante através dos resultados obtidos após os tratamentos em MDTs. Em primeira instância, foi realizado o levantamento das estruturas geológicas da área: falhas, fraturas e lineamentos. As direções destas estruturas foram postas em um diagrama de rosácea para melhor visualização de frequência e azimute, conforme na figura 3. Puderam ser individualizadas quatro famílias de estruturas, das quais predominam aquelas de direção NE-SW - foliação metamórfica regional - e NW-SE direção associada aos diques básicos do Alinhamento de Guapiara. Estruturas E-W e N-S são menos frequentes e podem desenvolver controle estrutural em drenagens, conforme será mostrado mais adiante (figura 5).

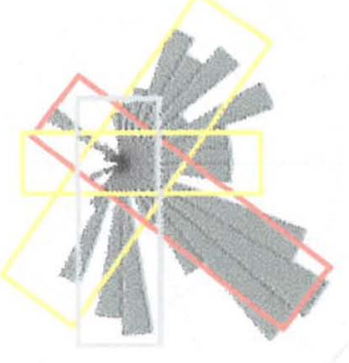

Figura 3. Diagrama em roseta dos lineamentos obtidos após interpretação de relevos sombreados em quatro direções de azimute solar: $0^{\circ}, 45^{\circ}, 90^{\circ}$ e $315^{\circ}$. Famílias de fraturas em destaque. Família NW-SE (vermelho), família NE-SW (laranja), família E-W (amarelo), família N-S (cinza).

A realização de perfis paralelos de direção NW-SE (figura 4b e 4c), passando pela região da Serra de Paranapiacaba, evidencia a presença de superfícies escalonadas. A porção mais a SE, após a escarpa principal, é composta por pelo menos 3 níveis de erosão diferentes, provavelmente representando superfícies individualizadas por falhamentos normais paralelos. Estes níveis se encontram em altitudes em torno dos $500 \mathrm{~m}, 300 \mathrm{~m}$, e $100 \mathrm{~m}$, e podem ser interpretados como resultantes da erosão remontante da escarpa da Serra do Mar, podendo representar antigas posições da escarpa durante o terciário. 
Na porção mais abatida, no extremo SE do perfil, nota-se a predominância de picos de até $100 \mathrm{~m}$, além da abundância de elevações com valores em torno dos $50 \mathrm{~m}$. Foram realizados perfis de detalhe nesta região (figura 4b), os quais corroboram a ocorrência de morros de até $100 \mathrm{~m}$ de altitude, que se elevam sobre terras baixas entre 25 e $50 \mathrm{~m}$. Nestas regiões mais planas, ocorrem três prováveis níveis de base antigos, pertencentes à Bacia do Baixo Ribeira e associados ao desenvolvimento do Graben de Sete Barras. Seriam representados pelas altitudes em torno dos $50 \mathrm{~m}$, dos $35 \mathrm{~m}$ e o nível atual, abaixo dos $25 \mathrm{~m}$.

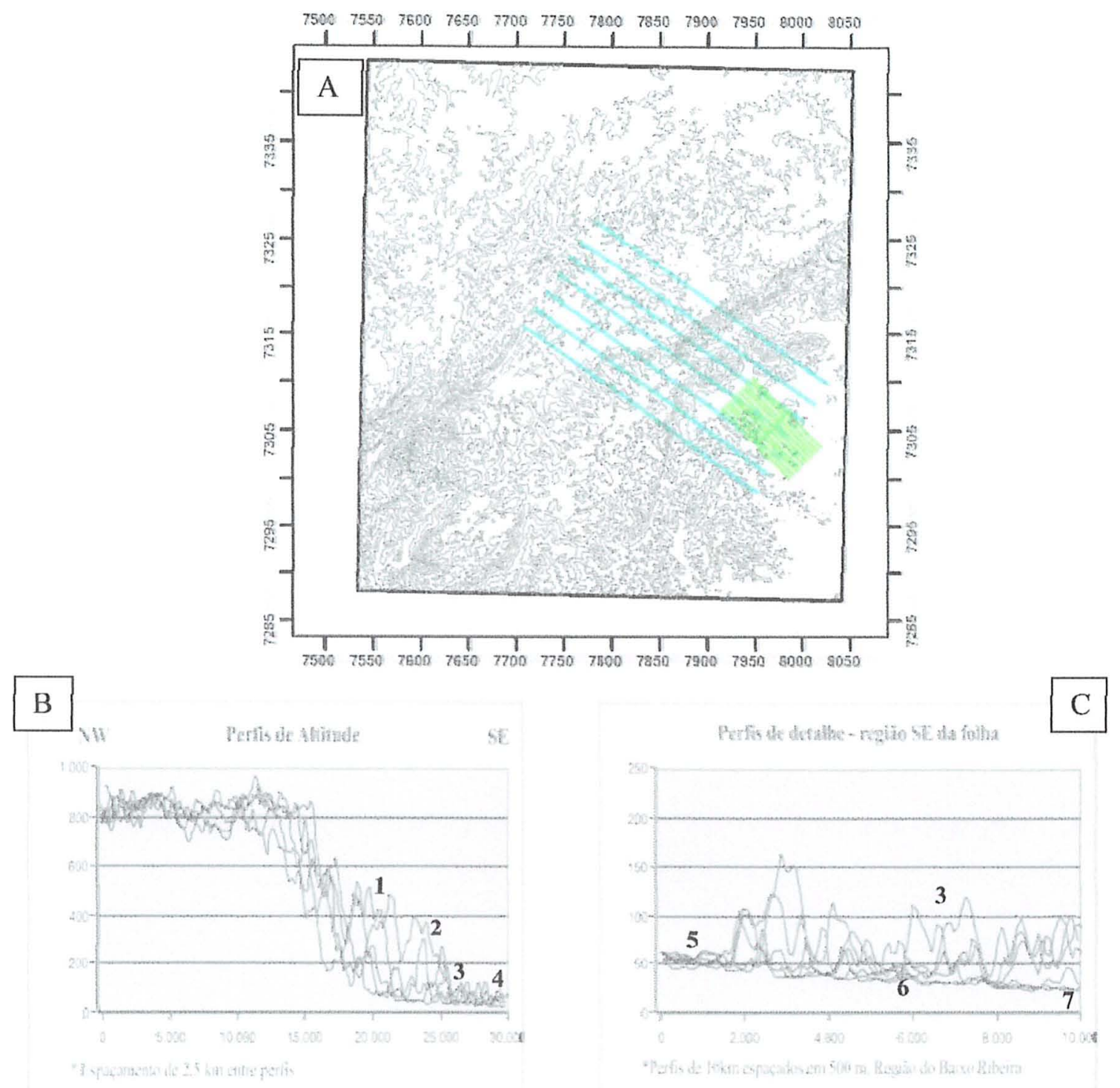

Figura 4. A. Localização dos perfis de altitude realizados na área. Em azul, B. Perfis de $30 \mathrm{~km}$ na direção NW-SE. Notar o Planalto Atlântico seguido da escarpa da Serra de Paranapiacaba. Mais a SE ocorrem 4 principais patamares. 1 - Por volta dos $450 \mathrm{~m}$. 2- Aproximadamente $350 \mathrm{~m}$. 3. Por volta de $100 \mathrm{~m}$. 4. Nível de base atual $<50 \mathrm{~m}$. Em verde C. Perfis de detalhe da região do Baixo Ribeira, na direção NW-SE. Observa-se o patamar dos $100 \mathrm{~m}$ (3), além dos prováveis níveis de base da bacia do Ribeira, equivalentes á porção 4 na figura 4b: 50m (5), 35m (6) e <25m - nível atual (7). 

Finalmente, somam-se ao conjunto de dados os resultados interpretados a partir do tratamento de isobases (figura 5). Foram interpretadas as estruturas que apresentam, segundo este método, maior controle sobre as drenagens da área. Observa-se que há o predomínio de estruturas NW-SE e NE-SW, o que já se esperava devido à predominância natural destas direções em meio às estruturas regionais. Entretanto, o método evidencia que estruturas de direção E-W e N-S também são responsáveis pelo controle local de algumas drenagens.

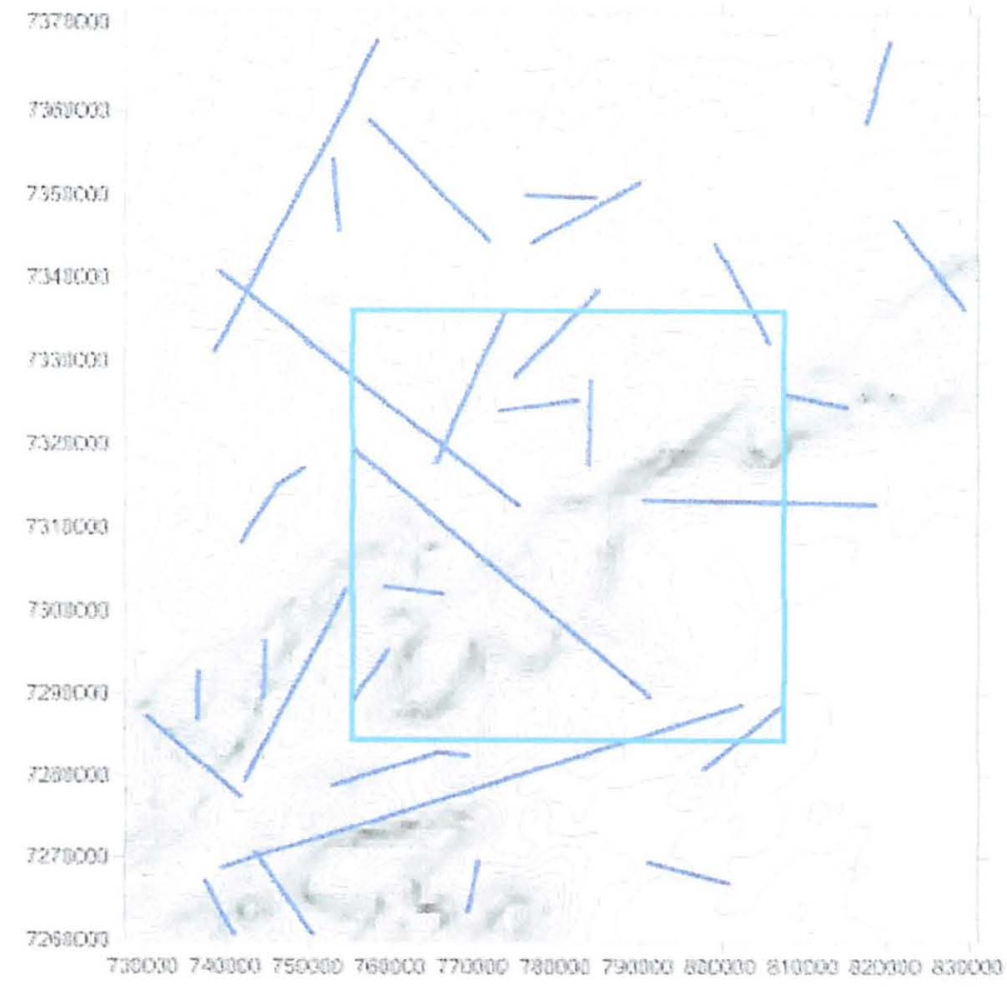

Figura 5. Resultados interpretados para o tratamento de isobases, com a área da folha Capão Bonito em destaque. As estruturas em azul são interpretadas a partir de quebras bruscas no resultado da interpolação das altitudes dos pontos de intersecção entre as drenagens e as linhas de cota.

Nota-se que a área em que foi aplicado o método das isobases em muito supera a da folha Capão Bonito. Isto ocorre porque o método relaciona a morfologia das drenagens - e de suas bacias hidrográficas - com a topografia. Desta forma, uma área restrita com um grande divisor de águas como a Serra de Paranapiacaba acabaria por trazer resultados não satisfatórios, já que não compreenderia as bacias hidrográficas regionais por inteiro, mascarando níveis de base locais e piorando a qualidade da interpretação. Para evitar isto, a área de amostragem foi ampliada para considerar as drenagens das duas principais bacias hidrográficas da região: a do rio Paranapanema a Norte, e a do rio Ribeira de Iguape, a sul. O resultado mostra ainda a grande quantidade de linhas de isovalores coincidentes com a região da Serra de Paranapiacaba, o que ocorre pelo desenvolvimento de drenagens obsequentes em sua escarpa.

Ainda observando a figura 5, ressalta-se a presença de estruturas NW-SE e NE-SW a norte, já no domínio da Bacia do Paraná. Isto evidencia que as estruturas do embasamento e do Alinhamento de Guapiara são importantes não apenas no domínio das rochas cristalinas do Planalto Atlântico, mas também nas movimentações ocorrentes na região da depressão Paranapanema. 



\section{Conclusões}

A aplicação de métodos de geomorfometria em dados de elevação SRTM - realização de conjuntos de perfis, extração de lineamentos - aliados ao método das isobases, forneceu dados sobre a geologia estrutural da área de estudo, além de apontar possíveis estruturas responsáveis pelas movimentações tectônicas recentes ocorridas na região.

Conforme o observado na figura 3, a região em questão apresenta um forte predomínio das estruturas de direção NW-SE. Ao longo destas fraturas se instalam diques de rocha básica de extensão quilométrica, que entrecortam a área de estudo. Este forte lineamento NW-SE é conhecido como Alinhamento de Guapiara e está associado à fase da abertura do Atlântico sul, contendo os diques de alimentação do grande magmatismo fissural básico durante o período juro-cretáceo da Bacia do Paraná.

Também muito frequentes são as estruturas de direção NE-SW. Estas estão associadas principalmente às foliações dominantes no terreno metamórfico da Faixa Ribeira, bem como às grandes estruturas de cisalhamento regional, predominantemente destrais, que existem na área como a falha dos Agudos Grandes.

Ambas as estruturas são evidenciadas pelo método das isobases na região da Bacia do Paraná, na porção $\mathrm{N}$ da folha, sugerindo que as movimentações nestes planos afetam as litologias sotopostas à Faixa Ribeira, além do Planalto Atlântico. Por fim, são observadas estruturas de direção E-W e N-S menores, interpretadas como um padrão de fraturamento ocorrido quando das reativações das estruturas maiores durante períodos recentes da historia geológica.

Os aglomerados de linhas de isovalores na faixa central da folha, com direção NE-SW foram interpretados como reflexo da proeminente escarpa da Serra de Paranapiacaba, com o desenvolvimento de drenagens obsequentes. Estas estruturas foram, portanto, descartadas do conjunto de lineamentos relacionados às movimentações recentes.

Finalmente, as conclusões deste trabalho corroboram dados de trabalhos pioneiros na região realizados por Melo et al. (1989), e Melo (1990) além de dados de campo ainda não publicados obtidos pelo Serviço Geológico do Brasil no ano de 2012. Segundo o observado, a interação das estruturas NW-SE e NE-SW é a responsável pelo controle efetivo do relevo da região. Evidencia-se isto principalmente na área do Baixo Ribeira, onde a foliação regional ocorre bastante verticalizada e com fortes feições de cisalhamento em maior grau metamórfico. Neste contexto, os blocos rochosos tendem a deslizar perpendicularmente aos planos de foliação e/ou planos de cisalhamento, posto que as estruturas e diques NW-SE os limitam.

Estas duas estruturas dominantes, aliadas ao clima úmido e quente da região, promovem a geração de feições como os morros arredondados em 'meia laranja' e o forte abatimento do relevo nas regiões do Baixo Ribeira e Graben de Sete Barras.

$\mathrm{Na}$ porção do Planalto Atlântico, estas estruturas condicionam escorregamentos, voçorocas e erosão diferencial, esta principalmente relacionada aos diques de basalto que podem ocorrer tanto em cristas, quanto em vales de rios.

\section{Agradecimentos}

Os agradecimentos vão ao CNPq, órgão financiador do projeto de mestrado ao qual este trabalho está vinculado. Ao Prof. Dr. Carlos Henrique Grohmann de Carvalho, coautor, por sua ajuda, tutela e discussões que em muito enriqueceram este artigo. Finalmente, aos amigos da CPRM - SP e do Instituto de Geociências que facilitaram a realização deste projeto através de idas a campo e do grande apoio científico em discussões sobre os tópicos referentes a este trabalho. 


\section{Referências Bibliográficas}

FILOSOFOV, V.P. Breaf Guide of morphometric methods in search of tectonic structures. Imprenta da Universidade de Saratov, Saratov,1960. (em russo).

GROHMANN, C. H.; RICCOMINI, C.; CHAMANI, M. A.C. 2011. Regional Scale Analysis of Landform Configuration with base-level (isobase) maps. Hidrology and Earth System Sciences (15) 1493-1504.MELO, M.S.; FERNANDES, L.A.; COIMBRA, A.M. \& RAMOS, R.G.N. 1989. O Graben (terciário?) de Sete Barras, Vale do Ribeira de Iguape, SP. Revista Brasileira de Geologia 19(2) 260-262.

MELO, M.S.; FERNANDES, L.A.; COIMBRA, A.M. \& RAMOS, R.G.N. 1989. O Graben (terciário?) de Sete Barras, Vale do Ribeira de Iguape, SP. Revista Brasileira de Geologia 19(2) 260-262.

MELO, M.S. Formação pariquera-Açu e depósitos correlacionados: sedimentação tectônica e geomorfogênese.Tese (Mestrado em geociências). Instituto de Geociências da Universidade de São Paulo, São Paulo, 1990.

Powell, J. W., 1875. Exploration of the Colorado River of the West and its tributaries. Explored in 1869, 1870,1871 , and 1872 under the direction of the secretary of the Smithsonian Institution. Government Printing Office, Washington.

RICCOMINI, C. O Rift continental do sudeste do Brasil. 1989. 304p. Tese (Doutoramento em geociências). Instituto de Geociências da Universidade de São Paulo, São Paulo, 1989.

ROSS, J.L.S. \& MOROZ, I.C. 1993. Mapa Geomorfológico do Estado de São Paulo. Material cartográfico 1:500.000 + monografia. Departamento de Geografia da Faculdade de Filosofia, Letras e Ciências Humanas da Universidade de São Paulo. 
ANEXO 1. MAPA GEOLÓGICO 




MAPA GEOLÓGICO DA FOLHA CAPÃO BONITO SG-22-X-B-III

Legenda

CENOZÓICO

Q2a Terracos

PALEOZÓICO

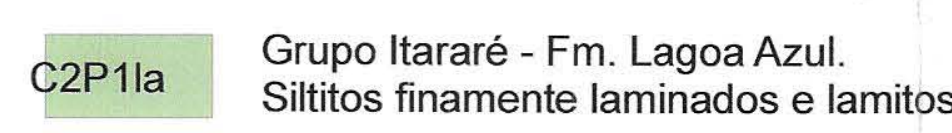

PROTEROZOICO

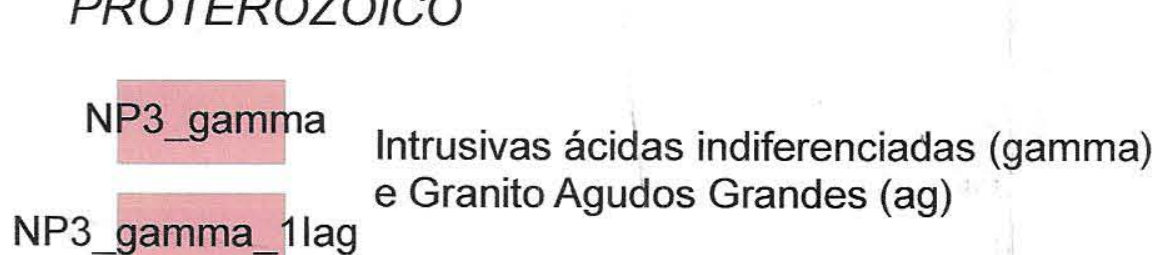

NP3_gamma_1lag

NP3ipp

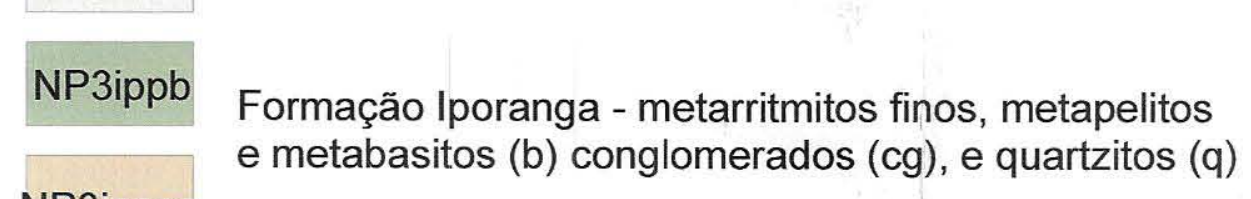

NP3ippcg

NP3ippq

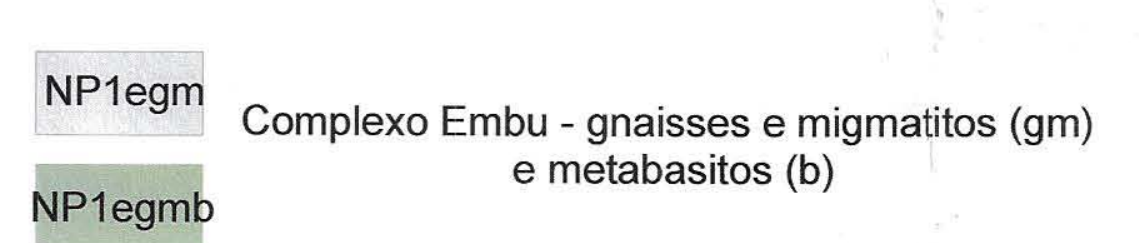

NP1egmb

MP1pi

MP 1pib Formaçăo Piririca- - metarrittmitos e básicas (b)

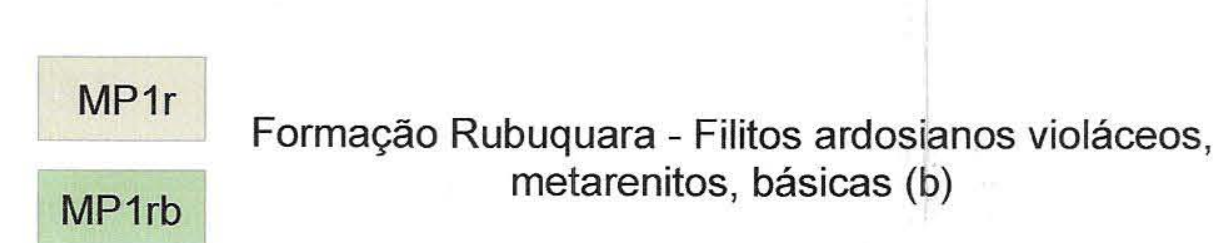

MPba

MPbos

MPbm

MPbp

MPbs

MPbs Formaçăo Bairro da Serra - Metacalcarentitos com acamamento
sedinentar preservado.

MPsap

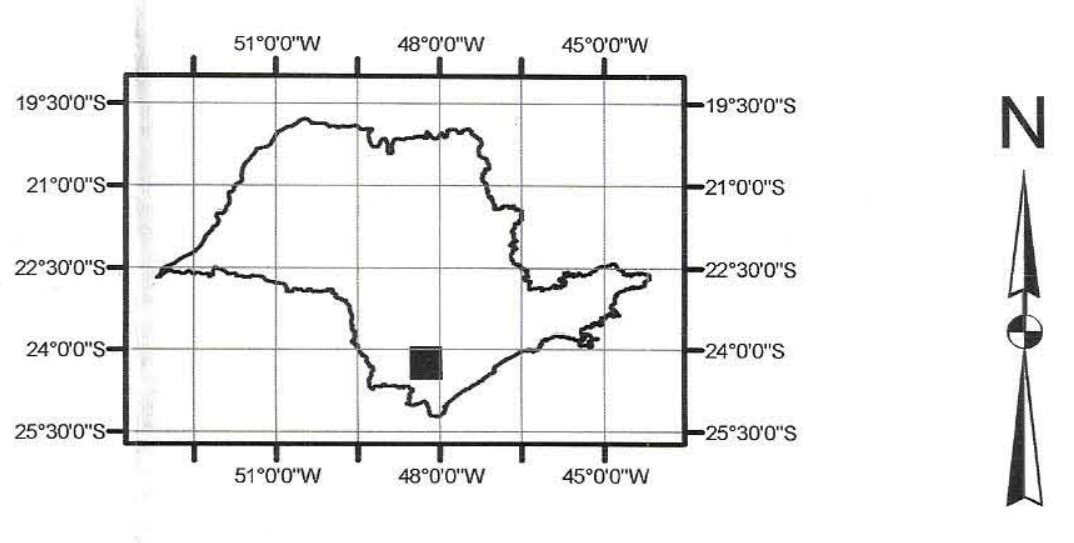

Lcalizaçăo da Folha Capão Bonito

\section{$1^{N}$}



ANEXO 2. MAPA MORFOESTRUTURAL 


\section{0}

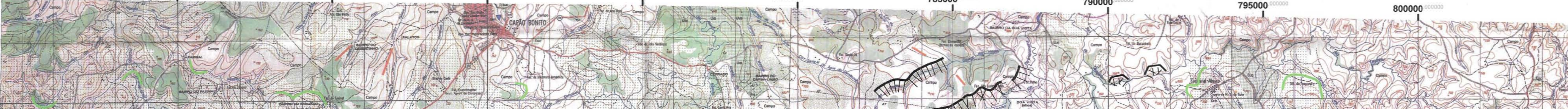

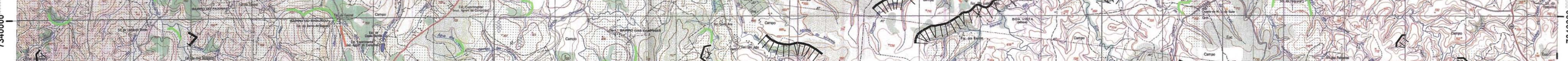

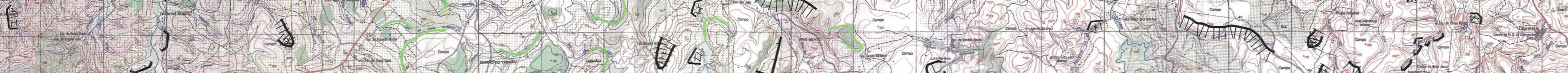

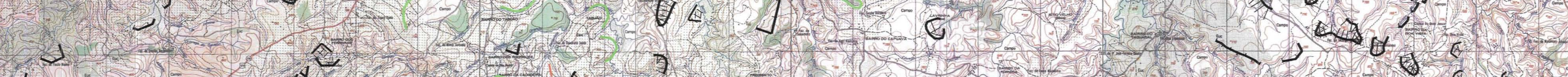

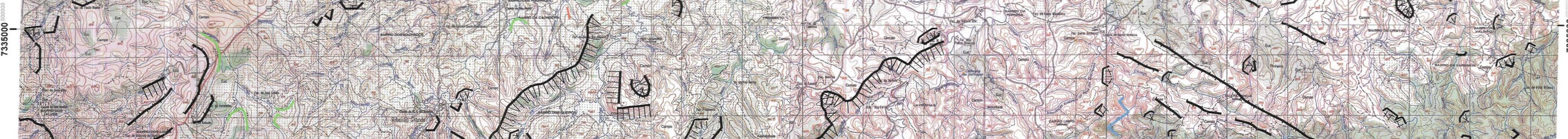

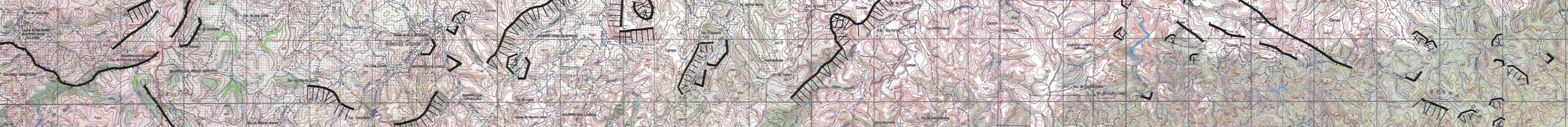


ANEXO 3.PUBLICAÇÕES 



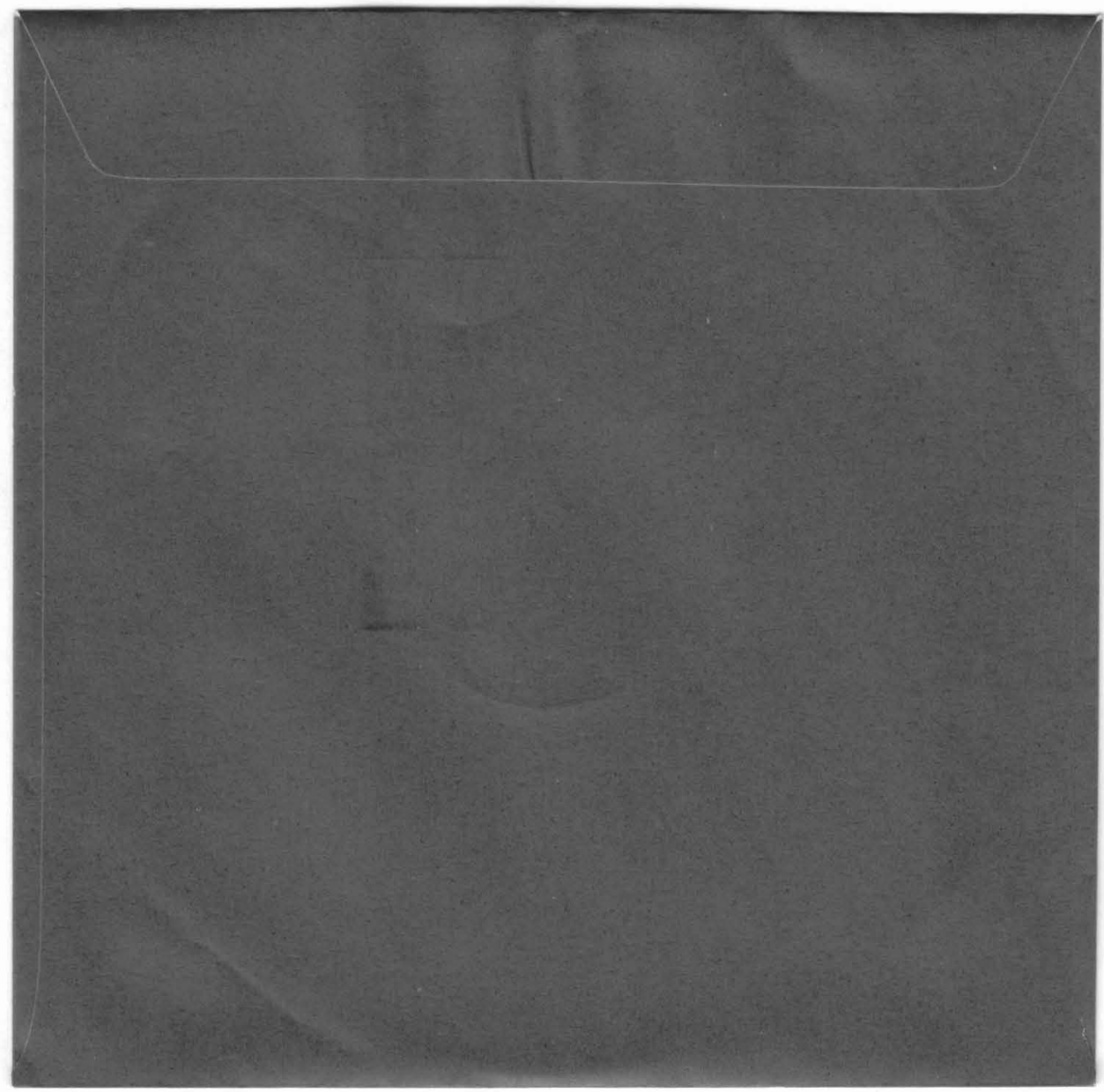

ANEXO 4. CD 


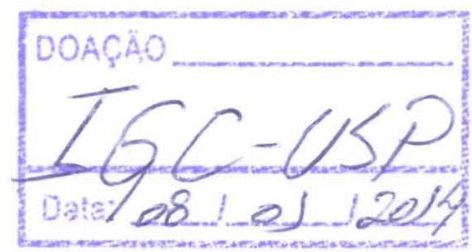


